


\section{EDITORIAL}

Caro leitor, esta edição especial do Journal of Sport Pedagogy and Research tem como propósito, analisar o tema do desporto de natureza, nas suas diversas perspetivas. Trata-se de uma área socioprofissional relativamente jovem, quando comparada com outras profissões do desporto e da educação física, apesar de ter surgido em Portugal, no sistema de ensino superior, há mais de duas décadas. Na realidade, o desporto de natureza é um subsetor que tem por base o setor do desporto, mas que poderá interligar-se a outros setores da sociedade, tais como, o ambiente, o turismo, a economia, a saúde e a educação. Deste modo, considerando que no atual momento, ainda não existe uma regulamentação clara que sustente o desenvolvimento responsável desta área e dos seus profissionais, importa deste modo, dar corpo a um conjunto de preocupações e temáticas de diferentes autores, com experiências e perspetivas também diversificadas, que pretendem contribuir para o enriquecimento do debate sobre o tema do desporto de natureza. Assim, o conjunto de estudos que compõem esta edição explora diversas dimensões de pesquisa, nomeadamente, a importância da formação, a sistematização das práticas físicas e desportivas, a problemática do subsetor, a avaliação dos locais de prática, a intervenção pedagógica, os fatores motivacionais da prática desportiva, a caracterização dos praticantes turistas e das experiências vivenciadas, a avaliação de percursos pedestres e de btt. Por fim, gostaríamos de agradecer a todos os autores e colaboradores o seu contributo nesta edição.

Dear reader, this special edition of the Journal of Sport Pedagogy and Research aims to analyse the theme of outdoor sport, in its various perspectives. It is a relatively young socio-professional area when compared to other professions in sport and physical education, despite having emerged in Portugal, in the higher education system, more than two decades ago. In reality, outdoor sport is a sub-sector that is based on the sport sector, but which may be interconnected with other sectors of society, such as the environment, tourism, economy, health and education. Thus, considering that at the present time, there is still no clear regulation that supports the responsible development of this area and its professionals, it is therefore important to give body to a set of concerns and themes of different authors, with experiences and perspectives that are also diversified, which intend to contribute to the enrichment of the debate on the theme of outdoor sport. In this sense, the set of studies that make up this edition explores different dimensions of research, namely, the importance of training, the systematization of physical and sports practices, the subsector's problems, the evaluation of practice places, pedagogical intervention, motivational factors sports practice, the characterization of practicing tourists and experiences, the evaluation of walking routes and mountain biking. Finally, we would like to thank all authors and contributors for their contribution to this issue.

Estimado lector, esta edición especial de la Revista de Pedagogía e Investigación del Deporte tiene como objetivo analizar el tema del deporte de la naturaleza, en sus diversas perspectivas. Es un ámbito socioprofesional relativamente joven en comparación con otras profesiones del deporte y la educación física, a pesar de haber surgido en Portugal, en el sistema de educación superior, hace más de dos décadas. En realidad, el deporte de naturaleza es un subsector que se basa en el deporte, pero que puede estar interconectado con otros sectores de la sociedad, como el medio ambiente, el turismo, la economía, la salud y la educación. Así, considerando que en la actualidad aún no existe una normativa clara que sustente el desarrollo responsable de esta área y de sus profesionales, es por tanto importante dar cuerpo a un conjunto de inquietudes y temáticas de diferentes autores, con experiencias y perspectivas que también se diversifican, que pretenden contribuir al enriquecimiento del debate sobre el tema del deporte de naturaleza. En este sentido, el conjunto de estudios que componen esta edición explora diferentes dimensiones de la investigación, a saber, la importancia del entrenamiento, la sistematización de las prácticas físicas y deportivas, la problemática del subsector, la evaluación de los lugares de práctica, la intervención pedagógica, los factores motivacionales la práctica deportiva, la caracterización de turistas practicantes y experiencias, la evaluación de rutas a pie y en bicicleta de montaña. Finalmente, nos gustaría agradecer a todos los autores y colaboradores por su contribución a este número.

Diretores editoriais Edição Especial Desportos de Natureza

Luís Carvalhinho e Carlos Mata 


\section{Diretor Editorial Edição Especial Desportos Natureza}

Luís Carvalhinho e Carlos Mata

Rui Resende (ISMAI)

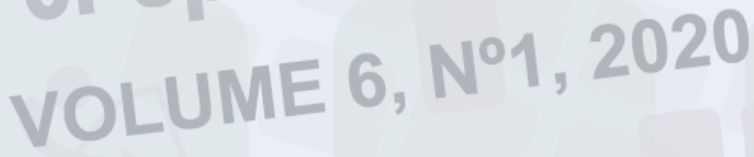

\section{Diretor Editorial Adjunto}

Hugo Sarmento (FCDEF-UC/CIDAF)

Adilson Marques (FMH-UL)

Paula Batista (FADE-UP)

\section{ISSN 2183-7783}

\section{Conselho Editorial}

Ágata Aranha (UTAD), Alcides Scaglia (UNICAMP), Antonino Pereira (ESEV-IPV), Carlos Zuluaga (Universidad de Caldas), Cecília Borges (Universidad Montreal), Tiago Sousa (FCDEF-UC), Galcemar Martins (UDESC), Hélder Lopes (UMA), José Rodrigues (ESDRM-IPSantarém), Juarez Nascimento (UFSC), Larissa Benites (UDESC), Larrisa Galati (UNICAMP), Miguel Saavedra (UDC), Nuno Pimenta (IPMAIA), Paula Batista (FADEUP), Ricardo Lima (IPVC), Roberto Hernández (Universidad Autonoma), Rui Gomes (Universidade do Minho), Samuel Neto (UNESP), Sergio Ibanez (UNEX), Susana Franco (ESDRMIPSantarém), Vitor Ferreira (FMH-UL).

\section{Edição}

Sociedade Científica de Pedagogia do Desporto

\section{Capa}

Mariana Moreira

ISSN 1647-9696 


\title{
Caminhos para a Formação e Intervenção em Desporto de Natureza
}

\author{
Luís Carvalhinho $^{1,2}$, Paulo Rosa ${ }^{1,2}$
}

${ }^{1}$ Escola Superior de Desporto de Rio Maior - Instituto Politécnico de Santarém (ESDRM-IPS)

${ }^{2}$ Centro de Investigação, Desenvolvimento e Inovação em Turismo (CITUR)

\begin{tabular}{ll}
\hline $\begin{array}{l}\text { Palavras-chave } \\
\text { Formação; } \\
\text { Intervenção } \\
\text { Profissional; } \\
\begin{array}{l}\text { Desporto de } \\
\text { Natureza. }\end{array}\end{array}$ & $\begin{array}{l}\text { RESUMO: } \\
\text { Os processos de formação dos profissionais de desporto de natureza, o domínio dos } \\
\text { diversos saberes, a qualidade da intervenção técnica, pedagógica e científica nas } \\
\text { diferentes atividades, a salvaguarda das questões de segurança e gestão do risco, as } \\
\text { boas práticas associadas à sustentabilidade e ao desenvolvimento humano são, entre } \\
\text { outras, algumas das áreas que podem (e devem) contribuir, para o desenvolvimento } \\
\text { desta área. Considerando este propósito e tendo por base uma síntese de investigação } \\
\text { aplicada, bem como, a acumulação de duas décadas de experiência, apresentamos o } \\
\text { nosso entendimento sobre o que consideramos relevante para o caminho a percorrer, } \\
\text { no contexto da formação e da intervenção em desporto de natureza. }\end{array}$ \\
\hline $\begin{array}{l}\text { Keywords } \\
\text { Training; } \\
\text { Professional } \\
\text { Intervention; } \\
\text { Nature-Based Sport. }\end{array}$ & $\begin{array}{l}\text { Paths for training and intervention in nature-based sport } \\
\text { ThSTRACT: }\end{array}$ \\
$\begin{array}{l}\text { Types of knowledge, the quality of technical, pedagogical and scientific intervention in } \\
\text { different activities, the safeguarding of safety and risk management issues, the good } \\
\text { practices associated with sustainability and development are, among others, some of } \\
\text { the areas that can (and should) contribute to the development of this area. Considering } \\
\text { this purpose and based on a synthesis of applied research, as well as the accumulation } \\
\text { of two decades of experience, we present our understanding of what we consider } \\
\text { relevant for the way to go, in the context of training and intervention in nature-based } \\
\text { sport. }\end{array}$
\end{tabular}




\section{Caminhos para a formação e intervenção em desporto de natureza}

O caminho para o sucesso, em sentido lato, normalmente assenta em três grandes questões: Onde estamos (presente)? Onde queremos chegar (futuro)? Por onde queremos ir (caminho)? Aliás, estas devem ser também, três regras fundamentais para orientar as nossas vidas.

Assim, ao abordar a temática da formação (inicial e ao longo da vida) e da intervenção (pedagógica e profissional) em desporto de natureza, optámos por fazê-lo, naturalmente, através dessa forma. Fizemos uma pequena retrospetiva sobre o tema da formação e as suas principais mudanças ao longo do tempo, destacando também algumas organizações de referência, bem como, um conjunto de estudos realizados no domínio do desporto de natureza que considerámos estruturantes para o desenvolvimento desta temática.

\section{Onde estamos (presente)?}

De modo a enquadrar minimamente a situação atual, foi necessário fazer uma pequena retrospetiva. A formação inicial no contexto do desporto de natureza, teve início em Portugal, no ano letivo de 1999/2000, na Escola Superior de Desporto de Rio Maior, do Instituto Politécnico de Santarém. Nessa fase, o curso de licenciatura designava-se por "Animação Desportiva, Recreação e Lazer". A realidade social nessa época, caracterizava-se por uma necessidade crescente de ocupação dos tempos livres com incidência nas atividades de animação desportiva, realizada em espaços urbanos, mas numa lógica de recreação e lazer do público-alvo. Tratava-se de uma nova abordagem às atividades físicas e desportivas, que criassem alguma rutura em relação ao desporto mais convencional. Não existia ainda, portanto, uma relação clara (e regulamentada) entre o desporto e o ambiente, nem entre o desporto e o turismo (animação turística), como atividade socioprofissional. Mais tarde, em 2004/2005, a mesma licenciatura passou a designar-se por "Desporto de Natureza e Turismo Ativo" (DNTA), mantendo-se até à presente data, considerando uma alteração de paradigma. A maioria dos locais de prática procurados pelas pessoas passaram a ser os espaços naturais e a importância que o crescimento da animação turística trouxe ao mercado turístico nacional, foi determinante, enquanto fonte de rendimento para muitos profissionais e respetivas organizações. Nestas duas últimas décadas e no contexto do DNTA, têm surgido diversas ofertas formativas no âmbito do Ensino Superior, quer por parte das Universidades quer por parte dos Institutos Politécnicos. Recentemente constituída (2015), a "Rede de Escolas com Formação em Desporto do
Ensino Superior Politécnico Público" (REDESPP), é composta por 14 Escolas de âmbito Nacional, tendo criado por sua vez, um grupo de trabalho (representado por 10 Escolas com oferta formativa na área), com o propósito de se debruçar sobre os processos de formação na área do desporto de natureza.

Nos últimos anos, o subsetor do DNTA tem vindo também a modificar o seu paradigma, i.e., trata-se de um modelo atualmente mais dinâmico, com interrelações constantes entre diversos setores de atividade. Segundo Carvalhinho e Rosa (2014), o "Modelo de Análise do subsetor DNTA" abrange os setores do Desporto, Educação, Ambiente, Turismo, Economia e Saúde. Isto significa que, em termos de formação de profissionais, devem ser acautelados os conhecimentos e as competências necessárias para intervir com qualidade e responsabilidade nestes setores. Estamos, portanto, na presença de uma formação e "profissão" mais abrangente (híbrida no campo das possibilidades), por um lado, mas por outro, com tendência para ser mais especializada (de acordo com as opções de cada um e exigência de cada atividade). Em termos de investigação, atualmente, é possível encontrar diversos estudos focados na temática da formação e da intervenção em desporto de natureza (Carvalhinho, 2006; Carvalhinho, Sequeira, Serôdio-Fernandes, \& Rodrigues, 2010; Silva, Silva, \& Carvalhinho, 2013; Carvalhinho, Rosa, Rodrigues, \& Nunes, 2015). É consensual e fundamental que, as práticas assentem na qualificação dos recursos humanos envolvidos e no seu aperfeiçoamento, sendo indispensável potencializá-los, nomeadamente, através de uma oferta formativa direcionada e estruturada em diferentes níveis de qualificação, responsabilidade e autonomia. Para identificar e compreender algumas das competências profissionais mais valorizadas em diversos estudos, Carvalhinho (2015), destacou algumas competências-chave, nomeadamente, as questões de segurança e socorro, as competências técnicas e pedagógicas associadas à avaliação e prescrição, ao conhecimento do meio, à comunicação e às boas práticas profissionais.

Uma das áreas de competência que distinguem os técnicos de desporto de natureza de outros profissionais da área do desporto, mais convencionais, é o "terreno de jogo". Isto significa que os 1 ocais de prática - espaços naturais, acarretam um grau de incerteza constante e mais complexo de gerir, pois as variáveis são imensas e a mudança das condições de prática pode ocorrer muito rapidamente. Daí, a necessidade efetiva em adquirir a competência para avaliar esses espaços naturais, de modo a conduzir as atividades de forma adequada e segura para todos (Carvalhinho, Rosa, \& Gomes, 2015; Carvalhinho, Rodrigues, \& Rosa, 2015). Ainda na relação entre o desporto e o ambiente, deve ser 
valorizada a educação ambiental, através do conhecimento e da utilização de códigos de conduta apropriados, inerentes à conservação da natureza e às áreas protegidas, onde se deve privilegiar a riqueza das experiências vivenciadas (Ajiboyea \& Olatunduna, 2010; Ferreira, 1998; Jensen \& Schnack, 1997; Rosa \& Carvalhinho, 2012).

O subsetor DNTA tem vindo a caminhar, devagar, no sentido de promover a imagem dos destinos turísticos, também aliada à melhoria dos serviços e produtos relacionados com a animação turística. Relembramos que a tutela da área do Ambiente, i.e., o "Instituto da Conservação da Natureza e das Florestas" (ICNF, I.P.), em tempos (2002), decidiu criar a necessidade para a construção das "Cartas de Desporto de Natureza", com o propósito de dispor de um instrumento de gestão para as Áreas Protegidas (AP). Apenas duas levaram os trabalhos a "bomporto". Neste caso, o "Parque Natural das Serras de Aire e Candeeiros" (PNSAC) e o Parque Natural de Sintra-Cascais" (PNSC). Estes "territórios" (AP), carecem de um planeamento efetivo e de uma coordenação eficaz, que permita um processo participativo, por diferentes intervenientes, entre eles, os stakeholders e os cidadãos em geral. Infelizmente, ainda não é uma realidade de abrangência nacional, o que prejudica seriamente, o desenvolvimento sustentável das regiões e o desenvolvimento humano (Rosa, Carvalhinho, \& Soares, 2016; Rosa, Carvalhinho, \& Soares, 2017; Silva \& Carvalhinho, 2017).

A literatura também é consensual, quando se refere às atividades de elevada complexidade e risco acrescido, recomendando frequentemente, que os profissionais desta área devem possuir formação especializada e devidamente certificada (DECO, 2008; Silva, Sousa, Lopes, \& Lopes, 2000; Silva, et al., 2013). Assim, o domínio da área da segurança e gestão do risco tem sido recomendada por diversos autores, devendo ser obrigatório em qualquer processo de formação, principalmente, quando se enquadram crianças e jovens em idade escolar (Almeida \& Silva, 2013; Beedie, 2013; Carvalhinho, Frazão, \& Moutão, 2013; Dougherty, 1998; Priest \& Gass, 1997). Nessa sequência, e considerando também a importância das normas internacionais (p.e., ISO 31000, 2018; ISO 31010 , 2019) e a sua adaptação ao desporto de natureza, outros estudos têm surgido e contribuído para a tentativa de prevenir e mitigar os acidentes (Almeida \& Silva, 2013, Gama \& Carvalhinho, 2014; Mata \& Carvalhinho, 2020). A identificação dos fatores de risco e das lesões desportivas (Carvalhinho, Mata, \& Rosa, 2018a), a par da avaliação do risco através de técnicas de avaliação específicas (ISO 31010, 2019), têm despertado também o interesse da investigação nos últimos anos, na área do desporto de natureza (Carvalhinho, Mata, \& Rosa, 2018b; Carvalhinho, Mata, \& Rosa, 2019).

\section{Onde queremos chegar (futuro)?}

Considerando o histórico e a juventude desta área no nosso país e, olhando para o trabalho já realizado por diversos atores e organizações, é emergente perspetivar uma futura profissão em desporto de natureza, que carece ainda de regulamentação ajustada por parte do Governo Português. No nosso entender, trata-se de uma nova profissão que deve emergir e consubstanciar-se na área do desporto, uma vez que é necessária qualificação própria para intervir no planeamento, enquadramento e avaliação de atividades físicas e desportivas, mas em cooperação com outros setores, nomeadamente com o ambiente e turismo. Na ausência desta regulamentação (da profissão), o subsetor DNTA tenderá a desenvolverse de forma anárquica e descoordenada, o que poderá levar a muitos outros problemas, tais como, a falta de qualificação dos profissionais, a proliferação de empresas sem os requisitos mínimos da qualidade desejada, a concorrência desleal, o aumento de acidentes por incumprimento das normas de segurança, a fraca qualidade dos produtos e serviços prestados, a insatisfação dos clientes, a má imagem dos destinos turísticos do país, e por conseguinte, a insustentabilidade do subsetor DNTA.

Deste modo, parece-nos particularmente importante, destacar a sustentabilidade, como ideia-chave a considerar no presente e no futuro-próximo, compreendendo as suas implicações na formação e na intervenção do desporto de natureza.

\section{A sustentabilidade na formação e na intervenção em desporto de natureza}

Apesar das múltiplas interpretações de "sustentabilidade" (Lugg, 2007). estas têm em comum, a inter-relação entre fatores ambientais, económicos e sociais. É por estes motivos que a reflexão sobre a sustentabilidade e o desenvolvimento humano se torna fundamental quando pensamos nestes desportos, e no seu desenvolvimento sustentável, como objetivo a alcançar por todos (Rosa \& Carvalhinho, 2012). Portanto, tentaremos identificar aspetos do presente e traçar linhas orientadoras para o futuro e, por conseguinte, para a formação daqueles que têm intervenção nestes contextos.

Dimensão Ambiental: As alterações climáticas e educação outdoor. Nesta dimensão, a sustentabilidade refere-se ao potencial de longevidade dos sistemas ecológicos e das comunidades, balançando-o com as influências e impactos causados pelas mesmas. A partir do momento em que são os recursos naturais os principais "palcos" de prática desportiva e que são estes que definem o limite (a par da imaginação humana) para a ação desportiva, esta ligação íntima 
merece, no presente e no futuro, a devida reflexão por académicos e profissionais.

\section{As alterações climáticas}

As alterações climáticas colocam-se como um dos assuntos que mais tem ocupado as agendas governativas a nível mundial. Neste campo, num passado relativamente recente, Buckley, Gretzel, Scott, Weaver, e Becken (2015) refletiram sobre as principais tendências do turismo a nível mundial. Entre estas, estavam as consequências económicas, sociais e ambientais causadas pelo aquecimento gradual do nosso planeta e os eventos meteorológicos extremos que se têm vindo a verificar. Embora controverso, o assunto das alterações climáticas não deve ser estranho aos setores do deporto e do turismo (Scott, Hall \& Gössling, 2019). Aspetos como o aumento da temperatura continental global, a subida do nível do mar ou o aumento da temperatura dos oceanos poderão provocar efeitos nefastos sobre os principais recursos de prática desportiva e, por conseguinte, dos próprios destinos turísticos. Atividades como o mergulho recreativo que assentam sobretudo na observação e interpretação da diversidade biológica marinha (Sato, Nanami, Bayne, Makino \& Hori, 2020), ou as atividades de inverno como o Esqui (Steiger, Scott, Abegg, Pons \& Aall, 2019), são alguns exemplos de práticas que provavelmente sofrerão com as mudanças no clima. Estas mudanças, espectáveis perante as alterações climáticas que se preveem, colocam desafios aos profissionais que desempenham funções em organizações que promovem estas atividades.

\section{A educação outdoor}

Algumas evidências da investigação científica têm revelado indícios positivos sobre a adoção de comportamentos pela experiência e pela vivência de determinadas situações e em determinados contextos sociais. As práticas de educação outdoor tem vindo a revelar algumas evidências efetivas (Rosa \& Carvalhinho, 2012; Sharma-Brymer, Gray \& Brymer, 2018), embora, nem sempre seja claro em que medida e magnitude, o efeito educativo, se transfere para a ação (Prince, 2016).

$\mathrm{Na}$ realidade, os técnicos que têm por função ensinar e monitorizar este tipo de atividades, podem ser vistos como modelos sociais, com responsabilidade ao nível da inclusão, de estratégias de sensibilização ambiental e de aprendizagem. Verifica-se, assim, uma ligação relevante com o setor educacional, sobretudo no domínio da educação Outdoor (Becker, 2010; Kos, 2010; Light, 2006; Zmudy, CurtnerSmith, \& Steffen, 2009). Quer o desempenho dos técnicos como modelos e mentores, quer o desenho das ações, carecem de princípios teóricos associados ao conhecimento pedagógico, em especial, aquele suportado na teoria da aprendizagem social, porque embora o reconhecimento efetivo de barreiras à participação e à adoção de comportamentos seja evidente (Kollmuss \& Agyeman, 2002), também um conjunto de abordagens metodológicas, assentes em principio teóricos e/ou resultados empíricos se tem revelado coerentes (Jensen \& Schnack 1997; Rosa \& Carvalhinho, 2012). Existe, portanto, uma tendência visível para a adoção de metodologias de ensino e aprendizagem mais ativas e participativas, considerando que existem também novos desafios para as gerações mais novas.

Dimensão Económica: a ligação com o turismo e o desenvolvimento tecnológico. É inegável a importância dos desportos de natureza e aventura no setor turístico e na sua capacidade de promover alterações nas estruturas socioeconómicas nos destinos. Do ponto de vista socioeconómico, existem fatores que perturbam um desejado equilíbrio e estabilidade dos mercados. Buckley et al. (2015) na sua reflexão sobre as principais tendências mundiais no turismo, apontam o aumento do preço dos combustíveis, os conflitos geopolíticos e o desenvolvimento tecnológico, como fatores a ter em conta, e que, estando ou não diretamente relacionados com a economia, irão certamente influenciar o futuro. Os recentes acontecimentos relacionados com a Pandemia COVID-19, p.e., fizeram relembrar o quão sensível é a economia turística a fatores conjunturais, que rapidamente e sem aviso, influenciam a procura. Mas se, a envolvente externa dos negócios condiciona o desenvolvimento, então a capacidade para agir na envolvente interna surge como a capacidade instalada para combater esses problemas. O domínio técnico de diferentes áreas da gestão por parte dos técnicos e responsáveis de organizações privadas, certamente potenciará a capacidade de reação à instabilidade externa que hoje vivemos e que certamente continuaremos a viver. Parte desta capacidade prende-se com o desenvolvimento tecnológico. Com este, muda o comportamento dos consumidores, a forma como acedem à informação e os instrumentos que utilizam para consultar, escolher ou recomendar, e o turismo de natureza e aventura não é exceção (CBI, 2020). As denominadas gerações " $Y$ " e " $Z$ " ocupam um lugar muito importante nos novos segmentos de turistas que viajam pela aventura. Indivíduos "tecnológicos", têm encontrado no mercado opções à sua medida, com o crescimento de aplicações móveis, redes sociais que permitem a partilha de experiências, blogs especializados ou vídeos gravados por profissionais e aventureiros que influenciam as expetativas e por isso condicionarão as experiências futuras (CBI, 2020). Diversas organizações, já utilizam tecnologias avançadas de realidade virtual, p.e., para simular a presença em espaços e o desempenho nas atividades. 
Por último, importa realçar que os públicos relacionados com o turismo de aventura têm vindo a mudar do ponto de vista demográfico e o mercado ganha reputação para novos investimentos (CBI, 2020). Simultaneamente, novos e cada vez mais arrojados e originais produtos surgem no mercado, aumentando a diversidade e o potencial de escolha e a capacidade criativa de lidar com a concorrência e de perceber e reagir às alterações externas, que deverão ditar o futuro de cada organização.

A título de exemplo, podemos observar as tendências dos novos tempos, surgindo cada vez mais, os Tours Self-Guided, com maior expressão nos percursos pedestres e de bicicleta. Traduzem-se por viagens que pretendem garantir maior segurança e autonomia aos seus participantes e o usufruto de uma maior liberdade. Neste caso, serão necessárias algumas tecnologias, tais como, um GPS e um Smartphone, com acesso à Internet e respetivas apps (aplicações).

Dimensão Social: do bem-estar individual ao desenvolvimento local. De acordo com Mackenzie (2018), os desportos de natureza tem vindo a ser entendidos como práticas que promovem diversos aspetos hedónicos e eudemónicos do bem-estar: i) facilitam sentimentos de conexão à natureza; ii) promovem benefícios físicos e mentais associados à atividade física; iii) promovem oportunidades de superação e experiência únicas; iv) aumentam a autoeficácia, a resiliência; v) potenciam a estimulação cognitiva; vi) promovem a autodeterminação; vii) estimulam a conexão social. Os estudos de Light (2006) e de Sandell e Öhman (2010), na área da construção pessoal e social do individuo, também reforçam esta tendência.

Estas práticas, embora assentes numa perspetiva experiencial, já ultrapassam largamente a experiência única e isolada. Os praticantes não profissionais, procuram experiências duradouras, incluindo nas suas rotinas de prática desportiva, o complemento com o treino das aptidões físicas, a alimentação ou a aquisição de equipamentos especializados. Em alguns casos, este fenómeno denominado de Serious Leisure (Stebbins, 2007) já se sobrepõe ao conceito de lifestyle que tende a caracterizar os envolvidos nestes desportos (Rahikainen, 2020).

Por último, extravasando a esfera individual, sendo estas atividades uma importante opção de lazer e turismo praticadas em contextos predominantemente rurais, tem vindo a demonstrar a sua importância na revitalização das culturas e do conhecimento local e tradicional, já que este sentido de descoberta e de vivência cultural faz parte integrante das intenções de viagem e visita dos diversos interessados (CBI, 2020).

Neste caso, é possível observar em Portugal, exemplos de boas práticas, nomeadamente, o crescimento de eventos e produtos desportivos, e de animação turística, associados à valorização do território, do património histórico, cultural e humano. Vejamos por exemplo, os projetos relacionados com os itinerários das Grandes Rotas, nas suas vertentes de prática pedestre, bicicleta, canoagem e equestre. Nesta situação, os serviços disponibilizados pelo tecido empresarial, em particular, associados à indústria do desporto e às Empresas de Animação Turística (EAT), tendem a ser cada vez mais especializados e de melhor qualidade, contribuindo desse modo, para o bem-estar das pessoas e para o desenvolvimento local, das regiões e do país.

\section{Por onde queremos ir (caminho)?}

A formação de profissionais de desporto de natureza (DN), seja ela inicial ou numa perspetiva de formação (contínua) ao longo da vida, deverá considerar as seguintes dimensões: Técnico-Científica; Pedagógica, Ambiental, Económica e Social.

Para orientar o "caminho" a percorrer e, em jeito de síntese, recomenda-se o seguinte:

\section{Dimensão Técnico-Científica}

- Conhecimentos e competências técnicas específicas (habilidades motoras), que permitam dominar de forma autónoma, a complexidade, as diferentes condições e níveis de prática desportiva;

- Conhecimentos e competências sobre as normas e procedimentos de segurança, avaliação e gestão do risco, prevenção de acidentes e primeiro socorro;

- Conhecimentos científicos nos diferentes domínios (p.e., biomecânica, fisiologia, psicologia, pedagogia, gestão, sociologia, etc.), que permitam planear, avaliar, controlar e prescrever adequadamente, e de forma responsável, assente na evidência científica e nas boas práticas.

\section{Dimensão Pedagógica}

- Conhecimentos sobre a relação e a intervenção pedagógica em DN, nas vertentes da formação, da recreação e do rendimento desportivo;

- Conhecimentos de planeamento estratégico e operacional em DN, considerando as diferentes tipologias de atividades (p.e. atividade pontual; multiatividades e ciclos concentrados de atividades), nos seus diferentes contextos: educativo-formativo, desportivo, recreativo e turístico;

- Conhecimentos sobre as principais funções e técnicas de intervenção pedagógica e profissional em $\mathrm{DN}$;

- Competências de liderança, gestão de grupos, tomada de decisão e resolução de problemas em DN; - Competências de avaliação de recursos e espaços de prática, na relação com o sucesso e com a segurança das atividades;

- Competências de avaliação diagnóstica e prescrição pedagógica, de habilidades motoras em DN; 
- Conhecimentos sobre as técnicas, metodologias e estilos de ensino e aprendizagem em DN e suas implicações na eficácia pedagógica e sucesso profissional;

- Conhecimento sobre o comportamento reflexivo e os códigos de conduta dos profissionais de $\mathrm{DN}$;

- Competência pedagógica e humana para agir como modelo, com a capacidade para influenciar os outros, para a adoção de comportamentos sociais, éticos e ambientalmente responsáveis;

\section{Dimensão Ambiental}

- Conhecimentos sobre as alterações climáticas e as suas consequências sobre os setores associados ao $\mathrm{DN}$, permitindo uma visão crítica sobre o problema; - Competências de autorreflexão sobre o comportamento humano, na sua relação com a natureza e os recursos naturais nas diferentes esferas da vida (desde a prática desportiva aos hábitos alimentares);

- Conhecimento sobre a relação entre as Atividades desportivas versus Impactes ambientais versus Mitigação;

- Conhecimento sobre o funcionamento das organizações desportivas e turísticas e a forma como a gestão ambiental poderá fazer parte integrante desses próprios sistemas.

\section{Dimensão Económica}

- Conhecimentos e competências de análise crítica sobre a envolvente externa, em especial sobre as alterações económicas, sociais e tecnológicas que influenciam os mercados;

- Competências que estimulem a criatividade e a capacidade de desenvolvimento de novos conceitos, modelos de negócio, serviços e produtos relacionados com o DN;

- Conhecimentos de liderança e capacidades técnicas de gestão que permitam a intervenção em vários domínios (p.e. marketing; desenvolvimento de produto);

- Competências que visem a adaptação à evolução tecnológica e, a compreensão das suas capacidades, na perspetiva da sua função e do seu funcionamento; - Conhecimentos atualizados sobre a indústria do desporto, do turismo e da saúde, o perfil dos consumidores e os principais critérios de segmentação dos mercados relacionados com o subsetor DNTA.

\section{Dimensão Social}

- Conhecimento sobre questões de saúde pública, e as alterações nos padrões sociais que caracterizam a visão sobre a saúde e o bem-estar físico e mental; - Conhecimento sobre os fatores psicológicos e sociais associados aos desportos de natureza, e a sua relação com o bem-estar pessoal e social;
- Conhecimento sobre os valores culturais das comunidades rurais e a sua importância para o desenvolvimento social e económico dessas regiões e, por conseguinte, a capacidade para integrar estes aspetos no desenvolvimento de programas de desporto, lazer, turismo e bem-estar.

\section{Nota Final}

Somos da convicção que, um profisssional de qualidade, deve conseguir aliar a sua formação à experiência profissional, e que esta, por sua vez, alimente a necessidade contínua de atualizar os seus conhecimentos e as suas competências. Deste modo, este profissional, deverá possuir um perfil de competências que assente numa sólida formação técnica, pedagógica e científica, considerando as especificidades e a complexidade dos desportos de natureza. $\mathrm{O}$ sentido de responsabilidade individual e o compromisso coletivo, a ética e a deontologia profissional, deverão ser também, valores constantes ao longo da vida.

Como alguém dizia, "o caminho faz-se caminhando". Por isso, conscientes que ainda temos muito caminho pela frente, mas também cientes de que existe caminho feito, acreditamos que estamos no caminho certo.

\section{Referências}

Ajiboyea, J., \& Olatunduna, S. (2010). Impact of some environmental education outdoor activitieson nigerian primary school pupils' environmental knowledge. Applied Environmental Education \& Communication, 9(3), 149-158. https://doi.org/10.1080/1533015X.2010.510020

Almeida, M., \& Silva, F. (2013). Matriz de dados para aplicação da gestão do risco em animação turística. In M. Almeida (Ed.), Turismo e desporto na natureza. Congresso Internacional da Montanha (pp. 221-238). A. D. A. Desnível \& ESHTE.

Becker, P. (2010). Encountering, experiencing and exploring nature in education. Eslovénia: European Institute for Outdoor Adventure Education and Experiential Learning.

Beedie, P. (2013). Managing risk: Analysis of adventure tourism in Britain. In, M. Almeida (Ed.), Turismo e desporto na natureza. Congresso Internacional da Montanha (pp. 201-220). A. D. A. Desnível \& ESHTE.

Buckley, R., Gretzel, U., Scott, D., Weaver, D., \& Becken, S. (2015). Tourism megatrends. Tourism Recreation Research, 40(1), 59-70. 
https://doi.org/10.1080/02508281.2015.1005942

Carvalhinho, L. (2006). Os técnicos e as actividades de desporto de natureza - Análise da formação, funções, e competências profissionais. (PhD), Universidade de Trás-os-Montes e Alto Douro, Vila Real.

Carvalhinho, L., Sequeira, P., Serôdio-Fernandes, A. \& Rodrigues, J. (2010). A emergência do sector do desporto de natureza e a importância da formação. EFDeportes, Revista Digital - Buenos Aires, 14(140). https://www.efdeportes.com/efd140/desportode-natureza-e-formacao.htm

Carvalhinho, L., Frazão, H., \& Moutão, J. (2013) The safety of young adolescents in nature-based sports. Risk perception and prevention. Atención Primária, 45, 27.

Carvalhinho, L., \& Rosa, P. (2014). Enquadramento do subsetor do Desporto de Natureza e Turismo Ativo. In, L. Carvalhinho (Eds.), Desporto de natureza e turismo ativo. Contextos e desenvolvimento (pp. 1-12). ESDRM-IPS, Rio Maior.

Carvalhinho, L., Rosa, P., \& Gomes, F. (2015). The hiking trails evaluation in the Natural Park of Serras de Aire e Candeeiros, Portugal. European Journal of Tourism, Hospitality and Recreation, 6(2), 139-156.

Carvalhinho, L., Rodrigues, L., \& Rosa, P. (2015). Avaliação de espaços naturais para a prática da escalada - Estudo de caso no parque natural das serras de aire e candeeiros (PNSAC). Journal of Sport Pedagogy \& Research, 1(3), 64-73.

Carvalhinho, L. (2015) Lazer e qualidade de vida: formação de técnicos de desporto de natureza e turismo ativo. In, R. Resende, A. Albuquerque, \& A. R. Gomes, (Eds.). Formação e saberes em desporto, educação física e lazer, 509-538. ISMAI, Maia.

Carvalhinho, L., Rosa, P., Rodrigues, L., \& Nunes, G. (2015). Formação de treinadores de desportos de natureza. estudo da auto-perceção das competências profissionais. Revista da UIIPS, 3(3), 195-210.

Carvalhinho, L., Mata, C., \& Rosa, P. (2018a). Segurança em desportos de montanha: Perceção dos fatores de risco na escalada. Em $7^{\circ}$ Congresso da Sociedade Científica de Pedagogia do Desporto. Journal of Sport Pedagogy \& Research, 4(2), 29.
Carvalhinho, L., Mata, C., \& Rosa, P. (2018b). Técnicas de avaliação do risco em atividades com cordas e cabos de aço: Estudo exploratório. Em $7^{\circ}$ Congresso da Sociedade Científica de Pedagogia do Desporto. Journal of Sport Pedagogy \& Research, 4(2), 7.

Carvalhinho, L, Mata, C., \& Rosa, P. (2019). Técnicas de avaliação do risco em escalada Estudo exploratório. In, International Congress of Adventure Tourism and Outdoor Sport (ICATOS). ESDL-IPVianaCastelo

CBI (2020). The European market potential for adventure tourism. https://www.cbi.eu/marketinformation/tourism/adventuretourism/adventure-tourism-europe

DECO. (2008). Guia dos desportos de natureza. Lisboa: Editora DECO.

Dougherty, N. (1998). Outdoor recreation safety. The State University of New Jersey: Human Kinetics.

Ferreira, G. (1998). Environmental education through hiking: A qualitative investigation. Environmental Education Research, 4(2), 177185. doi: 10.1080/1350462980040205

Gama, A., \& Carvalhinho, L. (2014). Prevenção e gestão do risco em Surf. In, L. Carvalhinho (Eds..), Desporto de natureza e turismo ativo. contextos e desenvolvimento (pp. 163-176). ESDRM-IPS, Rio Maior.

ISO 31000 (2018). International organization for standardization - 31000. Risk management Guidelines on principles and implementation of risk management. ISO/TMB WG on Risk management.

ISO 31010 (2019). International organization for standardization - 31010. Risk management - Risk assessment techniques. ISO/TMB WG on Risk management.

Jensen, B., \& Schnack, K. (1997). The action competence approach environmental education. Environmental Education Research, 3(2), 163178. doi: 10.1080/13032917.2007.9687033

Kollmuss, A., \& Agyeman, J. (2002). Mind the gap: why do people act environmentally and what are the barriers to pro-environmental behavior? Environmental Education Research, 8(3), 239260. https://doi.org/10.1080/13504620220145401

Kos, M. (2010). Outdoor play and learning in early childhood. In E. I. O. A. E. E. Learning. (Ed.), Encountering, experiencing and exploring nature in education. Eslovénia: European Institute for Outdoor Adventure Education and Experiential Learning. 
Light, R. (2006). Situated learning in an Australian surf club. Sport, Education and Society, 11(2), 155-172. doi: 10.1080/13573320600640686

Lugg, A. (2007). Developing sustainability-literate citizens through outdoor learning: Possibilities for outdoor education in higher education. Journal of Adventure Education \& Outdoor Learning, 7(2), 97-112.

Mackenzie, H., \& Brymer, E. (2018). Conceptualizing adventurous nature sport: A positive psychology perspective. Annals of Leisure Research, 23(1), 79-91.

Mata, C., \& Carvalhinho, L (2020) Seguridad y gestión del riesgo en el deporte al aire libre revisión sistemática exploratoria. Revista Euroamericana de Ciências del Deporte, 8(2), 59-64.

Prince, H. E. (2016). Outdoor experiences and sustainability. Journal of Adventure Education and Outdoor Learning, 17(2), 161-171. https://doi.org/10.1080/14729679.2016.1244645

Priest, S., \& Gass, M. (1997). Effective leadership in adventure programming. University of New Hampshire: Human Kinetics.

Rahikainen, K. (2020). Climbing as a lifestyle sport and serious leisure in China. Leisure/Loisir, 44(2), 175-197. https://doi.org/10.1080/14927713.2020.1760123

Rosa, P., \& Carvalhinho, L. (2012). A educação ambiental e o desporto na natureza: Uma reflexão crítica sobre os novos paradigmas da educação ambiental e o potencial do desporto como metodologia de ensino. Movimento, 18(3), 259280. https://doi.org/10.22456/1982-8918.27564

Rosa, P., Almeida, M., \& Carvalhinho, L. (2013). The importance of data triangulation in nature-based sport management in protected areas: The study of the Natural Park of Serras de Aire and Candeeiros. European Journal of Tourism, Hospitality and Research, 4(3), 147-180.

Rosa, P., Carvalhinho, L., \& Soares, J. (2016). Stakeholders participation in tourism and recreation planning and management in protected areas: Fundamentals on the participatory process. Tourism \& Management Studies, 12(2), 84-95. doi: 10.18089/tms.2016.12211 (ISI, IF: 0.0460).

Rosa, P., Carvalhinho, L., \& Soares, J. (2017). Developing a destination image through the perceptions of stakeholders: A case study. International Journal of Tourism Research, 1, 112. https://doi.org/10.1002/jtr.2153
Sandell, K., \& Öhman, J. (2010). Educational potentials of encounters with nature: Reflections from a Swedish outdoor perspective. Environmental Education Research, 16(1), 113132. doi: 10.1080/13504620903504065

Sato, M., Nanami, A., Bayne, C. J., Makino, M., \& Hori, M. (2020). Changes in the potential stocks of coral reef ecosystem services following coral bleaching in Sekisei Lagoon, southern Japan: Implications for the future under global warming. Sustainability Science, 15(3), 863-883. https://doi.org/10.1007/s11625-019-00778-6

Scott, D., Hall, C. M., \& Gössling, S. (2019). Global tourism vulnerability to climate change. Annals of Tourism Research, 77, 49-61. https://doi.org/10.1016/j.annals.2019.05.007

Sharma-Brymer, V., Gray, T., \& Brymer, E. (2018). Sport participation to create a deeper environmental identity with pro-environmental behaviors. In B. P. McCullough \& T. B. Kellison (Eds.), Routledge Handbook of Sport and the Environment (pp. 330-339). Routledge. https://researchdirect.westernsydney.edu.au/islan dora/object/uws\%3A44660

Silva, F., Sousa, J., Lopes, S., \& Lopes, J. (2000). Segurança em actividades de aventura. Manobras de cordas para transposição de obstáculos: MJD, CEFD.

Silva, M., Silva, F., \& Carvalhinho, L. (2013). Modelos de formação em turismo e desporto de natureza. Estudo de caso do Canyoning. In, M. Almeida, (Ed.), Turismo e desporto na natureza. (pp. 91-108) . A.D.A.Desnível \& ESHTE.

Silva, F. \& Carvalhinho, L. (2017). Turismo na natureza e de aventura. In, J. Umbelino \& F. Silva, (Eds.). Planeamento e desenvolvimento turístico. Edições LIDEL.

Stebbins, R. (2007). Serious leisure: A perspective for our time. NJ: Transaction.

Steiger, R., Scott, D., Abegg, B., Pons, M., \& Aall, C. (2019). A critical review of climate change risk for ski tourism. Current Issues in Tourism, $22(11)$,

1343-1379. https://doi.org/10.1080/13683500.2017.1410110

Zmudy, M., Curtner-Smith, M., \& Steffen, J. (2009). Student participation styles in adventure education. Sport, Education and Society, 14(4), 465-480.

https://doi.org/10.1080/13573320903217174 


\title{
O Esporte na Natureza e a Sistematização das Práticas de Aventura na Educação Física Escolar
}

\author{
Yasmim Gonçalves $^{1}$; Liana Rocha ${ }^{2}$; Luciana Venâncio ${ }^{1}$; Luiz Neto ${ }^{1}$ \\ ${ }^{1}$ Instituto de Educação Física e Esportes da Universidade Federal do Ceará \\ ${ }^{2}$ Faculdade de Educação da Universidade Federal do Ceará \\ ${ }^{3}$ Instituto de Educação Física e Esportes da Universidade Federal do Ceará
}

\begin{tabular}{|c|c|}
\hline $\begin{array}{l}\text { Palavras-chave } \\
\text { Práticas Corporais } \\
\text { de Aventura; } \\
\text { Demandas } \\
\text { Ambientais; } \\
\text { Residência } \\
\text { Pedagógica. }\end{array}$ & $\begin{array}{l}\text { RESUMO: } \\
\text { Os processos formativos de professores(as) de educação física brasileiros(as) abordam as } \\
\text { práticas corporais de aventura em alguns cursos de formação inicial e continuada. Neste artigo } \\
\text { investigamos a temática no âmbito do curso de licenciatura em educação física da Universidade } \\
\text { Federal do Ceará, no nordeste do Brasil, com estudantes que participaram do programa de } \\
\text { residência pedagógica. O objetivo é identificar como as práticas de aventura são associadas ao } \\
\text { elemento cultural esporte e à temática ambiental nos planos de aula elaborados por estudantes } \\
\text { bolsistas do programa de residência pedagógica em educação física. A metodologia é orientada } \\
\text { pela abordagem qualitativa de pesquisa, com características descritivas, e subsidiada } \\
\text { teoricamente por uma proposta de convergência temática, a partir do levantamento de } 17 \text { planos } \\
\text { de aula que abordaram a sistematização das práticas de aventura. Identificamos cinco esportes } \\
\text { de aventura para o ensino fundamental e médio, com predomínio, respectivamente, de skate, } \\
\text { parkour, slackline, surfe e paintball na temática das aulas. Como resultado, constatamos que a } \\
\text { proposta pode orientar os(as) professores(as) ao planejarem as suas aulas referentes às práticas } \\
\text { de aventura, agregando diferentes perspectivas no campo teórico e metodológico da educação } \\
\text { física. Os achados nos permitiram compreender, sobretudo, a convergência entre as práticas de } \\
\text { aventura e as demandas do ambiente. }\end{array}$ \\
\hline $\begin{array}{l}\text { Keywords } \\
\text { Adventure Bodily } \\
\text { Practices; } \\
\text { Environmental } \\
\text { Demands; } \\
\text { Pedagogical } \\
\text { Residency. }\end{array}$ & $\begin{array}{l}\text { Sport in nature and the systematization of adventure practices in school physical } \\
\text { education }\end{array}$ \\
\hline
\end{tabular}




\section{O esporte na natureza e a sistematização das práticas de aventura na educação física escolar}

O esporte é um elemento da dinâmica cultural que tem sido associado à aventura e à natureza na contemporaneidade. Esse elemento cultural tem sido pesquisado e tratado pedagogicamente no escopo de proposições teóricas, metodológicas e curriculares da educação física. No Brasil, o esporte de aventura foi incluído na temática das práticas corporais de aventura (PCA), sendo incorporado à base nacional comum curricular (BNCC) como um dos conteúdos da educação física no processo de escolarização (Inácio et al., 2016). Contudo, a sistematização das PCA alusivas ao esporte e à complexidade das demandas ambientais da natureza têm apontado para uma problemática recorrente nos processos de ensino e de aprendizagem, que é a convergência entre as dinâmicas da cultura e do ambiente (Ferreira et al., 2018; Rocha et al., 2018; Sanches-Neto et al., 2013). De certo modo, os processos formativos de professores(as) de educação física brasileiros(as) têm se preocupado com a preparação profissional para abordar as PCA. Há iniciativas de algumas disciplinas específicas sobre a temática em cursos de formação inicial e continuada de professores(as). Neste artigo investigamos a temática das PCA no âmbito de um curso de licenciatura em educação física. Durante o período de setembro de 2018 até janeiro de 2020, foram oferecidas bolsas de iniciação à docência para estudantes do curso, a partir de um programa governamental de formação de professores(as) realizado na Universidade Federal do Ceará, no nordeste do Brasil. As bolsas são recursos financeiros para que os(as) estudantes iniciem suas atividades como docentes.

Os(as) estudantes tiveram oportunidade de confrontar-se com temáticas desafiadoras, compartilhadas com professores(as) iniciantes e experientes em turmas de diferentes níveis da educação básica, sobretudo no ensino fundamental e no ensino médio. Os seus olhares, aparentemente, superaram a ideia de que a educação física, ao tratar das demandas ambientais, seria baseada na transmissão de competências teóricas. Essa perspectiva coaduna-se à argumentação de Rosa e Carvalhinho (2012), sobre a valorização do ensino vivencial e experiencial para o tratamento pedagógico criterioso do esporte na natureza e da promoção de uma consciência ambiental.

Entretanto, o processo histórico da educação física enfatizou outros propósitos ao longo do século XX e a concepção dominante tinha como perspectiva a construção de corpos mecanizados, como seres apenas biológicos. A partir dos anos 1930, o estado brasileiro se põe à frente ao desenvolver várias práticas corporais ginásticas e esportivistas, promovendo a educação física como meio de formar cidadãos com corpos saudáveis e fortes, garantindo a capacidade de enfrentar desafios do contexto social, e cidadãs saudáveis e belas, capazes de reproduzir os padrões estéticos, bem como cuidar de sua própria prole (Goellner, 2000).

Em meados da década de 1980, com a abertura política no país, a educação física passa por um processo que envolveu diversas transformações, tanto nas pesquisas quanto na prática pedagógica. Esse movimento de resistência à concepção biológica resultou em concepções teóricas e metodológicas da educação física escolar que provocaram mudanças no seu currículo, bem como discussões sobre a especificidade da escolarização ao longo dos anos 1990 (Darido \& Rangel, 2011; França \& Freire, 2009). As configurações curriculares promoveram a inserção de novos conteúdos, como as PCA, como uma das possibilidades de classificação dos elementos da cultura corporal de movimento.

Assim, as PCA são a categoria central que abordamos na nossa pesquisa. Antes da BNCC, as PCA já estavam presentes em algumas propostas curriculares regionais brasileiras e nos parâmetros curriculares nacionais $(\mathrm{PCN})$ da educação física (Rodrigues \& Darido, (2006). França e Freire (2009) explicam que os PCN sistematizam a cultura corporal de movimento em três blocos de conteúdos: (i) esportes, jogos, lutas e ginásticas; (ii) atividades rítmicas e expressivas; (iii) conhecimentos sobre o corpo. Todavia, mesmo constando nesses documentos referenciais, há dificuldades para viabilizar as PCA como conteúdo nas aulas de educação física. Santos et al. (2015) afirmam que diversos cursos de licenciatura em educação física não ofertam disciplinas relacionadas às PCA, comprometendo a qualificação profissional para trabalhar com essa temática nas escolas. Além disso, haveria pouco material sobre o ensino das PCA nas aulas. Por isso, segundo Moura et al. (2018), é importante inserir essa temática na formação inicial e continuada, além da confecção de materiais pedagógicos.

O ensino das PCA na escola apresenta alguns benefícios, como o estímulo ao interesse dos(as) estudantes em aprender conteúdos novos. Conforme Tahara e Carnicelli-Filho (2012), há predominância dos esportes coletivos (futebol, voleibol, basquetebol etc.) como conteúdo, por isso algo relativamente "novo" pode estimular os(as) estudantes a conhecer modalidades não habituais, contribuindo para diminuir o problema da evasão nas aulas de educação física. Moura et al. (2018) apontam que a contextualização das PCA pode aproximar o conhecimento presente nos conteúdos curriculares com as relações sociais, políticas e ambientais, entre outras. Logo, a construção de um pensamento crítico sobre as PCA no cotidiano dos(as) alunos(as) implica no autoconhecimento sobre os limites do corpo e nas diferentes maneiras de enfrentar a vertigem e o medo (de altura, por exemplo). Há também repercussões possíveis na compreensão de alguns preconceitos que praticantes de esportes de aventura enfrentam, mesmo no âmbito de esportes que já foram inseridos 
em grandes eventos esportivos. Antecipamos que os resultados deste artigo podem contribuir nesse sentido.

De acordo Marinho e Schwartz (2005) as PCA são atividades alternativas e criativas de expressão humana, manifestadas, principalmente, nos momentos de lazer, com características inovadoras e diferenciadas dos esportes tradicionais, pois as condições de prática, os objetivos, a própria motivação e os meios utilizados para o seu desenvolvimento são outros. São percebidas como práticas criadas na ruptura com as práticas convencionais. Os exemplos se estendem desde simples caminhadas aos mais sofisticados e excitantes esportes, apresentando características que as diferem dos esportes tradicionais. Podem ser classificadas como atividades corporais terrestres, aquáticas, aéreas, urbanas e de natureza, classificadas de acordo com o local para a realização da prática. Além disso, há também a presença de inovadores equipamentos tecnológicos, permitindo uma fluidez entre o(a) praticante e o ambiente destinado às práticas.

Utilizamos a nomenclatura das PCA porque é mais abrangente e por isso mais adequada ao propósito desta pesquisa, permitindo a inclusão das diversas significações que esse objeto de estudo pode assumir diante dos mais variados contextos. Reconhecemos a relação dialógica das PCA com a dinâmica da cultura e o princípio da especificidade caracterizada pela condição da aventura, compreendendo a existência de uma ligação entre esse campo e a natureza, mas refletimos que essas práticas também ocorrem nos meios urbanos (Marinho \& Schwartz, 2005). Assim, há um alargamento conceitual nas PCA - que abrange noções como "esporte na natureza", "esporte de aventura" e "prática de aventura" - que se coaduna a um propósito da educação física na escolarização quanto à problematização da diversidade dos elementos da cultura. Diante dessa compreensão a respeito das PCA, o nosso artigo tem o objetivo de identificar como as práticas de aventura são associadas ao elemento cultural esporte e à temática ambiental nos planos de aula elaborados por estudantes bolsistas do programa de residência pedagógica em educação física.

\section{As PCA e a educação física na escolarização}

Ao longo dos processos históricos de consolidação das comunidades humanas, os seres humanos têm se envolvido com atividades assemelhadas às PCA como pesca, escalada em árvores, travessia de rios etc. - com o propósito de interagir com o ambiente e sobreviver. De modo dinâmico e complexo, as PCA emergem com novas caracterizações e atribuições, como atividades de lazer que proporcionam o retorno do ser humano à natureza - como se cada ser humano tivesse se desprendido do mundo "natural" - em diferentes espaços, na terra, na água ou no ar (Moura et al., 2018)
Além disso, na contemporaneidade, houve a transposição de algumas práticas corporais para o meio urbano, como o skate, slackline, parkour, entre outras. O parkour, por exemplo, caracteriza-se pelo deslocamento do(a) praticante sobre diferentes superfícies, ao passo que na natureza seria o deslocamento sobre pedras, árvores, travessias de rios, entre outros obstáculos. Todavia, no ambiente urbano, adapta-se a locomoção a bancos de praças, muros, prédios, entre outros (Alves \& Corsino, 2013). Quanto à esportivização das PCA, de acordo com Moura et al. (2018), a prática frequente como forma de lazer - pelo prazer de aventurar-se - alcança aceitação e repercussão. Então, à medida que muitos(as) praticantes buscavam aperfeiçoar suas técnicas, foram surgindo competições e organizações (federações, associações etc.) que institucionalizaram as PCA. Não obstante, durante o processo de esportivização, algumas práticas foram marginalizadas e são alvos recorrentes de preconceito por parte da população. Com isso, faz-se necessário dialogar sobre os preconceitos e as discriminações que envolvem as PCA, como no caso dos(as) skatistas e dos(as) surfistas que eram rotulados(as) como rebeldes e usuários(as) de drogas (Moura et al., 2018).

Além disso, há poucos esportes de aventura presentes nos jogos olímpicos de verão, como o ciclismo $B M X$ e mountain bike. Todavia, em 2016, o comitê olímpico internacional (COI) incluiu cinco novas modalidades esportivas, sendo três delas esportes de aventura. A expectativa era que a estreia do skate, do surfe e da escalada esportiva ocorresse na edição de 2020 das olimpíadas, postergadas - com certa relutância do COI - devido à pandemia de covid-19. Com a esportivização das PCA alguns paradigmas foram quebrados, conferindo maior visibilidade aos(às) praticantes no contexto social. O interesse educacional em abordá-las no contexto escolar, com o foco nas aulas de educação física, decorre também da possibilidade de ampliação dos saberes dos(as) alunos(as) com relação aos elementos culturais.

Porém, como as aulas de educação física até o século passado possuíam explicitamente um caráter esportivista, mesmo com as mudanças nas metodologias de ensino ainda há uma herança da esportivização. Tendo isso em vista, diversos(as) professores(as) - preocupados(as) em qualificar suas práticas por meio da pesquisa - tentam ampliar suas práticas docentes para enfrentar esse problema encontrado em suas aulas. Logo, algumas estratégias que enfatizam as vivências de novos conteúdos são utilizadas. Conforme Tahara e Darido (2016), há metodologias de ensino para algumas PCA nas aulas de educação física, como o ciclismo, corrida de orientação, atividades sobre rodas (skate, patinetes e patins), modalidades aquáticas (acqua rider, canoagem, surfe, mergulho), parkour, montanhismo, trekking, slackline, arvorismo, rapel e escalada. 
Essa temática é usualmente atrelada a temas transversais que tornam o ensino dessas PCA não apenas um aprendizado sobre o esporte, mas que visa, por meio dele, à transformação da individualidade de cada sujeito. Tahara e Darido (2016) trazem um levantamento bibliográfico das PCA, tanto nas aulas de educação física como em atividades extracurriculares, no qual é possível observar os temas transversais atrelados às práticas. Quando falamos da sistematização desse conteúdo nas aulas de educação física há associação com objetivos que perpassam a elaboração de conhecimentos sobre autoconfiança, superação de limites, respeito, cooperação e autodisciplina, expressão corporal, valorização da ética e conscientização do impacto das ações do ser humano no meio ambiente. Além disso, Tahara e Darido (2016) acrescentam que há necessidade de explorar as três dimensões (conceitual, procedimental e atitudinal) desses conteúdos a partir dos PCN.

Atualmente, há desafios às PCA que podem ser entendidos como justificativas da negação desse conteúdo nas aulas, como a falta de disciplinas que abordem a temática no currículo dos cursos de educação física das universidades. Tendo isso em vista, diversos(as) estudantes da graduação recorrem a cursos, workshops e grupos informais para aprenderem sobre esses esportes com a intenção de sistematizá-los em suas aulas. Há também o envolvimento com estudantes de outros cursos de licenciatura por meio de iniciativas interdisciplinares que valorizam a complexidade das PCA (Porretti et al., 2020).

\section{Blocos de conteúdos temáticos e as demandas ambientais}

A sistematização dos conteúdos e temas de ensino da educação física é subsidiada por entendimentos científicos que buscam superar a perspectiva da educação física baseada estritamente em aspectos biológicos (Sanches-Neto \& Betti, 2008). A partir da década de 1980, as proposições de caráter pedagógico diferenciavam-se das abordagens ancoradas em referências biologistas. Além dos PCN (Brasil, 1998), que buscaram tratar de problemas sociais urgentes no formato de temas transversais, há perspectivas da educação física que se preocuparam com a inclusão e a participação plena dos(as) alunos(as) em elementos da cultura corporal de movimento.

Entre esse agrupamento de abordagens, conteúdos e temáticas transversais, ressaltamos uma proposta de sistematização dos conteúdos da educação física em quatro blocos temáticos a partir da convergência entre as dinâmicas da (1) cultura, do (2) corpo, do (3) movimento e do (4) ambiente.

Para Sanches-Neto e Betti (2008), cada bloco é organizado em seis temáticas recorrentes.

(1) Os elementos culturais - dinâmica da cultura compreendem o jogo e a brincadeira, o esporte, a dança, a ginástica e o circo, a luta e a capoeira, as vivências e as atividades da vida diária (AVD). O propósito da aprendizagem dessa temática é "compreender e diferenciar os elementos culturais, refletindo criticamente e vivenciando suas diversas manifestações" (Sanches-Neto, 2017, p. 27).

(2) Os aspectos (inter)pessoais - dinâmica do corpo compreendem noções de anatomia e biomecânica, antropologia e psicologia, bioquímica e nutrição, embriologia e fisiologia, comportamento motor, saúde e patologia. De acordo com Sanches-Neto e Betti (2008), a expectativa de aprendizagem é que essas temáticas possibilitem melhoria na compreensão do próprio organismo e das intersubjetividades dos seres humanos em movimento, em termos quantitativos e qualitativos (repertório de movimentos).

(3) No terceiro bloco - com ênfase na dinâmica do movimento - há destaque para a tipologia de movimentos (fundamentais, combinados e especializados), que compreendem habilidades de estabilização, manipulação, locomoção, combinação e especialização de movimentos, ritmo, capacidades e noções de treinamento. Nesse bloco, conforme Sanches-Neto (2017), o propósito da aprendizagem é a compreensão e a vivência de possibilidades complexas de realização de movimentos para enfrentar necessidades específicas.

(4) De modo convergente aos demais blocos, as demandas ambientais - dinâmica do ambiente trazem a problematização de que o ambiente é complexo e não se restringe à discussão superficial sobre "meio ambiente" ou "sustentabilidade ambiental", porque o ambiente capitalista contemporâneo não é sustentável (Sanches-Neto et al., 2013). A dinâmica do ambiente abrange demandas administrativas e econômicas, estéticas e filosóficas, físicas e naturais, históricas e geográficas, virtuais, sociológicas e políticas. Para Sanches-Neto e Betti (2008) e Sanches-Neto (2017), o propósito da aprendizagem nesse bloco corresponde à problematização das diferentes demandas ambientais, na perspectiva de transformação e de adaptação dos recursos disponíveis, intervindo no ambiente de forma a analisar, criticar, modificar e solucionar. As demandas do ambiente identificadas no contexto das PCA possibilitam compreender as diversas dimensões existentes nesse universo específico, permitindo dialogar com suas várias significações.

Contudo, Sanches-Neto e Betti (2008) ressaltam que, dependendo do processo reflexivo compartilhado entre professores(as) e alunos(as), as temáticas dos blocos de conteúdos podem ser alteradas. Logo, a convergência dos blocos temáticos não se constitui como uma maneira única de planejamento das aulas, visto que podem ocorrer mudanças a partir do contexto social que professores(as) e alunos(as) estão inseridos. Ademais, os blocos não pressupõem uma hierarquia na sistematização, ou seja, eles podem ser utilizados de forma horizontal, pois não existe um bloco mais ou menos importante que outro. Para 
Sanches-Neto e Betti (2008, p. 15), "a elaboração dos conteúdos em todas as suas dimensões é crucial para a manutenção da coerência integrativa da intervenção". Sendo assim, para caracterizar a convergência torna-se necessário assumir uma das temáticas de cada bloco, pois, de acordo com Sanches-Neto (2017), a singularidade da educação física escolar não se apresenta em qualquer conteúdo de forma isolada.

\section{Metodologia}

Esta é uma pesquisa qualitativa com características descritivas, subsidiada teoricamente pela proposta de sistematização de conteúdos temáticos (SanchesNeto \& Betti, 2008; Sanches-Neto et al., 2013; Sanches-Neto, 2017). Metodologicamente, o ponto de partida da investigação é a análise dos planos de aula compartilhados por 48 estudantes que participaram do Programa Institucional de Bolsas de Residência Pedagógica como residentes bolsistas, desde setembro de 2018 até janeiro de 2020. A análise foi subsidiada por pressupostos da argumentação prática, a partir dos planos de aula, de acordo com Borges e Sanches-Neto (2014). A proposta de sistematização foi vislumbrada como um dos caminhos possíveis para o ensino das PCA na educação física escolar. $\mathrm{O}$ foco específico da análise envolveu os planos que trataram o tema das PCA e a identificação dos pressupostos da sistematização dos blocos de conteúdos temáticos (Sanches-Neto et al., 2013). Os pressupostos são de convergência e de integração entre as quatro dinâmicas, portanto todos os planos de aula deveriam integrar no mínimo um dos seis temas de cada bloco (como consta na Figura 1). Como critério de pertinência, foram considerados somente os planos de aula sobre PCA construídos e aplicados no período de realização do programa no curso de educação física.

Figura 1 - Blocos de conteúdos temáticos

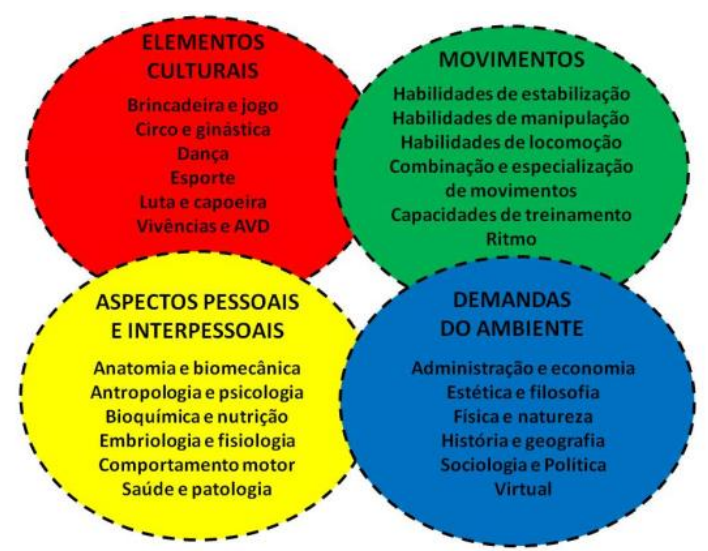

Fonte: Sanches Neto (2017).

Primeiramente, foram resgatados todos os planos de aula sobre PCA aplicados nas seis escolas públicas cadastradas no programa de residência pedagógica.
Em seguida, esses planos foram decodificados e analisamos os temas, os objetivos, os conteúdos, as estratégias, os critérios e os instrumentos de avaliação e as referências utilizadas em cada plano de aula. Então, analisamos a relação desses códigos com os blocos de conteúdos temáticos e esboçamos uma sistematização dos conteúdos a partir da identificação das temáticas que fundamentaram os planejamentos das aulas sobre as PCA. O foco da análise foi, portanto, nos conteúdos. Agrupamos os achados de acordo com a ênfase variável em cada bloco de conteúdo, que correspondem ao formato que escolhemos para a discussão dos resultados.

O programa de residência pedagógica foi financiado pela CAPES, agência de fomento responsável pela Coordenadoria de Aperfeiçoamento do Pessoal do Ensino Superior, vinculada ao Ministério da Educação. Teve como objetivo aperfeiçoar a formação dos(as) discentes de cursos de licenciatura, por meio do desenvolvimento de projetos que conduzem o(a) licenciando a exercitar de forma ativa a relação entre teoria e prática profissional docente. A partir de um edital, os cursos contemplados com esse programa tinham a composição de um núcleo, composto por um(a) coordenador(a) (docente do curso de graduação apto(a) para essa função), três preceptores(as) (professores(as) da rede pública que trabalham em escolas inscritas previamente no edital) e vinte e quatro residentes bolsistas (estudantes do curso da graduação em licenciatura) sendo distribuídos oito residentes para cada escola. Entretanto, o curso de educação física foi contemplado duplamente no edital. Foram formados dois núcleos, contando com o dobro de participantes da educação física - dois(as) coordenadores(as), seis preceptores(as) e 48 residentes - em relação a outras áreas. Entre as escolas públicas contempladas no programa - todas localizadas em Fortaleza, capital do estado do Ceará - há uma escola de tempo integral (a quase totalidade das escolas brasileiras funciona em turnos parciais), uma escola associada à plataforma google (que recebe subsídios através de equipamentos e serviços dessa plataforma, como uma sala com aparelhos eletrônicos, projetor, impressora 3D e outros acessórios) e uma escola militar (subordinada às diretrizes da hierarquia militar, embora tenha um projeto político e pedagógico que menciona a perspectiva educacional de Paulo Freire). Durante o período do programa, os(as) residentes estavam à frente das turmas juntamente com seus(as) preceptores(as), possuíam responsabilidades de planejamento das aulas, de avaliação e de realização de atividades extracurriculares. Além do contexto docente, os(as) residentes eram organizados pelos(as) coordenadores(as) - para reuniões e discussões sobre metodologias de ensino, avaliação, sistematizações e feedback das aulas. Foi no contexto dessas reuniões que houve a discussão sobre uma alternativa para a sistematização dos conteúdos nas aulas de educação física, que fundamenta o nosso 
estudo. Em síntese, realizamos o levantamento dos planos de aula com autorização prévia dos(as) residentes que os(as) elaboraram e dos(as) preceptores(as) que supervisionaram as intervenções e ações de planejamento.

Com relação às questões éticas, a participação nesta pesquisa ocorreu de forma voluntária com o consentimento de cada participante. A pesquisa faz parte de um projeto mais amplo, aprovado previamente pelo Núcleo de Pesquisa institucional sob o código NP020, e não acarretou riscos aos(às) participantes. Além desse cuidado, preservamos o anonimato e a confidencialidade dos dados. Os planos foram elaborados a partir de um modelo (template) no formato do editor de texto word (contudo, o modelo não era obrigatório) e abrangeram 17 aulas, sendo que a análise de cada plano foi realizada colaborativamente pelos(as) autores(as) deste estudo.

\section{Resultados e Discussão}

Identificamos cinco PCA nos planejamentos e agrupamos os planos de acordo com cada esporte de aventura. Os níveis de ensino contemplados com essas aulas variaram em turmas de séries finais do ensino fundamental (6o ao 9o ano) e do ensino médio. Foram analisados 17 planos de aula sobre práticas de aventura, tendo os seguintes esportes e quantidades: paintball (1); surfe (2); slackline (2); parkour (5); skate (7). A tabela abaixo apresenta as PCA presentes em cada plano de aula.

Tabela 1 - Planos de aulas temáticas

\begin{tabular}{|c|c|c|c|}
\hline $\begin{array}{l}\text { Elementos } \\
\text { culturais }\end{array}$ & Movimentos & Aspectos (inter)pessoais & Demandas ambientais \\
\hline paintball & $\begin{array}{l}\text { habilidade de locomoção; } \\
\text { habilidade de manipulação }\end{array}$ & comportamento motor & administração e economia \\
\hline surfe & $\begin{array}{l}\text { capacidades e treinamento; } \\
\text { habilidades de estabilização }\end{array}$ & anatomia e biomecânica & $\begin{array}{l}\text { física e natureza; história e } \\
\text { geografia }\end{array}$ \\
\hline surfe & $\begin{array}{l}\text { não houve associação } \\
\text { identificável }\end{array}$ & comportamento motor & $\begin{array}{l}\text { história e geografia; sociologia e } \\
\text { política; física e natureza; } \\
\text { estética e filosofia }\end{array}$ \\
\hline slackline & $\begin{array}{l}\text { habilidades de estabilização; } \\
\text { capacidades e treinamento }\end{array}$ & $\begin{array}{l}\text { anatomia e biomecânica; } \\
\text { antropologia e psicologia }\end{array}$ & $\begin{array}{l}\text { história e geografia; física e } \\
\text { natureza }\end{array}$ \\
\hline slackline & $\begin{array}{l}\text { combinação e } \\
\text { especialização }\end{array}$ & anatomia e biomecânica & física e natureza \\
\hline parkour & habilidades de estabilização & saúde e patologia & história e geografia \\
\hline parkour & $\begin{array}{l}\text { habilidades de estabilização; } \\
\text { combinação e } \\
\text { especialização }\end{array}$ & anatomia e biomecânica & física e natureza \\
\hline parkour & $\begin{array}{l}\text { habilidades de estabilização; } \\
\text { combinação e } \\
\text { especialização }\end{array}$ & $\begin{array}{l}\text { antropologia e psicologia; } \\
\text { comportamento motor }\end{array}$ & $\begin{array}{l}\text { história e geografia; física e } \\
\text { natureza }\end{array}$ \\
\hline parkour & $\begin{array}{l}\text { habilidades de estabilização; } \\
\text { combinação e } \\
\text { especialização }\end{array}$ & anatomia e biomecânica & $\begin{array}{l}\text { história e geografia; física e } \\
\text { natureza }\end{array}$ \\
\hline parkour & $\begin{array}{l}\text { habilidades de estabilização; } \\
\text { combinação e } \\
\text { especialização }\end{array}$ & comportamento motor & $\begin{array}{l}\text { história e geografia; física e } \\
\text { natureza }\end{array}$ \\
\hline skate & habilidades de estabilização & $\begin{array}{l}\text { anatomia biomecânica; } \\
\text { comportamento motor }\end{array}$ & história e geografia \\
\hline skate & habilidades de estabilização & comportamento motor & $\begin{array}{l}\text { não houve associação } \\
\text { identificável }\end{array}$ \\
\hline
\end{tabular}




\begin{tabular}{llll} 
skate & $\begin{array}{l}\text { não houve associação } \\
\text { identificável }\end{array}$ & comportamento motor & $\begin{array}{l}\text { história e geografia; sociologia e } \\
\text { política }\end{array}$ \\
skate & habilidades de estabilização & anatomia e biomecânica & física e natureza \\
skate & habilidades de estabilização & $\begin{array}{l}\text { anatomia e biomecânica; } \\
\text { comportamento motor }\end{array}$ & $\begin{array}{l}\text { não houve associação } \\
\text { identificável }\end{array}$ \\
skate & $\begin{array}{l}\text { habilidades de } \\
\text { especialização; combinação }\end{array}$ & anatomia e biomecânica & $\begin{array}{l}\text { não houve associação } \\
\text { identificável }\end{array}$ \\
e especialização & $\begin{array}{l}\text { combinação e } \\
\text { skate }\end{array}$ & $\begin{array}{l}\text { anatomia e biomecânica; } \\
\text { antropologia e sociologia }\end{array}$ & física e natureza \\
\hline
\end{tabular}

Nota: registros do programa de residência pedagógica

As PCA e os elementos culturais nos planejamentos

A análise dos planos que trataram das PCA revelou o predomínio da temática do esporte no bloco associado à dinâmica da cultura. Foram identificados cinco esportes, sendo o skate o mais frequente. Contudo, mesmo sabendo que as PCA estão intrinsecamente vinculadas a algum modo de sobrevivência do ser humano, as práticas não poderiam ser consideradas como esporte, por não terem os mesmos objetivos atribuídos às muitas práticas atuais (Moura et al., 2018). Logo, as práticas foram se tornando mais populares na sociedade e tomaram seus espaços no contexto esportivo, buscando respaldar-se em competições e federações. Antes, essas práticas que eram consideradas atividades de lazer, tornaram-se esportes presentes em grandes campeonatos como jogos olímpicos e $X$ games.

Entendemos que os esportes de aventura tornaram-se populares mundialmente e diversas comunidades promovem algumas dessas práticas para manutenção social (Pimentel, 2013). Houve construção de pistas de skate nas praças públicas de Fortaleza, além de projetos sociais relacionados ao surfe em algumas praias do estado do Ceará. Essas PCA são ressignificadas pela ação e representação humana, por meio de relações estabelecidas, "portanto, o termo esporte na natureza, ao mesmo tempo em que pode ser remetido a predecessores arcaicos, diz respeito a algo conhecido e compreendido na atualidade" (Pimentel, 2013, p. 690). Com isso, essas práticas entram na forma de conteúdo da educação física escolar, como estratégia de ensino e aprendizagem dos(as) estudantes, na sua formação. Ainda, na análise dos planejamentos tivemos o slackline, que perpassou a temática de esporte, a ginástica e o circo. É notório que a habilidade fundamental do slackline é o equilíbrio; no entanto, essa habilidade atravessa diversas outras práticas. Trazendo à tona as práticas circenses observamos os(as) equilibristas na travessia da corda bamba, que se assemelha à prática citada. Sanches-Neto e Betti
(2008) afirmam que a proposta dos blocos de conteúdos temáticos não constitui uma possibilidade única e propõem que, por um lado, os conteúdos devem ser sistematizados, mas, por outro lado, a sistematização também deve ser flexível adaptandose a cada contexto, admitindo que pode haver predominância de um ou outro tema nas aulas.

\section{As PCA e os movimentos nos planejamentos}

Saches-Neto e Betti (2008) traçam como objetivo específico desse bloco a compreensão e a vivência de alternativas de combinações de movimentos para responder a necessidades específicas. Diante dos resultados dessa pesquisa, observamos que os planejamentos atravessaram por quase todas as temáticas desse bloco, porém as habilidades de estabilização e de locomoção, bem como a combinação e a especialização de movimentos foram as temáticas que abrangeram majoritariamente as PCA.

Embora todas as ações de movimento envolvam o equilíbrio, apenas os movimentos que mantêm a orientação corporal estável são denominados habilidades de estabilização. Equilibrar-se sobre uma barra estreita, rolamento do corpo e movimentos axiais de flexão e alongamentos são algumas ações que se enquadram nessa categoria (Gallahue, 2002). Essas habilidades foram bastante salientadas nos planejamentos das aulas de parkour, slackline, surfe e skate. Foi possível observar algumas estratégias, como os rolamentos do corpo, no parkour. E os movimentos axiais, como flexionar, foram identificados no slackline, que se faz necessário a flexão dos joelhos para melhor estabilização na corda e no skate e surfe para melhor equilíbrio e direcionamento dos movimentos.

Por sua vez, o movimento primordial do slackline é o equilíbrio, que teve diversas variações aplicadas nas aulas, desde apenas tentar ficar sentado e/ou em pé mantendo o equilíbrio no slackline, ao auxílio de colegas para melhor segurança e equilíbrio na travessia. Além de estratégias anteriores à vivência das PCA, como o equilíbrio em diferentes superfícies 
(atravessar a trave de vôlei, disposto em uma superfície horizontal), presente em um das aulas de surfe. No skate, descobrir o pé de apoio (aquele que ficará apoiado na parte da frente no skate) tornou-se uma das estratégias primárias quando se trabalhou com essa PCA na escola (atividades de empurrar cada colega e o pé que primeiro for à frente será o pé de apoio, entre outras possibilidades).

Habilidades de locomoção, como o nome sugere, são formas de nos locomovermos em superfícies verticais e/ou horizontais. Gallahue (2002) explica que os movimentos que têm como objetivo conduzir o corpo de um ponto a outro, como corrida, salto em altura e corrida com obstáculos, são exemplos de tarefas locomotoras. Com a análise dos planejamentos, na vivência do paintball, a corrida se torna uma das habilidades mais ativas, pois essa atividade tinha como objetivo a captura do brasão de sua equipe, no campo adversário. E a habilidade de saltar torna-se evidente no parkour, pois um dos movimentos específicos são os saltos de uma superfície a outra ou sobre obstáculos (no caso da escola, cadeiras e mesas).

Identificamos o paintball como uma PCA, tendo como base o conceito partilhado por Braga, Furlanetto e Nazari (2007) ao mencionarem a caminhada em trilhas, a escalada, o mountain bike, o surfe e o paintball como exemplos de esporte de aventura. O paintball pode ser classificado como uma PCA pela mobilização emocional intensa associada à adrenalina dos(as) envolvidos(as), assim como por sua relação com a temática ambiental, sendo comumente realizado em espaços amplos ao ar livre, como parques e florestas.

Já a temática de combinação e especialização implica em uma diferenciação. Entende-se por combinação o agrupamento de diversos movimentos e habilidades, visto que na construção de um planejamento de aula dificilmente o(a) professor(a) enfatiza apenas uma habilidade, certamente alguma pode entrar em evidência, mas haverá habilidades secundárias sendo desenvolvidas. A especialização, na escola, podemos compreender como o desenvolvimento e/ou aprimoramento motor dos(as) estudantes, seguindo o princípio da individualidade. A temática pode ser entendia com "os movimentos especializados, ou os movimentos complexos como às vezes são denominados, constituem movimentos fundamentais que foram refinados ou combinados com outros movimentos em formas mais complexas" (Gallahue, 2002, p. 110).

Nas práticas do parkour observamos a combinação de habilidades como saltar (locomoção), flexionar e rolar (estabilização). A especialização se manifesta na progressão de cinco planejamentos de aula sobre skate. As primeiras aulas estruturadas sobre a historicidade e conhecer as habilidades primárias, mais à frente o equilíbrio e a locomoção no skate, por fim alguns desafios como obstáculos a serem desviados e manobras simples. No slackline, foi possível observar a especialização, quando foram propostos desafios como tentar manter o equilíbrio por mais tempo e o aumento da distância que cada aluno(a) poderia atravessar na fita.

\section{As PCA e os aspectos (inter)pessoais nos planejamentos}

Durante as aulas de educação física, os(as) universitários(as) não são orientados(as) pelos(as) professores(as) apenas a focar nos movimentos de forma isolada, mas a relacioná-los com implicações psicológicas (empolgação, medo, angústia, euforia etc.). França e Freire (2009) salientam que é importante trabalhar com essas temáticas não focando apenas nas sensações de prazeres durante a aula ou motivar os(as) alunos(as) para as próximas aulas, mas discutir diferentes sentimentos e sensações que perpassam o ambiente, desde a sensação de vitória à derrota.

No processo histórico da educação física no Brasil, tivemos influência da vertente higienista, baseada na realização de exercícios físicos com o objetivo de obter um corpo fisicamente saudável. Adiante, a cinesiologia, que promove o estudo do movimento humano, mas que fomenta estudos de forma fragmentada e parcial, atendendo características mecânicas, como deslocamento do corpo e seus segmentos, considerando os tipos de sobrecarga e fatores ambientais (Sanches-Neto \& Betti, 2008). Com os avanços nos estudos, imergimos na ciência da motricidade humana, que compreende as interrelações culturais e biológicas do movimento humano (Sanches-Neto \& Betti, 2008).

Assim, fundamentam-se as temáticas de anatomia e de biomecânica quando trata-se dos movimentos anatômicos nas práticas de slackline, parkour, skate e surfe. Partimos do pressuposto de que os(as) estudantes devem compreender como são realizados os movimentos anatômicos dos esportes trabalhados nas aulas. Como no slackline, em uma estratégia, o(a) professor(a) orientava os(as) estudantes sobre o posicionamento do corpo na fita, a posição dos pés um em frente ao outro, joelhos semiflexionados, sendo que o olhar deve estar em um ponto fixo e o abdômen contraído. Nas aulas de surfe, os(as) residentes utilizaram o skate para demonstração dos movimentos da remada no surfe.

Entretanto, esses movimentos não devem ser trabalhados de forma isolada, apenas no seu sentido biológico, por exemplo, mas por meio da integração aos aspectos culturais, como as vivências anteriores com o esporte, que podem ser fatores negativos ou positivos para realizar essa PCA. Sobre a temática das noções de antropologia e psicologia, segundo Laplantine (2003), a antropologia divide-se conforme sua ênfase em vários aspectos, como social, cultural, psicológica e biológica. Entende-se que a antropologia biológica lida com aspectos como transformações de caracteres biológicos do ser humano no espaço e no tempo (Laplantine, 2003). 
Encontramos correspondência dessa interpretação nas práticas de surfe e parkour, quando os(as) residentes apresentam nos planejamentos a discussão sobre a possível origem dessas práticas e relacionam os movimentos do parkour à sobrevivência do ser humano na pré-história. Para dialogar sobre essa temática, observamos estratégias distintas, como o uso apenas da oralidade, promovendo discussões, e a utilização de história em quadrinhos.

Ainda mais, atrela-se a prática ao meio em que o(a) estudante vive, esta que foi uma das estratégias de alguns(as) residentes que agregavam as vivências dos(as) estudantes do parkour ao meio em que vivem. Observamos estratégias como discussões que associavam a historicidade e as características particulares dessa prática à vida cotidiana dos(as) estudantes. Embora os estudos sobre as PCA no contexto da educação física escolar ressaltem os aspectos psicológicos, França e Freire (2009) salientam que é necessário discutir os sentimentos que perpassam durante a aula, mesmo que sejam de desapontamento. Segundo Sanches-Neto e Betti (2008), o(a) professor(a) poderia mediar o entendimento sobre as concepções originárias da psicologia na sua intervenção pedagógica.

As estratégias utilizadas nos planejamentos analisados não se pautam apenas na vivência da prática, pois isso, possivelmente, levantaria questionamentos como "O que mudará na vida de um(a) estudante aprender a andar de skate?" Por isso, Sanches-Neto e Betti (2008) defendem a característica de flexibilidade, de modo que os questionamentos sobre o porquê de estar vivenciando tais práticas fundamenta-se nas diversas dimensões que abrangem o(a) estudante e o campo da educação física. Com a análise dos planejamentos, tornou-se evidente que aspectos psicológicos são estimulados durante as vivências das PCA. Algumas das estratégias articuladas pelos(as) professores(as) nas aulas de slackline, por exemplo, propõem que, ao final da aula, os(as) estudantes dialoguem sobre suas sensações. Além disso, os(as) próprios(as) estudantes construíram circuitos de parkour; nessa construção, observamos aspectos de cooperação e respeito aos(às) colegas. Há ainda estratégias nas aulas de skate em que os(as) colegas que já possuíam afinidade na modalidade auxiliariam aqueles(as) que possuem dificuldade no equilíbrio e/ou se locomover no skate, com respeito e cooperação.

\section{As PCA e as demandas ambientais nos planejamentos}

Encontramos alguns(as) autores(as) que dialogam sobre as demandas ambientais - como Ferreira et al. (2018) e Rocha et al. (2018) - e explicam que a temática provém de uma perspectiva ampliada da relação do que se entende sobre o ambiente, não focando apenas na perspectiva de "sustentabilidade ecológica", mas considerar tudo aquilo que existe no mundo, de modo a nos envolvermos e sofrermos as influências a partir do contexto social, cultural e político em que estamos inseridos(as). Tendo em vista a análise dos planejamentos, foi possível observar que as PCA perpassam por quase todas as temáticas. Entretanto algumas tornaram-se mais evidentes na maioria nos planejamentos, como no caso do surfe e do parkour.

De acordo com Rocha (2017), o surfe tem se configurado também em um campo de intervenção pedagógica construído mediante uma diversidade de ações, que variam desde a implantação de escolinhas de surfe voltadas ao treinamento esportivo à existência de projetos comunitários que utilizam o surfe como prática educativa. Há organizações não governamentais (ONGs), escolinhas e projetos que afirmam usar o surfe como agente socialmente transformador, proporcionando noções de cidadania e conscientização social.

A temática das demandas ambientais históricas e geográficas esteve presente nos planejamentos de surfe, skate e parkour. Nas aulas de surfe, os(as) residentes atrelaram a modalidade de skate ao surfe, questionando qual possivelmente teria surgido primeiro, além de semelhanças entre essas modalidades. Além disso, nas aulas de parkour, foram mostrados registros da possível origem dessa prática, por meio de imagens dos movimentos.

As demandas sociológicas e políticas enquadram-se nas aulas de surfe e skate, respectivamente, pois nesses planejamentos específicos os(as) residentes frisaram temáticas sobre preconceitos que permeiam esses esportes, como homofobia e relações enviesadas de gênero. Além de solicitar relatos dos(as) estudantes sobre vivências anteriores na prática da modalidade, outra das estratégias observadas foi a problematização por parte dos(as) residentes com o questionamento se a prática do skate é um conteúdo pertencente à educação física. Essa problematização permeia a temática de política, considerando as relações de poder subjacentes às PCA e sua institucionalização.

A temática das demandas ambientais físicas e da natureza, para Sanches-Neto et al. (2013), consiste nas vivências das aulas de educação física que não se restringem apenas à quadra esportiva, mas que consideram a relevância da fauna e da flora, bem como variações climáticas, de terreno etc. na realização das PCA. Entendemos que essa perspectiva remete à relação das práticas de aventura com as demandas da natureza e o fomento, por parte dos(as) residentes, à preservação e à mobilização dos(as) alunos(as) para transformações que tenham o sentido da justiça social.

\section{Reflexões finais}

Tendo em vista a reflexão sobre a relação dos elementos da natureza com as práticas de aventura, que fundamentam a base teórica deste estudo, optamos por não relacionar os planejamentos das 
PCA apenas com a temática das demandas físicas do ambiente e a natureza, considerando que diversos estudos já estimulam essa relação. $\mathrm{O}$ entendimento que explicitamos neste artigo é de que a relação das PCA com o ambiente é mais ampla e complexa. Por isso, preferimos relacionar outras demandas ambientais (econômicas, geográficas, históricas, políticas etc.) às práticas de aventura, que pouco observamos em outros estudos. Consideramos que nossa pesquisa contribui para suprir essa lacuna.

Identificamos que o tratamento pedagógico dessas práticas no contexto escolar difere das metodologias usadas para enfatizar o rendimento e/ou lazer, indicando que foram agregadas metodologias pedagógicas às PCA. Entretanto, há incertezas sobre como essas práticas podem ser apresentadas de modo mais eficaz e problematizadas de modo mais crítico no contexto escolar, mais especificamente nas aulas de educação física. Nesse sentido, vislumbramos uma possibilidade de sistematizar as PCA por meio dos blocos de conteúdos temáticos.

A partir dessa sistematização e por meio da análise de planejamentos de aulas sobre as práticas de aventura, elencamos diferentes temáticas que podem perpassar esse conteúdo como os elementos culturais, os aspectos (inter)pessoais, a dinâmica dos movimentos e das demandas ambientais. De forma ampla, conseguimos identificar que os(as) residentes aplicaram suas aulas contemplando a complexidade das diversas abordagens da educação física escolar. Consideremos que esse indício corrobora a flexibilidade da proposta, confirmando que não há uma hierarquização ou pré-requisitos entre os conteúdos. Assim, os planejamentos de aulas podem abranger mais temáticas de um bloco de conteúdos do que de outros; todavia, é necessário escolher pelo menos uma temática de cada bloco.

Concluímos que essa proposta pode orientar os(as) professores(as) ao planejarem as suas aulas, agregando diversas abordagens no campo teórico e metodológico da educação física. Ressaltamos que nesta pesquisa nos limitamos a observar os conteúdos e as temáticas que perpassam as PCA a partir dos planos de aula, mas avançamos na compreensão de que há convergência entre as PCA e as demandas do ambiente. Notamos que há estudos que enfatizam atributos de apenas um dos blocos de conteúdos temáticos ao problematizar as práticas de aventura na perspectiva de professores(as) - iniciantes e experientes - e de estudantes(as). Entretanto, ao invés de investigar aspectos isolados, sugerimos que é necessário estudar mais as convergências apontadas por essa proposta de sistematização.

\section{Referências}

Alves, C. S., \& Corsino, L. N. (2013). O parkour como possibilidade para a educação física escolar. Motrivivência, 41, 247-257.
Braga, H. F., Furlanetto, D., \& Nazari, J. (2007). Paintball, estratégia e inteligência: Uma alternativa para o esporte e o lazer. e-balonmano - Revista Digital Desportiva, 3(4), 101-109.

Borges, C. M., \& Sanches-Neto, L. (2014). Compartilhando a análise de práticas pedagógicas na educação física: Perspectivas colaborativas. Instrumento - Revista de Estudo e Pesquisa em Educação, 16(2), 231-248.

Brasil. (1998). Parâmetros Curriculares Nacionais: Terceiro e quarto ciclos: Apresentação dos temas transversais. Brasília: Ministério da Educação.

Darido, S. C., \& Rangel, I. C. (2011). Educação física na escola: Implicações para a prática pedagógica. ( $\left.2^{\mathrm{a}} \mathrm{ed}\right)$. Guanabara Koogan.

França, J. F., \& Freire, E. S. (2009). Educação física e currículo: Os conteúdos selecionados pelos professores para o ensino fundamental. Revista Mackenzie de Educação Física e Esporte, 8(2), 89-102.

Ferreira, E. C., Oliveira, J. J., Reis, M. B., Lima, R. G., Venâncio, L., \& Sanches-Neto, L. (2018). Os desafios pedagógicos das demandas ambientais na perspectiva de estudantes de educação física. Revista Brasileira de Educação Física Escolar, 4(1), 134-157.

Gallahue, D. L. (2002). A classificação das habilidades de movimento: Um caso para modelos multidimensionais. Revista da Educação Física/UEM, 13(2), 105-111.

Goellner, S. V. (2000). A educação física e a construção de imagens de feminilidade no Brasil dos anos 30 e 40. Movimento, 13, 61-70.

Inácio, H. L., Cauper, D. A., Silva, L. A., \& Morais, G. G. (2016). Práticas corporais de aventura na escola: Possibilidades e desafios - reflexões para além da base nacional comum curricular, Motrivivência, 28(48), 168-187.

Laplantine, F. (2003). Aprender antropologia. Brasiliense.

Marinho, A., \& Schwartz, G. M. (2005). Atividades de aventura como conteúdo da educação física: Reflexões sobre seu valor educativo. Lecturas: Educación Física y Deportes, 10(88), 1-8.

Moura, L. D., Santana, M. A., Júnior, J. F., Silva, J. C., Lima, J. M., Araújo, J. G., \& Sousa, C. B. (2018). Dialogando sobre o ensino da educação física: Práticas corporais de aventura na escola. CRV.

Pereira, W. P., \& Almeida, A. M., \& Gaspari, F. A. (2014). Esportes radicais, de aventura e ação: O conteúdo dos ensinos formal e não formal e os desafios de formação e prática do profissional de educação física. Conexões - Revista da 
Faculdade de Educação Física da Unicamp, 12(3), 159-168.

Pimentel, G. G. (2013). Esportes na natureza eatividades de aventura: Uma terminologia aporética. Revista Brasileira de Ciências do Esporte, 35(3), 687-700.

Porretti, M., Pessoa, F., \& Assis, M. (2020). Montanhismo: Um relato de experiência da interdisciplinaridade entre educação física e geografia. Caderno de Educação Física e Esporte, $\quad 18(1), \quad 61-67$. http://dx.doi.org/10.36453/23185104.2020.v18.n1.p61

Rocha, L. L. (2017). Surfando para a vida: Um estudo sobre o papel do surfe como prática pedagógica libertadora (Mestrado). Universidade Federal do Ceará.

Rocha, L. L., Venâncio, L., Sanches-Neto, L., Farias, A. N., \& Brasil, R. A. (2018). Os desafios pedagógicos das demandas ambientais na perspectiva de professores(as) de educação física. Revista Brasileira de Educação Física Escolar, 3(3), 126-147.

Rodrigues, L. H., \& Darido, S. C. (2006). Educação física escolar e meio ambiente: Reflexões e aplicações pedagógicas. Efdeportes, 11(100).

http://www.efdeportes.com/efd100/ma.htm.

Rosa, P. F., \& Carvalhinho, L. A. (2012). A educação ambiental e o desporto na natureza: Uma reflexão crítica sobre os novos paradigmas da educação ambiental e o potencial do desporto como metodologia de ensino. Movimento, 18(3) 259280.

Sanches-Neto, L. (2017). Sistematização dos processos de ensino e aprendizagem: Convergência entre conteúdos temáticos e objetivos da educação física escolar. In: T. Okimura-Kerr, C. Ulasowicz, L. Venâncio, \& L. Sanches-Neto (Orgs), Educação física no ensino fundamental I: Perspectivas de sistematização dos blocos de conteúdos temáticos (pp. 13-34). CRV.

Sanches-Neto, L., \& Betti, M. (2008). Convergência e Integração: Uma proposta para a educação física de $5^{\circ}$ a $8^{\circ}$ série do ensino fundamental. Revista Brasileira de Educação Física e Esporte, 22(1), 5-23.

Sanches-Neto, L., Conceição, W. L., Okimura-Kerr, T., Venâncio, L., Vogel, A. J. Z., Franca, A. L., Corsino, L. N., Rodrigues, J. C. R., \& Freitas, T. P. (2013). Demandas ambientais na educação física escolar: Perspectivas de adaptação e de transformação. Movimento, 19(4), 309-330.

Santos, P. M., Manfroi, M. N., Figueiredo, J. P., Brasil, V. Z., \& Marinho, A. (2015). Formação profissional e percepção de competências de estudantes de educação física: Uma reflexão a partir da disciplina de esportes de aventura e na natureza. Revista da Educação Física/UEM, 26(4), 529-540.

Tahara, A. K., \& Darido, S, C. (2016). Práticas corporais de aventura em aulas de educação física na escola. Conexões, 14(2), 113-136.

Tahara, A. K., \& Carnicelli Filho, S. (2012). A presença das atividades de aventura nas aulas de educação física. Arquivos de Ciências do Esporte, $1(1), 60-66$. 


\title{
Técnicos de Desporto de Natureza: Contributos para o Entendimento das Problemáticas do Setor
}

\begin{abstract}
Ricardo Melo $^{1,2}$, Diogo Leite ${ }^{1}$
${ }^{1}$ Escola Superior de Educação de Coimbra - Instituto Politécnico de Coimbra (ESEC-IPC)

${ }^{2}$ Centro de Estudos Sociais da Universidade de Coimbra (CES-UC)

Palavras-chave

Associação de

técnicos;

Desportos de

Natureza;

Esquema de

formação;

Regulação e

certificação;

Sistema de

monitorização e

Avaliação.

\section{RESUMO:}

O objetivo deste artigo é apresentar o perfil sociodemográfico e profissional dos técnicos de desportos de natureza que trabalham na Região de Coimbra, identificar as principais problemáticas do setor e da profissão sentidas por estes técnicos, e apresentar recomendações estratégias para a melhoria do setor. Para isso desenvolveu-se um estudo de caso, cuja recolha de dados se efetuou através da aplicação de 30 entrevistas semiestruturadas a uma amostra de técnicos que colaboravam com Empresas de Animação Turística sediadas na Região de Coimbra, complementada com seis meses de observação participante numa dessas empresas da referida região. Os técnicos inquiridos são indivíduos jovens, solteiros, do sexo masculino, com qualificações académicas elevadas. Os técnicos colaboram a tempo parcial nas empresas com as quais colaboram, com baixa remuneração advinda da execução das diversas funções que executam (técnicas, logísticas, secretariado, e de gestão), trabalhando por isso noutras atividades profissionais ao longo do ano. Ao analisar as principais problemáticas identificadas neste estudo sugere-se a criação de uma associação de técnicos de desportos de natureza, a introdução de um esquema de formação, a produção de legislação relacionada com a regulação do acesso à profissão, e a implementação de um sistema de monitorização e avaliação da competência e da performance dos técnicos.
\end{abstract}

\section{Keywords}

Association of

technicians;

Nature sports;

Training scheme;

Regulation and

certification;

Monitoring and

evaluation system

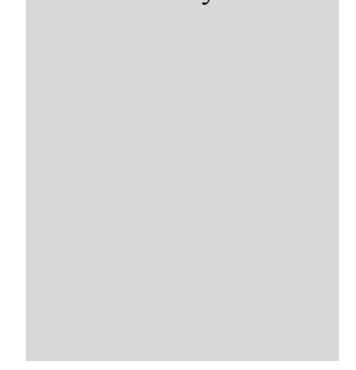

Nature sports technicians: Contributions to understanding the sector problem

ABSTRACT:

The purpose of this article is to present the sociodemographic and professional profile of nature sports technicians who work in the Region of Coimbra, to identify the main problems of the sector and the profession felt by these technicians, and to present strategic recommendations for the improvement of the setor. For this, a case study was developed, whose data collection was carried out through the application of 30 semi-structured interviews to a sample of technicians who collaborated with touristic animation companies based in the Region of Coimbra, complemented with six months of participant observation in one of these companies of the referred region. The interviewed technicians are young, single, male individuals, with high academic qualifications, who collaborate in part-time in the companies with which they collaborate, with low remuneration resulting from the performance of the various functions they perform (technical, logistical, secretarial, and management), therefore working on other professional activities throughout the year. When analyzing the main problems identified in this study, the creation of an association of sports technicians of nature and tourist entertainment, the introduction of a training scheme, the production of legislation related to the regulation of access to the profession, and the implementation of a system for monitoring and evaluating the competence and performance of technicians are suggested. 
Técnicos de desportos de natureza: contributos para o entendimento das problemáticas do setor

A designação 'desportos de natureza' emergiu no final do século XX (Bessy \& Mouton, 2004; Melo \& Gomes, 2014, 2017a;) como um dos muitos termos usados (desportos de ação, desportos de aventura, desportos alternativos, desportos californianos, desportos radicais, 'lifestyle sports', novos desportos, desportos ao ar livre, desportos de risco, entre outros) que têm o potencial de desafiar os participantes de uma forma inovadora e oferecem uma alternativa às formas tradicionais de ver, praticar e entender o desporto (Melo, Van Rheenen, \& Gammon, 2020a; Wheaton, 2004). Os desportos de natureza compreendem um grupo de atividades desportivas desenvolvidas e experienciadas em áreas naturais ou rurais, que variam de práticas formais a informais, e que podem contribuir para o desenvolvimento sustentável local (Melo \& Gomes, 2017a), embora as supostas ligações entre a participação em desportos de natureza e uma ética genuína de cuidar do meio ambiente sejam questionadas (Booth, 2020). Estas práticas são realizadas em diversos contextos naturais, incluindo no espaço aéreo (parapente e asadelta, etc.), terrestre (BTT, escalada, pedestrianismo, etc.) e aquático (caiaque, vela, surf, windsurf, etc.) (Melo \& Gomes, 2016b), apresentando um conjunto de características distintivas em relação a outros desportos, nomeadamente, são atividades: (a) baseadas na natureza; (b) sustentáveis; (c) de risco e aventura; (d) hedonísticas e não competitivas; (e) autónomas e individualistas; e f) de participação ativa (Melo, et al., 2020a).

$\mathrm{O}$ aumento da visibilidade cultural dos desportos de natureza atraiu um número significativo de participantes de todas as geografias (Melo, Van Rheenen, \& Gammon, 2020b; Rinehart \& Sydnor, 2003; Wheaton, 2004, 2013). Embora a estrutura informal e itinerante dos desportes de natureza torne difícil medir com precisão os níveis de participação (Melo, 2013; Gomes, Gustavo, Melo, \& Pedragosa, 2017), vários exemplos demonstram que o crescimento da participação nos desportos de natureza tem sido consistente e generalizado no mundo, superando o aumento da maioria dos desportos tradicionais em muitos países ocidentais (Brymer \& Schweitzer, 2017; Outdoor Foundation 2018; Melo, 2013; MSJS, 2015; Sports England and Outdoor Industries Association, 2015; Wheaton, 2013). O envolvimento nestes desportos não é apenas uma moda passageira, mas um sinal dos tempos em que as pessoas procuram uma nova forma de definir as suas vidas e escapar de um crescente modo de vida regulamentado e higienizado (Houge MacKenzie \& Brymer, 2020). A importância dos desportos de natureza é também evidenciada pela crescente atenção dada por outros setores, incluindo o lazer, o turismo, o meio ambiente, a saúde e a educação (Melo, et al., 2020a).
A visibilidade dos desportos de natureza foi potenciada pelos meios de comunicação social, através de programas e transmissões de TV, revistas especializadas, filmes e sites da Internet (Wheaton, 2013). Os exemplos mais proeminentes são os $X$ Games da ESPN, que comandaram uma audiência global de 50 milhões em 2003 (Wheaton, 2013) e o filme 'Free Solo', vencedor do Óscar 2019 de Melhor Documentário (Melo, et al., 2020b). O crescimento e o desenvolvimento de algumas atividades desportivas na natureza levaram a um processo de desportivização (Aubel, Hoibian, \& Defrance, 2002; Suchet, 2011), resultando na incorporação dessas atividades nos Jogos Olímpicos de Verão e Inverno (Melo, et al., 2020b). A mediatização de alguns desses desportos de natureza ajudou a criar celebridades globais como Shaun White no snowboard, Kelly Slater no surf e, mais recentemente, Alex Honnold na escalada (Melo, et al., 2020a) que, como outras celebridades desportivas, transcendem as suas subculturas e ocupam e habitam o espaço mediático nacional e internacional (Wheaton, 2013).

A rápida expansão dos desportos de natureza tem sido acompanhada por uma fragmentação cultural que suporta um novo perfil de participação (Melo, et al., 2020b; Wheaton 2013). Inicialmente, as atividades desportivas na natureza eram praticadas predominantemente por jovens do sexo masculino, com nível educativo superior, com empregos altamente qualificados e, consequentemente, com altos níveis de capital económico (Dolnicar \& Fluker 2003a; Barbieri \& Sotomayor, 2013; Portugal et al. 2017; Melo \& Gomes 2017b) e social (Pociello 1981). Hoje, a indústria dos desportos de natureza testemunhou uma mudança demográfica, com o aumento das taxas de participação nas diversas gerações (Brymer \& Schweitzer, 2017), criando assim novos nichos de mercado lucrativos que incluem não apenas jovens adolescentes, mas também raparigas, mulheres e homens adultos, e uma população em envelhecimento, que apresentam uma ampla gama de interesses e experiências (Brymer \& Schweitzer 2017; Melo, 2017; Melo, et al., 2020b; Wheaton 2016). Todavia, em Portugal, os praticantes de desportos de natureza são ainda maioritariamente jovens, com qualificações académicas ao nível do ensino superior, com profissões altamente qualificadas e com rendimentos acima da média nacional (Melo, 2013; Melo \& Gomes, 2017b).

$\mathrm{O}$ aumento e a diversidade da participação e da procura por desportos de natureza tem também evidenciado um aumento global da oferta. Um número significativo de projetos relacionados com estas atividades foi criado recentemente em Portugal, originando novos empregos e estimulando o desenvolvimento sustentável local (Gomes, Pedragosa, Melo, \& Gustavo, 2017; Melo, 2013; Melo \& Gomes, 2017a; 2017b). Nesse sentido, foram identificados cinco tipos diferentes organizações 
promotoras dos desportos de natureza (OPDN) relacionadas com a sua oferta, e que apresentam igualmente diferentes tipos de enquadramento técnico (Melo \& Gomes, 2017c), nomeadamente:

i. Empresas generalistas - organizações empresariais com uma diversidade de oferta (geralmente cinco ou mais atividades dos desportos na natureza), principalmente baseado em canoagem, pedestrianismo e multiactividades;

ii. Empresas especializadas - organizações empresariais baseadas na oferta de duas ou três atividades desportivas na natureza, divididas em quatro especializações: a) atividades de surfing (e.g., bodyboard, skimming, e surf), embora também possam oferecer outras atividades, como o BTT; b) atividades de vento/água (e.g., kitesurf, vela, e windsurf); c) atividades de mergulho, embora também possam oferecer outras atividades; e d) atividades de montanha (e.g., montanhismo, pedestrianismo, escalada, BTT e voo livre);

iii. Clubes desportivos tradicionais - associações sem fim lucrativo baseados principalmente na competição desportiva e na organização de eventos competitivos (e.g., BTT, orientação e canoagem);

iv. Clubes de formação desportiva - associações sem fim lucrativo baseadas principalmente na oferta de cursos de formação de praticantes para os membros (e.g., montanhismo, escalada, canyoning, mergulho e canoagem);

v. Clubes de recreação desportiva - associações sem fim lucrativo baseadas principalmente na oferta de atividades recreativas (e.g., pedestrianismo, BTT, montanhismo e canoagem).

O governo português, reconhecendo a importância das atividades turísticas que são desenvolvidas nas áreas naturais, seguindo a Resolução do Conselho de Ministros n. ${ }^{\circ}$ 102/96, de 08 de julho (Revogado), criou o Programa Nacional do Turismo de Natureza (PNTN), aplicável na Rede Nacional de Áreas Protegidas (Presidência do Conselho de Ministros, 1996), regulado mais tarde pelo Decreto-Lei n. ${ }^{\circ}$ 47/99, de 16 de fevereiro, alterado pelo Decreto-Lei n. ${ }^{\circ}$ 56/2002, de 11 de março (Ministério da Economia, 2002a). Em 1999, o governo criou o Programa Desporto de Natureza em Áreas Protegidas através do Decreto Regulamentar n. ${ }^{\circ}$ 18/99, de 27 de agosto, alterado pelo Decreto Regulamentar n. ${ }^{\circ} 17 / 2003$, de 10 de outubro (Revogado) que visou regulamentar a animação ambiental nas modalidades de animação, interpretação ambiental e desporto de natureza nas áreas protegidas (Ministério das Cidades Ordenamento do Território e Ambiente, 2003). Por sua vez, através do Decreto-Lei n. ${ }^{\circ}$ 204/2000, de 1 de setembro, alterado pelo Decreto-Lei ${ }^{\circ} 108 / 2002$, de 16 de abril (Revogado) foi estabelecido pela primeira vez o enquadramento legal das atividades de animação turística, que inclui a oferta dos desportos de natureza (Ministério da Economia, 2002b). Constatando a desatualização do diploma anterior, quase uma década depois, através do Decreto-Lei $\mathrm{n}^{\circ}$ 108/2009, de 15 de maio, alterado pelo Decreto-Lei n. ${ }^{\circ} 95 / 2013$, de 19 de julho e pelo Decreto-Lei n. ${ }^{\circ}$ $186 / 2015$, de 3 de setembro, foi estabelecido um novo regime jurídico que define as condições de acesso e de exercício da atividade das Empresas de Animação Turística (EAT) e dos Operadores MarítimoTurísticos (Ministério da Economia, 2015). Este diploma, para além de congregar o regime de acesso à atividade, independentemente da modalidade de animação turística exercida, cria o Registo Nacional dos Agentes de Animação Turística (RNAAT), regulado pela Portaria n. ${ }^{\circ} 1087 / 2010$, de 22 de outubro (Ministério da Economia da Inovação e do Desenvolvimento, 2010), contendo uma relação atualizada dos agentes a operar no mercado. O RNAAT inclui igualmente as organizações que exerçam as atividades na rede das áreas protegidas, reconhecidas como Turismo de Natureza, que devem respeitar o código de conduta estabelecido pela Portaria n. ${ }^{\circ}$ 651/2009, de 12 de junho (Ministério do Ambiente do Ordenamento do Território e do Desenvolvimento Regional e da Economia e da Inovação, 2009).

A articulação entre Desporto e outros setores, nomeadamente com o Ambiente e o Turismo, foi também consagrada pela publicação da Lei n. $^{\circ}$ 30/2004, de 21 de julho (Revogado) - Lei de Bases do Desporto (Assembleia da República, 2004) e mais tarde pela Lei n. ${ }^{\circ}$ 5/2007 de 16 de Janeiro - Lei de Bases da Atividade Física e do Desporto (Assembleia da República, 2007). Todavia, no que se refere à formação de técnicos denota-se uma ausência de articulação entre os diversos setores, salientando-se inclusivamente a ausência de legislação que regule o acesso à profíssão dos técnicos dos desportos de natureza que laboram no setor do turismo. Por sua vez, no que se refere ao setor do Desporto, foi criado o Programa Nacional de Formação de Treinadores, que inclui o plano de formação de treinadores de modalidades dos desportos de natureza com carácter competitivo (e.g., canoagem, escalada, orientação, surf, etc.). Em consonância com o determinado no Regime Jurídico da Formação Desportiva no Quadro da Formação Profissional, estabelecido pelo DecretoLei n. ${ }^{\circ}$ 407/99, de 15 de outubro (Presidência do Conselho de Ministros, 1999), e com o Decreto-Lei n. ${ }^{\circ} 396 / 2007$, de 31 de dezembro, que estabelece o Regime Jurídico do Sistema Nacional de Qualificações e define as estruturas que asseguram o seu funcionamento (Ministério do Trabalho e da Solidariedade Social, 2007), o Decreto-Lei n. ${ }^{\circ} 248$ A/2008, de 31 de dezembro (Presidência do Conselho de Ministros, 2008), veio definir o regime de acesso e do exercício da atividade de treinador/a de desporto, que, em 28 de agosto de 2012, foi revogado pela Lei n. ${ }^{\circ} 40 / 2012$, recentemente alterada pela Lei $n^{\circ}$ 
106/2019, de 06 de setembro (Assembleia da República, 2019).

Com o aumento da procura e da oferta por desportos de natureza, também foram surgindo preocupações, especialmente em relação ao risco e à segurança (Melo \& Mendes, 2011; Pimentel \& Melo, 2013), e à sustentabilidade dos espaços e das comunidades onde estas atividades decorrem (Melo \& Gomes, 2016a; 2016b), particularmente quando estas atividades decorrem em ambientes naturais e socioculturais sensíveis (Orams, 1999). Uma oportunidade para reduzir estas problemáticas é através do recurso a técnicos especializados em desportos de natureza (Melo \& Leite, 2020; Pereira \& Mykletun, 2012). Os técnicos são muito importantes porque são a interface entre as OPDN, as atividades oferecidas, o destino e os participantes/turistas dos desportos de natureza. Estes são os funcionários da linha da frente, responsáveis pela impressão geral e satisfação com o serviço oferecido pelas organizações, proporcionando uma experiência de qualidade nos territórios onde são realizadas as atividades, sem causar danos ecológicos e sociais intoleráveis (Jensen, 2010; Melo \& Gomes, 2017c; Randall \& Rollins, 2009; Weiler \& Davies, 1993).

Os técnicos de desportos de natureza foram inicialmente contratados como guias, para encontrar caminhos nas montanhas ou para recursos naturais (Cohen, 1985; Rokenes, Schumann, \& Rose, 2015). No entanto, o papel dos técnicos de desportos de natureza é complexo e multidimensional porque, à medida que as OPDN evoluíram, também o papel dos técnicos evoluiu gradualmente, adaptando-se a novas procuras, tendências e configurações (Melo \& Leite, in 2020; Rokenes, Schumann, \& Rose, 2015).

Diferentes aspetos relacionados com os técnicos dos desportos de natureza foram estudados em várias disciplinas, como marketing, educação na natureza, lazer, recreação, psicologia e sociologia (Rokenes, Schumann, \& Rose, 2015). A literatura sobre esta temática identifica uma ampla diversidade de papéis. Estes técnicos foram chamados de prestadores de serviços (Arnould \& Price, 1993; Wong \& Lee, 2012), coreógrafos (Beedie, 2003), intérpretes culturais (Pereira, 2005), conservadores ambientais (Curtin, 2009; Ormsby \& Mannie, 2006), especialistas em atividades (Pomfret, 2011), planeadores (Pomfret, 2011) e contadores de histórias (Mathisen, 2012). Também foram descritos como intermediários da cultura, artistas, fornecedores de informações, líderes, mediadores, mentores, fontes de conhecimento, pais substitutos e desbravadores (Rokenes, Schumann, \& Rose, 2015). Estas descrições contribuem para o entendimento da complexidade e alteração da função dos técnicos ao longo do tempo.

A partir de descrições e categorizações anteriores, Melo e Leite (2020) dividiram o papel dos técnicos de desportos de natureza em duas esferas: (a) esfera de liderança, dividida em papel instrumental e social
(Cohen, 1985) e, (b) esfera de desenvolvimento sustentável, dividida em três dimensões - ambiental, económica e sociocultural (Cohen, 1985; Pereira \& Mykletun, 2012; Weiler \& Davis, 1993).

Considerando a importância dos técnicos no setor dos desportos de natureza, a investigação destes atores chave é diminuta em termos globais, e menor ainda em Portugal. Portanto, este estudo tem como objetivo:

i) Caracterizar o perfil sociodemográfico e socioprofissional dos técnicos de desportos de natureza que trabalham na Região de Coimbra;

ii) Identificar as principais problemáticas do setor e da profissão sentidas por estes técnicos.

Apresentar recomendações estratégias para a melhoria do setor, em especial no que diz respeito à profissão de técnico de desportos de natureza.

Para isso desenvolveu-se um estudo de caso na Região Centro de Portugal, tal como se apresenta de seguida.

\section{Método}

Este estudo de caso adotou uma abordagem qualitativa e descritiva (Yin, 1989). É considerado o método mais apropriado a adotar devido à natureza exploratória e à limitada informação disponível sobre este tópico. A área do estudo é a Comunidade Intermunicipal (CIM) da Região de Coimbra, composta por 19 municípios, ocupando uma área de $3900 \mathrm{~km}^{2}$. De acordo com o Registo Nacional de Turismo, em 2017, estavam estabelecidas 58 EAT nesta região (Turismo de Portugal, 2017).

A recolha dos dados foi realizada através da aplicação de entrevistas semiestruturadas a uma amostra constituída por conveniência. A estratégia de amostragem foi entrevistar o maior número possível de técnicos de desportos de natureza que tinham colaborado com EAT sediadas na Região de Coimbra, durante o ano de 2017, considerando-se uma representatividade por género, anos de experiência profissional, e tipo de dedicação (exclusiva ou não). Excluíram-se deste estudo os técnicos de desportos de natureza que trabalhavam exclusivamente noutros contextos, como os treinadores em clubes desportivos e os técnicos em clubes e associações desportivas e recreativas, entre outros. Aplicaram-se, assim, 30 entrevistas semiestruturadas, abrangendo: 25 homens e cinco mulheres; 16 técnicos com menos de cinco anos de experiência, nove técnicos com seis a 10 anos de experiência e 10 técnicos com mais de 10 anos de experiência; 13 técnicos que trabalhavam exclusivamente em desportos de natureza, e 17 que tinham outro emprego. $\mathrm{O}$ guião de entrevista contemplava um conjunto de 40 perguntas abertas. Cada entrevista, que teve a duração de aproximadamente uma hora, foi gravada e posteriormente transcrita na íntegra. 
Como forma de triangular os dados foi também efetuada, pelo segundo autor, seis meses (entre outubro de 2016 e Março de 2017) de observação participante numa EAT generalista (Melo \& Gomes, 2017c), sediada na região em estudo. Baseado na perspetiva de "insider" explicada por Jorgensen (1989), o segundo autor trabalhou durante o referido período na EAT, ajudando os técnicos de desportos de natureza a reconhecer locais para organizar as atividades, organizar materiais essenciais, montar os equipamentos e orientar algumas atividades de desportos de natureza, como canyoning, canoagem, escalada, pedestrianismo e manobras de corda. Essa foi uma forma de interagir com os técnicos da EAT, de ganhar a sua confiança e observar o seu trabalho (Carnicelli, 2010).

Os dados recolhidos através das entrevistas e da observação participante foram analisados por meio de análise de conteúdo, conforme sugerido por Bardin (2006). Os dados foram revistos de forma sistemática e cuidadosa antes de identificar os elementos, padrões e tendências comuns. Além disso, a codificação foi realizada de acordo com os critérios especificados por Strauss e Corbin (1998), tais como, neutralidade, frequência, facilidade de referência a outras categorias e possuir implicações claras para a teoria formal. A interpretação foi baseada não apenas na literatura, mas também na experiência do segundo autor durante o trabalho de campo e na experiência pessoal do primeiro autor na área, como professor, supervisor de estágios e técnico de desportos de natureza, cujos resultados se apresentam de seguida.

\section{Resultados}

Esta secção subdivide-se em dois grandes blocos. Inicialmente apresenta-se o perfil sociodemográfico e profissional dos técnicos inquiridos, e de seguida apresentam-se as problemáticas que foram identificadas pelos inquiridos em relação ao setor e à profissão de técnico de desporto de natureza.

\section{Perfil sociodemográfico e Socioprofissional dos técnicos dos desportos de natureza}

A distribuição dos técnicos dos desportos natureza da nossa amostra indica que $83.3 \%$ dos inquiridos são homens e $16.7 \%$ são mulheres. A média de idade dos entrevistados é de 29.4 anos ( \pm 6.4), com predominância de respondentes abaixo dos 30 anos (67.7\%). Quase todos (80\%) são solteiros e uma pequena proporção (13.3\%) é casada. Uma grande parte $(40 \%)$ vive com os pais e irmãos, e uma pequena parte $(30 \%)$ tem filhos. A maioria $(60.1 \%)$ dos inquiridos afirmou ter atingido a qualificação académica ao nível do ensino superior: $36.7 \%$ concluíram a licenciatura; $16.7 \%$ obtiveram uma pósgraduação; e $6.7 \%$, um mestrado. Os restantes inquiridos concluíram o ensino médio - $12^{\circ}$ ano (26.7\%) ou obtiveram o ensino pré-superior - grau de especialização tecnológica (13.3\%). Os participantes do estudo são técnicos de desportos de natureza que vivem principalmente na região de Coimbra: a maioria $(66.7 \%)$ deles viaja menos de $10 \mathrm{~km}$ até a sede da EAT e, em média, $13.2 \mathrm{~km}$ para ir trabalhar.

Tabela 1. Perfil sociodemográfico dos técnicos de desportos de natureza

\begin{tabular}{|c|c|c|}
\hline Indicadores & $n$ & $\%$ \\
\hline \multicolumn{3}{|l|}{ Sexo $(n=30)$} \\
\hline Masculino & 25 & 83.3 \\
\hline Feminino & 5 & 16.7 \\
\hline \multicolumn{3}{|l|}{ Idade $(n=30)$} \\
\hline Menos de 21 anos & 5 & 16.7 \\
\hline Entre 21 e 30 anos & 15 & 50.0 \\
\hline Entre 31 e 40 anos & 5 & 16.7 \\
\hline Entre 41 e 50 anos & 4 & 13.3 \\
\hline Mais de 50 anos & 1 & 3.3 \\
\hline \multicolumn{3}{|l|}{ Estado civil $(n=30)$} \\
\hline Solteiro & 24 & 80.0 \\
\hline Casado & 4 & 13.3 \\
\hline Divorciado & 2 & 6.7 \\
\hline \multicolumn{3}{|l|}{ Com quem vive $(n=30)$} \\
\hline Sozinha/o & 6 & 20.0 \\
\hline Pais e irmãos & 13 & 43.3 \\
\hline Namorado/a & 5 & 16.7 \\
\hline Mulher/marido e filhos & 5 & 16.7 \\
\hline Irmã/ão & 1 & 3.3 \\
\hline \multicolumn{3}{|l|}{ Filhos $(n=30)$} \\
\hline Sim & 9 & 30.0 \\
\hline Não & 21 & 70.0 \\
\hline \multicolumn{3}{|c|}{ Habilitações académicas $(n=30)$} \\
\hline $12^{\circ}$ ano completo & 8 & 26.7 \\
\hline CET & 4 & 13.3 \\
\hline Licenciatura & 11 & 36.7 \\
\hline Pós-graduação & 5 & 16.7 \\
\hline Mestrado & 2 & 6.7 \\
\hline \multicolumn{3}{|c|}{ Distância para local de trabalho $(n=30)$} \\
\hline Menos de $11 \mathrm{~km}$ & 20 & 66.7 \\
\hline Entre 11 e $20 \mathrm{~km}$ & 5 & 16.7 \\
\hline Mais de $20 \mathrm{~km}$ & 5 & 16.7 \\
\hline
\end{tabular}

Os técnicos inquiridos trabalham a tempo integral (43.3\%) na área dos desportos de natureza, apesar de a maioria $(56.7 \%)$ trabalhar em regime de tempo parcial $(50 \%)$, verificando-se que estes últimos procuram outras profissões fora desta área uma vez que não conseguem trabalhar nela a full-time. Trabalham principalmente $(56.7 \%)$ em exclusividade para uma EAT ou como free-lancers (43.3\%).

Os técnicos de desportos de natureza desempenham diferentes funções nas EAT com as quais colaboram, principalmente, técnicas (96.7\%), logísticas (66.7\%), secretariado (40. 0\%), e de gestão (36.7\%). Estes dados foram também verificados durante a observação participante, já que os técnicos da EAT analisada exerciam diversas funções, tais como, técnicas, logísticas e secretariado, sendo estes os responsáveis pela promoção dos serviços da empresa, pela organização e planeamento das atividades e operacionalização das mesmas. 
A formação dos técnicos inquiridos é principalmente académica $(66.7 \%)$ - nas áreas do turismo (40\%) e desporto $(26.7 \%)$-, ou através de cursos de formação especializada $(20,0 \%)$, sendo que apenas três $(10 \%)$ dos técnicos não têm nenhum tipo de formação para trabalhar nesta área. Em relação aos rendimentos, apenas cinco $(16.7 \%)$ dos técnicos inquiridos ganha mais de $€ 7000$ líquidos anualmente. Para além disso, considerando o número de horas de trabalho por dia, o número de dias de trabalho por semana, estima-se que os técnicos de desportos de natureza em Portugal aufiram em média $3.5 €$ por hora, valor muito baixo considerando, por um lado, as enormes responsabilidades em garantir a segurança e proporcionar uma experiência de qualidade entre os participantes/turistas desportivos, e por outro a alta qualificação obtida pelos mesmos. De acordo com as entrevistas e a observação participante, todos os técnicos poderiam operacionalizar pelo menos uma atividade dos desportos de natureza.

Tabela 2A. Perfil socioprofissional dos técnicos de desportos de natureza

\begin{tabular}{|c|c|c|}
\hline Indicadores & $n$ & $\%$ \\
\hline \multicolumn{3}{|c|}{ Vínculo contratual e época de trabalho } \\
\hline $\begin{array}{l}\text { Full time - ano } \\
\text { inteiro }\end{array}$ & 13 & 43.3 \\
\hline Full time - sazonal & 2 & 6.7 \\
\hline $\begin{array}{l}\text { Part time - ano } \\
\text { inteiro }\end{array}$ & 4 & 13.3 \\
\hline Part time - sazonal & 11 & 36.7 \\
\hline \multicolumn{3}{|l|}{ Vínculo laboral } \\
\hline Exclusividade & 17 & 56.7 \\
\hline Free-lancers & 13 & 43.3 \\
\hline \multicolumn{3}{|l|}{ Funções na EAT } \\
\hline Técnicas & 29 & 96.7 \\
\hline Logísticas & 20 & 66.7 \\
\hline Secretariado & 12 & 40.0 \\
\hline Gestão & 11 & 36.7 \\
\hline \multicolumn{3}{|c|}{ Formação para o exercício da profissão } \\
\hline $\begin{array}{l}\text { Formação } \\
\text { académica em } \\
\text { Turismo }\end{array}$ & 12 & 40.0 \\
\hline $\begin{array}{l}\text { Formação } \\
\text { académica em } \\
\text { Desporto }\end{array}$ & 8 & 26.7 \\
\hline $\begin{array}{l}\text { Cursos de formação } \\
\text { especializada }\end{array}$ & 6 & 20.0 \\
\hline $\begin{array}{l}\text { Experiência } \\
\text { profissional }\end{array}$ & 1 & 3.3 \\
\hline Sem formação & 3 & 10.0 \\
\hline
\end{tabular}

Tabela 2B. Perfil socioprofissional dos técnicos de desportos de natureza

\begin{tabular}{|c|c|c|}
\hline Indicadores & $n$ & $\%$ \\
\hline \multicolumn{3}{|c|}{ Horário médio de trabalho semanal } \\
\hline 20 horas & 3 & 10.0 \\
\hline 30 horas & 1 & 3.3 \\
\hline 35 horas & 9 & 30.0 \\
\hline 40 horas & 14 & 46.7 \\
\hline 60 horas & 3 & 10.0 \\
\hline \multicolumn{3}{|l|}{ Rendimentos anuais na EAT } \\
\hline Menos de $1000 €$ & 2 & 6.7 \\
\hline Entre 1000 e $3000 €$ & 12 & 40.0 \\
\hline Entre 3001 e $5000 €$ & 2 & 6.7 \\
\hline Entre 5001 e $7000 €$ & 9 & 30.0 \\
\hline Entre 7001 e $9000 €$ & 5 & 16.7 \\
\hline \multicolumn{3}{|l|}{ Remuneração por hora } \\
\hline Menos de $2 €$ & 2 & 6.7 \\
\hline Entre 2 e $3.99 €$ & 21 & 70.0 \\
\hline Entre 4 e $5.99 €$ & 5 & 16.7 \\
\hline Entre 6 e $7.99 €$ & 2 & 6.7 \\
\hline
\end{tabular}

Problemáticas do setor dos desportos de natureza e dos técnicos

A perceção dos inquiridos sobre a qualidade dos técnicos de desportos de natureza é, na generalidade, positiva: um terço $(33.3 \%)$ julga que os técnicos apresentam uma qualidade razoável, a maioria (60\%) considera que os técnicos apresentam boa qualidade, enquanto uma pequena minoria $(6.7 \%)$ afirma que os técnicos possuem muito boa qualidade. Para que a qualidade dos técnicos seja melhor, os inquiridos referem que é essencial que estes obtenham boa formação avançada, nomeadamente, uma licenciatura (30\%) ou um CET (30\%) especializado nesta área.

Não obstante a perceção positiva sobre a qualidade dos técnicos e a evolução positiva da legislação produzida nos últimos anos, em especial relativa à animação turística, os técnicos inquiridos salientam algumas problemáticas no setor e na profissão de técnico de desportos de natureza.

Em relação ao setor, para $36.7 \%$ dos inquiridos, a principal problemática apontada está relacionada com a falta de legislação, regulamentação e cerificação dos técnicos. De acordo com os inquiridos, este é um aspeto crucial na medida em que obrigaria todos os técnicos a possuírem formação para o exercício das suas funções, melhorando desta forma a qualidade dos serviços oferecidos pelas EAT (e outras OPDN). Outras problemáticas identificadas em relação ao setor foram a inexistência de formação específica para o exercício da profissão $(20 \%)$, e a falta de inspeção/fiscalização do trabalho dos técnicos $(16.7 \%)$. Os inquiridos centram-se também noutro tipo de problemáticas que o setor enfrenta, tal como, a sazonalidade da procura (23.3\%), a falta de apoios financeiros $(16.7 \%)$ e a falta de divulgação dos serviços $(13.3 \%)$.

No que diz respeito às problemáticas associadas ao exercício da profissão dos técnicos de deportos de 
natureza, e considerando que a maioria gostaria de exercer a profissão ao longo de todo o ano, verificase que a sazonalidade do trabalho é o problema apontada por mais inquiridos $(60 \%)$, derivado obviamente pela sazonalidade da procura. Outros problemas identificados pelos técnicos foram os baixos rendimentos obtidos no exercício desta profissão $(6.7 \%)$, e a falta de exigência de formação de alguns dos técnicos (13.3\%), o que não permite uma diferenciação na carreira profissional.

Apesar de a formação ser considerada pelos inquiridos como um fator de grande importância para um técnico de desportos de natureza verifica-se ainda que alguns (13.3\%) dos inquiridos não possui qualquer tipo de formação. No entanto, ao comparar a formação inicial destes técnicos com a formação atual, denota-se uma evolução positiva, na medida em que $36.7 \%$ dos inquiridos não apresentava qualquer tipo de formação quando iniciou as suas funções numa EAT e que, atualmente, a grande maioria (86\%) já obteve formação na área.

Uma vez que nem todos os técnicos apresentam formação adequada para o exercício das suas funções, existem diversas EAT que fornecem formação aos seus colaboradores. A formação fornecida pelas EAT é dirigida aos técnicos que iniciam funções sem formação, mas também a outros colaboradores, como parte importante da atualização dos conhecimentos e das competências previamente adquiridos, salientando-se que a maioria $(70 \%)$ dos inquiridos recebeu formação (interna e/ou externa) fornecida pelas EAT com as quais colaboram.

À exceção de um dos inquiridos, todos os outros (96.7\%) referiam que a formação que adquiriram era suficiente para o exercício das suas funções. Apesar disso, apenas $76.7 \%$ dos inquiridos menciona que atualmente a formação disponível para os técnicos é suficiente e satisfatória. Os restantes $(23.3 \%)$ referem que não existe formação adequada disponível. Adicionalmente, a maioria (53.3\%) dos inquiridos referiu que não é atribuída suficiente atenção à formação dos técnicos, sendo esta bastante necessária, como já foi referido anteriormente.

Em relação à certificação, 93.3\% concorda que a certificação dos técnicos deveria ser obrigatória. Para além disso, a grande maioria (93.3\%) dos inquiridos indicou também a importância de haver um registo dos técnicos, sendo que para $90 \%$ esse registo deveria ser legislado.

Ainda no que diz respeito a potenciais soluções para o desenvolvimento da profissão, $70 \%$ dos inquiridos considerara relevante a existência de uma associação de profissionais desta área.

No seguimento destas sugestões apresentadas pelos técnicos de desportos de natureza inquiridos, a secção seguinte discute estas problemáticas e apresenta algumas recomendações para a melhoria deste setor.

Tabela 3. Problemáticas do setor dos desportos de natureza e dos técnicos

\begin{tabular}{|c|c|c|}
\hline Indicadores & $n$ & $\%$ \\
\hline \multicolumn{3}{|c|}{ Perceção geral sobre a qualidade dos técnicos } \\
\hline Muito má & 0 & 0.0 \\
\hline Má & 0 & 0.0 \\
\hline Razoável & 10 & 33.3 \\
\hline Boa & 18 & $60 \%$ \\
\hline Muito boa & 2 & $6.7 \%$ \\
\hline \multicolumn{3}{|c|}{ Condições para a melhoria da qualidade dos técnicos } \\
\hline $\begin{array}{l}\text { Obtenção de formação } \\
\text { avançada }\end{array}$ & 21 & 60.0 \\
\hline Outras & 9 & $30 \%$ \\
\hline \multicolumn{3}{|l|}{ Principais problemáticas do setor } \\
\hline Sazonalidade & 7 & 23.3 \\
\hline $\begin{array}{l}\text { Falta de certificação e } \\
\text { legislação }\end{array}$ & 11 & 36.7 \\
\hline Falta de inspeção & 5 & 16.7 \\
\hline Falta de apoios financeiros & 5 & 16.7 \\
\hline Falta de formação & 6 & 20.0 \\
\hline $\begin{array}{l}\text { Falta de divulgação dos } \\
\text { serviços }\end{array}$ & 4 & 13.3 \\
\hline \multicolumn{3}{|c|}{$\begin{array}{l}\text { Principais problemáticas associadas ao exercício da } \\
\text { profissão dos técnicos de deportos de natureza }\end{array}$} \\
\hline Sazonalidade & 18 & 60.0 \\
\hline Baixos rendimentos & 2 & 6.7 \\
\hline $\begin{array}{l}\text { Falta de formação dos } \\
\text { técnicos }\end{array}$ & 4 & 13.3 \\
\hline Limitações de acessibilidade & 1 & 3.3 \\
\hline Nenhuma & 3 & 10.0 \\
\hline \multicolumn{3}{|l|}{ Formação fornecida pela EAT } \\
\hline Sim, formação interna & 17 & 56.7 \\
\hline Sim, formação externa & 4 & 13.3 \\
\hline Não & 9 & 30.0 \\
\hline \multicolumn{3}{|c|}{ Formação suficiente para exercer a profissão } \\
\hline Sim & 29 & 96.7 \\
\hline Não & 1 & 3.3 \\
\hline \multicolumn{3}{|c|}{ Formação suficiente no mercado $(n=30)$} \\
\hline Sim & 23 & 76.7 \\
\hline Não & 7 & 23.3 \\
\hline \multicolumn{3}{|c|}{ Necessidade de certificação obrigatória dos técnicos } \\
\hline Sim & 28 & 93.3 \\
\hline Não & 2 & 6.7 \\
\hline \multicolumn{3}{|l|}{ Necessidade de registo dos técnicos } \\
\hline Sim, legislado & 27 & 90.0 \\
\hline Sim, não legislado & 1 & 3.3 \\
\hline Não & 2 & 6.7 \\
\hline \multicolumn{3}{|c|}{$\begin{array}{l}\text { Criação de uma associação de técnicos de Desportos } \\
\text { de Natureza }\end{array}$} \\
\hline Sim & 21 & 70.0 \\
\hline Não & 9 & 30.0 \\
\hline
\end{tabular}

Discussão e Recomendações

As questões identificadas neste artigo revelaram alguns aspetos problemáticos do estado atual do setor, mais concretamente em relação aos técnicos de desportos de natureza. O papel destes técnicos é muito mais complexo do que os papéis geralmente aceites para um técnico de desporto. O trabalho e o papel dos técnicos dos desportos de natureza é caraterizado pela sua diversidade e complexidade, considerando que operam na fronteira entre o desporto, o turismo e o lazer. É importante notar também que este é um setor emergente e 
relativamente recente, apesar de algumas destas problemáticas já terem vindo a ser discutidas desde a alguns anos, em alguns fóruns de discussão. Todavia, alguns dos problemas identificados neste estudo são de premente resolução. Assim, para tentar resolver algumas das problemáticas identificadas neste estudo, apresentam-se quatro recomendações baseadas na análise e na síntese da informação recolhida, como de seguida se descreve.

\section{Criação de uma associação de técnicos de desportos de natureza}

A criação desta associação de profissionais é essencial para definir e estabelecer um estatuto de carreira dos técnicos de desportos de natureza, para que se possa assegurar a profíssionalização desta atividade. A associação poderá criar códigos de conduta, definir os deveres e os direitos profissionais, inclusive a reivindicação de uma base salarial mais adequada, entre outros regulamentos. Esta associação permitirá também que estes profissionais sejam representados e consultados nos diferentes processos que envolvem o setor, incluindo a sua regulação e regulamentação, formação, certificação e registo de técnicos, entre outros.

Para elevar o reconhecimento, estatuto e oportunidades de carreira, a associação de técnicos, em conjunto com os restantes stakeholders do setor (Instituto Português do Desporto e Juventude e respetiva tutela, Federações Desportivas, Turismo de Portugal e respetiva tutela, APECATE, Instituições de Ensino Superior, entre outros) deverão criar uma task force para examinar a natureza, o papel e as competências mínimas dos técnicos nas diferentes tipologias de OPDN e nos diferentes perfis de enquadramento técnico, com o propósito de enquadrar e regulamentar as competências profissionais em cada um dos perfis.

Para assegurar que os técnicos de desportos de natureza obtenham as qualificações mínimas para o exercício das suas funções deverá ser introduzido um esquema de formação obrigatório para os novos técnicos. A formação deverá ser reconhecida e adequada aos diferentes perfis de enquadramento técnico (formação e educação, lazer e recreação, treino e competição, turismo, etc.).

Para a progressão na carreira deverão ser igualmente desenhados e organizados cursos de formação contínua e de formação avançada, incluindo cursos de gestão de desportos de natureza, o que poderá permitir que os técnicos possam obter uma atualização das suas qualificações e fornecer um percurso de carreira que lhes permita prosseguir do enquadramento técnico a um nível de tarefas de gestão e coordenação de atividades. A formação avançada também será necessária para registos de nível superior na eventualidade de ser adotado um esquema de registo formal dos técnicos.
Para que este processo seja participado, a associação de técnicos dos desportos de natureza, as instituições de ensino superior e os restantes membros do setor, deverão discutir os conteúdos e duração dos cursos de formação inicial, contínua e avançada.

Produção de legislação relacionada com a regulação do acesso à profissão.

Para manter a profíssionalização dos técnicos e a sua estabilidade na profissão a longo termo, deverá ser introduzido um esquema de certificação formal legislado e um registo obrigatório dos técnicos de desportos de natureza, de acordo com os diferentes perfis de enquadramento técnico. A legislação produzida a este respeito poderá eliminar as desigualdades que foram identificadas em relação ao acesso à profissão, em especial através da definição da qualificação mínima a atingir através da formação, tal como o existente no setor do fitness e do exercício físico; Implementação de um sistema de monitorização e avaliação da competência e da performance dos técnicos.

Para assegurar que os técnicos de desportos de natureza são qualificados para o exercício das suas funções, e forneçam serviços de alta qualidade, deverão ser adotadas medidas efetivas para a monitorização e a avaliação da sua performance. Estas poderão incluir, por exemplo, a inspeções nos locais de prática e a introdução de legislação que inclua a penalizações da desadequada qualificação e de más condutas profissionais dos técnicos.

\section{Conclusões/Reflexões finais}

Os técnicos de desportos de natureza apresentam um perfil muito particular. O tipo de trabalho e a sua extensa duração diária por um curto período do ano, muito relacionado com a sazonalidade do trabalho, que origina uma ocupação a tempo parcial e que, na maioria dos casos, não permite um vínculo profissional estável nas OPDN, ligadas ao facto dos técnicos auferirem rendimentos muito baixos no exercício de uma diversidade de funções de extrema responsabilidade - técnicas, logísticas, secretariado, gestão-, leva a maior parte dos técnicos a optarem por ter outras profissões ao longo restante parte do ano. Estas razões, associadas também ao facto dos técnicos, com o avançar da idade, adquirirem outros compromissos familiares (casarem ou viverem com companheiro/a, filhos, etc.), explica o abandono desta carreira por parte de grande parte dos técnicos, quando surge uma outra oportunidade profissional. Daí se pode explicar o perfil sociodemográfico dos técnicos: indivíduos principalmente jovens, solteiros, do sexo masculino, com qualificações académicas elevadas. Adicionalmente, a falta de formação, a falta de regulamentação no acesso à profissão e a falta de monitorização e avaliação da competência e da performance dos técnicos, resulta em muitas situações numa diminuição do know-how adquirido 
pelos técnicos das OPDN e, consequentemente, numa diminuição da oferta de serviços de alta qualidade.

Assim, para que os técnicos de desportos de obtenham benefícios e se encoraje esta como uma atividade profissional séria, estável e duradoura no tempo, deverá ser dado um papel preponderante à associação destes técnicos. Por outro lado, a implementação com sucesso dos programas de formação recomendados e dos sistemas de monitorização e avaliação da competência e da performance dos técnicos requererá a cooperação e a concertação entre a associação de técnicos, os membros relevantes do setor, as autoridades governativas, e os próprios técnicos.

Deverá também ser dada alta prioridade às recomendações que permitam definir a natureza, o papel e as competências mínimas dos técnicos nas diferentes tipologias de OPDN e nos diferentes perfis de enquadramento técnico, o que permitirá assegurar a uniformização e consistência nos standards dos serviços das OPDN que dependem fortemente dos serviços destes técnicos, para que estas organizações prestem serviços de alta qualidade.

Todas estas medidas requerem, todavia, o comprometimento dos principais stakeholders do setor, especialmente a associação de técnicos de desportos de natureza, das OPDN (e.g., EAT, clubes, etc.) e das associações que as representam, e do governo. O comprometimento destes últimos agentes é essencial porque as suas ações influenciam e circunscrevem, em grande medida, o papel e o trabalho dos técnicos de desportos de natureza. Se as recomendações apresentadas forem implementadas a curto ou médio prazo, certamente levará a melhorias consideráveis neste setor em Portugal.

\section{Referências}

Arnould, E. J., \& Price, L. L. (1993). River magic: Extraordinary experiences and the extended service encounter. Journal of Consumer Research, 20(1), 24-45.

Assembleia da República. (2004). Lei n. ${ }^{\circ}$ 30/2004, de 21 de Julho. Diário da República, I Série A, $N^{o}$ $170,4467-4478$

Assembleia da República. (2007). Lei n. ${ }^{\circ}$ 5/2007 de 16 de Janeiro. Diário da República, $1^{a}$ Série, $N^{o}$ $11,356-363$.

Assembleia da República. (2019). Lei no 106/2019, de 06 de setembro. Diário da República, $1{ }^{a}$ Série, $N^{o}$ 171, 51-68. Aubel, O. (2002). Les Enjeux de la Sportivisation de L'escalade Libre. Deux Siècles D'alpinismes Européens. In O. Aubel, O. Hoibian, \& J. Defrance (Eds.), Deux siècles d'alpinismes européens (pp. 273-291). Paris: L'Harmattan.

Barbieri, C., \& Sotomayor. S. (2013). Surf travel behavior and destination preferences: An application of the serious leisure inventory and measure. Tourism Management, 35, 111-121.

Beedie, P. (2003). Mountain guiding and adventure tourism: Reflections on the choreography of the experience. Leisure Studies, 22, 147-167.

Bessy, O., \& Mouton, M. (2004). Du plein air au sport de nature. Nouvelles pratiques, nouveaux enjeux. Revue EP.S, 309, 67-72.

Booth, D. (2018). Nature sports: Ontology, embodied being, politics. Annals of Leisure Research, 23(1), 19-33.

Brymer, E., \& Schweitzer, R. (2017). Evoking the ineffable: The phenomenology of extreme sports. Psychology of Consciousness: Theory, Research, and Practice, 4(1), 63-74.

Cohen, E. (1985). The tourist guide: The origins, structure and dynamics of a role. Annals of Tourism Research, 12, 5-29.

Curtin, S. (2009). Managing the wildlife tourism experience: The importance of tour leaders. International Journal of Tourism Research, 12, 219-236.

Dolnicar, S., \& Fluker, M (2003). Behavioural market segments among surf tourists - Investigating past destination choice. Journal of Sport \& Tourism, 8(3), 186-196.

Gomes, R., Gustavo, N., Melo, R., \& Pedragosa, V. (2017). Portugal: A growing sport market in a dominant state model. In A. Laine \& H. Vehmas (Eds.), Private sport setor in Europe - A crossnational perspective (pp. 269-285). Cham: Springer.

Houge Mackenzie, S., \& Brymer, E. (2020). Conceptualizing adventurous nature sport: a positive psychology perspective. Annals of Leisure Research, 23(1), 79-91.

Jensen, Ø. (2010). Social mediation in remote developing world tourism location - The significance of social ties between local guides and host communities in sustainable tourism development. Journal of Sustainable Tourism, 18, 615-633.

Mathisen, L. (2012). The exploration of the memorable tourist experience. Advances in Hospitality and Leisure, 8, 21-41.

Melo, R. (2013). Desportos de natureza e desenvolvimento local sustentável: Análise dos praticantes e das organizações promotoras dos desportos de natureza. Universidade de Coimbra, Coimbra, Portugal.

Melo, R. (2017). Understanding nature sports participation: A literature review. In R. Melo \& C. Sobry (Eds..), Sport tourism: New challenges in a 
globalized world (pp. 241-275). Newcastle: Cambridge Scholars Publishing.

Melo, R., \& Gomes, R. (2014). Apontamentos históricos e socioculturais dos desportos de natureza. In L. Carvalhinho (Ed.), Desporto de natureza e turismo ativo. Contextos $e$ Desenvolvimento (pp. 35-56). Rio Maior: ESDRM-IPS.

Melo, R., \& Gomes, R. (2016a). Nature sports and sustainable local development: Practitioners and organizations managers' perspectives in Portugal. In C. Sobry (Ed.), Sport tourism and local sustainable development (pp. 75-100). Lille: L'Harmattan.

Melo, R., \& Gomes, R. (2016b). Understanding nature sports organizations in Portugal. The Open Sports Sciences Journal, 9, 13-25.

Melo, R., \& Gomes, R. (2017a). A sociocultural approach to understanding the development of nature sports. In R. Melo \& C. Sobry (Eds.), Sport tourism: New challenges in a globalized world (pp. 60-90). Newcastle: Cambridge Scholars Publishing.

Melo, R., \& Gomes, R. (2017b). Nature sports participation: Understanding demand, practice profile, motivations and constraints. European Journal of Tourism Research, 16, 108-135.

Melo, R., \& Gomes, R. (2017c). Profiling the typologies of nature sports organizations in Portugal. In M. Peris-Ortiz, J. Álvarez-García, \& M. C. del Rio-Rama (Eds.), Sport management as an emerging economy activity (pp. 235-255). Cham: Springer.

Melo, R., \& Leite, D. (2020). The role of nature sports guides to sustainable local development: A case study in the Coimbra region, Portugal. In V. Costa, A. Moura, \& M. R. Mira (Eds.), Human capital and people management in the tourism industry (pp. 371-388). Hershey, PA: IGI Global.

Melo, R., \& Mendes, R. (2011). Gestão do risco e da segurança em desportos de natureza: $\mathrm{O}$ caso dos desportos de montanha. In B. Pereira, A. Silva, \& G. Carvalho (Eds.), Atividade fisica, saúde $e$ lazer. O valor formativo do jogo e da brincadeira (pp. 39-47). Braga: Centro de Investigação em Estudos da Criança, Universidade do Minho.

Melo, R., Van Rheenen, D., \& Gammon, S. (2020a). Part I: Nature sports: A unifying concept. Annals of Leisure Research, 23(1), 1-18.

Melo, R., Van Rheenen, D., \& Gammon, S. (2020b). Part II: Nature sports: Current trends and the path ahead. Annals of Leisure Research, 23(2), 133142.

Ministério do Ambiente do Ordenamento do Território e do Desenvolvimento Regional e da
Economia e da Inovação. (2009). Portaria n. ${ }^{\circ}$ 651/2009, de 12 de Junho. Diário da República, $1^{a}$ Série, $N^{o} 112,3641-3642$.

Ministério das Cidades Ordenamento do Território e Ambiente. (2003). Decreto Regulamentar n. ${ }^{\circ}$ 18/99, Alterado pelo Decreto Regulamentar n. ${ }^{\circ}$ 17/2003, de 10 de Outubro. Diário da República, I Série B, $N^{\circ} 235,6688-6689$.

Ministério da Economia. (2002a). Decreto-Lei n. ${ }^{\circ}$ 47/99, de 16 de fevereiro, alterado pelo DecretoLei n. ${ }^{\circ}$ 56/2002, de 11 de março. Diário da República, I Série A, $N^{\circ}$ 59, 2112-2129.

Ministério da Economia. (2002b). Decreto-Lei n. ${ }^{\circ}$ 204/2000, de 1 de Setembro, alterado pelo Decreto-Lei $n^{\circ}$ 108/2002, de 16 de Abril. Diário da República, I Série A, $N^{o} 89$, 3701-3702.

Ministério da Economia da Inovação e do Desenvolvimento. (2010). Portaria n. ${ }^{\text {o } 1087 / 2010,}$ de 22 de Outubro. Diário da República, $1^{a}$ Série, $N^{\circ} 206,4746-4748$.

Ministério da Economia. (2015). Decreto-Lei n. ${ }^{\circ}$ 186/2015, de 3 de setembro de 2015. Diário da República, $1^{a}$ Série, $N .^{\circ} 172,6947-6982$.

Ministério do Trabalho e da Solidariedade Social. (2007). Decreto-Lei n. ${ }^{\circ}$ 396/2007, de 31 de dezembro. Diário da República, $1^{a}$ Série, $N^{o} 251$, 9165-9173.MSJS. (2015). Sports de Nature: Repères \& Actions. Paris: MSJS.

Orams, M. (1999). Marine tourism: Development, impacts and management. London: Routledge.

The Outdoor Foundation. (2018). 2018 Outdoor recreation participation. Washington, DC: The Outdoor Foundation.

Pereira, E., \& Mykletun, R. (2012) Guides as Contributors to sustainable tourism? A case study from the Amazon. Scandinavian Journal of Hospitality and Tourism, 12(1), 74-94

Pereira, E. (2005). How do tourist guides add value to an ecotour? Interpreting interpretation in the State of Amazonas, Brazil. FIU Review, 23(2), 1-8.

Pimentel, G., \& Melo, R. (2013). Gestão do risco e da segurança em desportos de aventura na natureza: Regulamentação, normalização e certificação. $\mathrm{O}$ caso brasileiro (pp. 239-258). In M. C. Almeida (Ed.), Turismo e desporto na natureza. Estoril: ADA-Desnível/ESHTE.

Pociello, C. (1981). La force, l'énergie, la grâce et les réflexes. Le jeu complexe des dispositions culturelles et sportives. In C. Pociello (Ed.), Sports et société (pp. 171-237). Paris: Editions Vigot.

Pomfret, G. (2011). Package mountaineer tourists holidaying in the French Alps: An evaluation of 
key influences encouraging their participation. Tourism Management, 32, 501-510.

Portugal, A., Campos, F., Martins, F., \& Melo, R. (2017). Understanding the relation between serious surfing, surfing profile, surf travel behaviour and destination attributes preferences. European Journal of Tourism Research, 16, 57-73.

Presidência do Conselho de Ministros. (1996). Resolução do Conselho de Ministros n. ${ }^{\circ}$ 102/96, de 8 de julho. Diário da República, I Série $B, N^{o}$ 156,1762 .

Presidência do Conselho de Ministros. (1999). Decreto-Lei n. ${ }^{\circ} 407 / 99$, de 15 de outubro. Diário da República, I Série A, $N^{o} 241,6944-6950$.

Presidência do Conselho de Ministros. (2008). Decreto-Lei n. ${ }^{\circ}$ 248-A/2008, de 31 de dezembro. Diário da República, $1^{a}$ Série, $N^{o}$ 252, 9300(412)-9300-(415).

Randall, C., \& Rollins, R. (2009) Visitor perceptions of the role of tour guides in natural areas. Journal of Sustainable Tourism, 17(3), 357-374

Rinehart, R., \& Sydnor, S. (2003). To the extreme alternative sports, inside and out. Albany: State University of New York Press.

Rokenes, A., Schumann, S., \& Rose, J. (2015). The art of guiding in nature-based adventure tourism how guides can create client value and positive experiences on mountain bike and backcountry ski tours. Scandinavian Journal of Hospitality and Tourism, 15(sup1), 62-82.

Sports England and Outdoor Industries Association. (2015). Getting active outdoors: a study of demography, motivation, participation and provision in outdoor sport and recreation in England. London: Sports England and Outdoor Industries Association.

Suchet, A. (2011). La sportivisation des pratiques, dites, nouvelles. aspects sociologiques, 18(1), 117.

Turismo de Portugal (2017). Registo Nacional de Turismo: Consulta ao registo. Consultado a $31 \mathrm{de}$ março de $2017 \quad$ em https://registos.turismodeportugal.pt/HomePage. $\underline{\operatorname{aspx}}$

Weiler, B., \& Davis, D. (1993). An exploratory investigation into the roles of the nature-based tour leader. Tourism Management, 14(2), 91-98.

Wheaton, B. (2004). Introduction: Mapping the lifestyle sport-scape. In B. Wheaton (Ed.), Understanding lifestyle sports: Consumption, identity and difference (pp. 1-28). USA and Canada: Routledge.
Wheaton, B. (2013). The cultural politics of lifestyle sports. Routledge.

Wheaton, B. (2016). Lifestyle sport. In B. Houlihan, \& D. Malcolm (Eds.), Sport and society: $A$ student introduction (pp. 109-133). London: Sage.

Wong, J., \& Lee, W. (2012). Leadership through service: An exploratory study of leadership styles of tour leaders. Tourism Management, 33, 11121121.

Yin, R. (1989). Case study research: Design and methods. London: Sage Publications. 


\title{
Avaliação de Espaços de Desporto Natureza: Paisagem Protegida - Serra de Montejunto
}

\author{
Carlos Rebelo $^{1,2}$, Luís Carvalhinho ${ }^{1,2}$
}

${ }^{1}$ Escola Superior de Desporto de Rio Maior - Instituto Politécnico de Santarém (ESDRM-IPS)

${ }^{2}$ Centro de Investigação Desenvolvimento e Inovação em Turismo (CITUR)

\begin{abstract}
Palavras-chave Desporto de

Natureza e Turismo

Ativo;

Locais de Prática;

Áreas Protegidas;

Escalada;

Pedestrianismo.

\section{RESUMO:}

A Paisagem Protegida da Serra de Montejunto, sendo uma Área Protegida (AP) com potencial para a prática de desportos de natureza e turismo ativo, carece ainda de um instrumento de gestão e informação útil para os diversos visitantes, à semelhança das "Cartas de Desporto de Natureza" existentes em outras AP do país. Assim, o presente estudo pretendeu caracterizar e avaliar os locais de prática de atividades de desporto de natureza e turismo ativo, nomeadamente, locais de prática de Escalada e de Pedestrianismo, recorrendo à utilização de fichas de caracterização e avaliação sobre todos os locais previamente identificados. Os resultados obtidos permitiram aferir o potencial desta AP para a prática de atividades de desporto de natureza e demonstraram a conformidade dos locais de prática, detetando apenas a existência de algumas situações pontuais de inadequação de equipamentos, falta de conservação dos mesmos e do meio envolvente. Concluiu-se que a prática de atividades de desporto de natureza apresenta um grande potencial nesta AP, verificando-se, contudo, a necessidade da realização de trabalho de planeamento, gestão e manutenção dos espaços, no sentido de garantir a conservação e a sustentabilidade dos mesmos.
\end{abstract}

\section{Keywords}

Nature Based-Sports and Active Tourism; Practice Places; Protected Area; Climbing; Hiking.
Evaluation of spaces of nature-based sports of landscape - Serra de Montejunto

\section{ABSTRACT:}

The protected Area of Serra de Montejunto, as a Protected Area (AP) with potential for naturebased sports and active tourism activities, needs a useful management tool for different types of visitors, similar to the "Nature Sport Charts" existing in other APs in the country.

Thus, this research aimed to characterize and evaluate the places for practice of nature-based sports and active tourism activities, namely places of climbing and hiking, using the characterization and evaluation sheets on all previously identified places.

The results of this investigation aim to affirm the potential of this AP for sports activities practice in nature and demonstrated the good conditions that exists in practice sites, detecting only the presence of some occasional situations of inadequacy, lack or conservation of equipment.

It is concluded that the practice of nature-based sport activities has a great potential in this AP, verifying however the necessity of carrying out strategies that involve: planning, management and maintenance of spaces in order to guarantee conservation and sustainability of the area. 


\section{Avaliação de espaços de desporto de natureza: Paisagem Protegida - Serra de Montejunto}

As Áreas Protegidas constituem-se como zonas do território preferenciais para a opção de destinos turísticos, não apenas por parte de praticantes de atividades de desporto de natureza, mas também por outro tipo de turistas mais ativos que procuram novas sensações e experiências em locais onde possam estar em contato e harmonia com a natureza e a biodiversidade. Sendo estes os principais pontos de atração, surge a necessidade de conhecer as potencialidades dos locais e, ao mesmo tempo, estabelecer uma harmonia entre a proteção dos valores existentes e o contato dos praticantes com esses mesmos valores.

Segundo Rosalino e Grilo (2011), a gestão de uma área protegida depende de um agrupamento de informação que está disponível, e quantos mais dados estiverem ao dispor, maior é a probabilidade de esta gestão ser melhor e mais persuasiva. A definição, caracterização e avaliação dos espaços de prática permite um controlo das atividades e uma monitorização muito mais eficazes.

O presente estudo incide sobre os locais de prática de atividades de desporto de natureza na Paisagem Protegida da Serra de Montejunto (PPSM). O principal objetivo prende-se com a realização de uma caracterização e avaliação detalhadas dos locais de prática de atividades de desporto de natureza no âmbito das modalidades de Escalada e Pedestrianismo, tomando em consideração diversos aspetos de localização, espaço envolvente, segurança, conservação do meio, adequação e certificação dos equipamentos, através de análise visual e experimental.

É evidente a íntima relação entre o desporto e a natureza, apresentando-se esta como cenário para a realização de diversas modalidades, suscitando uma constante interação entre o praticante e o ambiente natural (Paixão, Costa \& Gabriel, 2009).

No entanto, sendo o espaço natural o agente potenciador do desenvolvimento deste tipo de práticas poderá surgir a ameaça à integridade ecológica. A erosão e compactação no solo de vários nutrientes e microrganismos, devido à formação de trilhos, exposição de raízes e lixo deixado pelos praticantes e também por quem os acompanha (Buckley, 2004; Turton, 2005; Mende \& Newsome, 2006; Randall \& Newsome, 2008; Pickering, Hill, Newsome \& Leung, 2010); o aumento da turgidez da água, associado à erosão e suspensão de sedimentos sobre a mesma (Hadwen, Arthington, Boon, Lepesteur \& McComb, 2006; Hadwen, Arthington \& Boonington, 2008; Hardiman \& Burgin, 2011); e também a ocorrência de alterações faunísticas, alterando os padrões de alimentação dos animais, menor reprodução e diversidade de espécies (Buckley, 2004; Newsome, Dowling \& Moore, 2005; Stevens, Pickering \& Castley, 2011), constituem alguns dos impactes negativos que se podem verificar.

Rosa e Carvalhinho (2012) defendem que a interação entre o Homem e a Natureza existe, mas que a prática de atividades desportivas não leva a que os praticantes tenham a perceção imediata do respeito que precisam de ter pelo meio natural. Sendo ultrapassada a capacidade de carga de um espaço, o risco de alterações irreversíveis no ecossistema aumenta, colocando em causa a subsistência das espécies que aí habitam (Alves, Rodrigues \& Carvalhinho, 2013). Segundo Costa (2006), os principais aspetos a considerar aquando da escolha dos locais de prática incluem: as acessibilidades e os meios de transporte disponíveis; a beleza paisagística e a segurança (incluindo facilidade de resgate em caso de emergência), tanto para os praticantes como para possíveis espetadores. Neste contexto, outros fatores motivadores determinantes da escolha são também o estado de conservação e limpeza dos locais de prática, assim como a possível geração de impactes ambientais. Para a prática das diversas modalidades, Costa (2006) apresenta os três fatores determinantes para a escolha de um local para a prática de escalada, rapel e trekking, sendo eles; i) o nível de conservação ambiental; ii) a segurança (especialmente destacada a proximidade da comunidade local por razões de socorro urgente); iii) e a autorização prévia para a utilização do espaço de prática.

\section{Metodologia}

A caracterização e a avaliação dos espaços da PPSM identificados com potencial para a prática de atividades de desporto de natureza e turismo ativo foi efetuada através de um cruzamento de dados recolhidos por uma Análise Documental (com recurso à pesquisa de informação disponível contida em mapas e folhetos cedidos pelos Municípios e também em blogs e fóruns de praticantes de pedestrianismo e de escalada), pela observação e recolha de dados no terreno e por reuniões de trabalho com os Municípios do Cadaval e de Alenquer (Membros da Comissão de Gestão da PPSM). Este estudo pretende ser também um contributo para a deteção de situações irregulares que possam colocar em causa a segurança dos praticantes, e para a constituição de um registo de informação útil sobre os locais de prática.

Os instrumentos utilizados para recolher os dados no terreno foram previamente validados e utilizados noutros estudos por diferentes autores (Brandão, 2011; Carvalhinho \& Rosa, 2012; Pereira, Canhoto, Mateus, Rosa \& Carvalhinho, 2012; Rosa, Raimundo, Sanz, Silveira \& Carvalhinho, 2012; Carvalhinho \& Rosa, 2013).

Segundo estes autores, o processo de construção e validação obedeceu aos seguintes passos: i) Elaboração da primeira versão segundo o conhecimento teórico-prático e revisão bibliográfica 
acerca do tema; ii) Revisão efetuada por três especialistas, os quais sugeriram modificação de algumas questões estruturais e de compreensão das fichas; iii) Elaboração da segunda versão, tendo em consideração as recomendações efetuadas; iv) Primeira aplicação piloto das fichas no terreno, efetuada por observadores $(\mathrm{n}=3)$; v) Segunda aplicação piloto das fichas no terreno, após duas semanas, efetuada pelos mesmos observadores; vi) Verificação da fidelidade intra e inter observadores; vii) Produção da versão final das fichas.

Para efetuar a análise dos percursos pedestres foi utilizada, para cada percurso, uma ficha de caracterização e uma ficha de avaliação. A primeira constituiu-se como um instrumento que teve como intuito a caracterização dos percursos pedestres em três áreas fundamentais: a Ficha Técnica do Percurso, a qual pressupôs a recolha de informações de localização e do trilho (tipo de solo, desnível, extensão, duração, localização, tipo de percurso, pontos de referência, pontos de água potável, sinalética, condicionantes, entidade responsável pela abertura do trilho, entidade gestora, população-alvo, capacidade máxima e altimetria); a segunda área prendeu-se com a Caracterização do Espaço Envolvente (principais acessos rodoviários, extensão da área envolvente, acesso ao trilho, tipo de vegetação envolvente, fauna dominante, relevo, infraestruturas de apoio, outras atividades possíveis de praticar e elementos culturais/naturais de interesse); a terceira área foi referente às características de Segurança (sinalização, acessibilidade a centros e/ou equipas de socorro, condições climatéricas, controlo técnico e pedagógico do espaço e meios de comunicação). A Ficha teve por objetivo permitir a avaliação dos percursos, no que concerne à existência de problemas, conduzindo à sua resolução. A avaliação foi realizada pela atribuição de três níveis de apreciação associados a cada uma das variáveis consideradas e através do registo em "Km", em termos de distância percorrida no percurso, onde o problema se verificou. As grandes áreas de avaliação foram respeitantes ao Trajeto (percurso facilmente identificável, obstáculos a impedir o caminho, visibilidade do percurso e cruzamento de percursos), Marcação e Sinalética (desgaste na coloração da sinalética, sinalética danificada, necessidade de sinalética, sinalética incorreta, outras), Conservação do Meio (existe lixo ao longo do percurso, existem danos evidentes em árvores ou outro tipo de vegetação adjacente ao trilho, problemas de drenagem, depósitos para lixo, existência de trilhos secundários, outros), e a Segurança do percurso (perigo de queda de pedras, perigo de queda de árvores, exposição à queda, animais selvagens, obras de proteção, indicação de zonas perigosas, outros).

Relativamente aos locais de prática de Escalada, aplicou-se uma ficha de caracterização e uma ficha de avaliação específicas para cada um dos setores. Nesta fase pretendeu-se caracterizar os setores/vias de
Escalada existentes, mediante três parâmetros: Caracterização do Espaço Envolvente (localização, principais acessos rodoviários, acessibilidade à parede, extensão da área envolvente), Caracterização Específica do Espaço de Escalada (altitude, coordenadas, vertentes de prática, condicionantes, entidade gestora, paredes de escalada), e Características de Segurança (sinalização, capacidade de carga do espaço envolvente, acessibilidade a centros e/ou equipas de socorro, condições climatéricas, controlo técnico e pedagógico do espaço, meios de comunicação).

Quanto à ficha de avaliação dos setores de Escalada, esta foi dividida em duas componentes: i) Avaliação do setor e espaço envolvente - realizada através da atribuição de três níveis de apreciação associados a cada uma das variáveis consideradas, do valor (em metros), em termos de distância percorrida, no caso da primeira dimensão em análise (trilho de acesso), onde o problema se verificou, e do número da via mais próxima/onde o problema se verificou. As dimensões englobadas nesta componente referiramse ao Acesso ao Setor de Escalada (percurso facilmente identificável, obstáculos a impedir o caminho, visibilidade do percurso e cruzamento de percursos), Marcação e Sinalética (desgaste na coloração da sinalética, sinalética danificada, necessidade de sinalética, outras), Conservação do Meio (existe lixo nas zonas de escalada, existem danos evidentes em árvores ou outro tipo de vegetação nas zonas de escalada existem danos evidentes na vegetação das vias de escalada, depósitos para lixo, existência de rochas claramente danificadas, outros), e a Segurança dos setores (perigo de queda de pedras, exposição à queda, animais selvagens, indicação de zonas perigosas, outros); ii) Avaliação dos Equipamentos Fixos das Vias - Certificação (sim ou não) dos equipamentos, Adequação dos equipamentos utilizados, Conservação e estado dos equipamentos (esta avaliação foi efetuada de duas formas distintas, visual e experimental).

A recolha dos dados foi efetuada através de levantamentos in situ pelo investigador e do preenchimento das fichas de caracterização e de avaliação para cada local, com indicadores relevantes, e da consulta às entidades responsáveis pela gestão da PPSM.

No entanto, importa sublinhar a pertinência do alargamento do estudo efetuado a outras modalidades e outros locais de prática. Admitimos que a avaliação de locais de prática relacionada com apenas duas modalidades constitui uma visão um pouco redutora da globalidade da paisagem protegida, mas a informação que possuíamos em relação aos locais de prática das restantes modalidades era insuficiente e pouco credível que nos permitisse caracterizar e analisar os mesmos.

Resultados 
Os resultados da caracterização e avaliação dos locais de prática de desporto de natureza identificados foram obtidos individualmente, tomando em consideração os dados recolhidos de acordo com a metodologia anteriormente descrita.

Foram analisados quatro percursos pedestres, marcados na sua totalidade: o percurso da "Quinta da Serra", o percurso da "Biodiversidade", o percurso dos "Currais e Calçada" e o percurso dos "SS", ainda que não homologados segundo as normas da Federação de Campismo e Montanhismo de Portugal (FCMP). A pesquisa documental e os contatos efetuados com os Municípios indicaram-nos, inicialmente, a existência de onze percursos pedestres. No entanto, após verificação no terreno constatámos que apenas os percursos acima referidos estavam sinalizados, o que nos levou a optar apenas pela análise dos percursos anteriormente referidos. Foram igualmente analisados dois locais de Escalada, denominados de "Montejunto Velho - Penha do Meio Dia" e "Montejunto Novo - Penha / Escarpa do Relvio", contendo o primeiro, seis setores e o segundo dois setores de prática desta modalidade.

\section{Escalada}

Um dos locais identificados para a prática de Escalada foi o local de "Montejunto Velho - Penha do Meio Dia". A acessibilidade a estes setores é efetuada por trilhos com um tipo de solo pedregoso e rochoso e um desnível médio.

A distância a percorrer desde a estrada mais próxima até ao local são cerca de cento e cinquenta metros, demorando em média 10 minutos. Este tempo de percurso deve-se à dificuldade do acesso e à inclinação do terreno. É um local que está disponível para a prática de Escalada entre os meses de agosto e dezembro, estando nos restantes meses, condicionada a sua prática devido à nidificação de aves neste local. O tipo de vegetação que circunda este local e o acesso ao mesmo é herbácea (até 20 centímetros de altura) e arbustiva (até cinco metros de altura). O relevo é montanhoso. A fauna aqui dominante é o corvo, o peneireiro e o andorinhão, sendo espécies que nidificam neste local.

Neste espaço não se encontram quaisquer infraestruturas de apoio à prática. Existem, contudo, instalações junto ao Centro de Interpretação Ambiental, a cerca de $1.5 \mathrm{~km}$.

A altitude mínima possível de escalar é de 398 metros, onde fica situado o setor de Escalada "Isapaulo". A altitude máxima é de 480 metros, que corresponde ao setor "Cogumelo Mágico". A vertente de prática de Escalada nos setores situados no Montejunto Velho - Penha do Meio Dia é a Escalada Desportiva, sendo esta uma das variantes da modalidade de Escalada.

A entidade responsável pela gestão é composta por três representantes do setor público (Instituto da Conservação da Natureza e das Florestas - ICNF, Município do Cadaval e Município de Alenquer). No entanto, esta não possui uma avaliação formal (Croqui) dos setores de prática de Escalada nem mesmo, livros ou panfletos alusivos aos mesmos.

A rocha aqui presente é do tipo calcário, na qual foram instalados alguns equipamentos homologados para a prática de Escalada, tais como plaquetes, Tijes e Topos. Neste espaço podemos encontrar vias com inclinação positiva, vertical ou negativa, variando o seu grau de dificuldade (de acordo com a escala francesa) entre o $4+$ e o $7 b+$, conforme podemos verificar na seguinte tabela.

Tabela 1. Número de vias de Montejunto-Velho por setor e grau de dificuldade

\begin{tabular}{|c|c|c|c|c|c|c|c|c|c|c|c|c|c|c|}
\hline & \multirow[b]{2}{*}{$\begin{array}{l}\text { Setor } \\
\text { Isanaulo }\end{array}$} & \multicolumn{13}{|c|}{$\mathrm{N}^{0}$ de vias por grau de dificuldade } \\
\hline \multirow{6}{*}{$\begin{array}{c}\text { Montejunto } \\
\text { Velho }\end{array}$} & & $4+$ & $5 \mathrm{a}$ & $5 c$ & $6 a$ & $6 \mathrm{a}+$ & $\begin{array}{c}6 b \\
1\end{array}$ & $\begin{array}{c}6 \mathrm{~b}+ \\
1\end{array}$ & $\begin{array}{c}6 c \\
1\end{array}$ & $6 \mathrm{c}+$ & $7 \mathrm{a}$ & $7 \mathrm{a}+$ & $7 \mathrm{~b}$ & $7 \mathrm{~b}+$ \\
\hline & Eucaliptus & 1 & 1 & & 1 & & 1 & 1 & & & & & & \\
\hline & $\begin{array}{l}\text { Música no } \\
\text { Coração }\end{array}$ & & & 3 & 1 & 1 & & 1 & & & & & & \\
\hline & Natanifo & & & & 1 & 3 & 1 & 1 & 3 & & 2 & 3 & 2 & 1 \\
\hline & $\begin{array}{l}\text { Impressões } \\
\text { Digitais }\end{array}$ & & & & & & & & & 1 & & & & \\
\hline & $\begin{array}{l}\text { Cogumelo } \\
\text { Mágico }\end{array}$ & & & & & & 1 & & & & & & & \\
\hline
\end{tabular}

Existe uma grande variedade de vias com graus de dificuldade diferente, o que permite a prática a pessoas com distintos níveis de experiência. No entanto, conforme podemos constatar na tabela 2 estes setores são mais propícios à prática de Escalada por parte de jovens e adultos já com algum conhecimento e que pretendam desenvolver e aperfeiçoar o seu nível técnico de prática desta modalidade. Este não é um local de prática adequado para crianças ou populações especiais, pois o acesso à parede é de uma dificuldade elevada e o grau de complexidade de execução das vias não permite a prática ao nível da iniciação. 
Tabela 2. Localização e principais características técnicas de cada setor

\begin{tabular}{|c|c|c|c|c|c|}
\hline \multicolumn{2}{|c|}{ Setor } & \multirow{2}{*}{$\begin{array}{c}\text { Coordenadas } \\
9^{\circ} 03.449^{\prime} \mathrm{W} \\
39^{\circ} 11.551^{\prime} \mathrm{N}\end{array}$} & \multirow{2}{*}{$\begin{array}{c}\mathbf{N}^{0} \text { de tops } \\
3\end{array}$} & \multirow{2}{*}{$\begin{array}{c}\text { Nível de } \\
\text { dificuldade/prática }\end{array}$} & \multirow{2}{*}{$\begin{array}{l}\text { População-alvo } \\
\text { Jovens; Adultos }\end{array}$} \\
\hline & Isapaulo & & & & \\
\hline & Eucaliptus & $\begin{array}{l}9^{\circ} 03.436^{\prime} \mathrm{W} \\
39^{\circ} 11.539^{\prime} \mathrm{N}\end{array}$ & 2 & $\begin{array}{c}\text { Iniciação / } \\
\text { Aprendizagem; } \\
\text { desenvolvimento/ } \\
\text { Aperfeiçoamento }\end{array}$ & Jovens; Adultos \\
\hline \multirow[t]{4}{*}{$\begin{array}{l}\text { Montejunto } \\
\text { Velho }\end{array}$} & $\begin{array}{l}\text { Música no } \\
\text { Coração }\end{array}$ & $\begin{array}{l}9^{\circ} 03.436^{\prime} \mathrm{W} \\
39^{\circ} 11.539^{\prime} \mathrm{N}\end{array}$ & 4 & $\begin{array}{c}\text { Iniciação / } \\
\text { Aprendizagem; } \\
\text { desenvolvimento/ } \\
\text { Aperfeiçoamento }\end{array}$ & Jovens; Adultos \\
\hline & Natanifo & $\begin{array}{l}9^{\circ} 03.456^{\prime} \mathrm{W} \\
39^{\circ} 11.513^{\prime} \mathrm{N}\end{array}$ & 9 & $\begin{array}{c}\text { Desenvolvimento/ } \\
\text { Aperfeiçoamento; } \\
\text { Avançado }\end{array}$ & Jovens; Adultos \\
\hline & $\begin{array}{c}\text { Impressões } \\
\text { Digitais }\end{array}$ & $\begin{array}{l}9^{\circ} 03.448^{\prime} \mathrm{W} \\
39^{\circ} 11.489^{\prime} \mathrm{N}\end{array}$ & 1 & $\begin{array}{l}\text { Desenvolvimento/ } \\
\text { Aperfeiçoamento }\end{array}$ & Jovens; Adultos \\
\hline & $\begin{array}{l}\text { Cogumelo } \\
\text { Mágico }\end{array}$ & $\begin{array}{l}9^{\circ} 03.433^{\prime} \mathrm{W} \\
39^{\circ} 11.472^{\prime} \mathrm{N}\end{array}$ & 1 & $\begin{array}{l}\text { Desenvolvimento/ } \\
\text { Aperfeiçoamento }\end{array}$ & Jovens; Adultos \\
\hline
\end{tabular}

No que respeita ainda à caracterização destes setores, verificamos que os mesmos não possuem qualquer limitação correspondente à capacidade máxima de praticantes. Este facto deveria ser informado e monitorizado, por quem de direito, o qual nos parece de extrema importância para a sustentabilidade desta área.

Não existe, também, qualquer informação acerca da entidade responsável que efetuou a equipagem das vias, nem da data da última equipagem, o que pode conferir alguma incerteza no que respeita à certificação e conservação dos materiais utilizados.

A avaliação dos setores do Montejunto Velho - Penha do Meio Dia e do espaço envolvente possibilitou-nos detetar alguns problemas, nomeadamente a já referida dificuldade de acessibilidade à parede, identificandose a presença de rochas e árvores no acesso à parede. Relativamente à marcação e sinalética, denotamos uma séria degradação e danificação da única sinalética existente no local. A par disto, existem também alguns locais que requerem a necessidade de sinalização, tais como na indicação do acesso à parede ou croqui informativo das vias.

Quanto à conservação do meio não verificámos a existência de qualquer problema, nomeadamente lixo nas zonas de escalada ou danos evidentes em rochas, árvores ou outro tipo de vegetação nas zonas e vias utilizadas para a prática. Do mesmo modo, não identificámos problemas no que respeita à segurança dos setores, tais como o perigo de queda de pedras, animais selvagens ou exposição involuntária à queda, não sendo, contudo, necessária indicação de zonas perigosas através de sinalética.

Os equipamentos fixos das vias foram também avaliados: a certificação/homologação dos equipamentos, a sua adequação à função específica que desempenha e o estado de conservação dos equipamentos.

Verificámos, nesta área, que existem trinta e três vias equipadas, sendo que a grande maioria das vias estão equipadas com Plaquetes e pernos, havendo apenas algumas equipadas com Tiges. Estes são materiais devidamente certificados e adequados à sua função específica para o fim a que se destinam. Encontramse em bom estado de conservação e, por isso, passíveis de serem utilizados para a prática de escalada. Os Topos instalados encontram-se também em boas condições de conservação, são adequados e estão certificados, levando-nos a crer que estas vias terão sido (re)equipadas recentemente.

Outro local identificado para a prática de Escalada foi o "Montejunto Novo - Penha/Escarpa do Relvio". Neste local podemos identificar dois setores de Escalada: "Anões" e "Dementes". A acessibilidade a estes dois setores efetua-se percorrendo uma distância de cerca de 50 metros, durante cinco minutos, com um desnível médio, através de trilhos com um tipo de solo pedregoso e rochoso. Estes trilhos encontram-se bem definidos, por força do pisoteio da vegetação por parte dos praticantes que regularmente ali passam. $\mathrm{O}$ tipo de vegetação que se encontra neste local e respetivo acesso ao mesmo é herbácea (até 20 centímetros de altura) e também arbustiva (até cinco metros de altura), mas em menor quantidade. $\mathrm{O}$ relevo é montanhoso.

Este setor não é uma área de nidificação de aves, sendo assim, possível praticar Escalada durante o ano inteiro.

Junto a esta zona também não se encontram quaisquer infraestruturas de apoio à prática. O Centro de Interpretação Ambiental, que fica situado a cerca de 
$1 \mathrm{Km}$ (para Norte). No que respeita à caracterização específica do espaço de Escalada verificamos que é um local que se destina à prática de Escalada Desportiva, sem condicionantes de prática. Os setores situam-se a uma altitude de 514 metros. Verificámos também que não existe um Croqui, livro ou panfleto alusivos a estes setores de Escalada.
A parede é constituída por rocha calcária, na qual foram colocados equipamentos homologados para a prática de Escalada. No setor "Anões" encontrou-se os Topos e Tijes colocados na rocha, enquanto no setor "Dementes", as vias estão equipadas com Plaquetes e Topos. Nestes dois setores podemos encontrar vias com inclinação vertical e negativa.

Tabela 3. Número de vias de cada setor e respetivo grau de dificuldade

\begin{tabular}{|c|c|c|c|c|c|c|c|c|c|c|c|c|c|c|c|c|}
\hline & & \multicolumn{15}{|c|}{$\mathrm{N}^{\circ}$ de vias por grau de dificuldade } \\
\hline \multicolumn{2}{|l|}{ Setor } & $3+$ & 4 & $4+$ & $5^{\mathrm{a}}$ & $6 a$ & $6 a+$ & $6 \mathrm{~b}$ & $6 \mathrm{~b}+$ & $6 c$ & $7 \mathrm{a}$ & $7 \mathrm{~b}$ & $7 \mathrm{~b}+$ & $7 \mathrm{c}$ & $7 \mathrm{c}+$ & $8 \mathrm{a}$ \\
\hline \multirow{2}{*}{ Montejunto Novo } & Anões & & & & & & & 1 & 1 & & 1 & 1 & 1 & 2 & 1 & \\
\hline & Dementes & 1 & 1 & 1 & 1 & 1 & 3 & 2 & 1 & 3 & 1 & 4 & 3 & 1 & & 1 \\
\hline
\end{tabular}

Existe uma grande variedade de vias com graus de dificuldade diferente, sendo que consideramos que o setor "Anões", pelo grau de dificuldade, se destina à prática de Escalada por parte de jovens e adultos com algum conhecimento e experiência sobre esta modalidade e que pretendam desenvolver e aperfeiçoar o seu nível técnico. O setor "Dementes" é muito mais diversificado, podendo englobar diferentes tipos de praticantes em diversos níveis. Devido ao mau acesso até à parede, este não é um local adequado para receber populações especiais.

Tabela 4. Localização e principais características técnicas de cada setor

\begin{tabular}{|c|c|c|c|c|c|}
\hline \multicolumn{2}{|c|}{ Setor } & Coordenadas & $\mathrm{N}^{\mathrm{o}}$ de tops & Nível de & População-alvo \\
\hline \multirow{2}{*}{$\begin{array}{c}\text { Montejunto } \\
\text { Novo }\end{array}$} & Anões & $\begin{array}{l}9^{\circ} 04.346^{\prime} \mathrm{W} \\
39^{\circ} 10.612^{\prime} \mathrm{N}\end{array}$ & 6 & $\begin{array}{c}\text { Desenvolvimento/ } \\
\text { Aperfeiçoamento; } \\
\text { Avançado }\end{array}$ & $\begin{array}{l}\text { Jovens; } \\
\text { Adultos }\end{array}$ \\
\hline & Dementes & $\begin{array}{l}9^{\circ} 04.346^{\prime} \mathrm{W} \\
39^{\circ} 10.612^{\prime} \mathrm{N}\end{array}$ & 19 & $\begin{array}{c}\text { Iniciação / } \\
\text { Aprendizagem; } \\
\text { desenvolvimento/ } \\
\text { Aperfeiçoamento; } \\
\text { Avançado }\end{array}$ & $\begin{array}{l}\text { Crianças; } \\
\text { Jovens; } \\
\text { Adultos }\end{array}$ \\
\hline
\end{tabular}

Verificou-se também que o "Montejunto Novo Escarpa/Penha do Relvio" não possui qualquer limitação correspondente à capacidade máxima de praticantes. Não existem informações acerca da data da equipagem das vias nem sobre a responsabilidade da mesma.

Efetuando uma avaliação dos espaços de escalada no que concerne à existência de problemas e à dificuldade para a sua resolução constatou-se que os acessos aos Topos das vias não estão devidamente equipados nem possuem possibilidades de serem realizadas proteções expeditas. Detetámos ainda a falta de sinalização referente a zonas de perigo.

No que respeita à avaliação dos equipamentos fixos das vias constatou-se que, no setor "Anões" as vias estão equipadas com Tiges. Estes equipamentos não são certificados, no entanto, são adequados e encontram-se em bom estado de conservação. Dos seis Topos instalados neste setor, todos são certificados e adequados à função específica a que se destinam, mas dois encontram-se em mau estado de conservação, não se encontrando nas condições necessárias que permitam a sua utilização. Por outro Tabela 5. Características dos Percursos Pedestres lado, no setor "Dementes" as vias de escalada estão equipadas com Plaquetes e Pernos devidamente certificados e em bom estado de conservação. Encontrámos, no entanto, além de serem certificados, três Topos em mau estado de conservação, havendo a necessidade imediata de os substituir. Os restantes apresentam boas condições de conservação, podendo ser utlizados.

De uma forma geral, dentro dos parâmetros analisados, o espaço do "Montejunto Novo -Penha/ Escarpa do Relvio" apresenta boas condições para a prática de Escalada.

\section{Percursos Pedestres}

A tabela 5, refere-se aos Percursos Pedestres estudados e permite efetuar uma análise global e específica de cada percurso, através das diferentes variáveis. 


\begin{tabular}{|c|c|c|c|c|}
\hline $\begin{array}{c}\text { Informação sobre } \\
\text { o percurso }\end{array}$ & PP1 & PP2 & PP3 & PP4 \\
\hline Nome & $\begin{array}{c}\text { Trilho Quinta da } \\
\text { Serra }\end{array}$ & $\begin{array}{c}\text { Trilho da } \\
\text { Biodiversidade }\end{array}$ & $\begin{array}{c}\text { Trilho Currais e } \\
\text { Calçada }\end{array}$ & Trilho dos SS \\
\hline Extensão & $4,8 \mathrm{~km}$ & $1,8 \mathrm{~km}$ & $6 \mathrm{~km}$ & $8 \mathrm{~km}$ \\
\hline Duração média & $1 \mathrm{~h} 30$ & -- & $2 \mathrm{~h} 00$ & $2 \mathrm{~h} 30$ a $3 \mathrm{~h} 00$ \\
\hline Tipo & Circular & Circular & Circular & Circular \\
\hline Tipo de solo & $\begin{array}{c}\text { Argiloso } \\
\text { Pedregoso }\end{array}$ & $\begin{array}{c}\text { Argiloso } \\
\text { Pedregoso }\end{array}$ & $\begin{array}{c}\text { Pedregoso } \\
\text { Rochoso }\end{array}$ & Pedregoso \\
\hline $\begin{array}{l}\text { Sinalética: } \\
\text { Correta } \\
\text { Estado de conservação } \\
\text { Homologada }\end{array}$ & $\begin{array}{l}\text { Sim } \\
\text { Bom } \\
\text { Não }\end{array}$ & $\begin{array}{l}\text { Específica } \\
\text { Sim } \\
\text { Bom } \\
\text { Não }\end{array}$ & $\begin{array}{c}\text { Em excesso } \\
\text { Bom } \\
\text { Não }\end{array}$ & $\begin{array}{l}\text { Sim } \\
\text { Bom } \\
\text { Não }\end{array}$ \\
\hline $\begin{array}{l}\text { Sinalização de aviso } \\
\text { de perigos }\end{array}$ & Sim, 2 & Não & Não & Não \\
\hline Painel com mapa/croqui & Não & Sim & Não & Não \\
\hline Época do ano & Todo o ano & Todo o ano & Todo o ano & Todo o ano \\
\hline Capacidade de carga & Não definida & Não definida & Não definida & Não definida \\
\hline $\begin{array}{l}\text { Condições do trajeto } \\
\text { (obstáculos) }\end{array}$ & Boa & Boa & $\begin{array}{c}\text { Razoável } \\
\text { (vegetação } \\
\text { intensa) }\end{array}$ & $\begin{array}{c}\text { Razoável (pedras } \\
\text { soltas) }\end{array}$ \\
\hline Interceções & PP2 & $\begin{array}{l}\text { PP1 } \\
\text { PP3 }\end{array}$ & Não tem & Não tem \\
\hline Vegetação & $\begin{array}{c}\text { Herbácea } \\
\text { (predominante) } \\
\text { Arbustiva } \\
\text { Arbórea } \\
\end{array}$ & $\begin{array}{c}\text { Demonstrada ao } \\
\text { longo do percurso } \\
\text { com painéis } \\
\text { informativos } \\
\end{array}$ & $\begin{array}{c}\text { Arbustivo } \\
\text { (predominante) } \\
\text { Vários tipos }\end{array}$ & $\begin{array}{c}\text { Herbácea } \\
\text { (predominante) } \\
\text { Arbustiva } \\
\text { Arbórea } \\
\end{array}$ \\
\hline Pontos de interesse & $\begin{array}{c}\text { Centro Interpretação } \\
\text { Ambiental } \\
\text { Posto de vigia }\end{array}$ & $\begin{array}{l}\text { Biodiversidade } \\
\text { (painéis } \\
\text { informativos) }\end{array}$ & $\begin{array}{c}\text { Calçada dos } \\
\text { Frades } \\
\text { Covão das Pias }\end{array}$ & $\begin{array}{c}\text { Vale da } \\
\text { Cascalheira } \\
\text { Vale da Ramada } \\
\text { Igreja N. Sr. }^{\text {a }} \\
\text { Neves } \\
\text { Capela de S. João } \\
\text { Ruínas do } \\
\text { Convento } \\
\text { Dominicano }\end{array}$ \\
\hline
\end{tabular}

Os percursos pedestres analisados possuem algumas características que são comuns entre si. Todos eles são do tipo circular e possuem pontos de partida e de chegada comuns, i.e., junto ao Centro de Interpretação Ambiental da Serra de Montejunto, tomando depois, trajetos diferentes. As infraestruturas de apoio são também comuns a todos os percursos. Junto ao ponto de partida e de chegada, os praticantes poderão usufruir dos balneários pertencentes ao Parque de Campismo, com chuveiros e instalações sanitárias. Existe também um café e estacionamento para cerca de trinta automóveis ligeiros e seis autocarros. Além das características comuns, cada trilho possui as suas próprias especificidades.

\section{a) Trilho Quinta da Serra:}

Tem uma extensão de $4.8 \mathrm{Km}$ e uma duração média de $1.30 \mathrm{~h}$ para ser realizado. Este é efetuado por caminhos de terra e trilhos com um tipo de solo argiloso e pedregoso. Como pontos de interesse ao longo deste percurso identifica-se, desde logo, o Centro de Interpretação Ambiental, local de início e final do percurso e a passagem pelo Posto de Vigia pouco depois do quilómetro três. O percurso pode ser realizado durante o ano inteiro. No que respeita à sinalética, confirmou-se que o percurso se encontra sinalizado na sua totalidade, no entanto, este não é homologado pela FCMP. Podemos encontrar vários tipos de vegetação ao longo do percurso: herbácea, arbustiva e arbórea, sendo de destacar a predominância de vegetação herbácea abundantemente constituída por alecrim. Relativamente às características de segurança, atestou-se que existe sinalização de aviso de perigo em dois locais, mas não existe sinalização sobre outras informações, tais como, pontos de interesse, mapa, trajeto, contatos das diversas entidades locais de segurança e emergência. Confirmou-se ainda a inexistência de indicação da capacidade de carga.

No que concerne à avaliação das condições deste percurso e no que respeita aos aspetos do trajeto verificou-se que é facilmente identificável, não existindo obstáculos a impedir o caminho. Detetou-se a existência de cruzamento deste trilho com uma parte do Trilho da Biodiversidade. No entanto, a marcação é explícita e não suscita confusão relativamente ao percurso a seguir. A marcação e sinalética, apesar de ser diferente daquela que é homologada pela FCMP, está correta, encontrando-se em bom estado de conservação. Não se identificou lixo ao longo do percurso nem danos evidentes na vegetação adjacente 
ao trilho. Todo o percurso se encontra bem delineado. Apenas detetaram-se, pontualmente, alguns problemas de drenagem do trilho os quais se refletem em poças de água.

\section{b) Trilho da Biodiversidade:}

Tem uma extensão de $1.8 \mathrm{Km}$, sendo um percurso diferente de todos os outros percursos, pois engloba uma vertente pedagógica e de educação ambiental. Ao longo do trajeto podemos encontrar oito painéis informativos que possuem informação sobre a biodiversidade presente. É um projeto integrado na Rede de Estações da Biodiversidade / Rota de Monitorização da Biodiversidade, de âmbito Nacional (fonte: Município do Cadaval). O tipo de solo é essencialmente argiloso e pedregoso. A sinalização é própria, constituída por placas direcionais e informativas específicas, não correspondendo, no entanto, à sinalética homologada pela FCMP. Pode ser realizado durante o ano todo, privilegiando-se as visitas guiadas para uma melhor e mais eficaz sensibilização dos visitantes. $\mathrm{O}$ trajeto encontra-se perfeitamente desobstruído de obstáculos. A visibilidade do trilho é boa, sendo facilmente identificável ao longo de todo o percurso. Existe uma interceção deste trilho com o Trilho Quinta da Serra e também com o Trilho dos Currais e Calçada mas que, pelas diferenças de sinalética, pela boa sinalização dos percursos e pelo seu bom estado de conservação, não gera dificuldade relativamente ao trajeto a tomar. Este revela-se um percurso seguro, não tendo sido identificada nenhuma situação que possa constituir perigo para os praticantes, tais como a queda de pedras ou de árvores, animais selvagens perigosos ou zonas perigosas mal sinalizadas.

\section{c) Trilho dos Currais e Calçada:}

É um percurso com uma extensão de cerca de seis $\mathrm{Km}$, do tipo circular e que demora, em média, cerca de duas horas a percorrer, sendo o solo do tipo pedregoso e rochoso. $O$ ponto mais baixo deste percurso situa-se a uma altitude de 354 metros e o ponto mais alto atinge uma altitude de 551 metros. A sinalética distribuída pelo trilho não é homologada, de acordo com a FCMP. Podemos encontrar todo o tipo de vegetação, sendo a do tipo arbustivo dominante ao longo deste trajeto. Como infraestruturas de apoio, encontram-se as que estão adstritas ao Parque de Campismo (balneários masculinos e femininos com chuveiros e instalações sanitárias), o café junto ao Parque de Merendas e estacionamento. Os principais elementos de interesse ao longo do Trilho dos Currais e Calçada são, a já referida Calçada dos Frades, o Covão das Pias que, a par de outros covões, é um espaço de cultivo de produtos agrícolas para subsistência das populações locais. Pode realizar-se durante o ano inteiro, sem qualquer restrição e não possui, também, informação ou limitação acerca da sua capacidade de carga. A avaliação efetuada ao trajeto revela a boa condição deste no que respeita a obstáculos a impedir o caminho ou à identificação do início e final do trilho. Contudo, verificaram-se alguns pontos (curtos) do percurso que não são facilmente identificáveis, devido à intensidade da vegetação, a qual se desenvolve rapidamente se não houver uma manutenção adequada por parte da entidade responsável. A sinalética, apesar de não ser devidamente homologada, está correta. No entanto, consideramos que existe um certo excesso de sinalização, ou seja, existem marcações ao longo do percurso que se verificam desnecessárias, não acrescentando informação nova e relevante para a realização do mesmo. Julgamos aconselhada a sua remoção, no sentido de causar o mínimo impacte possível na paisagem. A conservação do meio é boa, não existem problemas de drenagem ou vegetação adjacente ao trilho danificada. Apenas consideramos alguma falta de manutenção em determinados pontos, nomeadamente na delimitação do trilho. Quanto à segurança, dos aspetos analisados, não se constatou qualquer problema.

\section{d) Trilho dos SS:}

O Trilho dos SS percorre um trajeto de cerca de $8 \mathrm{Km}$, do tipo circular. Demora, em média, entre duas horas e meia a três horas a percorrer. A vegetação que predomina ao longo deste percurso é do tipo herbácea, havendo também vegetação arbustiva e arbórea. Com um relevo montanhoso, verificamos um desnível máximo de 280 metros entre o ponto mais baixo e o ponto mais alto do percurso. Este trilho contém variados pontos de interesse cultural e natural: além das paisagens que proporciona, identificamos o Vale da Cascalheira ou Vale da Ramada, a passagem pela Igreja da Nossa Senhora das Neves, Capela de São João e pelas ruínas do Convento Dominicano. Nos aspetos que concernem ao trajeto, verificámos a existência de algumas pedras soltas, o que pode pôr em causa a segurança dos praticantes e dificultar a sua progressão no terreno. Por outro lado, não se identificaram obstáculos a impedir o caminho nem cruzamentos com outros percursos sinalizados. A sinalética encontra-se adequada e em bom estado de conservação.

\section{Discussão}

De acordo com Maciel, Paolucci, e Ruschmann (2008) os estudos sobre a Capacidade de Carga devem privilegiar a definição de níveis desejáveis de visitação inicial, estabelecendo uma margem de segurança considerável, bem como definir indicadores para a sua monitorização, prevendo ajustes regulares em função dos impactes verificados. Neste contexto, verifica-se que nenhum dos locais de prática analisados possui uma capacidade de carga definida o que, corroborando o exposto por Alves, Rodrigues, e Carvalhinho (2013), poderá constituir uma verdadeira ameaça no que respeita à 
sustentabilidade destes espaços e dos respetivos ecossistemas, concordando também com Costa (2006), quando enuncia que a sustentabilidade das atividades por via da preservação e conservação das infraestruturas, recursos e produtos de um local é garantida através da monitorização e cumprimento da capacidade de carga.

No que respeita à prática de Escalada, concordamos com FCMP (2014) quando refere que o equipamento fixo de uma via de escalada pode ser um fator determinante para a sua popularidade, dependendo da quantidade e da qualidade do mesmo, pois as vias mais bem equipadas são escaladas com maior frequência, já que transmitem uma maior sensação de segurança. Confirma-se através dos resultados obtidos que, nos setores avaliados, grande parte das vias encontram-se devidamente equipadas, existindo apenas a necessidade de substituição de alguns equipamentos fixos.

Se estiverem bem definidos e corretamente geridos, os percursos pedestres podem funcionar como instrumentos de ordenamento dos territórios (Ventura et. al, 2009). Após a aplicação de instrumentos de caracterização e avaliação nos percursos pedestres estudados, verifica-se que estes exaltam os valores patrimoniais de uma região, procurando conciliar os valores naturais com os valores culturais. Tal como afirma Tovar (2010), estas são algumas das características específicas dos territórios de montanha que contribuem para a importância destes locais como cenários privilegiados de atividades de lazer. No entanto, identifica-se a necessidade de projetar para os praticantes mais alguma informação útil, nomeadamente, as tipologias de interesse dominantes nos percursos.

\section{Considerações Finais}

Apresentando a Área Protegida em estudo um número reduzido de investigações, pretendeu-se contribuir para o aumento do conhecimento científico e, ao mesmo tempo, fornecer ferramentas válidas que contribuam para o desenvolvimento da prática de atividades de desporto de natureza e turismo ativo e que tenham aplicabilidade no campo da gestão desta paisagem protegida.

A monitorização regular dos locais de prática de atividades desportivas na natureza e de turismo ativo e do seu espaço envolvente é condição essencial para impedir a degradação dos mesmos. Locais degradados prejudicam a estética desta Área Protegida e tornam as condições de prática menos atraentes e mais inseguras.

Os municípios envolvidos não possuem informação suficiente e consensual no que respeita aos locais de prática de atividades desportivas na natureza e turismo ativo, carecendo de regulamentação específica. Revela-se, assim, fundamental a elaboração de uma Carta de Desporto de Natureza que identifique estes locais e regule a sua prática.
Os percursos pedestres analisados encontram-se bem marcados, guiando o praticante sem suscitar qualquer dúvida ao longo dos trajetos. Contudo, estes percursos não estão homologados pela FCMP (nem as suas marcações são oficiais), constituindo assim, barreiras no plano da promoção nacional e internacional dos mesmos, principalmente através de entidades oficiais. Por outro lado, a não homologação destes percursos não confere a obrigatoriedade da entidade gestora efetuar regularmente manutenção aos mesmos, podendo ter como consequência, problemas ao nível da sua conservação.

Os setores de escalada do Montejunto Velho - Penha do Meio Dia não possuem acessos definidos. A prática de escalada nestes setores só é possível de realizar entre os meses de agosto e janeiro devido à nidificação de aves neste local nos restantes meses do ano. A limitação temporal da prática dificulta a manutenção dos acessos, pois a vegetação encarregase de os eliminar totalmente. Devem, contudo, criarse acessos específicos permanentes, minimizando assim o risco de destruição da flora pelos praticantes através do pisoteio e até mesmo do corte de vegetação para conseguirem chegar aos setores.

A sinalização existente no setor de Escalada do Montejunto Velho - Penha do Meio Dia encontra-se danificada, pouco enquadrada com a paisagem e pouco visível, devendo a mesma ser substituída por outra com uma estrutura harmonizada com a paisagem envolvente e colocada em local bem visível.

Em ambos os setores de escalada avaliados, confirma-se uma adequação da grande maioria dos equipamentos fixos das vias, possibilitando assim, uma prática segura e em diversas vias com diferentes graus de dificuldade.

Existe, contudo, a necessidade de uma manutenção periódica destes locais de prática, tanto ao nível do equipamento como das acessibilidades, sob pena de ocorrer uma degradação irremediável das estruturas e impossibilitar a prática de atividades de desporto de natureza e turismo ativo. Verifica-se ainda a necessidade de identificação de novos locais de prática e sinalização de novos percursos que possibilitem a prática de novas modalidades e, ao mesmo tempo, impossibilitem os praticantes de realizar determinadas atividades em locais não aconselhados, podendo perturbar ou até destruir a fauna e a flora existentes.

\section{Referências}

Alves, A., Rodrigues, M. L., \& Carvalhinho, L. (2013). Cartas de desporto de natureza. Contributo para um modelo de gestão e monitorização. Revista da Unidade de Investigação do Instituto Politécnico de Santarém, 1(1), 194-208. 
Brandão, B. (2011). Avaliação da qualidade dos percursos pedestres homologados em Portugal (Mestrado). ESHTE, Estoril.

Buckley, R. (2004). Environmental impacts of ecotourism. New York: CABI Pub. http://dx.doi.org/10.1079/9780851998107.0000

Carvalhinho, L., \& Rosa, P. (2012). Avaliação de espaços de prática desportiva: Contributo para a revisão da carta de desporto de natureza do Parque Natural das Serras de Aire e Candeeiros (PNSAC). Paper presented at the $2^{\circ}$ Congresso da Sociedade Científica de Pedagogia do Desporto, UTAD, Vila Real.

Carvalhinho, L., \& Rosa, P. (2013). Avaliação dos percursos pedestres do Parque Natural das Serras de Aire e Candeeiros. Paper presented at VI International Tourism Congress - ESTM, Peniche.

Costa, C. (2006). Tourism planning, development and the territory. In D. Buhalis \& C. Costa (Eds.), Tourism management dynamics: Trends, management and tools (236-243). ButterworthHeinemann.

FCMP (2014). Linhas de orientação para a instalação ou requalificação de equipamento em locais naturais de escalada em rocha. Documento técnico. Lisboa.

Hadwen, W., Arthington, A., Boon, P., Lepesteur, M., \& McComb, A. (2006). Rivers, streams, lakes and estuaries: Hot spots for cool recreation and tourism in Australia. Gold Coast Queensland. Cooperative Research Centre for Sustainable Tourism, Griffith University.

Hadwen, W., Arthington, A., \& Boonington, P. (2008). Detecting visitor impacts in and around aquatic ecosystems within protected areas. Gold Coast, Queensland. Cooperative Research Centre for Sustainable Tourism, Griffith University.

Hardiman, N., \& Burgin, S. (2011). Canyoning adventure recreation in the Blue Mountains World Heritage Area (Australia): The canyoners and canyoning trends over the last decade. Tourism Management, 32(6), 1324-1331. http://dx.doi.org/10.1016/j.tourman.2011.01.002

Maciel, N., Paolucci, L., \& Ruschmann, D. (2008). Capacidade de carga no planejamento turístico: Estudo de caso da Praia Brava - Itajaí frente à implantação do Complexo Turístico Habitacional Canto da Brava. Revista Brasileira de Pesquisa em Turismo, 2(2), 41-63. doi: http://dx.doi.org/10.7784/rbtur.v2i2.102

Mende, P., \& Newsome, D. (2006). The assessment, monitoring and management of hiking trails: A case study from the Stirling Range National Park,
Western Australia. Conservation Science Western Australia, 5(3), 285-295.

Municipio do Cadaval - www.cm-cadaval.pt

Newsome, D., Dowling, R. K., \& Moore, S. A. (2005). Wildlife tourism. Clevedon: Channel View Publications.

Paixão, J., Costa, V., \& Gabriel, R. (2009). Esporte de aventura e ambiente natural: Dimensão preservacional na sociedade de consumo. Motriz, 15(2), 367-373.

Pereira, F., Canhoto, J., Mateus, P., Rosa, P., \& Carvalhinho, L. (2012). Avaliação, classificação e qualificação de espaços de escalada no Parque Natural das Serras de Aire e Candeeiros (PNSAC): O setor de Lapas de Alcaria, Concelho de Porto Mós. Poster presented at IV Jornadas de Desporto de Natureza e Turismo Ativo - Jornadas Tecnico-científicas de Desportos de Montanha, Rio Maior.

Pickering, C. M., Hill, W., Newsome, D., \& Leung, Y.-F. (2010). Comparing hiking, mountain biking and horse riding impacts on vegetation and soils in Australia and the United States of America. Journal of Environmental Management, 91(3), 551-562.

http://dx.doi.org/10.1016/j.jenvman.2009.09.025.

Randall, M., \& Newsome, D. (2008). Assessment, evaluation and a comparison of planned and unplanned walk trails in coastal south-western Australia. Conservation Science Western Australia, 7(1), 19-34.

Rosa, P., \& Carvalhinho, L. (2012). A educação ambiental e o desporto na natureza: Uma reflexão crítica sobre os novos paradigmas da educação ambiental e o potencial do desporto como metodologia de ensino. Movimento, 18(23), 259280.

Rosa, P., Raimundo, P., Sanz, R., Silveira, F., \& Carvalhinho, L. (2012). Avaliação dos percursos pedestres do Parque Natural das Serras de Aire e Candeeiros pertencentes ao Concelho de Santarém. Paper presented at the $2^{\circ}$ Congresso da Sociedade Científica de Pedagogia do Desporto, Vila Real.

Rosalino, L. M., \& Grilo, C. (2011). What drives visitors to Protected Areas in Portugal: accessibilities, human pressure or natural resources. Journal of Tourism and Sustainability, 1(1), 3-11.

Steven, R., Pickering, C., \& Guy Castley, J. (2011). A review of the impacts of nature based recreation on birds. Journal of Environmental Management, 92(10), 2287-2294.

http://dx.doi.org/10.1016/j.jenvman.2011.05.005 
Tovar, Z. (2010). Pedestrianismo, percursos pedestres e turismo de passeio pedestre em Portugal (Mestrado). ESHTE, Estoril.

Turton, S. (2005). Managing environmental impacts of recreation and tourism in rainforests at the Wet Tropics of Queensland World Heritage Area. Geographical Research,43,140-151.

Ventura, M., Queiroz, R., Resendes, R., Marquet, N., \& Melo, J. (2009). Caracterização e avaliação dos percursos pedestres da Ilha de Santa Maria. XIV Expedição Científica do Departamento de Biologia - Santa Maria 2009. Rel. Comp. Dep. Biol., 36, 167-182. 


\title{
Intervenção Pedagógica no Desporto de Natureza: Atividades em Tempos de Pandemia Covid19
}

\author{
Pedro Bento $^{1}$, Luís Murta ${ }^{1}$ \\ ${ }^{1}$ Escola Superior de Educação - Instituto Politécnico de Beja

\begin{abstract}
Palavras-chave
Desporto de

Natureza;

Turismo ativo;

atividades;

Intervenção

Pedagógica.

\section{RESUMO:}

O Desporto de Natureza é um dos setores de crescimento mais rápido, na área do turismo ativo, englobando muitos tipos de atividades. Neste sentido, é importante investigar a forma como as empresas especializadas na área enquadram as suas atividades no mercado, tentando identificar parâmetros e condicionantes que determinam a qualidade das mesmas, propondo melhorias nos processos e procedimentos (Alves, 2010; Bento, 2017; Mediavilla et al., 2014). Neste contexto, é necessário uma capacitação e qualificação por parte dos técnicos responsáveis, bem como um compromisso físico e psicológico por parte do cliente final. Neste artigo pretende-se caracterizar a implementação de três atividades de desportos de natureza, por área/ambiente de intervenção (terra, água e ar) de acordo com Serra (2009), adaptando normas, procedimentos técnicos e de segurança, tendo em conta a evolução do atual surto epidémico resultante, da pandemia de COVID-19, declarada pela Organização Mundial de Saúde (OMS) em março de 2020. Os procedimentos de segurança e higiene implementados pelas empresas, resultantes da pandemia COVID-19, devem perpetuar-se no tempo, onde surgirão oportunidades para refletir e repensar o turismo e as atividades de Desporto de Natureza.
\end{abstract}

\section{Keywords}

Nature Sport;

Active Tourism;

Activities;

Quality Lessons

\section{Pedagogical intervention in nature sports - Activities during the pandemic}

\section{ABSTRACT:}

Nature Sports is one of the fastest growing sectors in active tourism area, with many types of activities. In this sense, it is important to investigate the way that specialized companies in the area provide their activities, trying to identify the parameters and constraints that determine the quality, proposing improvements in processes and procedures (Bento, 2017; Mediavilla et al., 2014). In this context, it's necessary a qualification in the technicians and guides as well as a physical and psychological commitment, on the part of the final customer. The identification of the parameters of the activities promoted by specialized companies, make current and pertinent, more investigations in an increasingly and important sector. This article aims to characterize the implementation of three active tourism activities, divided by area / environment of intervention (land, water and air) according to Serra (2009), adapting standards, technical and safety procedures, taking into account the evolution of the current outbreak resulting from the COVID19 pandemic, declared by the World Health Organization (WHO), in March 2020.

The safety and hygiene procedures implemented by companies, resulting from the pandemic COVID-19, should be perpetuated in time, where opportunities will arise to reflect and rethink tourism and Nature Sport activities. 


\section{Intervenção pedagógica no desporto de natureza: Atividades em tempos de pandemia Covid19}

Sistematizar e adequar as atividades de desporto de natureza, de acordo com a especificidade de cada serviço ou produto, é fundamental para que a intervenção de cada um dos agentes participantes (técnicos/monitores e clientes), possa ser enquadrada e monitorizada de forma segura e eficaz (Bento, 2017).

O sucesso deste tipo de atividade, depende da qualidade da experiência vivenciada (Redmond et al, 2010). Neste sentido, é necessário ter em conta diversos fatores, como por exemplo: o cumprimento dos objetivos propostos (de acordo com as caraterísticas de cada grupo), a organização e gestão dos participantes desde o briefing inicial até ao final da atividade (feedbacks claros, incisivos e adaptados) e ainda as funções e competências do técnico/monitor responsável, que orienta o grupo desde o primeiro momento. O conjunto de todos os fatores atrás referenciados, contribuem para a fruição "experiencial" deste tipo de atividades (Carvalhinho et al., 2013).

Investigações recentes sobre os efeitos da COVID19, apontam para danos irreparáveis nos destinos de turismo de aventura, se não existir uma mudança de paradigma, isto é, se os seus produtos e atividades não forem repensados, tendo em conta todas as condicionantes atuais de saúde pública (Macdonald, 2020; Newsome, 2020).

Deverá priorizar-se a qualidade em vez da quantidade, proporcionando um desenvolvimento sensato de novas atividades (Nepal, 2020).

Atualmente, todos os agentes turísticos e desportivos tiveram de se adaptar e tomar medidas extraordinárias complementares, tentando minimizar os efeitos da propagação aos diferentes intervenientes das atividades e à população em geral, orientando os procedimentos para melhores práticas (APECATE, 2020). Os planos de contingência, expressos na orientação 006/2020 da Direção Geral de Saúde (DGS), permitiram às empresas, uma adequação segura e adaptada à sua realidade.

As atividades de Desporto de Natureza, permitem aos participantes uma experiência pessoal positiva, aumentando a sua autoestima e promovem ainda, um contato direto com os espaços naturais e sua envolvente (Júnior \& Lobo, 2012; Kane, 2010).

Devido ao seu contexto e caraterísticas, estas atividades envolvem na sua maioria decisões antecipadas, que visam minimizar o risco associado, identificando e monitorizando todos os procedimentos específicos em cada uma das ações práticas (Ennes, 2013).

Para Vidal, (2011, p. 17) "a gestão de riscos é parte integrante da construção da segurança, pois é o desejo do domínio do risco que nos leva ao pensamento e decisão sobre quais os procedimentos e atitudes que podem acrescentar segurança, com a correspondente diminuição ou mesmo controlo do risco".

Os dados e planeamento que iremos apresentar, estão baseados na experiência atual de organização, no espaço natural, deste tipo de serviços e atividades, com todos os constrangimentos resultantes da pandemia COVID-19, através da observação participante de 3 tipos de atividades de uma empresa de Animação Turística.

\section{Método}

Para conseguir avaliar a intervenção pedagógica nas atividades de desporto de natureza, resultante do enquadramento atrás referenciado, desenvolvemos uma metodologia de recolha de dados, através do contato direto com uma empresa especializada na área, num contexto metodológico de estudo de caso (Bogdan, R., \& Biklen, S., 2010), estabelecendo uma relação entre a intervenção dos profissionais e o contexto socioprofissional onde se inserem e desenvolvem e sua atividade.

Em termos concretos procedemos à observação participante (Bogdan \& Biklen, 2010) nas três fases de operacionalização das atividades, a saber: a fase inicial (briefing inicial), a fase de desenvolvimento da atividade e a fase de conclusão.

\section{Participantes}

Para a realização do presente estudo, visando a obtenção de resultados através da observação de atividades e registo de procedimentos técnicos adaptados à especificidade da área, recolhemos informação relativa às empresas de Animação Turística, presentes no RNAAT (registo nacional dos agentes de animação turística) com vista à identificação da empresa a selecionar para o estudo.

De acordo com a análise efetuada, e tendo em conta a proximidade geográfica, a experiência no terreno e a diversidade de atividades e serviços, escolhemos uma empresa que trabalha nesta área desde 2006 e que dispõe de um leque abrangente de atividades nos diferentes ambientes (terra, água e ar). A referida empresa conta com 4 colaboradores a tempo inteiro nos seus quadros, desenvolve a sua atividade junto de diversos parceiros (públicos e privados), animando de forma efetiva, durante todo o ano, o território onde está inserida.

As atividades selecionadas e analisadas no estudo (Passeio guiado moto 4, canoagem e voo em balão de ar quente) desenvolveram-se nos meses de junho e julho de 2020.

Foram realizadas duas observações para cada tipo de atividade, perfazendo um total de seis atividades analisadas.

No conjunto participaram no estudo um total de 51 clientes e cinco monitores/técnicos da empresa.

Os clientes estavam organizados em grupos família ou participantes individuais. 
Os monitores/técnicos são colaboradores permanentes da empresa.

\section{Instrumentos}

Para a observação das atividades foi elaborada uma grelha de observação e registo (tabela 1), adaptada às diferentes fases e ações da atividade, onde se procuram identificar os procedimentos técnicos e práticos, adotados pelos agentes envolvidos nas diversas etapas de cada atividade.

A recolha de dados foi feita através da observação direta e participante das atividades desenvolvidas pela empresa com os clientes, com recurso à grelha referida (tabela 1). Os dados apresentados traduzem o procedimento padrão adotado no conjunto das três observações para cada atividade.

Tabela 1. Tabela descritiva com identificação de processos, ações e pontos críticos

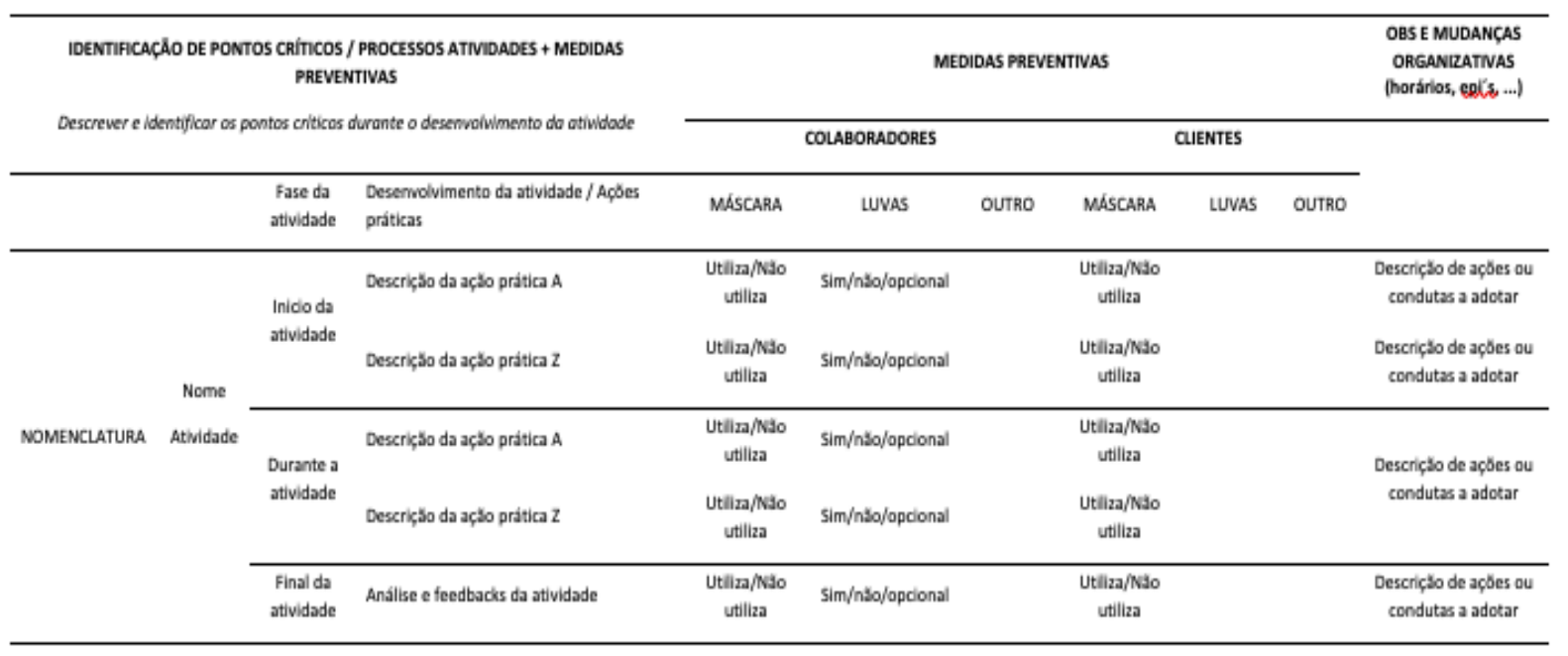

O preenchimento e análise desta grelha permitiu a posterior adaptação de medidas de prevenção relacionadas com a pandemia COVID 19, através da "identificação dos pontos críticos", tendo como base os pressupostos de segurança e higiene, emanadas pelo organismo regulador em Portugal - A Direção Geral de Saúde (DGS).

Tendo em conta todas as condicionantes de segurança e a especificidade dos locais onde são realizadas, adequámos para cada uma das atividades observadas, ações práticas e medidas de contenção a implementar na realização das mesmas, que descreveremos, como resultado prático da análise no terreno.

Através da observação direta, inserimos e preenchemos os campos "medidas preventivas" no qual descrevemos as opções de proteção para os colaboradores da empresa que presta o serviço e também para os clientes, em cada uma das fases da atividade. Colocámos ainda um campo de "observações e mudanças organizativas", onde inserimos alterações inerentes ao funcionamento interno da empresa, resultantes do desenvolvimento deste tipo de medidas, bem como a descrição de algumas tarefas ou condutas especificas a adotar durante a atividade. De referir que todas as observações e medidas descritas na grelha, resultaram da interação e feedbacks sugeridos por parte do responsável e colaboradores da empresa.

\section{Procedimentos}

Para realizar a recolha de dados, efetuámos duas reuniões preparatórias com o responsável da empresa, para autorizar a recolha, planear as datas e procedimentos práticos.

Para se proceder à análise técnica, explicada anteriormente, foram identificadas três atividades dinamizadas pela empresa, de nomenclaturas e ambiente de realização diferentes. As atividades escolhidas foram: a moto 4 (em regime de passeio guiado), a canoagem e o voo em balão de ar quente. A recolha de dados iniciou-se com as atividades moto 4 e canoagem, tendo o voo em balão de ar quente, aguardado a meteorologia ideal para a realização da atividade em segurança, de acordo com os padrões definidos pela empresa.

Este processo decorreu durante cerca de três semanas, tendo sido observados seis momentos práticos (dois por cada atividade).

\section{Resultados}

Neste capítulo apresentamos os resultados, respeitantes aos parâmetros técnicos, de segurança e às medidas de contenção e higiene inerentes à pandemia COVID 19, implementados nas atividades - Passeio Guiado Moto 4, Canoagem e Voo em balão de ar quente.

- Passeio Guiado Moto 4 
Conforme se observa na tabela 2 , os resultados relativos à recolha de dados no terreno, realizados no âmbito da atividade - Passeio Guiado Moto 4 subdividem-se em três fases.

Tabela 2. Passeio Guiado Moto 4 - identificação de processos, ações e pontos críticos

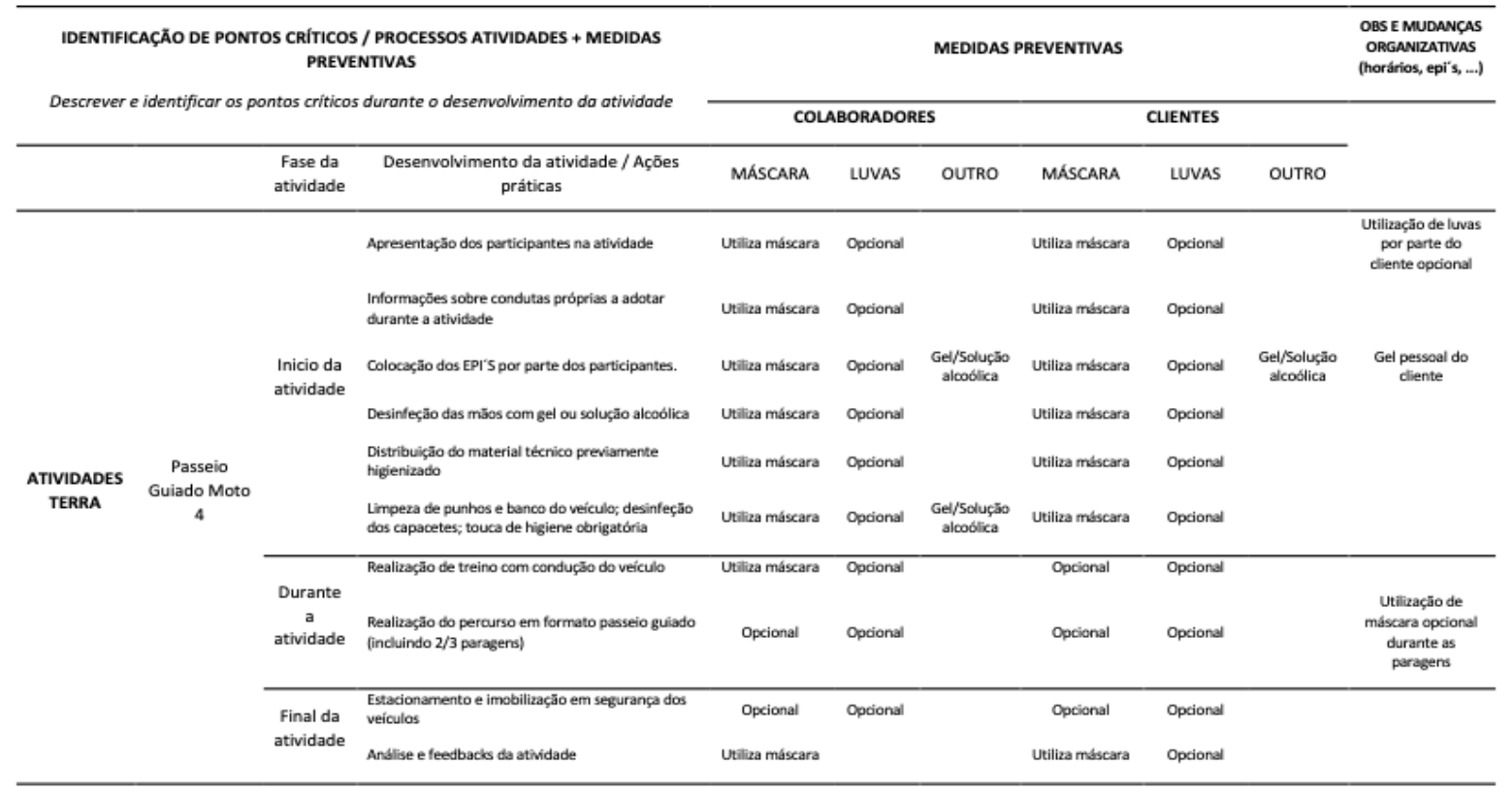

A fase inicial desta atividade é caraterizada pela explicação, por parte do monitor responsável, do conteúdo e formato do serviço ao cliente. São abordados alguns requisitos básicos para a participação na atividade.

As normas e regras, são reforçadas na fase seguinte da atividade - treino prático de adaptação. Nesta fase, apesar dos procedimentos e feedbacks ocorrerem ao ar livre, recomenda-se o uso de máscara por parte do monitor, pela necessidade de interação e distância de segurança que é fundamental adotar. A higienização dos equipamentos também deverá estar assegurada antes da entrega aos participantes.

Durante o percurso, o monitor responsável gere o grupo, de acordo com as características e nível de desempenho dos participantes resultante do treino de adaptação anterior. Neste sentido poderão efetuar-se 2 ou 3 paragens para resolver algum problema ou dificuldade técnica que ocorra ou apenas fazer referência a pontos históricos, culturais ou naturais que surjam durante o percurso. Nesta fase, e se forem mantidas as regras de segurança, o uso de máscara pode considerar-se opcional.

No final do passeio o monitor deverá tentar recolher a opinião e sensações dos participantes, relativamente à atividade que acabaram de realizar, salvaguardando o cumprimento das regras de distanciamento e usando a máscara de proteção.

\section{Canoagem}

No que concerne à atividade de canoagem, no início, após o enquadramento técnico realizado pelo monitor, os participantes efetuam o primeiro contacto com o material que irão utilizar e são instruídos sobre a forma correta de utilização do mesmo, dentro e fora de água. Nesta fase, é essencial a pré-higienização dos equipamentos de proteção individual (EPI'S), bem como o uso de máscara por parte do monitor, no respeito pelas regras de distanciamento pessoal.

Durante a realização da atividade, tendo em conta as caraterísticas da mesma e assegurando as regras de segurança e distanciamento, não será necessário o uso de máscara por parte dos intervenientes.

No final, após a colocação dos participantes em local de segurança e recolha dos materiais, procede-se à avaliação final da atividade. Recomenda-se novamente o uso de máscaras por parte do monitor responsável.

\section{Voo em balão de ar quente}

$\mathrm{O}$ voo em balão de ar quente inicia-se com o transfer dos participantes desde o local combinado (hotel, cidade, vila ou outro) até ao ponto onde se inicia a atividade. Todo o trajeto deve contemplar o uso de máscara por parte dos passageiros e condutor da viatura. De referir ainda que a empresa adotou as normas de transporte emanadas pelas entidades reguladoras (DGS, 2020; APECATE, 2020), limitando a $1 / 3$ a ocupação dos diferentes tipos de veículos. 
Tabela 3. Canoagem - identificação de processos, ações e pontos críticos

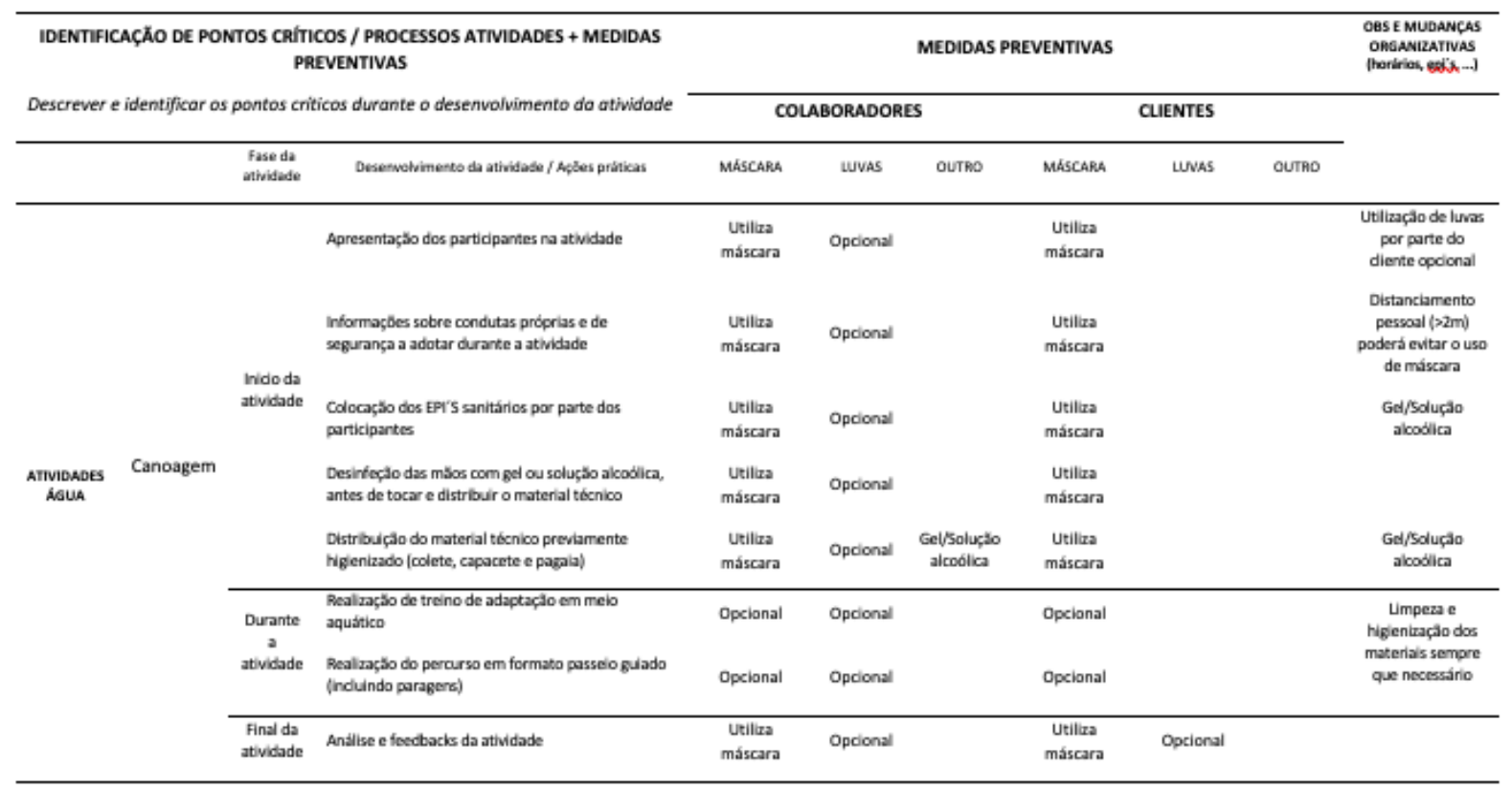

Tabela 4. Voo em balão de ar quente - identificação de processos, ações e pontos críticos

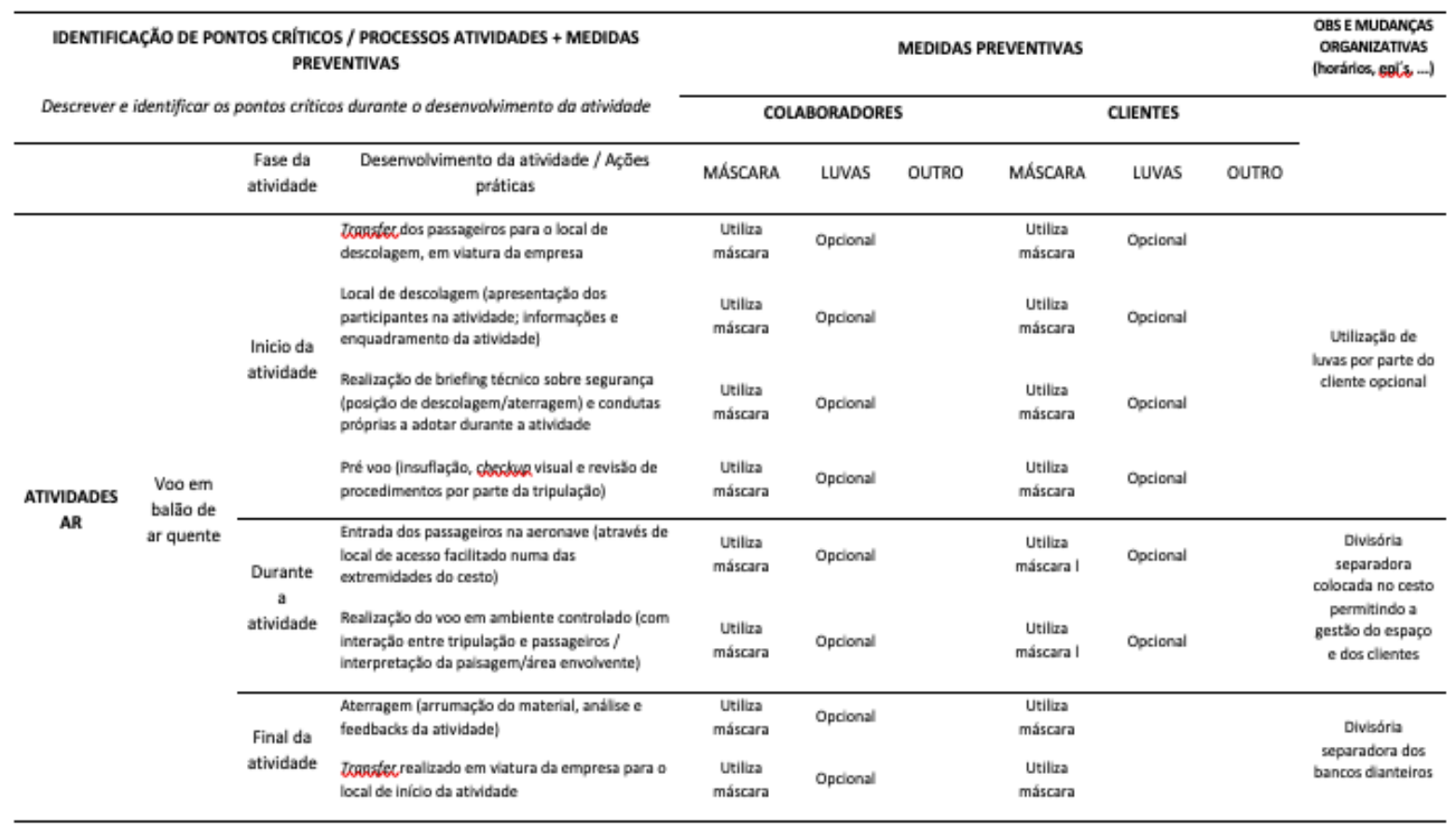

Na parte inicial da atividade é realizado o briefing de segurança, junto da aeronave e explicados todos os procedimentos de entrada e saída do equipamento, bem como a conduta a adotar durante o voo. Neste período, o monitor responsável deve usar a máscara, tal como todos os participantes.

Após este período de enquadramento, os participantes assistem à fase final de preparação do voo, mantendo as distâncias de segurança.

Durante o voo, os participantes encontram-se separados por uma divisória colocada no cesto, que por si já é compartimentado, gerindo desta forma o distanciamento social. A colocação de máscaras é obrigatória durante o voo. O piloto usa sempre a máscara durante o decorrer da atividade.

No final, o monitor realiza o balanço da atividade, salvaguardando as regras de distanciamento e usando a máscara de proteção. 


\section{Discussão}

Depois de apresentados os resultados, procedemos à confrontação dos dados obtidos, tendo em conta a realidade observada e os procedimentos específicos adotados pela empresa participante no presente estudo, com os dados mais relevantes registados em estudos de referência na área.

Com o surgimento da pandemia COVID 19, todas as empresas nos diferentes setores económicos, viramse obrigadas à adoção de novas medidas inerentes ao funcionamento dos seus serviços/atividades (UNWTO, 2014; 2020).

As atividades de desporto de natureza tal como os demais setores, estão a passar por um período de adaptação à nova realidade, onde o desafio principal é o de continuar a ter capacidade de promover, organizar e proporcionar serviços e experiências diferenciadas aos seus clientes, onde 0 fator segurança não pode ser descurado (WTO, 2020). Novos procedimentos, são essenciais para que exista uma aprendizagem prática, contextualizada e segura (Kane, 2010; Mackenzie \& Goodnow, 2020).

O uso de máscara assertivo e generalizado por parte dos monitores é talvez o aspeto mais relevante (Greenhalgh et al., 2020), tendo em conta o número de vezes que repetem procedimentos e ações, muito particularmente no contacto direto que são obrigados a manter com os diferentes clientes. Já os participantes, dependendo do tipo de grupo que formam (família e/ou grupo de amigos), assim se recomenda ou solicita, o uso continuado de máscara, no decorrer da atividade, tendo em conta também a tipologia e espaço de organização. De referir ainda, que a atividade onde se adotou mais este procedimento, foi o voo em balão de ar quente, no qual os passageiros estão confinados num espaço mais restrito.

Outro aspeto que, tal como já acontecia antes (Buckley, 2010; Dabholkar et al, 2000; Cook et al, 2012; Sánchez-Garcia et al, 2011) é agora considerado bastante relevante, é o facto dos participantes (na generalidade) questionarem e querem ver esclarecidas as suas dúvidas no início da atividade sobre as normas específicas, bem como as implicações inerentes à segurança, regras de etiqueta respiratória e distanciamento social (DGS, 2020; Turismo Portugal, IP., 2020; APECATE, 2020; EU, 2020). Denotámos ainda, um cuidado extra com os requisitos relacionados com a limpeza e higienização de espaços e equipamentos, por parte dos monitores/responsáveis de cada atividade.

A procura por uma Aventura Segura, referenciada por Melo et al. (2014), leva a que o risco presente nos programas de atividades deva ser o mais reduzido possível, sem o eliminar, pois desta forma estaríamos a desvirtuar a essência deste tipo de atividades, onde a adrenalina, as emoções e a auto-superação devem estar sempre presentes (Sánchez et al, 2011; Págan, 2012).
A melhoria nos processos de estruturação de serviços e atividades, adaptados à envolvente e público alvo, será sempre um ponto fulcral na continuidade do consumo por parte do cliente, nos tempos atuais, sendo que a personalização da atividade favorece a fidelização do cliente, pela segurança que lhe está associada, resultando num feedback positivo da parte do mesmo, relativamente às suas opções de consumo (Tsitskari et al, 2006; Tremont et al, 2010; Cronin et al, 2000; Brady et al, 2001).

\section{Conclusões}

A conclusões apresentadas, resultam da análise dos procedimentos técnicos e de segurança adotados por uma empresa especializada na área dos desportos de natureza e turismo ativo.

A análise efetuada aos três tipos de atividade, partiu do pressuposto que se trata de serviços já estruturados e implementados no terreno.

Recordamos que as culturas, costumes, formas de comunicação, podem ser distintas nas diversas zonas do país, salvaguardando as demais experiências, perceções e opiniões de outros responsáveis de empresas, tendo em conta o seu know how técnico e prático.

As conclusões presentes neste artigo, refletem o sentido dos dados recolhidos, a experiência profissional de muitos anos de trabalho na área, consolidados com os mais significativos referentes bibliográficos específicos da temática de intervenção, salvaguardando as diferentes perceções que possam existir por parte de responsáveis de diferentes empresas.

Neste sentido, podemos concluir que:

Se deve proceder à definição e homogeneização de procedimentos e normativas relativas ao COVID 19, no mercado do turismo ativo, visando uma uniformização de procedimentos na preparação, organização e implementação das atividades.

Devem ser desenvolvidos, implementados e atualizados os planos de contingência e de ação, com procedimentos a tomar no caso de infeção, aquando da estadia dos clientes nas instalações das empresas, emanados das autoridades de saúde pública e do estado - Direção Geral de Saúde e Turismo de Portugal, IP.

A satisfação dos participantes/clientes, a melhoria da competitividade e o reconhecimento da qualidade do serviço, podem criar um potencial de distinção na oferta, nestes tempos de enormes constrangimentos sociais com que nos confrontamos.

Numa era pós-COVID-19, surgirão oportunidades para repensar o turismo, nomeadamente as atividades aventura, enquadradas nos seus diferentes domínios. Os procedimentos de segurança e higiene implementados pelas empresas, e adaptados a cada um dos serviços/atividades deverão perpetuar-se no tempo, bem como os fatores de risco e segurança, sem adulterar a essência deste tipo de atividades 


\section{Referências}

Alves, A. (2010). Turismo activo: Um produto do turismo e do desporto (Mestrado). Universidade da Madeira. Funchal. Portugal.

APECATE (2020). Associação Portuguesa de Empresas de Congressos, Animação Turística e Eventos. COVID-19 - Guia Geral de Boas Práticas para o Setor da Animação Turística. https://apecate.pt/informacoescovid19/

Bento, P. (2017). La calidad de los servicios de las empresas de turismo activo em Portugal (PhD). Universidad de Huelva. Departamento de Educación Fisica, Música y Artes Plásticas. http://hdl.handle.net/10272/14813

Brady, M., \& Cronin, J. (2001). Some new thoughts on conceptualizing perceived service quality: A hierarquical approach. Journal of Marketing, 65(1), 34-49.

Bogdan, R., \& Biklen, S. (2010). Investigação qualitativa em educação - uma introdução à teoria e aos métodos. Porto: Porto Editora.

Buckley, R. (2010). Adventure tourism management: Great Britain: Elsevier.

Carvalhinho, L., Bento, T., \& Paulo, R. (2013). Desporto, ambiente e turismo ativo: Estado da arte e relações emergentes. Repositório Instituto Politécnico de Santarém.

Cook, M., Gottberg, A., Angus, A., \& Longhurst, P. (2012). Receptivity to the production of product service systems in the UK construction and manufacturing sectors: A comparative analysis. Journal of Cleaner Production, 32, 61-70. doi: http://dx.doi.org/10.1016/j.jclepro.2012.03.018

Cronin, J., Brady, M., \& Hult, G. (2000). Assessing the effects of quality, value, and customer satisfaction on consumer behavioral intentions in service environments. Journal of Retailing, 76(2), 193-218.

Dabholkar, P., Shepherd, C., \& Thorpe, D. (2000). A comprehensive framework for service quality: Investigation of critical conceptual and measurement issues through a longitudinal study. Journal of Retailing, 76(2), 139-173.

EU (2020). Communication from the European Commission. COVID-19: EU Guidance for the progressive resumption of tourism services and for health protocols in hospitality establishments.

https://ec.europa.eu/info/sites/info/files/communicati on_tourismservices healthprotocols.pdf

Ennes, M (2013). Os fatores de risco real nas atividades de montanhismo. Caderno unifoa. $21^{\text {a }}$ Edição. ISSN 1809-9475.
Greenhalgh, T., Dijkstra, P., Jones, N., \& Bowley, J. (2020). Exercising and face masks: An important hypothesis buried in a selective review. Medical Hypotheses, 144, 110255. https://doi.org/10.1016/j.mehy.2020.110255

Júnior, A., \& Lobo, H. (2012). Turismo em cavernas e as representações do mundo subterrâneo. Revista de Turismo y Patrimonio Cultural, 10(5), 585-594.

Kane, M. (2010). Adventure as a cultural foundation: Sport and tourism in New Zealand. Journal of Sport and Tourism, 15(1), 27-44.

Macdonald, N. (2020). A ghost town': With tourist access cut off, Banff unemployment soars. The Globe and Mail. https://www.theglobeandmail.com/business/articlea-ghost-town-with-tourist- access-cut-off-banffunemployment-soars/

Machado, A. L., Bazotti, L. S., \& Vianna, S. L. (2014). A certificação no turismo de aventura: Uma análise do impacto no destino Serra Gaúcha. Caderno Virtual de Turismo,14(2), 101-116.

Mackenzie, S., \& Goodnow, J. (2020). Adventure in the age of COVID-19: Embracing microadventures and locavism in a Post-Pandemic World. Leisure Sciences, http://dx.doi.org/10.1080/ 01490400.2020 .1773984

Mediavilla, L., Gómez, V., Burón, A., \& Valverde, S. (2014). Perfil identificativo de las empresas de turismo de Aventura en España, Italia y Costa Rica. Journal of Sport and Health Research, 6(2), 177-190.

Melo, A. L., Bazotti, L. S., \& Vianna, S. L. (2014). A certificação no turismo de aventura: Uma análise do impacto no destino Serra Gaúcha. Caderno Virtual de Turismo, 14(2), 101-116.

Newsome, D. (2020). The collapse of tourism and its impact on wildlife tourism destinations, Journal of Tourism Futures. https://doi.org/10.1108/JTF-042020-0053

Orientação DGS 006/2020. Procedimentos de prevenção, controlo e vigilância em empresas. https://www.dgs.pt/directrizes-da-dgs/orientacoes-ecirculares-informativas/orientacao-n-0062020-de26022020-pdf.aspx

Pagán, R. (2012). Time allocation in tourism for people with disabilities. Annals of Tourism Research, 39(3), 1514-15317. http://dx.doi.org/10.1016/j.annals.2012.04.005

Redmond, K., Foran, A., \& Dwyer, S. (2010). Quality lesson plans for outdoor education. Human Kinetics.

Sanjay K. Nepal (2020) Adventure travel and tourism after COVID-19 - Business as usual or opportunity to reset?, Tourism Geographies, 22:3, 646-650, http://dx.doi.org/10.1080/14616688.2020.1760926 
Sánchez-García, I., \& Currás-Pérez, R. (2011). Effects of dissatisfaction in tourist services: The role of anger and regret. Tourism Management, 32(6), 1397- 1406. http://dx.doi.org/10.1016/j.tourman.2011.01.016

Serra, P. (2009). Turismo activo no Concelho de Torres Vedras. Contributo para o plano estratégico (Mestrado). Escola Superior de Hotelaria e Turismo do Estoril. Estoril. Portugal.

Tremont, C., \& Hernández, J. (2010). Calidad de servicio (personal en contacto y soporte físico) de los establecimientos de alojamiento del municipio Carirubana Estado Falcón. Pasos.

Tsitskari, E., Tsiotras, D., \& Tsiotras, G. (2006). Measuring service quality in sport services. Total Quality Management \& Business Excellence, 17(5), 623-631.

http://dx.doi.org/10.1080/14783360600588190

UNWTO. (2014). Global report on adventure tourism. World Tourism Organization reports.

Vidal, A. (2011). A Segurança nas atividades de ar livre e de aventura (Mestrado). Universidade Lusófona de Humanidades e Tecnologias. Lisboa.

UNWTO (2020), Covid-19: Putting people first. www.unwto.org/tourism-covid-19-coronavirus

WTO (2020). World tourism barometer - January 2020. 18(1), 1-5, Madrid: UNWTO. 


\title{
Fatores Motivacionais em Desporto de Natureza entre Praticantes e não Praticantes de Exercício Físico
}

\author{
Marta Almeida ${ }^{1}$, Roberta Frontini' ${ }^{2}$, Miguel Correia ${ }^{1}$, António Brandão ${ }^{1}$ \\ ${ }^{1}$ Escola Superior de Desporto e Lazer - Instituto Politécnico de Viana do Castelo (ESDL-IPVC) \\ ${ }^{2}$ Escola Superior de Educação e Ciências Sociais - Instituto Politécnico de Leiria (ESECS-IPL)
}

\begin{abstract}
Palavras-chave Desporto de Natureza e Aventura; Motivações; Exercício Físico.

\section{RESUMO:}

A O propósito do estudo foi perceber quais as motivações para a prática de desporto natureza e aventura, entre praticantes e não praticantes de exercício físico, com a aplicação do questionário EMI-2. A amostra é composta por 764 praticantes, sendo eles portugueses, espanhóis e franceses, das seguintes modalidades: espeleologia, canyoning, canoagem, escalada, BTT, parapente e pedestrianismo. Desses praticantes, 133 praticam exercício físico estruturado, igual ou mais que três vezes por semana (idade média $39 \pm 10.2)$ e 631 não praticam exercício físico estruturado, nunca ou menos de duas vezes por semana (idade média $38.9 \pm 10$ ). Os resultados mais evidentes foram a revitalização o prazer e a afiliação como motivos mais apontados pelos praticantes de DNA. No que diz respeito à comparação entre praticantes e não praticantes de exercício físico, a revitalização, o prazer e a afiliação foram também os mais evidentes.
\end{abstract}

Keywords

Natura and

Adventure Sports;

Motivations;

Physical Exercise.
Motivational factors in nature sport among practitioners and non-practitionres of physical exercise

\section{ABSTRACT:}

O propósito do estudo foi perceber quais as motivações para a prática de desporto natureza e aventura, entre praticantes e não praticantes de exercício físico, com a aplicação do questionário EMI-2. A amostra é composta por 764 praticantes, sendo eles portugueses, espanhóis e franceses, das seguintes modalidades: espeleologia, canyoning, canoagem, escalada, BTT, parapente e pedestrianismo. Desses praticantes, 133 praticam exercício físico estruturado, igual ou mais que três vezes por semana (idade média $39 \pm 10.2$ ) e 631 não praticam exercício físico estruturado, nunca ou menos de duas vezes por semana (idade média 38,9 \pm 10 ). Os resultados mais evidentes foram a revitalização o prazer e a afiliação como motivos mais apontados pelos praticantes de DNA. No que diz respeito à comparação entre praticantes e não praticantes de exercício físico, a revitalização, o prazer e a afiliação foram também os mais evidentes. 


\section{Fatores motivacionais em desporto de natureza entre praticantes e não praticantes de exercício físico}

O exercício físico e o desporto têm diferentes especificidades, mas ambos contribuem para a melhoria da qualidade de vida e bem-estar das pessoas. Identificar as principais razões que motivam as pessoas a praticar exercício e desporto é extremamente importante (Frontini et al., 2019).

Tal caracterização pode ajudar a melhorar os programas de Desporto de Natureza e Aventura (DNA) e encontrar as estratégias mais apropriadas para remover possíveis barreiras a estes géneros de atividade física, nomeadamente espeleologia, canyoning, canoagem, escalada, BTT, parapente e pedestrianismo.

Segundo Brandão (2016), o DNA é apresentado como um desporto distinto, que ocupa e explora lugares na natureza, como a água, a terra e o ar, com diferentes modalidades, como é o caso do surf, canoagem, rafting, canyoning, alpinismo, escalada, asa delta, parapente, entre muitas outras atividades, tendo elas algo em comum, os desafios e emoções que a prática proporciona ao sujeito, surgindo o risco no imaginário de cada indivíduo.

Brandão et al. (2018) reforça que o DNA é uma forma de atividade física, pois através da sua prática, o sujeito tem uma melhoria da sua condição física, técnica e cognitiva, ultrapassando os obstáculos colocados pelo espaço envolvente, que tem por base a natureza. Atualmente, o DNA tem um vasto público, seja a caminhar, escalar, na canoagem, no parapente, tendo como benefício a procura de um lugar especial no comportamento desportivo contemporâneo.

No entanto a preparação física dos praticantes deve ser enquadrada nos objetivos da atividade a ser realizada e deve seguir recomendações sobre a duração, intensidade, frequência e conteúdo da atividade (Potteiger, 2017).

As vantagens que decorrem da prática regular de atividade física são inúmeras, desde os benefícios cardiovasculares até aos psicológicos, sociais e afetivos, que também integram o conceito de saúde holística (Moutão, 2005).

De acordo com os documentos orientadores da Organização Mundial da Saúde, a meta recomendada pela União Europeia e os seus Estados-membros para adultos saudáveis, com idade entre os 18 e os 65 anos, é de 30 minutos de exercício físico de intensidade moderada, cinco dias por semana; ou pelo menos 20 minutos de exercício físico de intensidade vigorosa, 3 dias por semana (Carneiro, 2011).

Os praticantes de exercício físico em ginásios estão mais habituados a ouvir falar dos benefícios da atividade física para a saúde comparativamente com os praticantes de DNA. Portanto, é importante estudar o que motiva a prática de exercício físico que vá de Tabela 1. Caracterização dos participantes encontro às necessidades dos praticantes de DNA para ajudá-los a iniciar ou manter a prática e motiválos a não desistirem (Frontini et al., 2019). Em 2004, Chazaud apresentou um modelo para estudar a motivação dos praticantes de desportos de natureza, de onde se destacavam o prazer em estar em contacto com a natureza, as questões associadas ao risco da prática, as questões sociais, a relação com questões de saúde, a competição e o turismo. No entanto, não existem muitos estudos nesta área. Numa revisão de 2012, Buckley (2012) categorizou em três dimensões os motivos mais encontrados em alguns estudos que procuravam encontrar as motivações para a prática de DNA: desempenho interno da atividade; lugar interno/externo em/na natureza e posição social externa. A nossa equipa de investigação tem-se debruçado sobre estas questões, e alguns estudos têm concluído que os praticantes de ginásio, por exemplo, identificam questões mais relacionadas com a saúde e força comparativamente aos praticantes de DAS (Frontini et al., 2020).

Considerando a quantidade de informação contraditória e a falta de procura de comparação entre modalidades, é importante continuar a estudar o que motiva os praticantes de DNA.

Considerando esta informação, pretendemos com este estudo comparar praticantes de DNA que praticam exercício físico de forma regular e estruturado, com praticantes que não praticam exercício físico de forma regular, quanto às motivações para a prática do exercício físico na prática de espeleologia, canyoning, canoagem, escalada, BTT, parapente e pedestrianismo, através da aplicação do questionário EMI-2, a praticantes de nacionalidade portuguesa, espanhola e francesa. Considerando estudos passados, uma das hipóteses a confirmar será que os praticantes de DNA identificarão motivos mais relacionados com a competição e prazer comparativamente aos praticantes de exercício físico em ginásios que eventualmente identificarão motivos mais relacionados com questões de saúde.

\section{Método}

\section{Participantes}

Este estudo compreendeu a participação de 764 praticantes de DNA, portugueses, espanhóis e franceses, nas seguintes modalidades: espeleologia, canyoning, canoagem, escalada, BTT, parapente e pedestrianismo. Os participantes tinham idade média de $38.9 \pm 10$. Desses praticantes, 133 praticam exercício físico estruturado, igual ou mais que três vezes por semana (idade média $39 \pm 10.2$ ) e 631 não praticam exercício físico estruturado, nunca ou menos de duas vezes por semana (idade média 38.9 \pm $10)$. 


\begin{tabular}{rlcc}
\multicolumn{1}{c}{ Total } & Género \\
\hline & & Masculino & Feminino \\
\hline$N$ & 764 & 604 & 160 \\
Idade $(M \pm D P)$ & $38,90 \pm 10,03$ & $39,04 \pm 10,15$ & $38,41 \pm 9,61$ \\
Anos de prática $(M \pm D P)$ & $10,24 \pm 8,34$ & $10,75 \pm 8,49$ & $8,28 \pm 7,44$ \\
\hline
\end{tabular}

\section{Instrumentos}

Para a obtenção dos dados, foi utilizada a versão em português do Inventário de Exercise Motivations Inventory-2 (EMI-2), adaptada à população portuguesa (Alves \& Lourenço, 2003), espanhola e francesa, tal como já foram aplicados em outros estudos cujos resultados foram já enunciados na introdução (Brandão, Frontini, Peixoto, Fernandes, \& Clemente, 2020; Frontini, Monteiro, Brandão \& Clemente, 2018).

Este inventário é um instrumento que consiste em 51 itens respondidos em uma escala Likert variando de 0 a 5 (sendo que o 0 equivale "não é verdade para mim" e o 5 equivale "é completamente verdade para mim"). Em seguida, os itens são agrupados em 5 dimensões (motivos psicológicos; motivos interpessoais; motivos de saúde; motivos relacionados ao corpo e motivos de condicionamento físico) e 14 fatores: Reconhecimento Social, Saúde Positiva, Peso, Gerenciamento de Estresse, Revitalização, Gozo, Desafio, Afiliação, Concorrência, Pressões de Saúde, Evitar Saúde, Aparência, Força e Resistência e Agilidade (Markland \& Ingledew, 1997).

\section{Procedimentos}

Recolha de dados: os praticantes de DNA foram contactados através de clubes, associações, federações e redes sociais. Para participarem neste estudo os praticantes validaram um termo de consentimento. Os dados obtidos neste questionário foram recolhidos e analisados de forma anónima, garantindo sempre o princípio da confidencialidade. $\mathrm{O}$ questionário foi aplicado online na plataforma Survey Monkey, onde foi testada por 5 praticantes de DNA e 3 professores portugueses, 3 de espanhol e 3 de francês. Foi dado sugestões de melhoria no que diz respeito a termos utilizados, na semântica e na parte gramatical o que levou a haver alguns ajustes por parte dos investigadores. Os praticantes, para responder a este questionário, demoraram entre 15 a 20 minutos.

\begin{abstract}
Análise estatística
As variações, entre os participantes de DNA que praticam exercício físico estruturado e os que não praticam de forma estruturada, foram analisadas usando as diferenças padronizadas do tamanho do efeito (ES) com 90\% do Intervalo de Confiança (IC). A escala $(<0,2$, trivial; 0,2-0,6, small; 0,6-1,2, moderate; $>1,2$, large), foi usada para interpretar $\mathrm{o}$ efeito de magnitude. As probabilidades foram testadas considerando as smallest worthwhile changes (SW, 0,2 $\mathrm{x}$ entre SD sujeitos). Para as probabilidades qualitativas usou-se a seguinte escala: $25-75 \%$, possivelmente; $75-95 \%$, provável; $95-99 \%$ muito provável; e> 99\% quase certo.
\end{abstract}

\section{Resultados}

Foram feitas comparações de categorias de motivação para a prática de DNA, entre praticantes que não praticam exercício físico, praticantes que praticam exercício físico duas vezes por semana e praticantes que praticam 3 vezes exercício físico por semana. As médias dos motivos podem ser encontradas no gráfico 1 .

No gráfico 1 é possível verificar que a dimensão dos motivos psicológicos $(\mathrm{MED}=3,25)$ é aquela a que é dada maior relevância por parte dos 3 grupos. Já a dimensão dos motivos relacionados com o corpo $(\mathrm{MED}=0,97)$ é a dimensão que menor relevância tem nos grupos em estudo.

No gráfico 2 podemos analisar as medias de cada fator motivacional para cada grupo. Sendo assim, é verificado que os fatores revitalização, prazer e afiliação são os fatores que mais motivam as pessoas a praticar DNA. Pelo contrário, os fatores reconhecimento social, saúde e aparência, são os fatores a que os praticantes dão menos importância para a prática de DNA. 
Figura 1. Média dos Dimensões Motivacionais

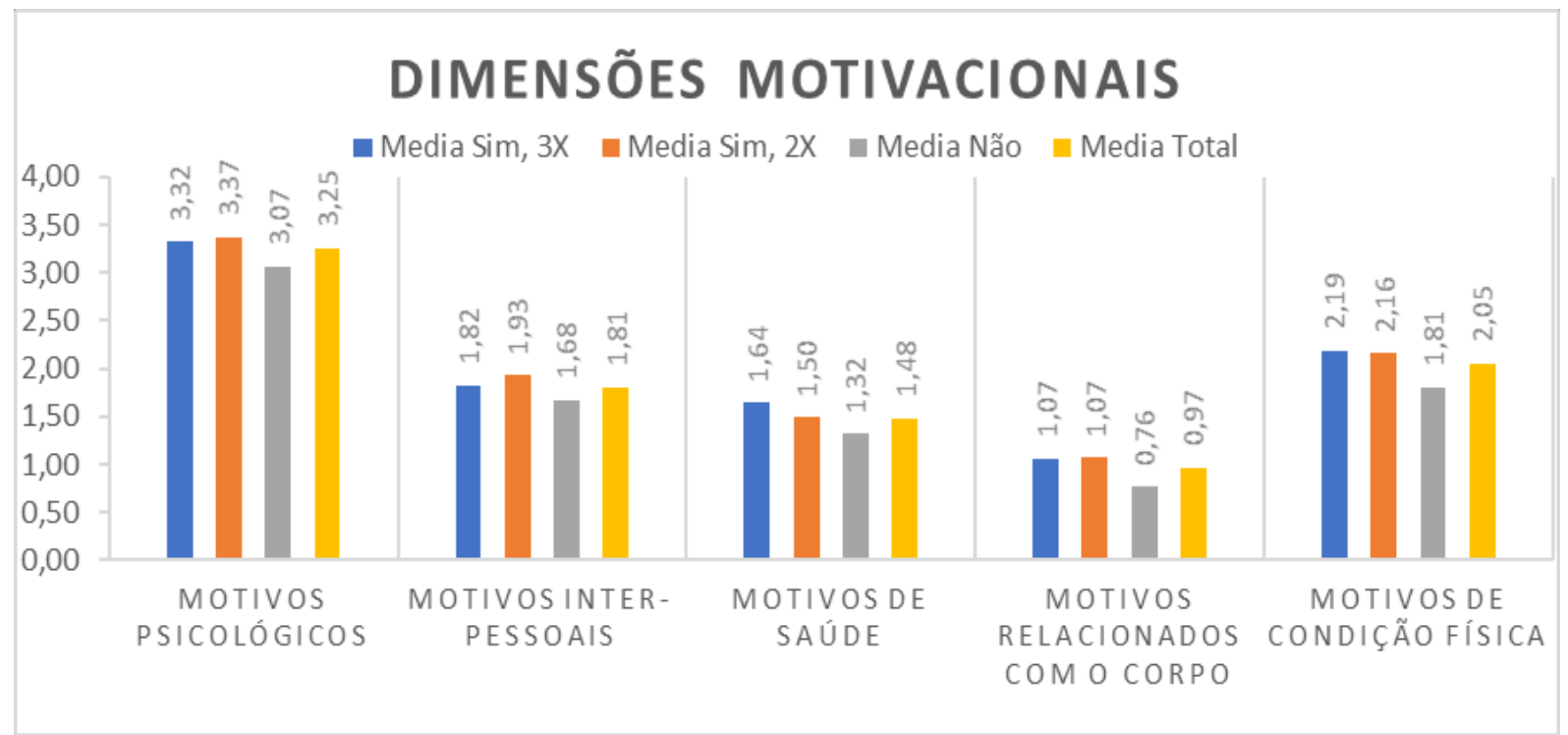

Figura 2. Média dos Fatores Motivacionais

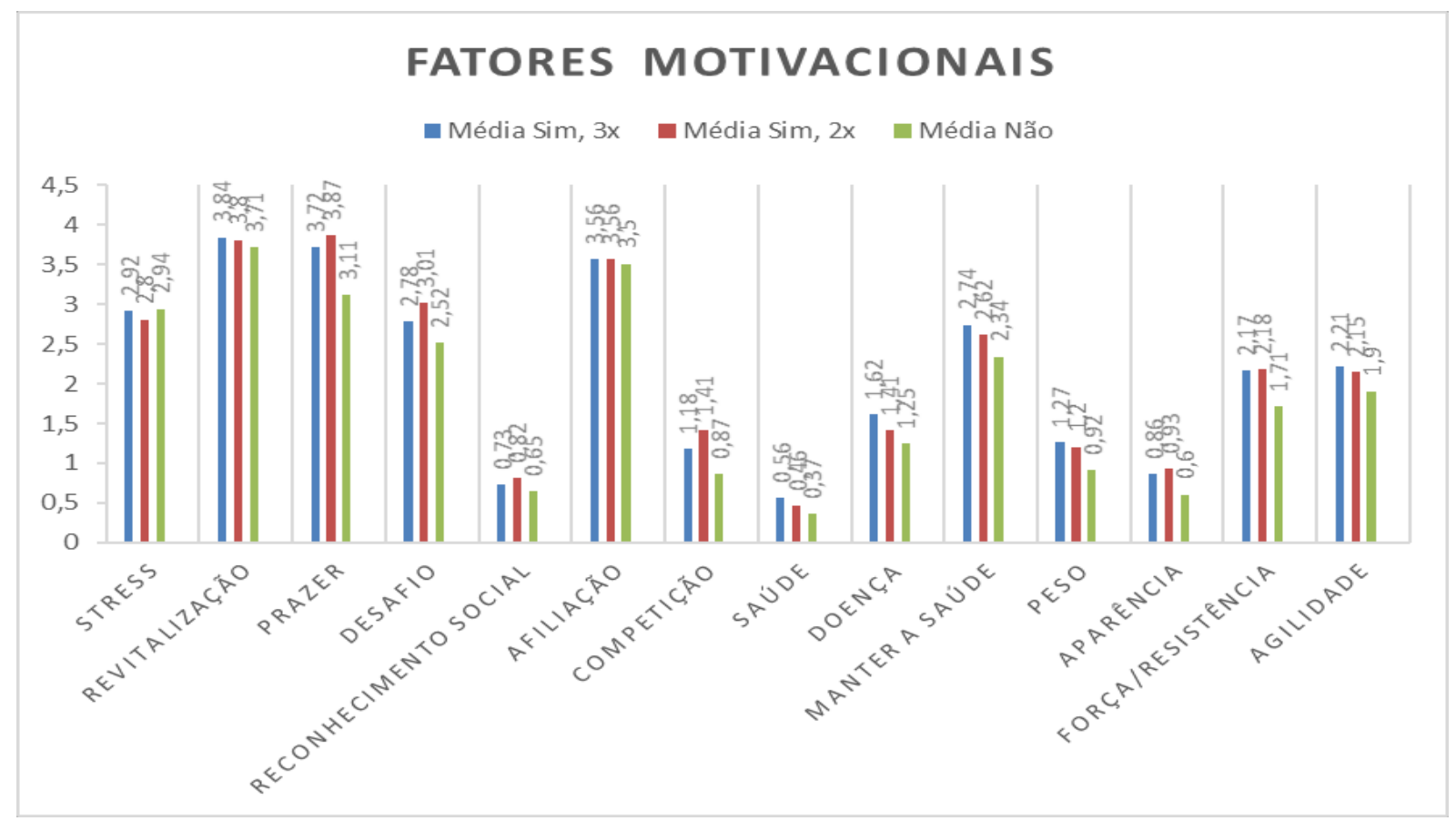


Tabela 1. Diferenças padronizadas do tamanho do efeito através do efeito de magnitude.

\begin{tabular}{|c|c|c|c|c|c|c|c|c|c|c|}
\hline \multicolumn{2}{|c|}{ Não vs. Sim, $2 x$} & Sim, $2 x$ & Não & Value & $(90 \% \mathrm{Cl})$ & $\begin{array}{c}\text { Value } \\
\text { (Magnitude) }\end{array}$ & (Magnitude) & $(90 \% \mathrm{Cl})$ & $\begin{array}{l}\text { \% greater/ } \\
\text { similar/lower }\end{array}$ & $\begin{array}{c}\text { greater/similar/l } \\
\text { ower }\end{array}$ \\
\hline & & $M \pm D P$ & $M \pm D P$ & 1 & 2 & 3 & Magnitude & 4 & 5 & \\
\hline \multirow{4}{*}{ Motivos psicológicos } & Stress & $2,80 \pm 1,42$ & $2,94 \pm 1.26$ & 1,7 & $(-7,6 ; 12,0)$ & 0,03 & Trivial & $(-0,13 ; 0,19) 0,16$ & $4 / 95 / 1$ & Likely \\
\hline & Revitalização & $3,80 \pm 1,13$ & $3,71 \pm 0,89$ & $-1,8$ & $(-7,1 ; 3,7)$ & $-0,05$ & Trivial & $(-0,21 ; 0,10) 0,15$ & $0 / 94 / 6$ & Likely \\
\hline & Prazer & $3,87 \pm 1,29$ & $3,11 \pm 1,45$ & 26,4 & $(-33,3 ; 18,7)$ & $-0,75$ & Moderado & $(-0,99 ;-0,51) 0,24$ & 0/0/100 & Almost Certain \\
\hline & Desafio & $3,01 \pm 1,34$ & $2,52 \pm 1,42$ & $-21,3$ & $(-29,4 ;-$ & $-0,47$ & Small & $(-0,68 ;-0,25) 0,21$ & $0 / 2 / 98$ & Very Likely \\
\hline \multirow{3}{*}{ Motivos Inter-pessoais } & $\begin{array}{l}\text { Reconhecimento } \\
\text { Social }\end{array}$ & $0,82 \pm 1,05$ & $0,65 \pm 0,95$ & $-5,1$ & $(-22,7 ; 16,4)$ & $-0,06$ & Trivial & $(-0,32 ; 0,19) 0,25$ & $4 / 77 / 19$ & Likely \\
\hline & Afiliação & $3,56 \pm 1,23$ & $3,50 \pm 1,11$ & $-1,2$ & $(-8,0 ; 6,1)$ & $-0,03$ & Trivial & $(-0,19 ; 0,13) 0,16$ & $1 / 95 / 4$ & Likely \\
\hline & Competição & $1,41 \pm 1,47$ & $0,87 \pm 1,18$ & $-29,4$ & $\begin{array}{r}(-42,5 ;- \\
122, \\
\end{array}$ & $-0,43$ & Small & $(-0,69 ;-0,18) 0,26$ & $0 / 7 / 93$ & Likely \\
\hline \multirow{3}{*}{ Motivos de saúde } & Saúde & $0,46 \pm 0,87$ & $0,37 \pm 0,75$ & $-9,3$ & $(-29,1 ; 15,9)$ & $-0,12$ & Trivial & $(-0,43 ; 0,19) 0,31$ & $4 / 61 / 35$ & Possibly \\
\hline & Doença & $1,41 \pm 1,48$ & $1,25 \pm 1,42$ & $-5,3$ & $(-20,6 ; 13,0)$ & $-0,07$ & Trivial & $(-0,30 ; 0,16) 0,23$ & $3 / 79 / 18$ & Likely \\
\hline & Manter a saúde & $2,62 \pm 1,72$ & $2,34 \pm 1,56$ & $-21,6$ & $\begin{array}{c}(-31,3 ;- \\
10-1\end{array}$ & $-0,38$ & Small & $(-0,59 ;-0,17) 0,21$ & $0 / 7 / 93$ & Likely \\
\hline \multirow{2}{*}{$\begin{array}{c}\text { Motivos relacionados } \\
\text { com o corpo }\end{array}$} & Peso & $1,20 \pm 1,43$ & $0,92 \pm 1,25$ & $-26,8$ & $(-40,6 ;-9,8)$ & $-0,34$ & Small & $(-0,56 ;-0,11) 0,23$ & $0 / 16 / 84$ & Likely \\
\hline & Aparência & $0,93 \pm 1,27$ & $0,60 \pm 0,98$ & -17 & $(-33,4 ; 3,4)$ & $-0,2$ & small & $(-0,43 ; 0,04) 0,23$ & $0 / 51 / 49$ & Possibly \\
\hline \multirow{2}{*}{$\begin{array}{c}\text { Motivos de condição } \\
\text { física }\end{array}$} & Força/resistência & $2,18 \pm 1,63$ & $1,71 \pm 1,41$ & -19 & $(-30,6 ;-5,4)$ & $-0,26$ & small & $(-0,45 ;-0,07) 0,19$ & $0 / 30 / 70$ & Possibly \\
\hline & Agilidade & $2,15 \pm 1,66$ & $1,90 \pm 1,49$ & $-15,7$ & $(-26,5 ;-3,4)$ & $-0,25$ & small & $(-0,44 ;-0,05) 0,20$ & $0 / 35 / 65$ & Possibly \\
\hline \multicolumn{2}{|c|}{ Não vs. Sim, $3 x$} & Sim, $3 x$ & Não & Value & $(90 \% \mathrm{Cl})$ & $\begin{array}{c}\text { Value } \\
\text { (Magnitude) }\end{array}$ & (Magnitude) & $(90 \% \mathrm{Cl})$ & $\begin{array}{c}\text { \% greater/ } \\
\text { similar/lower }\end{array}$ & $\begin{array}{c}\text { greater/similar/l } \\
\text { ower }\end{array}$ \\
\hline & & $M \pm D P$ & $\mathrm{M} \pm \mathrm{DP}$ & 1 & 2 & 3 & Magnitude & 4 & 5 & \\
\hline \multirow{4}{*}{ Motivos psicológicos } & Stress & $2,92 \pm 1,31$ & $2,94 \pm 1.26$ & 4,4 & $(-4,9 ; 14,7)$ & 0,07 & Trivial & $(-0,08 ; 0,21) 0,15$ & $7 / 93 / 0$ & Likely \\
\hline & Revitalização & $3,84 \pm 1,01$ & $3,71 \pm 0,89$ & $-2,5$ & $(-7,4 ; 2,6)$ & $-0,08$ & Trivial & $(-0,23 ; 0,08) 0,15$ & 0/91/9 & Likely \\
\hline & Prazer & $3,72 \pm 1,10$ & $3,11 \pm 1,45$ & $-20,8$ & $(-28,1 ;-12,8)$ & $-0,56$ & small & $(-0,79 ;-0,32) 0,23$ & $0 / 1 / 99$ & Almost Certain \\
\hline & Desafio & $2,78 \pm 1,29$ & $2,52 \pm 1,42$ & $-12,5$ & $(-21,5 ;-2,5)$ & $-0,23$ & small & $(-0,42 ;-0,04) 0,19$ & $0 / 39 / 61$ & Possibly \\
\hline \multirow{3}{*}{ Motivos Inter-pessoais } & $\begin{array}{l}\text { Reconhecimento } \\
\text { Social }\end{array}$ & $0,73 \pm 0,94$ & $0,65 \pm 0,95$ & $-2,6$ & $(-20,1 ; 18,8)$ & $-0,03$ & Trivial & $(-0,28 ; 0,22) 0,25$ & $6 / 80 / 14$ & Likely \\
\hline & Afiliação & $3,56 \pm 1,07$ & $3,50 \pm 1,11$ & $-1,9$ & $(-7,9 ; 4,4)$ & $-0,06$ & Trivial & $(-0,24 ; 0,13) 0,18$ & $1 / 89 / 10$ & Likely \\
\hline & Competição & $1,18 \pm 1,21$ & $0,87 \pm 1,18$ & $-16,7$ & $(-31,9 ; 1,8)$ & $-0,23$ & small & $(-0,47 ; 0,02) 0,25$ & $0 / 43 / 57$ & Possibly \\
\hline \multirow{3}{*}{ Motivos de saúde } & Saúde & $0,56 \pm 0.95$ & $0,37 \pm 0,75$ & $-12,4$ & $(-30,5 ; 10,5)$ & $-0,17$ & Trivial & $(-0,47 ; 0,13) 0,30$ & $2 / 54 / 44$ & Possibly \\
\hline & Doença & $1,62 \pm 1,53$ & $1,25 \pm 1,42$ & $-10,2$ & $(-24,2 ; 6,4)$ & $-0,14$ & Trivial & $(-0,36 ; 0,08) 0,22$ & $1 / 67 / 32$ & Possibly \\
\hline & Manter a saúde & $2,74 \pm 1,60$ & $2,34 \pm 1,56$ & $-19,8$ & $(-29,3 ;-9,0)$ & $-0,36$ & small & $(-0,56 ;-0,15) 0,20$ & $0 / 10 / 90$ & Likely \\
\hline \multirow{2}{*}{$\begin{array}{c}\text { Motivos relacionados } \\
\text { com o corpo }\end{array}$} & Peso & $1,27 \pm 1,36$ & $0,92 \pm 1,25$ & $-26,5$ & $(-39,7 ;-10,5)$ & $-0,35$ & small & $(-0,57 ;-0,12) 0,22$ & $0 / 14 / 86$ & Likely \\
\hline & Aparência & $0,86 \pm 1,12$ & $0,60 \pm 0,98$ & $-16,8$ & $(-32,2 ; 2,1)$ & $-0,22$ & small & $(-0,46 ; 0,03) 0,24$ & $0 / 45 / 55$ & Possibly \\
\hline \multirow{2}{*}{$\begin{array}{l}\text { Motivos de condição } \\
\text { física }\end{array}$} & Força/resistência & $2,17 \pm 1,46$ & $1,71 \pm 1,41$ & $-20,4$ & $(-31 ;-8,2)$ & $-0,33$ & small & $(-0,54 ;-0,12) 0,21$ & $0 / 15 / 85$ & Likely \\
\hline & Agilidade & $2,21 \pm 1,58$ & $1,90 \pm 1,49$ & $-15,8$ & $(-26,2 ;-4)$ & $-0,25$ & small & $(-0,44 ;-0,06) 0,19$ & $6 / 34 / 60$ & Possibly \\
\hline \multirow{2}{*}{\multicolumn{2}{|c|}{ Sim, $2 x$ VS. Sim, $3 x$}} & Sim, $3 x$ & Sim, $2 x$ & Value & $(90 \% \mathrm{Cl})$ & $\begin{array}{c}\text { Value } \\
\text { (Magnitude) }\end{array}$ & (Magnitude) & $(90 \% \mathrm{Cl})$ & $\begin{array}{c}\text { \% greater/ } \\
\text { similar/lower }\end{array}$ & $\begin{array}{c}\text { greater/similar/l } \\
\text { ower }\end{array}$ \\
\hline & & $M \pm D P$ & $M \pm D P$ & 1 & 2 & 3 & Magnitude & 4 & 5 & \\
\hline \multirow{4}{*}{ Motivos psicológicos } & Stress & $2,92 \pm 1,31$ & $2,80 \pm 1,42$ & 2,7 & $(-5,5 ; 11,6)$ & 0,04 & Trivial & $(-0,09 ; 0,17) 0,13$ & $2 / 98 / 0$ & Very Likely \\
\hline & Revitalização & $3,84 \pm 1,01$ & $3,80 \pm 1,13$ & $-0,7$ & $(-5,2 ; 4)$ & $-0,02$ & Trivial & $(-0,16 ; 0,12) 0,14$ & $0 / 98 / 2$ & Very Likely \\
\hline & Prazer & $3,72 \pm 1,10$ & $3,87 \pm 1,29$ & 7,6 & $(1,8 ; 13,7)$ & 0,17 & Trivial & $(0,04 ; 0,31) 0,13$ & $37 / 63 / 0$ & Possibly \\
\hline & Desafio & $2,78 \pm 1,29$ & $3,01 \pm 1,34$ & 11,2 & $(3,3 ; 19)$ & 0,18 & Trivial & $(0,06 ; 0,31) 0,13$ & $42 / 58 / 0$ & Possibly \\
\hline \multirow{3}{*}{ Motivos Inter-pessoais } & $\begin{array}{l}\text { Reconhecimento } \\
\text { Social }\end{array}$ & $0,73 \pm 0,94$ & $0,82 \pm 1,05$ & 2,7 & $(-10,8 ; 18,1)$ & 0,03 & Trivial & $(-0,14 ; 0,21) 0,18$ & $6 / 92 / 2$ & Likely \\
\hline & Afiliação & $3,56 \pm 1,07$ & $3,56 \pm 1,23$ & $-0,7$ & $(-5,9 ; 4,9)$ & $-0,02$ & Trivial & $(-0,18 ; 0,14) 0,16$ & $3 / 90 / 7$ & Likely \\
\hline & Competição & $1,18 \pm 1,21$ & $1,41 \pm 1,47$ & 18 & $(4 ; 34)$ & 0,2 & Small & $(0,05 ; 0,36) 0,16$ & $52 / 48 / 0$ & Possibly \\
\hline \multirow{3}{*}{ Motivos de saúde } & Saúde & $0,56 \pm 0.95$ & $0,46 \pm 0,87$ & $-3,4$ & $(-18,4 ; 14,4)$ & $-0,04$ & Trivial & $(-0,26 ; 0,17) 0,12$ & $3 / 85 / 12$ & Likely \\
\hline & Doença & $1,62 \pm 1,53$ & $1,41 \pm 1,48$ & $-5,2$ & $(-16,1 ; 7,2)$ & $-0,07$ & Trivial & $(-0,23 ; 0,09) 0,16$ & $0 / 91 / 9$ & Likely \\
\hline & Manter a saúde & $2,74 \pm 1,60$ & $2,62 \pm 1,72$ & 2,2 & $(-6,6 ; 11,8)$ & 0,03 & Trivial & $(-0,11 ; 0,18) 0,15$ & $3 / 97 / 0$ & Very Likely \\
\hline \multirow{2}{*}{$\begin{array}{c}\text { Motivos relacionados } \\
\text { com o corpo }\end{array}$} & Peso & $1,27 \pm 1,36$ & $1,20 \pm 1,43$ & 0,4 & $(-13,5 ; 16,6)$ & 0 & Trivial & $(-0,16 ; 0,17) 0,17$ & $3 / 95 / 2$ & Likely \\
\hline & Aparência & $0,86 \pm 1,12$ & $0,93 \pm 1,27$ & 0,3 & $(-14,6 ; 17,7)$ & 0 & Trivial & $(-0,19 ; 0,19) 0,19$ & $4 / 92 / 4$ & Likely \\
\hline \multirow{2}{*}{$\begin{array}{l}\text { Motivos de condição } \\
\text { física }\end{array}$} & Força/resistência & $2,17 \pm 1,46$ & $2,18 \pm 1,63$ & $-1,8$ & $(-11,9 ; 9,6)$ & $-0,03$ & Trivial & $(-0,18 ; 0,13) 0,16$ & $1 / 95 / 4$ & Likely \\
\hline & Agilidade & $2,21 \pm 1,58$ & $2,15 \pm 1,66$ & $-0,2$ & $(-9,8 ; 10,5)$ & 0 & Trivial & $(-0,15 ; 0,14) 0,15$ & $1 / 98 / 1$ & Very Likely \\
\hline
\end{tabular}

Na tabela 1 é possível verificar as comparações feitas entre os três grupos em estudo, nomeadamente o grupo das pessoas que não praticam exercício físico, o grupo das pessoas que praticam exercício físico até duas vezes por semana e o grupo das pessoas que praticam exercício físico pelo menos três vezes por semana. Comparando o grupo que não pratica exercício físico com o grupo que pratica exercício físico até duas vezes por semana, é possível verificar que no fator motivacional prazer existe uma diferença significativa moderada, nos fatores motivacionais de desafio, competição, manter a saúde, peso, aparência, força/resistência e agilidade encontramos uma diferença significativa small e nos fatores motivacionais de stress, revitalização, reconhecimento social, afiliação, saúde e doença não se verifica nenhuma diferença significativa sendo estas classificadas como trivial. Comparando agora o grupo que não pratica exercício físico com o grupo que pratica exercício físico pelo menos três vezes por semana, podemos verificar que os fatores motivacionais de prazer, desafio, competição, manter a saúde, peso, aparência, força/resistência e agilidade apresentam uma diferença significativa small, já os fatores motivacionais de stress, revitalização, reconhecimento social, afiliação, saúde e doença não apresentam qualquer diferença significativa. Analisando a comparação feita entre o grupo que pratica exercício físico até duas vezes por semana com o grupo que pratica exercício físico pelo menos 3 vezes por semana, é possível verificar que só o fator motivacional competição apresenta uma diferença 
significativa small sendo que os restantes fatores motivacionais não apresentam qualquer diferença significativa.

\section{Discussão}

O principal objetivo deste estudo foi identificar e comparar as principais motivações para a prática de DNA, tendo em conta a regularidade na prática de exercício físico por parte das pessoas em estudo. Além do mais, este estudo dá um contributo importante ao fazer uma identificação dos motivos entre os diferentes países.

Observando o figura 1 podemos comprovar que a dimensão dos motivos psicológicos é a dimensão que mais motiva para a prática de DNA, pois segundo (Cid et al., 2007) o exercício físico pode desencadear a sensação de vigor que conduz ao bem-estar psicológico. Este sentimento, parece que se reflete igualmente no aumento dos estados positivos de humor e numa diminuição dos níveis de depressão, ansiedade e stress.

Já no figura 2 podemos verificar que os fatores motivacionais mais marcantes para a prática de DNA são a revitalização, prazer e afiliação. A revitalização diz respeito à utilização da prática de desporto e/ou exercício físico para se sentir bem e ter uma sensação de vigor e revitalização. $O$ participante utiliza o desporto e/ou exercício físico para recarregar baterias. Já o prazer diz respeito à utilização da prática de desporto e/ou exercício físico para se divertir e obter uma sensação se gratificação. Os respondentes referem gostar da sensação e da experiência de praticar desporto e/ou exercício físico. Estes resultados parecem ser concordantes com estudos anteriores que referem estes motivos como os mais apontados pelos praticantes de DNA (Frontini et al., 2020).

Além do mais segundo Pereira (2013)e o DNA tem vindo a despertar a curiosidade e interesse de muitas pessoas, o que leva ao aumento de praticantes deste tipo de desporto. O praticante de DNA procura novas emoções e sensações, que sejam diferentes das vividas no seu dia a dia. Alguns exemplos são a conquista, o desafio e a transposição de limites, pois estes comportamentos estão ligados à motivação intrínseca, caracterizados pelo prazer e satisfação na própria atividade, segundo Brandão (2016), concordando assim com as motivações mais evidenciadas pelos praticantes, o prazer e revitalização.

A motivação intrínseca é também determinada pela satisfação das necessidades psicológicas básicas de autodeterminação ou autonomia, de competência e de pertencer ou de estar vinculado a outras pessoas. Situações que nutrem as três necessidades psicológicas promovem a motivação intrínseca, enquanto que falhas no atendimento de tais necessidades acarretam decréscimo ou até impedem seu surgimento Guimarães, Bzuneck, e Sanches
(2002). Esta definição fortalece então os dados apresentados anteriormente, que nos mostram que a afiliação também possuí grande relevância para a prática de DNA, pois a afiliação refere-se à utilização da prática de desporto e/ou exercício físico para passar tempo com amigos, fazer novas amizades e ter atividades sociais.

Hartig e Mang, (1991) e Ryan et al. (2010), enumeram que um fator determinante que desperta a vitalidade é o facto de estar ao ar livre, privilegiando o contato com a natureza. Vários estudos sugerem que o frequente contato com a natureza no nosso diaa-dia é essencial para evitar estados de stress, ansiedade e desvitalização. Para complementar esta afirmação Kaplan e Talbot (1983) e Tarrant (1996) revelam com os seus trabalhos que lembranças de vivências em contexto de ar livre são eficazes no aumento de sensações de bem-estar, em indivíduos que frequentemente estão em contextos de ar livre e em contato com a natureza. Com estas ideias, fortalece o facto dos dados por nós analisados dar enfase à revitalização e ao prazer.

$\mathrm{Na}$ tabela 1, quando comparado o grupo que não pratica exercício físico com o grupo que pratica exercício físico até duas vezes por semana é possível verificar que existe uma diferença significativa moderada no fator motivacional prazer, pois o grupo que não pratica exercício físico chega à fadiga numa forma muito mais rápida do que o grupo que pratica exercício físico até duas vezes por semana, o que leva à perda de interesse e prazer na atividade. Segundo Pereira (2009), a fadiga é um estado criado por uma atividade excessiva que deteriora o organismo e diminui a sua capacidade funcional, acompanhandose por uma sensação de doença, englobando todo o ser psíquico e físico, reduzindo a produtividade, a falta de prazer no trabalho e a diminuição do interesse pelo lazer.

Quanto às motivações menos evidenciadas estas também se ligam entre as três tabelas visto que os praticantes apontam que os parâmetros com menos evidência são a saúde, aparência e reconhecimento social. O fator motivacional da saúde diz respeito à utilização da prática de desporto ou exercício físico por aconselhamento médico, para ajudar a prevenir uma doença já presente na família ou para ajudar a recuperar de uma doença ou lesão. Esta afirmação vai ao encontro do que diz Berger e McInman (1993), comprovando então que os praticantes de DNA praticam este tipo de desporto por vontade e motivação própria e não por recomendação médica. As questões de saúde também tendem a estar mais presentes em praticantes de ginásio especialmente quando comparados com praticantes de DAS (Frontini et al., 2020). O reconhecimento social não é um fator percecionado como importante, fazendo-nos presumir desta forma que a decisão para a prática de DNA não está relacionada com reforços externos, como o desejo de vencer, ser conhecido ou ser admirado pelos outros. Esta afirmação serve então 
para fortalecer o facto de o reconhecimento social não ser muito evidenciado entre os praticantes de DNA, pois o fator motivacional reconhecimento social diz respeito à utilização da prática de desporto e/ou exercício físico para demonstrar aos outros o seu valor e ser reconhecido socialmente pelos seus feitos onde o praticante refere a importância de comparar as suas competências com as competências dos outros e para conseguir alcançar o que os outros não consegue. A necessidade deste estudo foi saber quais as motivações para a prática de DNA entre praticantes e não praticantes de exercício físico, realçando que os parâmetros mais evidenciados foram a revitalização, o prazer e a afiliação o que leva os praticantes a experimentar e a manter-se na modalidade.

$\mathrm{O}$ presente estudo apresenta algumas limitações, nomeadamente na recolha de amostra. De facto, uma parte da mesma foi recolhida através de redes sociais não garantindo a representatividade da amostra e a generalização dos resultados. No entanto, uma forma de colmatar essa falha foi procurar recolher o resto da amostra presencialmente em diferentes ginásios e federações/clubes de várias zonas do país. Outra limitação prende-se com o facto de este ser um estudo transversal, não permitindo inferências de causalidade. De facto, não é

possível compreender se estes motivos estão na base da escolha da prática da modalidade ou se foi a própria prática que fez com que os respondentes se interessassem mais por determinada questão. Apesar destas limitações, o presente estudo representa um contributo

importante para a investigação e a prática nesta área, colmatando importantes limitações na literatura e lançando ideias para investigações futuras.

\section{Conclusão}

Com este trabalho concluímos que os praticantes de DNA, tanto praticantes como não praticantes de exercício físico, praticam este grupo de modalidades para sentir emoções de revitalização, prazer e afiliação, dando pouca importância às dimensões das pressões de saúde, aparência e reconhecimento social. Os praticantes de DNA indicaram que procuram neste grupo de modalidades as motivações relacionadas com o prazer, a revitalização e a afiliação, para se sentirem bem consigo próprias e deixar de lado o stress do quotidiano.

Podemos assim levantar a possibilidade de um dos fatores determinantes para a revitalização, o prazer e afiliação ser o tempo que estes praticantes passam ao ar livre, tendo o privilégio de estar em contacto com a natureza e o convívio com outras pessoas.

Vemos este estudo como algo para melhorar o conhecimento na área da motivação para a prática do exercício físico no DNA. Uma das nossas preocupações reveste-se com o aumento da performance das pessoas que praticam DNA de forma recreativa. Assim, acreditamos que compreendendo melhor as suas motivações conseguiremos adaptar a sua prática e, consequentemente, melhorar a performance. Outras investigações do género devem ser feitas para fornecer uma análise mais detalhada sobre os motivos para a prática do DNA, a nível do sexo, do género, assim como para as várias modalidades desportivas do DNA.

\section{Referências}

Alves, J., \& Lourenço, A. (2003). Tradução e adaptação do questionário de motivação para o exercício. Desporto, Investigação e Ciência, 2, 323

Berger, B. G., \& McInman, A. (1993). Handbook of research on sport psychology. In, R. Singer, M. Murphey, \& T. L. K. (Eds.), Exercise and the quality of life. (pp. 729-760). New York: Macmillan.

Brandão, A., Frontini, R., Peixoto, D., Fernandes, D., \& Clemente, F. (2020). Comparación de factores motivacionales entre la práctica de deportes de naturaleza, aventura competitiva y ocio. SPORT TK-Revista EuroAmericana de Ciencias Del Deporte, 9(1), 15-20. https://doi.org/10.6018/sportk.413241

Brandão, A., Peixoto, D., Frontini, R., Fernandes, D., \& Clemente, F. (2019). Motivation between trekking and Trail Running. Motricidade, 15(S1), 215 .

Brandão, A., Sarmento, D., Frontini, R., Fernandes, D., \& Clemente, F. (2018). Comparação de fatores motivacionais entre a prática do desporto de natureza e aventura competitiva e de lazer. Livro de Atas Do $2^{\circ}$ Fórum REDESPP Desporto, November, 93-94.

Brandão, A. (2016). Perceção do risco e segurança no Canyoning, a experiência e confiança necessária para a prática da modalidade. Universidade de Trás-os-Montes e Alto Douro. https://repositorio.utad.pt/bitstream/10348/6635/ 1/phd ajmjbrandão\%0Ahttps://repositorio.utad.p t/bitstream/10348/6635/1/phd_ajmjbrandão.pdfB uckley R. (2012). Rush as a key motivation in skilled adventure tourism: Resolving the risk recreation paradox. Tour Manag, 33(4), 961-970.

Carneiro, D. (2011). Prescrição de exercício físico: A sua inclusão na consulta. Revista Portuguesa de Clínica Geral, 27(5), 470-479. https://doi.org/10.32385/rpmgf.v27i5.10890

Chazaud P. (2004). Management du tourisme et des loisirs sportifs de pleine nature. Presses Universitaires du Sport.

Cid, L., Silva, C., \& Alves, J. (2007). Actividade física e bem-estar psicológico: Perfil dos participantes no programa de exercício e saúde de 
rio maior. Motricidade, 3(2). https://doi.org/10.6063/motricidade.3(2).674

Frontini, R., Brandão, A., Monteiro, M., Salvador, R., Lima, R., Fernandes, D., \& Clemente, F. M. (2019). Comparison of motivational factors for the practice of exercise at gyms and nature and adventure sports. Journal of Human Sport and Exercise, 14, (4proc), S1189-S1192. https://doi.org/10.14198/jhse.2019.14.Proc4.82

Frontini, R., Brandão, A., Salvador, R., Lima, R., Monteiro, M., Fernandes, D., \& Clemente, F. M. (2020). O que motiva a prática de exercício físico em ginásios e a prática de desportos de natureza e aventura? Um estudo comparativo. In Atividade Física, Lazer e Saúde - Perspetivas e Desafios de Investigação (pp.54-64). Instituto Politécnico de Castelo Branco.

Frontini, R., Monteiro, M., Brandão, A., \& Clemente, F. M. (2018). Análise exploratória da associação entre motivos para a prática do exercício físico e composição corporal. BMC Health Services Research 2018, 18(Suppl 2), 684. https://doi.org/doi.org/10.1186/s12913-018-

3444-8

Guimarães, S. É., Bzuneck, J. A., \& Sanches, S. F. (2002). Psicologia educacional nos cursos de licenciatura: A motivação dos estudantes. Psicologia Escolar e Educacional, 6(1), 11-19. https://doi.org/10.1590/s141385572002000100002

Hartig, T., \& Mang, M. (1991). Restorative effects of natural environment experiences. Environment and Behavior, 23(1), 3-26. https://doi.org/10.1177/0013916591231001Kapl an, S., \& Talbot, J. F. (1983). Psychological benefits of a wilderness experience. In Plenmun Press (Ed,) Behavior and the Natural Environment (pp.163-203). https://doi.org/10.1007/978-1-4613-3539-9_6

Markland, D., \& Ingledew, D. K. (1997). The measurement of exercise motives: Factorial validity and invariance across gender of a revised Exercise Motivations Inventory David. British Journal of Health Psychology, 2, 361-376.

Moutão, J. (2005). Motivação para a prática de exercício físico: Estudo dos motivos para a prática de actividades de fitness em ginásios. Universidade de Trás-os-Mones e Alto Douro.

Pereira, C. (2009). Efeitos de um programa de ginástica laboral sobre as principais sintomatologias das lesões por esforço repetitivo/ distúrbios osteomusculares relacionados ao trabalho (Ler/Dort): Dor E Fadiga. Universidade de Brasília.

Pereira, J. (2013). Desporto e lazer. A segurança em desportos de natureza e aventura. Instituto
Politécnico de Viana do Castelo.

Potteiger, J. (2017). ACSM's introduction to exercise science: Second edition. (Second Edition). Wolters Kluwer Health Adis (ESP).

Ryan, R. M., Weinstein, N., Bernstein, J., Brown, K. W., Mistretta, L., \& Gagné, M. (2010). Vitalizing effects of being outdoors and in nature. Journal of Environmental Psychology, 30(2), 159-168. https://doi.org/10.1016/j.jenvp.2009.10.009

Tarrant, M. A. (1996). Attending to past outdoor recreation experiences: Symptom reporting and changes in affect. Journal of Leisure Research, 28(1), 1-17.

https://doi.org/10.1080/00222216.1996.1194977 


\title{
Caracterização do Turista de Levadas, Veredas e Btt no Parque Natural da Madeira
}

\author{
João Prudente ${ }^{1,2}$, Helder Lopes ${ }^{1,2}$, João Noite ${ }^{1,2}$, Ana Rodrigues ${ }^{1,2}$, Ricardo \\ Alves $^{1,2}$, Catarina Fernando ${ }^{1,2}$
}

${ }^{1}$ Universidade da Madeira (UMA)

${ }^{2}$ Centro de Investigação, Desenvolvimento e Inovação em Turismo (CITUR)

Palavras-chave
Turismo Ativo;
Desporto de
natureza;
Caminhadas;
BTT.

Keywords Active Tourism; Nature Sport; Hiking; Mountain Bike.

\begin{abstract}
RESUMO:
Este estudo caracteriza o turista que realiza atividades em Bicicleta Todo o Terreno (BTT) e caminhadas nas Levadas (G1) e Veredas (G2) no Parque Natural da Madeira. Participaram, através de questionário, 449 praticantes, de 21 nacionalidades. Caracterizada a amostra (média, desvio padrão e percentagem), aferiu-se a associação entre variáveis (Qui-Quadrado) e testouse as diferenças entre os grupos (Anova a um fator) em função da atividade praticada (Post Hoc,

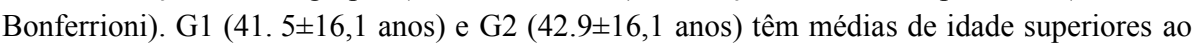
BTT $(36.73 \pm 9,0$ anos); mais mulheres no G2 $(58 \%)$ e G1 $(56.8 \%)$, mais homens no BTT (92.2\%); maioritariamente turistas estrangeiros (G1-73.4\%; G2-82.3\% e BTT-96.1\%). Os inquiridos, maioritariamente ativos (entre $67.5 \%$ a $89.5 \%$ ), com formação superior $(54.1 \%$ ), realizam atividade física regular $(86.4 \%)$, dos quais $(80.6 \%)$ realiza no mínimo trinta minutos de atividade física diária. O grupo do BTT pratica atividade física organizada (98\%), apresentando menor fator de risco (3.9\%) (U.S.D.H.H.S., 2018) e valores superiores de atividade física semanal ( $8.6 \pm 4.9$ horas), relativamente a G1 e G2. Estes dados permitirão adequar a oferta aos diferentes grupos de turistas e elaborar normas de segurança. É necessário aprofundar o estudo, alargando a amostra e o número de percursos em Levadas, veredas e BTT.
\end{abstract}

\section{ABSTRACT:}

This study characterizes the tourist who performs Mountain Bike (BTT) activities and walks in Levadas (G1) and Veredas (G2) in Madeira Natural Park. Through a survey, we collected 449 surveys from participants from 21 different nationalities. The sample was characterized (mean, standard deviation and percentage), the association between variables was tested (Chi-Square) and the differences between groups (Anova to one factor) according to the practiced activity (Post Hoc, Bonferrioni). G1 (41.5 \pm 16.1 years) and G2 (42.9 \pm 16.1 years) present a higher average age than BTT $(36.73 \pm 9.0$ years); more women participated in G2 $(58 \%)$ and G1 (56.8\%) activities and more men in BTT $(92.2 \%)$; the sample is mostly composed by foreign tourists (G1-73.4\%; G2-82.3\% and BTT-96.1\%). In general, the sample is mostly active (between $67.5 \%$ to $89.5 \%$ ), with higher education $(54.1 \%$ ) and performs regular physical activity (86.4\%). $80.6 \%$ performs at least thirty minutes of daily physical activity. BTT practitioners are more involved in organized physical activity (98\%), presenting a lower risk factor $(3.9 \%)$ (USDHHS, 2018) and higher values of weekly physical activity (8.6 \pm 4.9 hours), compared to G1 and G2. These data will allow address the offer to specific groups of tourists and to develop safety standards. It is necessary to deepen the study, expanding the sample and the number of routes in Levadas, paths and BTT. 


\section{Caracterização do turista de Levadas, Veredas e Btt no Parque Natural da Madeira}

O turismo na Ilha da Madeira destaca-se pelos seus festivais de cor e música como a Festa da Flor, o Festival do Atlântico, o Fim do Ano e o Carnaval. Todos estes eventos foram alvo de investigação na última década permitindo compreender, entre outras coisas, o perfil do turista, a duração das estadias ou os níveis de satisfação (Almeida, Teixeira \& Franco, 2019; Marujo, 2014; Marujo, 2013; ISMERI Europa, 2011).

Será importante também referir que outros estudos se têm concentrado noutras áreas como a evolução histórica e desafios do Turismo na Madeira (Almeida, 2016; Baptista, 2005; Faria, Tiago, Tiago \& Couto, 2014; ISMERI, 2011). Uma pesquisa nos diversos meios de publicação de investigação científica permite o encontro de trabalhos na área da economia e turismo, no impacto que a atividade tem na população e também alternativas de exploração turística (Almeida \& Correia, 2010; Barros, 2007; Cho, 2010; Machado, Santos \& Sarmento, 2009; Oliveira \& Pereira, 2008; RAM, 2016; Valls, Mota, Vieira \& Santos, 2019).

Contudo, sabe-se que a popularidade do turismo em espaços naturais, com recurso a atividades recreativas, está em forte desenvolvimento, em especial na Europa. A Ilha da Madeira com a sua natureza e paisagens exuberantes não é exceção a esta tendência, mas a caracterização do perfil do turista nas suas principais atrações, Levadas e Veredas, tem sido feita de forma deficitária (Franco Roque, Nogueira Mendes, Magalhães \& Silva, 2018; Nogueira Mendes et. al, 2012).

Assim, o objetivo deste estudo é caracterizar o perfil do turista que se envolve nas atividades de recriação nos espaços naturais da Ilha da Madeira, com especial atenção para as caminhadas em Levada dentro da Floresta Laurissilva, as caminhadas por Veredas fora da Floresta Laurissilva e atividades com bicicleta todo-o-terreno nas serras do Parque Natural da Madeira.

A importância do turismo à escala mundial é inegável e é um fator crítico para o crescimento económico de zonas periféricas, rurais e insulares que apresentam dificuldades no desenvolvimento industrial tradicional e que têm de se apoiar nos seus recursos naturais e históricos para gerarem uma economia saudável (Fernandes, 2015).

A Madeira, sendo uma zona periférica de Portugal e da Europa, assenta grande parte da sua atividade económica no Turismo, tirando partido do seu clima ameno ao longo de todo o ano, beleza natural paisagística e festivais de beleza, cor e luz (Almeida, 2016; Almeida \& Correia, 2010; Barros, 2007; Machado, 2011).

Contudo, de acordo com o Plano de Ordenamento Turístico da RAM, as Levadas e Veredas que ladeiam montanhas e encostas desta região são um produto turístico em crescimento que tem o seu público alvo que são os aficionados pelo turismo de natureza, ecoturismo, turismo de desporto na natureza e turismo aventura que procuram novas formas de conhecer um determinado destino turístico (Almeida, 2010; Fernandes, 2015; Fernandes, 2012; Fernandes, 2011; Kastenholz \& Rodrigues, 2007; Oliveira \& Pereira, 2008; Rodrigues \& Virtudes, 2019). Este crescimento é uma tendência que se verifica na Madeira e noutros pontos do globo, com especial enfoque no Continente Europeu que sempre teve uma procura mais forte pelos seus locais históricos em relação às atividades nos espaços e parques naturais (Franco Roque et. al 2018; Gómez-Martín, 2019).

$\mathrm{O}$ turismo de natureza, onde se incluem as atividades desporto de natureza, é um dos dez produtos definidos no Plano Estratégico Nacional do Turismo (PENT), produtos selecionados em função das quotas de mercado, potencial de crescimento, bem como da aptidão e potencial competitivo de Portugal, nos quais deverão assentar as políticas de desenvolvimento e capacitação da nossa oferta turística e onde as ilhas dos Açores e da Madeira, devido às suas características especiais de natureza geológica e de biodiversidade, constituem um cenário de excelência para o desenvolvimento do Turismo da Natureza. (Turismo de Portugal, 2006).

De acordo com Melo e Gomes (2017), pode-se caracterizar o turista de desporto na natureza como: sendo maioritariamente homens, com formação superior, que trabalha por conta de outrem, mas em trabalhos qualificados e que aufere salário acima da média.

Podemos ainda dividir o turista de natureza em duas categorias: o "Consumidor de Natureza soft" e o "Consumidor de Natureza hard" (Turismo de Portugal, 2006).

No caso do "Consumidor de Natureza soft" o turista viaja em família, sendo constituído por uma população com uma média de idades mais elevada, em fase de aposentadoria, com filhos. Este grupo aponta como principais motivações o "descansar e desligar no meio natural; caminhar e descobrir novas paisagens; fotografia; e visitar atrativos interessantes" (Turismo de Portugal, 2006).

Já o "Consumidor de Natureza hard" é mais jovem, com idades entre os 25 e os 30 anos, estudantes ou pertencentes a profissões liberais e praticantes de desportos ou atividades de interesse especial. Participam no turismo de natureza com o intuito de praticar desportos de interesse especial, aprofundar o conhecimento da Natureza e para aquisição de educação ambiental (Turismo de Portugal, 2006).

As Levadas são sistemas de irrigação feitas pelo homem, muitas vezes esculpidas nas rochas das montanhas, que transportam água de um ponto para outro, percorrendo por vezes longas distâncias em cenários de beleza natural únicos (Almeida, 2010; Fernandes, 2016). As suas passagens estreitas, oferecem uma oportunidade única para caminhar por 
zonas esculpidas por vulcões ladeadas pela vegetação exuberante e abundante da Floresta Laurissilva (Velvet, 2015). Aos dias de hoje, apesar de manterem a sua função, são também amplamente utilizadas por turistas que procuram visitar a paisagem mais selvagem da Ilha da Madeira.

Estas Levadas apresentam diferentes níveis de dificuldade, quer seja pelo declive, distância/duração ou tipo de terreno. Estas informações são devidamente assinaladas nos placares à entrada das Levadas e pelos operadores turísticos. No entanto, muitos turistas optam por fazer estas caminhadas sem recurso a um guia credenciado (Oliveira \& Pereira, 2008; Velvet, 2015).

Já as Veredas são percursos pedonais, muitas vezes de interesse turístico (Decreto Legislativo Regional n.o7-B/2000/M), que podem estar em áreas do Parque Natural, em terrenos públicos, privados ou ambos (Fernandes, 2015; Fernandes, 2012; Fernandes, 2011).

Muitos destes percursos correspondem às vias de acesso entre pontos de interesse, criados por gerações anteriores e que hoje são maioritariamente utilizados por quem visita a Região Autónoma da Madeira.

A bibliografia que aborda especificamente as Veredas é escassa, sendo mais comum encontrar documentação que aborda Veredas e Levadas como um objeto único, quando são elementos completamente distintos.

Em 2000 foi criado um diploma regional que recomenda vários percursos pedonais que englobam Veredas e Levadas.

As atividades em bicicletas todo o terreno, ou BTT, têm o seu princípio nos anos oitenta, tendo crescido até se transformar no fenómeno global que conhecemos hoje em dia (Kelly, 2014; Reis, Lovelock, \& Jellum, 2014). Esta evolução levou a que, na atualidade, muitos turistas viagem pelo mundo e conheçam os seus destinos através da realização desta atividade, que apresentam percursos preparados para o efeito pelas suas paisagens mais icónicas (Courtney, 2018; Reis et al.,2014).

Os percursos em BTT com fim turístico apresentam uma superfície de terreno dura e normalmente longos corredores, podendo variar na sua forma e comprimento (Reis et al., 2014). Os mesmos percursos são utilizados para outras atividades como jogging, hiking e passeios a cavalo, por exemplo (Reis \& Jellum, 2012).

$\mathrm{O}$ rápido crescimento desta atividade em espaços naturais, com propósito turístico, deve-se ao disfrutar estético que uma experiência deste género pode proporcionar. O seu valor maior está relacionado com a proximidade à paisagem visitada e respetiva flora $\mathrm{e}$ fauna, com o nível de dificuldade, com a sensação de desafio e com a beleza cénica que se pode obter nos trilhos (Moran, Tresidder, \& McVittie, 2006).

Assim sendo, as estratégias turísticas baseadas no ciclismo são, nos dias de hoje, frequentemente utlizadas como meio de diversificação da oferta turística, especialmente em zonas não urbanas, mas nas zonas com terrenos desafiantes e de beleza paisagística (Buning \& Lamont, 2020; Reis \& Jellum, 2012).

O Governo Regional introduziu legislação já em 2008, abrindo espaço à criação deste modelo de negócio inovador para a Ilha, o que incentivou a criação de novas empresas e exploração de novas atrações turísticas que se destacam como excelentes objetos de estudo.

Atualmente a Madeira é um destino Europeu popular que recebe perto de 1000000 de visitantes por ano (Secretaria Regional da Cultura, Turismo e Transportes, 2013). Contudo, foi descrita como aborrecida, onde a média de idades dos turistas é alta e onde há falta de aventuras, num estudo publicado por McQuilkin em 2013.

Dado o impacto que o turismo tem na atividade económica da região e dada a diversificação da oferta que se tem verificado nas últimas décadas (Barros \& Machado, 2010) com o surgimento das empresas que oferecem aventuras como BTT, o objetivo deste estudo é caracterizar o perfil do turista que visita a Ilha da Madeira para três atividades - Levadas, Veredas e BTT. Secundariamente, iremos comparar com a bibliografia que caracteriza o turista da Festa da Flor, do Festival do Atlântico, do Fim do Ano e do Carnaval, tendo em conta os dados recolhidos pelo Observatório de Turismo da Madeira.

\section{Método e Procedimentos}

O trabalho apresentado assenta na aplicação de um questionário adaptado de Florido (2010) aos turistas. Foram definidos três cenários diferentes, todos situados na área do Parque Natural da Madeira:

G1, Levadas - percursos realizados ao longo dos canais de água e no interior da mancha florestal da Laurissilva;

G2, Veredas - percursos realizados em percursos de montanha, em terrenos fora da mancha florestal, áridos e pedregosos;

BTT - em percursos demarcados para a prática do BTT, situados em zona de montanha, mas fora da zona de Floresta Laurissilva.

Foram obtidas 449 respostas válidas, tendo os participantes sido inquiridos logo após o final da atividade e no próprio local ou após a chegada ao Hotel, respondendo através do endereço eletrónico do inquérito que lhes foi fornecido e na língua materna, ou de preferência, de cada um dos turistas, no caso de não estar disponível o inquérito online na língua de origem.

\section{Participantes}

Nesta investigação foi utilizada uma amostra de conveniência constituída por 449 turistas, de ambos os sexos (217 homens e 232 mulheres), com uma média de idades de $41.5 \pm 16.1$ anos, que realizaram uma das seguintes atividades: G1 - Levada $(\mathrm{n}=222)$; 
G2 - Vereda $(\mathrm{n}=176)$ e BTT - Bicicleta todo o terreno $(\mathrm{n}=51)$.

Para garantir a aleatoriedade da amostra foram seguidos os seguintes passos: no final da atividade eram entregues sete questionários às pessoas que chegavam ao ponto de repouso final, de maneira consecutiva; foi entregue um questionário por cada participante que quisesse colaborar; só após todos os sete questionários serem devolvidos à equipa de investigadores e depois dos inquiridos terem abandonado o local de recolha é que se procedia à entrega de sete novos questionários. Este procedimento decorria por seis horas.

Recolheram-se sensivelmente cinquenta questionários por dia (dia $1=51$; dia $2=54$; dia $3=48$; dia $4=57$; dia $5=54$; dia $6=51$; dia $7=54$;) sendo que vinte e nove foram recolhidos on-line e os 51 elementos do "BTT" colaboraram em 5 dias diferentes, dada a especificidade da atividade (dia $1=7$; dia $2=18$; dia $3=6$; dia $4=7$; dia $5=13$ ).

\section{Instrumento}

Como instrumento para a recolha de informação recorreu-se ao questionário de Florido (2010) designado por "Cuestionario sobre experiências flow en espácios naturales (CEFEN)". Atendendo a nacionalidade da maioria dos turistas que visitam a ilha da Madeira (Direção Regional de Estatística da Madeira, 2018), recorreu-se ao questionário na sua língua original (espanhol) e procedeu-se ao desenvolvimento da tradução para a língua alemã, inglesa, portuguesa, francesa e polaca.

Numa primeira fase, procedeu-se à tradução do instrumento por nativos nas diferentes línguas e com domínio da língua portuguesa. Cada tradução, foi posteriormente alvo de discussão em equipa, constituída pelo elemento que elaborou a tradução, especialista no domínio da língua, e especialistas das ciências do desporto, sendo a versão final obtida por debate e consenso entre os elementos da equipa. Posteriormente foi realizada nova tradução do questionário nas diferentes línguas, para a língua original (espanhol) e confrontadas as versões de modo a identificar possíveis divergências, sendo estas situações alvo de correção.

Posteriormente, realizou-se um estudo piloto em que o questionário foi aplicado nas diversas línguas a um grupo de turistas, com o intuito de testar os procedimentos protocolares, bem como identificar questões dúbias que necessitavam de ajustamento. Foi apenas identificado um termo dúbio na versão em inglês do questionário, que foi prontamente corrigido. Nada mais foi detetado, considerando-se o questionário em condições de ser aplicado, resultando deste modo a versão final do questionário.

Deste modo, a versão final do questionário é constituída por duas secções: (i) perfil dos turistas (género, profissão, condição profissional, residência, nacionalidade, habilitações académicas, prática de atividade física, atividade realizada) e

Caracterização da experiência flow.

O presente estudo centrou-se na seção i.

\section{Procedimentos}

Uma equipa de sete investigadores, pertencentes à Universidade da Madeira, recolheu entre julho de 2019 e janeiro de 2020 os questionários. Esta equipa não tinha qualquer tipo de relação prévia com os sujeitos que pertencem à amostra.

A larga maioria dos questionários (420) foi recolhida no local da atividade, após o seu término.

Os restantes questionários foram obtidos através do seu preenchimento on-line. Para o efeito, aos turistas que não podiam colaborar no fim das atividades, mas que demostravam interesse em participar, era entregue um $Q R$ code e um link direto que os direcionava para uma página internet Google Forms onde se apresentava o questionário.

A aleatoriedade da amostra foi garantida da seguinte forma: na zona de repouso onde se concluía a atividade, entregaram-se consecutivamente sete questionários às pessoas que chegavam; um por cada participante que quisesse colaborar; só quando os sete questionários eram devolvidos aos investigadores e só depois dos inquiridos terem deixado a zona de repouso é que avançava para nova recolha de mais sete questionários.

Por vezes um só grupo de pessoas esgotava os sete questionários e noutros momentos eram envolvidas pessoas de grupos diferentes.

Nas Levadas dentro da Floresta Laurissilva e nas Veredas fora da Floresta Laurissilva obtinham-se entre cinquenta a sessenta questionários por dia, em seis horas de recolha (dia: $1=51 ; 2=54 ; 3=48 ; 4=57$; $5=54 ; 6=51 ; 7=54 ;$ ). Já para o BTT, devido aos constrangimentos próprios da atividade, a recolha diária era inferior (dia: $1=7 ; 2=18 ; 3=6 ; 4=7 ; 5=13$ ) sendo necessários cinco dias para obter 51 questionários.

Os locais de recolha dividiram-se por três Levadas, duas Veredas e um percurso de BTT, todos em espaço do Parque Natural e os percursos onde se recolheu a amostra foram os seguintes:

a) Levada dos Balcões - duração: 1h30; distancia: $1,5 \mathrm{~km}$; Maior Altitude: $880 \mathrm{~m}$; Menor Altitude: 870m; Dificuldade: A1 (Plano); Perigosidade: B1 (Toda a família); Obstáculos: n/a; Avaliação Global: D1 (Fácil).

b) Levada das 25 fontes - duração: 3h30; distância: 8,6 km; Maior Altitude: 1290m; Menor: Altitude 950m; Dificuldade: A2 (Ondulado); Perigosidade: B1 (Toda a família); Obstáculos: C2 (Vertigens); Avaliação Global: D2 (Moderado).

c) Levada das Queimadas - duração: 6h30; distancia: 8,7 km; Maior Altitude: 1020m; Menor: Altitude 872m; Dificuldade: A2 (Ondulado); Categoria: B1 (Toda a família); 
Obstáculos: $\quad \mathrm{C} 1 / \mathrm{C} 2 \quad$ (Túnel/Vertigens); Avaliação: Global D2 (Moderado).

d) Vereda do Pico do Areeiro - duração: 3h30; distancia: $7 \mathrm{~km}$; Maior Altitude: 1857m; Menor Altitude: $1491 \mathrm{~m}$; Dificuldade: A3 (Acidentado); Categoria: B1 (Adultos); Avaliação Global: D2 (Difícil).

e) Vereda da Ponta de São Lourenço - duração: 2h30; distancia: 3km; Maior Altitude: 126m; Menor Altitude: 27m; Dificuldade: A2 (Ondulado); Categoria: B1 (Toda a família); Dificuldade: A3 (Acidentado); Avaliação Global: D2 (Moderado).

f) BTT - Percurso: Poço da Neve - Pico Alto (zona do Poiso); Duração: 15-25 minutos; Dificuldade: praticantes com algum nível de experiência; Declive: Por vezes bastante acentuado; Largura do corredor - Por vezes inferior a 1 metro.

\section{Análise Estatística}

Inicialmente foi feita uma análise exploratória dos dados, pretendia-se identificar possíveis erros de entrada de dados e avaliar a distribuição das variáveis quantitativas. Utilizou-se a média, o desvio padrão e a percentagem para caracterizar a amostra nas variáveis em estudo.

Foi utilizado o teste Qui-Quadrado para aferir a associação entre variáveis qualitativas, nominais e ordinais. Para testar diferenças entre os 3 grupos de atividades, em variáveis qualitativas com uma distribuição normal recorreu-se a Anova a um fator, com Post Hoc através do teste de Bonferrioni, em função da atividade praticada (G1, G2 e G3).

Foi através do software SPSS, na sua versão 26.0, que se desenvolveu todo o tratamento estatístico.

O nível de significância adotado foi de 5\%.

\section{Resultados}

A caracterização do perfil dos turistas baseou-se em indicadores demográficos, socioeconómicos e perfil de atividade física, de uma forma global e por atividade realizada na sua visita à Madeira.

\section{Perfil Demográfico}

Considerando as características demográficas idade e género, verificam-se diferenças entre os praticantes das três atividades $(\mathrm{p}<0,05)$, sendo que os praticantes da atividade de BTT caracterizam-se por ser, em média, mais novos e em maior proporção do género masculino comparativamente às Veredas e às "Levadas" (Tabela 1).

Sensivelmente um em cada cinco turistas reside em Portugal (22.1\%), seguindo-se os turistas que reportam residir na Alemanha $(19.2 \%)$, França $(13.6 \%)$ e Espanha $(8.7 \%)$. No entanto, é evidente a diversidade de países de origem, sendo reportados vinte e um países distintos. Verificando-se que os turistas residentes em Portugal, optam em menor proporção pela atividade de BTT comparativamente aos não residentes $\left(Q_{u i}{ }^{2}=12.389 ; p=0,002\right)(p<0,05)$.

Tabela 1. Perfil demográfico e residência dos visitantes.

\begin{tabular}{lccccc}
\hline Características & $\begin{array}{c}\text { Total } \\
(\mathbf{n = 4 9 9})\end{array}$ & $\begin{array}{c}\text { Levadas } \\
(\mathbf{n = 2 2 2})\end{array}$ & $\begin{array}{c}\text { Veredas } \\
(\mathbf{n = 1 7 6})\end{array}$ & $\begin{array}{c}\text { BTT } \\
(\mathbf{n = 5 1})\end{array}$ & $\boldsymbol{p}$ \\
\hline Idade (anos) & $41.5 \pm 16,0$ & $41.5 \pm 16.1$ & $42.9 \pm 17.2$ & $36.73 \pm 9.0$ & 0,020 \\
Género (\%) & & & & & \\
$\quad$ Homens & $48.3 \%$ & $43.2 \%$ & $42.0 \%$ & $92.2 \%$ & $<0,001$ \\
$\quad \begin{array}{c}\text { Mulheres } \\
\text { Residência }\end{array}$ & $51.7 \%$ & $56.8 \%$ & $58.0 \%$ & $7.8 \%$ & \\
$\quad \begin{array}{c}\text { Portugal } \\
\text { Outra }\end{array}$ & $22.1 \%$ & $26.6 \%$ & $21.7 \%$ & $3.9 \%$ & 0,002 \\
\hline
\end{tabular}

\section{Dados Socioeconómicos}

A maioria dos participantes possui como habilitações académicas o ensino superior $(54.1 \%)$ e encontramse ativos profissionalmente (72.3\%). Considerando a atividade desenvolvida, constata-se que os participantes da atividade de caminhadas são em maior proporção possuidores de habilitação académica mais baixa e os da atividade do BTT são, em proporção, os mais ativos profisssionalmente $(\mathrm{p}<0,05)$ (Tabela 2).

\section{Perfil de Atividade Física}

A maioria dos participantes reporta realizar uma atividade física regularmente $(86.4 \%)$, sendo que quatro em cada cinco afirma realizar no mínimo trinta minutos de atividade física por dia $(80,6 \%)$. Em média, os turistas inquiridos reportam realizar aproximadamente sete horas de atividade física semanalmente, no entanto, é evidente a variabilidade de comportamentos pelo elevado desvio padrão. Os participantes na atividade de BTT, reportam um perfil de atividade física mais ativo, reportando maior taxa de participação em atividade física organizada (98\%), menor prevalência de fator de risco (3.9\%), de acordo com o U.S. Department of Health and Human Services (2018) e, em média, valores superiores semanais de atividade física (8.6 \pm 4.9$)$, comparativamente aos participantes das atividades de Levadas e de Veredas. No entanto, as diferenças entre os grupos apenas apresentam significado estatístico 
nas variáveis de prática desportiva e fator de risco para atividade física $(\mathrm{p}<0,05)$.

Tabela 2. Perfil socioecónomico dos participantes.

\begin{tabular}{lccccc}
\hline Características & Total & $\begin{array}{c}\text { Levadas } \\
(\mathbf{n = 2 2 2})\end{array}$ & $\begin{array}{c}\text { Veredas } \\
(\mathbf{n = 1 7 6})\end{array}$ & $\begin{array}{c}\text { BTT } \\
(\mathbf{n = 5 1})\end{array}$ & $\boldsymbol{p}$ \\
\hline Nível de escolaridade (\%) & & & & & \\
$\quad$ Ensino Básico e Secundário & $45.9 \%$ & $40.9 \%$ & $53.2 \%$ & $43.1 \%$ & 0,048 \\
$\quad$ Ensino Superior & $54.1 \%$ & $59.1 \%$ & $46.8 \%$ & $56.9 \%$ & \\
$\quad \begin{array}{l}\text { Condição Profissional (\%) } \\
\quad \text { Ativo }\end{array}$ & $72.3 \%$ & $72.2 \%$ & $67.5 \%$ & $89.5 \%$ & 0,015 \\
$\quad$ Inativo & $27.8 \%$ & $27.8 \%$ & $32.5 \%$ & $10.9 \%$ & \\
\hline
\end{tabular}

Tabela 3. Perfil de atividade física participantes: uma análise por grupo de atividade realizada.

\begin{tabular}{lccccc}
\hline Características & $\begin{array}{c}\text { Total } \\
(\mathbf{n = 4 9 9})\end{array}$ & $\begin{array}{c}\text { Levadas } \\
(\mathbf{n = 2 2 2})\end{array}$ & $\begin{array}{c}\text { Veredas } \\
(\mathbf{n = 1 7 6})\end{array}$ & $\begin{array}{c}\text { BTT } \\
(\mathbf{n = 5 1 )}\end{array}$ & $\boldsymbol{p}$ \\
\hline Prática Desportiva (\%) & & & & & \\
$\quad$ Sim & $86.4 \%$ & $80.9 \%$ & $89.8 \%$ & $98.0 \%$ & 0,001 \\
$\quad$ Não & $13.6 \%$ & $19.1 \%$ & $10.2 \%$ & $2.0 \%$ & \\
Fator Risco AF (\%) & & & & & \\
$\quad$ Ausência & $80.6 \%$ & $78.8 \%$ & $77.8 \%$ & $96.1 \%$ & 0,011 \\
$\quad$ Fator de Risco & $19.4 \%$ & $21.2 \%$ & $22.2 \%$ & $3.9 \%$ & \\
AF Semanal (h.semana) & $6.9 \pm 6.0$ & $6.8 \pm 6.9$ & $6.5 \pm 5.4$ & $8.6 \pm 4.9$ & 0,099 \\
\hline
\end{tabular}

\section{Condição de Realização da Atividade}

Os participantes foram igualmente inquiridos sobre a atividade desenvolvida (Levadas, Veredas e BTT), nomeadamente se a mesma foi dinamizada por alguma empresa e se envolveu pernoitar fora do alojamento. Constata-se que em média sensivelmente um em cada quatro turistas $(24.2 \%)$ realizou a atividade no âmbito de uma empresa, sendo que o recorrer aos serviços de empresas está associado à atividade desenvolvida nomeadamente ao BTT $(p<0,05)$. Neste contexto verifica-se que $100 \%$ dos turistas que realizaram a atividade de BTT, realizaram-na através de uma empresa, contrariamente ao valor, bastante inferior, que foi registado nas Levadas (11.4\%) e nas Veredas (18.2\%).

Aproximadamente metade dos turistas (45.3\%), reportou pernoitar fora do seu alojamento para realizar a atividade, sendo muito similares os valores entre os participantes nas três atividades $(\mathrm{p}>0,05)$, $44.7 \%$ nas Levadas, $50.0 \%$ nas Veredas e $31.4 \%$ no BTT.

\section{Discussão}

\section{Características Demográficas}

De uma maneira geral, verificou-se equilíbrio entre homens e mulheres nos grupos G1 e G2, com as percentagens a variar entre os $42 \%$ e os $58 \%$, com as mulheres a marcarem mais presença, contrariamente a outros estudos que obtiveram valores semelhantes, mas com prevalência dos homens. É o caso do estudo de Assaf, Barros, e Machado (2013) que referem $56.6 \%$ de homens e $43.4 \%$ de mulheres a visitar a Ilha da Madeira, ou de Machado e Barros (2010) em que os visitantes da Madeira tendem a ser $52 \%$ homens e $48 \%$ mulheres.

$\mathrm{Na}$ comparação com outros eventos de grande impacto turístico, o Observatório do Turismo na Madeira, em doze recolhas diferentes realizadas entre 2016 e 2019, apresenta dados estatísticos onde se verifica algum equilíbrio entre homens e mulheres nos eventos do Carnaval, Festa da Flor, Festival do Atlântico e Fim do Ano com os valores de ambos entre os $40 \%$ e os $60 \%$, estes sim em linha com os resultados do nosso estudo e muito próximos.

Tais dados permitem verificar que ambos os géneros valorizam as atividades na Natureza e a participação em eventos turísticos em meio urbano de modo semelhante. Existe um certo equilíbrio de género na adesão a estas atividades.

No entanto, no BTT, estão em evidente maioria os indivíduos do género masculino (92.2\%). Estes valores não se enquadram com alguma da bibliografia consultada (Meschik, 2012; Faulks, Ritchie \& Fluker, 2007) mas estão em linha com estudos mais recentes, feitos em Portugal (Campelo, 2015) e Brasil (Santos, Morais, Souza, Mendes, \& Oliveira, 2016), em investigações do mesmo género e relativas a esta atividade.

Sendo a amostra desta atividade ainda reduzida e não tendo sido explorados outros cenários, onde o BTT tem lugar, pode-se deduzir que poderá ter havido influência do percurso onde foi feita a recolha, que apresenta zonas de declive acentuado e trilhos/corredores não muito largos. Um percurso que parece ser sugerido mais aos indivíduos do género masculino pelo agente turístico ou que simplesmente não atrai tantos indivíduos do género feminino, indicando uma clara diferença de valorização do tipo de atividade turística entre géneros. 
$\mathrm{Na}$ componente da idade, os valores médios apresentados entre G1 e G2 são aproximados (G1: 41.5 $\pm 16,0$ anos; G2: 42.9 \pm 17.2 anos). Não se verificam diferenças significativas entre o grupo que faz Levadas e o que realiza caminhadas pelas Veredas.

Os valores verificados estão de acordo com a nova tendência dos "Babyboomers" e "Millennials", populações que procuram atividades inovadoras, de prática saudável na natureza e de baixo custo (Ijspeert, 2017; Assaf et al., 2013; Barros \& Machado, 2010). Nestes estudos os autores referem valores médios de idade entre os 39.87 e os 44 anos, ainda assim, abaixo de outros já publicados (Almeida et al., 2019), com uma média de idades de 56 anos.

Os dados do Observatório do Turismo da Madeira (2016-2019) para quem visita a Ilha da Madeira no Carnaval, Festa da Flor, Festival do Atlântico e Fim do Ano apresentam médias de idade entre os 50 e os 60 anos, valores próximos aos obtidos neste estudo, relativamente aos que realizaram caminhadas em Veredas (43-60) e em Levadas (42-58), mas bastante superiores às idades dos participantes no percurso BTT (37-45).

O BTT apresentou uma média de idades $(36.73 \pm 9,0)$ inferior à verificada nos outros dois grupos (G1 e G2), sendo que as diferenças eram estatisticamente significativas. Esta média, apesar de se aproximar da reportada por Moran et al. (2006), é inferior, em cerca de dez anos, quando comparada com outros estudos que caracterizavam os praticantes de BTT para fins turísticos. Como exemplo, Meschik (2012) refere valores médios de 45.6 anos de idade e Reis et al. (2014), que no seu estudo referem que $49.4 \%$ dos inquiridos tinha uma idade superior a 55 anos de idade.

A baixa média de idades, em comparação com outras atividades turísticas, pode estar associada à sensação de perigo e de aventura da atividade em si, em que as pessoas mais jovens se sentem mais confortáveis e motivadas a participar no BTT. O facto de a média de idades ser mais baixa, comparada com outros estudos, poderá estar relacionada com a dificuldade do trilho selecionado, sendo necessário aumentar a amostra e os cenários de BTT analisados de modo a contribuir para o aprofundar desta discussão.

Enquanto nas atividades G1 e G2 o grupo mais representado eram os turistas de origem Portuguesa $(\mathrm{G} 1=26.6 \% ; \mathrm{G} 2=21.7 \%)$ no BTT só $3.9 \%$ eram portugueses.

Estes dados indicam que na Ilha da Madeira, para o percurso analisado, os principais adquirentes dos produtos de BTT são estrangeiros. Assim sendo, pode-se pensar que o mercado português tem larga margem de expansão no BTT, uma vez que nos outros grupos (G1: $26.6 \%$ e G2: $21.7 \%$ ) é português o grupo de turistas que em maior percentagem realiza atividades na Natureza, nos percursos analisados no presente estudo.
Quando comparados com outros estudos, o envolvimento dos portugueses no G1 e G2 está acima do reportado pelo observatório do turismo no Carnaval (2017: 9\%; 2018: 10\%), Festa da Flor (2016: 12.2\%; 2017: 18\%; 2018: 12\%), Festival do Atlântico (2016: 4\%; 2017: 14\%; 2018: 8\%) e Fim do Ano (2016: 13.2\%; 2017: 17\%; 2018: 15\%).

Estes dados parecem indicar que há ainda uma potencial margem para aumentar o número de estrangeiros que visita a Madeira para participar nas atividades de G1 e G2, que apesar de representarem sensivelmente $73.4-78.3 \%$ da amostra, estão ainda aquém dos 82 - 91\% que representam noutros eventos de grande impacto turístico para a Ilha da Madeira.

Por outro lado, os dados parecem indicar que a atividade BTT tem um público alvo próprio, que se distingue claramente dos outros que participam nos festivais urbanos e mesmo dos que realizam as Levadas e Veredas.

Estes resultados, que consideramos importantes como indicadores dos mercados de origem em diferentes atividades, devem, no entanto, ser objeto de confirmação com novos estudos, que abarquem mais cenários e atividades de Desporto de Natureza, com uma amostra mais robusta.

\section{Características Socioeconómicas}

A nível socioeconómico, este estudo apresenta valores aproximados aos verificados na bibliografia, para todos os grupos (G1, G2 e BTT).

A maioria dos inquiridos possui um grau académico do ensino superior $(54.1 \%)$ como se pode também verificar na bibliografia consultada (IJspeert, 2017; Tomás, 2009; Moran et al., 2006) e em linha com os valores apresentados pelo Observatório do Turismo da Madeira para os eventos do Carnaval, Festa da Flor, Festival do Atlântico e Fim do Ano.

Almeida et al. (2019) publicaram os valores reportados por este Observatório que demonstravam que, quem visita a Ilha da Madeira para os referidos eventos, é na sua maioria detentora de um grau académico superior (54\%).

Verifica-se também que no geral a população que se dedica a este tipo de atividades é trabalhadora ativa (G1: 72.2\%; G2: 67.5\%; BTT: $89.5 \%$ ) sendo que o restante valor é distribuído entre estudantes e reformados.

Temos então uma população instruída e ativa, que visita a Ilha da Madeira para fins recreativos e possivelmente para fugir da rotina do dia a dia, em ambientes urbanos. Este dado está de acordo com o referido por Barbosa e Rego (1999) e pelos autores Kastenholz e Rodrigues (2007) e Rodrigues, Kastenholz, e Rodrigues (2010). Temos uma população que procura espaços naturais onde possa desenvolver atividade física e para desfrutar o ambiente cénico que a Ilha proporciona. 


\section{Perfil de Atividade Física}

Os valores de atividade física semanal, com médias de sete horas de atividade por semana, permitem também perceber que esta é uma amostra fisicamente ativa, para todos os grupos, comparativamente à população adulta em geral.

Tal é reforçado pela grande maioria dos participantes atingir os valores recomendados (WHO, 2018) de atividade física $(80,6 \%)$.

No entanto, constata-se uma grande discrepância entre os participantes nos níveis de atividade física reportada, evidente pelo elevado desvio padrão, em particular entre os participantes das Levadas e das Veredas.

O grupo do BTT reporta possuir uma prática desportiva superior, comparativamente ao G1 e G2. $\mathrm{Na}$ nossa opinião tal parece ser sustentado por dois aspetos: (i) fatores demográficos inerentes ao grupo de BTT, em média mais novos e maior proporção homens (Mabry, Reeves, Eakin, \& Owen, 2010), características associadas a maiores níveis de atividade física (Choi, Lee, Lee, Kang, \& Choi, 2017) e (ii) os requisitos e as exigência motoras necessárias à atividade (BTT, Levadas e Veredas) serem diferentes e indiretamente associados a níveis de atividade física.

\section{Conclusão}

Face aos resultados obtidos e respondendo aos objetivos do estudo, podemos afirmar que o turista que participa nas atividades analisadas, se caracteriza por, maioritariamente, possuir uma formação de nível superior, bem como hábitos de atividade física regular, com uma maioria significativa a realizar pelo menos trinta minutos de atividade física regular diária.

Estes turistas apresentam uma média de idades entre os 41- 60 anos, equilibrada do ponto de vista da sua composição relativamente ao género, embora as mulheres representem $51.7 \%$ da população estudada. É uma população maioritariamente ativa profissionalmente, mais de $70 \%$, com origem em vinte e um países diferentes destacando-se como principais mercados emissores Portugal (22\%), Alemanha (19.2\%), França (13.6\%) e Espanha $(8.7 \%)$

Existem diferenças entre os três grupos, principalmente entre o grupo do BTT e os restantes. Este grupo, maioritariamente $(90.3 \%)$ constituído por turistas não residentes em Portugal, é mais jovem, com uma idade média (37-47) inferior aos restantes, e apresenta maior percentagem com habilitação superior e de atividade profissional, bem como reporta uma atividade física habitual semanal superior aos componentes dos outros grupos.

Quando comparamos com os turistas que visitam a Madeira durante a Festa da Flor, do Festival do Atlântico, do Fim do Ano e do Carnaval, do ponto de vista da sua composição é muito semelhante quanto à média de idades, nível de formação e composição relativamente ao género, quando comparados com os grupos das Levadas e Veredas. No entanto, diferente quanto aos mercados emissores, já que enquanto um dos principais mercados emissores de turistas para a Madeira, o Reino Unido, representa apenas um número residual no nosso estudo, com valores inferiores a $4 \%$.

Nesta comparação fica também clara a distinção entre estes turistas que visitam a Madeira durante os Festivais, Carnaval e Fim do ano e o grupo do BTT estudado, no que respeita à sua caracterização relativamente à idade, formação académica $\mathrm{e}$ profissão.

Percebe-se assim existir uma diferenciação de públicos, que interessa aprofundar através da análise de mais atividades e de cenários, de modo a perceber o que determina essa diferenciação e, assim, definir o público alvo para cada atividade bem como a melhoria das mesmas.

Do ponto de vista pedagógico-didático, os resultados obtidos permitem uma melhor adequação, quer da eventual relação direta entre os agentes turísticos, guias, gestores da atividade, com os turistas, quer no que se refere à elaboração de normas de segurança, de material de divulgação e apoio às atividades em si.

\section{Agradecimentos}

Financiado por fundos nacionais através da FCT Fundação para a Ciência e a Tecnologia, I.P., no âmbito do projeto referência $\mathrm{n}^{\mathrm{o}}$ : UIDB/04470/2020.

\section{Referências}

Almeida, A. (2016). Modelling tourism demand in Madeira since 1946: And historical overview based on a time series approach. Journal of Spatial Organization Dynamics. 1(2), 145-156.

Almeida, A., Teixeira, S., \& Franco, M. (2019). Uncovering the factors impacting visitor's satisfaction: evidence from a portfolio of events. Int. J. Event Festiv. Manage. 10(3), 217-247.

Almeida, A., \& Correia, A. (2010). Tourism development in Madeira: an analysis based on the life cycle approach Tourism Economics. Tourism Economics. 16(2), 427-441.

Almeida, A. (2010). From Island mass tourism to rural tourism in Madeira: Is there a place for a re-definition of islands' image? Revista de Estudos Politécnicos. $8(14), 97-110$

Assaf, A., C. Barros., \& Machado, L. (2013). Covariates of repeat tourism: an endogenous switching Poisson model. Tourism Economics. 19(3), 531-542.

Baptista, J. (2005). A Evolução do Turismo na Madeira no período de 1975 a 2000. Edição Autor: Funchal. 
Barbosa, A., \& Rego, C. (1999). "Recreio e turismo" in João F. (Ed.), Ambiente e emprego: situação actual e perspectivas. Instituto de Ciências Sociais da Universidade de Lisboa, Lisboa, pp. 277-315.

Barros, C. (2007). Analysing the relationship between sports and tourism: a case study of the Island of Madeira. International JournaSport Management Marketing, 2(5).

Barros, C., \& Machado, L. (2010). The length of stay in tourism. Annals of Tourism Research. 37(3), 692706.

Buning, R. J., \& Lamont, M. (2020). Mountain bike tourism economic impacts: A critical analysis of academic and practitioner studies. Tourism Economics, 1(10); 2-7.

Campelo, M. (2015). Caraterização do BTT no Parque Natural de Sintra-Cascais. Um contributo para a revisão da Carta de Desporto de Natureza do PNSC. (Mestrado)Universidade de Lisboa.

Cho, V. (2010). A Study of the Non-economic Determinants in Tourism Demand. International Journal of Tourism Research. 12, 307-320.

Choi, J., Lee, M., Lee, J., Kang, D., \& Choi, J.-Y. (2017). Correlates associated with participation in physical activity among adults: a systematic review of reviews and update. BMC Public Health, 17(1), 356. https://doi.org/10.1186/s12889-017-4255-2

Courtney, P. (2018). Mountain biking brings thousands of trail-riding enthusiasts to northern Tasmanian town. $\quad \mathrm{ABC}$ News. https://www.abc.net.au/news/2018-04-21/worldclass-mountain-bike-trail-transforms-derby-fromghost-tow/9677344. Acedido a 20 de Abril de 2020.

Faria, S., Tiago, M., Tiago, F., \& Couto, J. (2014). Tourism on the azores and madeira islands: issues of peripheral and development Regions. European Sciences Journal. SPECIAL edition Vol.2 ISSN: 1857 - 7881 (Print) e - ISSN 1857- 7431.

Faulks, P., Ritchie, B., \& Fluker, M. (2007). Cycle tourism in Australia: An investigation into its size and scope. Gold Coast: Sustainable Tourism Cooperative Research Centre.

Freeman, R. E. (1984). Strategic management: A stakeholder approach. Boston: Pitman.

Fernandes, F. (2011). 'A Costa da Laurissilva': a produção de um destino turistico-cultural. Revista Turismo y Patrimonio Cultural, 135-143.

Fernandes, F. (2012). “As Representações turísticas na Região Autónoma da Madeira: os discursos em torno das Levadas". Revista Turismo \& Desenvolvimento, 21(1), 23-31.

Fernandes, F. (2015). O estudo dos sistemas turísticos e a antropologia. Madeira: um estudo de caso. Revista Turismo y Patrimonio Cultural. 13(2), 425-434.
Fernandes, F. (2016). Built heritage and flash floods: hiking trails and tourism on Madeira Island. Journal of Heritage Tourism. 11(1), 85-95.

Florido, J. (2010). Turismo activo sostenible y esperiencia óptima en espacios naturales protegidos de Andalucia. (Doctoral Thesis).

França, J. (2016). Turismo Ativo na Madeira: contributo para a rentabilidade de unidades de turismo no espaço rural. (Master Thesis). Instituto Politécnico do Porto, Escola Superior de Estudos Industriais e de Gestão.

Franco, B., Nogueira , M., Magalhães, F., \& Silva, D. (2018). Monitoring Walkers and Hikers of Madeira Island through web-share services. In, J. Dehez (Ed.), Proceedings of the 9th International Conference on Monitoring and Management of Visitors in Recreational and Protected Areas (MMV) (pp. 7577). Bordeaux Sciences Agro/irstea.

Gómez-Martín, B. (2019). Hiking Tourism in Spain: Origins, Issues and Transformations. Sustainability, 11(13), 3619. doi:10.3390/su11133619.

IJspeert, R. (2017). Charactherizing active sport tourists: millennials versus Baby boomers. (Master Thesis). School of Tourism and Hospitality Management Sant Ignasi- Ramon. Llull University.

ISMERI Europa. (2011). Growth Factors in the Outermost Regions. European Union Regional Policy. Final Report (vol. 1).

Kastenholz, E., \& Rodrigues, Á. (2007). Discussing the Potential Benefits of Hiking Tourism in Portugal. Anatolia, 18(1), 5-21.

Kelly, C. (2014). Fat Tire Flyer: Repack and the Birth of Mountain Biking. Boulder, CO: VeloPress.

Mabry, R. M., Reeves, M. M., Eakin, E. G., \& Owen, N. (2010). Evidence of physical activity participation among men and women in the countries of the Gulf Cooperation Council: a review. Obesity Reviews, 11(6), 457-464.

Machado, L., Santos, C., \& Sarmento, M. (2009). Madeira Island - destination image and tourists loyalty. European Journal of Tourism Research. 2(1), 70-91.

Machado, L. (2011). The consequences of natural disasters in touristic destinations: The case of Madeira Island - Portugal. Tourism Hospitality Research. 12(1), 55-56.

Marujo, N. (2013). O desenvolvimento do turismo na Ilha da Madeira. Revista Investigação Turismo. Desarrolo Loc. 6(15).

Marujo, N. (2014). Tourism and special events: the Flower Festival in Madeira Island. Tourism Management Studies, 10(2), 26-31.

McQuilkin S. (2013). Destination image of Portugal through the viewpoint of British tourists: Analysis of 
online blogs and reviews. (Mestrado) Faculdade de Letras da Universidade do Porto.

Meschik, M. (2012). Sustainable cycle tourism along the Danube Cycle Route in Austria. Tourism Planing Development, 9(1), 41-56.

Melo,„R., Gomes, R. (2017). Nature sports participation: Understanding demand, practice profile, motivations and constraints. European Journal Tourism Research, 16(108-135).

Moran, D., Tresidder, E., \& McVittie, A. (2006). Estimating the recreational value of mountain biking sites in Scotland using count data models. Tourism Economics, 12(1), 123-135.

Nogueira, R., Silva, A., Grilo, C., Rosalino, L., \& Silva, C. (2012). MTB monitoring in Arrábida Natural Park, Portugal. In, P. Fredman et al. (Eds.), Proceedings of The 6th International Conference on Monitoring and Management of Visitors in Recreational and Protected Areas: Outdoor Recreation in Change Current Knowledge and Future Challenges. pp. 3233

Oliveira, P., \& Pereira, P. (2008). Who values what in a tourism destination? The case of Madeira Island. Tourism Economics, 14(1), 155-168.

RAM. (2016). Estratégia para o turismo da madeira 2017-2021, Região Autónoma da Madeira. https://estrategia.turismodeportugal.pt/sites/default/fi les/Doc_Estrategico_Turismo_RAM_0.pdf

Reis, C., \& Jellum, C. (2012). Rail trails as significant tourism products: A conceptual model for sustainable tourism. Tourism Planing Development, 9(2), 133 148.

Reis, A., Lovelock, B., \& Jellum C. (2014). Linking tourism products to enhance cycle tourism: the case of the Taieri Gorge Railway and the Otago Central Rail Trail, New Zealand. Tourism Review International. 18, 57-69.

Rodrigues, Á., Kastenholz, E., \& Rodrigues, A. (2010). Hiking as a relevant wellness activity - results of an exploratory study of hiking tourists in Portugal applied to a rural tourism project. J Vacat Marketing, 16(4), 331-343. doi:10.1177/1356766710380886.

Rodrigues, A., \& Virtudes, A. (2019). A Smart Rural Project for Tourism of Madeira Island. IOP Conf. Ser. Journal Material Science. doi:10.1088/1757899X/471/9/092042.

Santos, A., Morais, K., Souza, F., Mendes, C., \& Oliveira, V. (2016). Análise do Perfil dos Praticantes de Mountain Bike (MTB) da Cidade de Trindade (GO). Revista Vita et Sanitas, Trindade, 10 (1)22-37.

Tomás, P. (2009). Património construído e desenvolvimento em áreas de montanha. O exemplo da Serra da Lousã. Câmara Municipal da Lousã.
Turismo de Portugal (2006). 10 produtos estratégicos para o desenvolvimento do turismo em Portugal. Turismo de Portugal, Instituto Politécnico de Lisboa.

U.S. Department of Health and Human Services (2018). Physical Activity Guidelines for Americans, 2nd edition. Washington, DC: U.S. pp. 56.

Valls, J., Mota, L., Vieira, S., \& Santos, R. (2019). Opportunities for Slow Tourism in Madeira. Sustainability, 11, 4534.

Velvet, N. (2015). Tourist Identities in Narratives of Unexpected Adventure in Madeira. International Journal of Tourism Research. 17, 537-544.

Word Health Organization (2018). Physical activity. https://www.who.int/news-room/factsheets/detail/physical-activity 


\title{
Experiência Flow em Atividades de Desporto de Natureza na Madeira
}

\author{
Catarina Fernando $^{1,2}$, Hélder Lopes ${ }^{1,2}$, João Noite ${ }^{1,2}$, Ana Rodrigues ${ }^{1,2}$, \\ Ricardo Alves $^{1,2}$, João Prudente ${ }^{1,2}$
}

\author{
${ }^{1}$ Universidade da Madeira (UMA) \\ ${ }^{2}$ Centro de Investigação, Desenvolvimento e Inovação em Turismo (CITUR)
}

\begin{abstract}
Palavras-chave
Levadas;

Veredas;

BTT;

Flow;

Experiência

\section{RESUMO:}

O objetivo deste estudo é caracterizar a experiência Flow nas atividades de levadas, veredas e bicicleta todo o terreno e analisar as diferenças na perceção desta por parte dos participantes. A pesquisa foi realizada através da aplicação de um questionário, após a realização da atividade, a uma amostra de 449 indivíduos de 21 nacionalidades diferentes. A amostra é composta por 217 indivíduos do género masculino e 232 do género feminino, sendo a média de idades de 41.5 \pm 16.1 . De acordo com os resultados obtidos na análise conjunta das atividades destaca-se a escala espaço natural, como o aspeto mais valorizado pelos praticantes, e a escala motivação dos participantes como aspeto menos valorizado. $\mathrm{Na}$ análise dos indicadores demográficos, constatam-se diferenças no perfil dos participantes das três atividades $(\mathrm{p}<0,05)$. Os participantes da atividade de bicicleta todo o terreno, destacam-se dos participantes que realizaram as levadas e as veredas $(\mathrm{p}<0,05)$, sendo em média mais novos e em maior proporção do sexo masculino. Nos resultados de comparação das três atividades, a descrição da experiência Flow, é reportada de modo distinto pelos participantes de cada uma das atividades $(p<0,05)$ e apenas na escala cenário natural, não se detetaram diferenças $(p=0,110)$ entre nenhuma delas. Em síntese, consideramos que através dos resultados apresentados é possível concluir que este tipo de atividades pode proporcionar a vivência de experiências Flow e que o instrumento utilizado permite-nos caracterizá-las.
\end{abstract}

\section{Keywords Levadas; Hiking; MTB; Flow; Experience}

\section{The flow experience in nature sport activities in Madeira}

\section{ABSTRACT:}

The goal of the present study is to characterize the Flow Experience in activities as Levadas, Hiking and Mountain Biking. We aim to analyse the differences between practitioners, on how they perceive their experience. A survey was applied, at the end of each activity. A sample of 449 individuals from 21 different countries was collected. From this sample 217 individuals were males and 232 females with an average age of $41.5 \pm 16.1$ years old. According to the results obtained in the joint analysis of activities, the natural space scale stands out, was the aspect most valued by practitioners. On the other hand, the motivation scale of the practitioners was the least valued aspect. On the demographic analysis, differences were found $(p<0.05)$ regarding the profile of practitioners in the three activities. Mountain bikers stand out from the Levadas practitioners and the Hikers $(p<0.05)$, being on average younger and in a greater proportion males. When comparing the three activities the description of the Flow experience is reported in a different way by the practitioners $(\mathrm{p}<0.05)$. Only in the natural scenario scale, no differences $(p=0.110)$ were verified. Overall, we consider that it is possible to conclude that this type of activities can provide the Flow experience and that the instrument used allows us to characterize it. 


\section{Experiência flow em atividades de desporto de natureza na Madeira}

A Ilha da Madeira oferece um cenário muito rico e diversificado para a prática de atividades ao ar livre, as levadas e veredas são das mais populares entre os turistas, mas a oferta é mais abrangente (atividades em Bicicleta Todo-o-Terreno (BTT), Canyoning, Mergulho, Surf, etc.). Face à diversidade das atividades oferecidas, mas também da população que as realiza é de extrema importância encontrar parâmetros que nos permitam estudar as experiências vivenciadas pelos indivíduos, não só para controlo da qualidade dos produtos/serviços oferecidos, mas também para poder gerir as decisões ao nível da conceção de produtos, ao nível político e até na formação de profissionais da área.

Uma das teorias que nos permite interpretar as experiências dos indivíduos na realização de uma atividade é o conceito de experiência ótima ou estado Flow. A teoria de Csikszentmihalyi (1990) refere nove componentes que fazem parte desta experiência: (1) Sentido de competência ao executar a atividade, equilíbrio entre skills e desafio; (2) Necessidade de concentração; (3) Objetivos claros; (4) Feedback imediato; (5) Sensação de envolvimento profundo e concentração na atividade; (6) Controle absoluto das ações; (7) Perda da autoconsciência; (8). Perda da noção de tempo e; (9) Experiência autotélica.

Relativamente às condições para alcançar o estado Flow, não existe um consenso na comunidade científica, há autores que defendem que o alcance de três destas dimensões são condições necessárias, respetivamente, equilíbrio entre skills e desafio, objetivos claros e feedback imediato (Nakamura \& Csikszentmihalyi, 2002) outros que defendem que todas as dimensões têm de estar presentes para que este possa ser alcançado (Schiefele, 2013, Stebbins, 2010).

O conceito de experiência Flow começou a ser aplicado ao desporto há já algumas décadas (Florido, 2010, Swann, Piggott, Schweickle, \& Vella, 2018), numa fase inicial com predominância nas atividades desportivas formais com carácter competitivo. A primazia dada à sua aplicação na competição, está relacionada com o facto de alguns autores sugerirem que os desportistas de elite experienciam este estado com maior frequência que os que o realizam atividades de forma recreativa (Catley \& Duda, 1997). No entanto, com o decorrer dos anos as aplicações desta teoria têm-se também alargado às atividades desportivas de lazer, defendendo-se não só que estas são capazes de gerar este estado, como também que este é um dos principais motivos para a sua prática (Stebbins, 2010, Cheng, Hung, \& Chen, 2015).

Numa lógica de aumentar a especificidade do instrumento em relação à situação em estudo, foi construído um instrumento próprio para avaliar a experiência Flow em atividades de turismo ativo em espaços naturais CEFEN (Florido, 2010), que se baseia em parâmetros considerados mais adequados à avaliação deste tipo de experiência. Na tentativa de enfatizar uma abordagem multidisciplinar do turismo ativo este questionário, validado por Florido (2010), tenta comtemplar cada um dos aspetos presentes neste fenómeno, nomeadamente: (i) a atividade física; (ii) a informação técnica e ambiental associada à atividade; (iii) as características dos espaços naturais em que a atividade se realiza; (iv) as motivações e expetativas dos praticantes e por último (v) a perceção da experiência vivida.

Tendo em conta este quadro conceptual é importante compreender as atividades escolhidas para este estudo à luz deste conjunto de premissas.

\section{Veredas e Levadas}

As veredas e levadas são atividades de caminhada onde o skill dominante é o andar e, portanto, do ponto de vista técnico não é à partida uma atividade muito exigente. No entanto, a necessidade de o indivíduo se adaptar ao contexto é uma constante, o que faz com que o movimento de caminhar não possa ser um gesto automático e implique uma permanente recolha de indicadores do terreno, tomada de decisão e aplicação das estratégias mais adequadas à situação (Fernando, Prudente, Lopes, \& Vicente, 2018).

O nível de atividade física exigida vai depender de fatores inerentes ao contexto como a distância do percurso, a velocidade, a inclinação, o tipo de piso, os possíveis obstáculos, a altitude, etc. (Bastien, Willems, Schepens, \& Heglund, 2005, O'Connor, Xu, \& Kuo, 2012, Davies \& Mackinnon, 2017, Nenad, Slobodan, Ciric, Ranko, \& Nebojs, 2012).

Contudo, o impacto destas variáveis na performance do indivíduo vai também correlacionar-se com a sua capacidade de adaptação e não exclusivamente com a sua capacidade física (Fernando et al., 2018).

A informação técnica e ambiental e características dos espaços naturais associadas a estas atividades, no caso da Madeira, está relativamente bem documentada existindo um conjunto de livros e aplicações onde é possível encontrar informações sobre os percursos, nomeadamente, localização, distância, declive, altitude, principais obstáculos, flora e fauna, pontos de atração, infraestruturas, etc. (Lecoq \& Francisco, 2006, Quintal, 2004). No entanto, o facto de a informação existir não quer dizer que seja passada a quem realiza a atividade sobretudo quando se verifica que muitos dos participantes fazem este tipo de atividade sem recorrer a empresas especializadas (Fernando et al., 2020).

Para diferenciar as levadas das veredas tivemos em consideração características dos espaços naturais onde as caminhadas foram realizadas. Para as levadas considerámos um contexto de floresta Laurissilva com vegetação muito abundante e pontos de água corrente, para as veredas considerámos um terreno montanhoso, fora da floresta Laurissilva, e com escassa vegetação (Quintal, 2004). Em qualquer um 
destes contextos a beleza paisagística foi um fator preponderante.

\section{BTT}

A atividade de BTT, é caracterizada por passeios de bicicleta em trilhos com irregularidades no terreno e alguns obstáculos, naturalmente, que este tipo de atividade implica o domínio do andar de bicicleta, mas também a capacidade de ir fazendo os ajustes necessários ao terreno onde se progride, quer ao nível das trajetórias, quer dos tipos de piso que vão surgindo ao longo do percurso. Esta capacidade de adaptação ao terreno é destacada por alguns autores como uma necessidade de superação das imprevisibilidades, que consideram a principal característica desta atividade (Lavoura, Schwartz, \& Machado, 2008). O nível de atividade física exigida ao praticante vai depender do percurso realizado. Há percursos com diferentes níveis de dificuldade consoante as suas características, nomeadamente, a distância do percurso, o desnível, o tipo de piso e os aspetos técnicos (FPC, 2019). A classificação da dificuldade do percurso tem em consideração a combinação destes fatores.

Sendo a totalidade da nossa pesquisa aplicada a indivíduos que realizaram esta atividade através de empresas especializadas nesta atividade e com as licenças necessárias à orientação destas, pressupõe-se que existe uma informação técnica e ambiental e que esta é passada aos indivíduos que a realizam.

Os espaços naturais onde estas atividades foram realizadas têm como características serem um terreno montanhoso fora da floresta Laurissilva e com vegetação não muito densa onde a beleza das paisagens se destaca.

Face ao enquadramento teórico realizado, com o desenvolvimento deste estudo pretende-se: (i) Caracterizar a experiência Flow em espaços naturais de praticantes de três atividades (levadas, veredas e BTT); (ii) Estudar a associação entre a experiência Flow e a idade, e as diferenças entre sexos na descrição da experiencia Flow em espaços naturais; (iii) Analisar as diferenças na descrição da experiência Flow no espaço natural, considerando a atividade vivenciada pelo participante (levadas, veredas e BTT).

\section{Método}

A recolha de dados foi realizada através da entrega de um questionário sobre experiências Flow em espaços naturais (Florido, 2010), disponível em 6 idiomas diferentes (Português, Francês, Espanhol, Inglês, Alemão e Polaco), no final de cada atividade.

O questionário (QEFENRAM) foi aplicado a sujeitos envolvidos em percursos de "Levadas na Laurissilva" (G1), "Veredas fora da Laurissilva" (G2) e atividades em Bicicleta Todo o Terreno ou "BTT" (G3).

\section{Participantes}

Nesta investigação participaram 449 visitantes de ambos os sexos (217 homens e 232 mulheres). A amostra geral divide-se assim em três grupos (G1: $\mathrm{n}=222 ; \mathrm{G} 2: \mathrm{n}=176 ; \mathrm{G} 3: \mathrm{n}=51$ ) com uma média de idade de 41,5 $\pm 16,1$ anos.

\section{Instrumentos}

Utilizou-se o "Questionário sobre experiências Flow em espaços naturais da Região Autónoma da Madeira (QEFENRAM)", adaptado de Florido (2010) com 44 frases de escolha múltipla (Sim, Não e Não entendo) e uma secção de caracterização da amostra onde se recolhiam informações sobre o género, idade, número de horas dedicadas semanalmente à prática de desporto, profissão, habilitações académicas e país de residência.

Este questionário permite a extração de seis escalas que caracterizam a experiência Flow em espaços naturais e que resultam da soma de diversas afirmações: (i) Escala 1: Informações no início da atividade (procura estimar as informações que os participantes receberam no início da atividade); (ii) Escala 2: Exigência de interação e de atenção (pretende estimar a perceção dos participantes em relação à exigência de interação e atenção que a atividade apresenta); (iii) Escala 3: Espaço natural (refere-se à perceção dos praticantes do espaço natural no que a atividade foi realizada em termos de interesse, atratividade e valor da paisagem); (iv) Escala 4: Motivações dos praticantes (pretende caracterizar as motivações que levam os praticantes a realizar a atividade naquele local específico); (v) Escala 5: Predisposição dos praticantes (refere-se ao ponto de partida com o qual os participantes acedem à atividade em relação à sua autoconfiança, experiências e expectativas anteriores sobre a atividade); (vi) Escala 6: Experiência ideal dos praticantes (refere-se à perceção da experiência vivida pelos praticantes, o grau de concentração desenvolvido, o progresso na habilidade e controle de movimentos, a sensação de superar um desafio e a sensação de estar integrado com o grupo e com o espaço natural.

Os valores do alfa de Cronbach nas escalas oscilaram entre 0,696 e 0,782 .

\section{Procedimentos}

Os dados foram recolhidos entre julho de 2019 e janeiro de 2020 por uma equipa de sete investigadores da Universidade da Madeira, que não tinham qualquer relação com os sujeitos que pertencem à amostra.

De todos os questionários recolhidos, quatrocentos e vinte foram recolhidos em papel, diretamente no local da atividade, após a sua conclusão, e vinte e nove foram recolhidos através do preenchimento on-line, tendo sido entregue um $Q R$ code e um link direto para a página do questionário. 
Para garantir a aleatoriedade da amostra foram seguidos os seguintes passos: no final da atividade eram entregues sete questionários às pessoas que chegavam ao ponto de repouso final, de maneira consecutiva; foi entregue um questionário por cada participante que quisesse colaborar; só após todos os sete questionários serem devolvidos à equipa de investigadores $\mathrm{e}$ depois dos inquiridos terem abandonado o local de recolha é que se procedia à entrega de sete novos questionários. Este procedimento decorria por seis horas.

Em alguns momentos um só grupo de pessoas esgotava os sete questionários e noutros momentos eram envolvidas pessoas de grupos diferentes. Recolheram-se sensivelmente cinquenta questionários por dia (dia $1=51$; dia $2=54$; dia $3=48$; dia 4=57; dia $5=54$; dia $6=51$; dia $7=54$;) sendo que vinte e nove foram recolhidos on-line e os 51 elementos do "BTT" colaboraram em 5 dias diferentes, dada a especificidade da atividade (dia $1=7$; dia $2=18$; dia $3=6$; dia $4=7$; dia $5=13$ ).

\section{Análise estatística}

Numa primeira fase procedeu-se a uma análise exploratória dos dados de modo a identificar possíveis erros de entrada de dados, bem como estudo da distribuição das variáveis quantitativas. A média e o desvio padrão, foram utilizadas para caracterizar a amostra nas variáveis em estudo.

O teste estatístico do qui-quadrado, foi utilizado para determinar a associação entre o género e o grupo de atividade realizada. $\mathrm{O}$ teste $\mathrm{T}$-Student, foi utilizado para estudar as diferenças médias entre sexos, nas escalas de caracterização da experiência Flow em espaços naturais. Para determinar as diferenças entre os praticantes dos 3 grupos de atividade (levadas, veredas e BTT), nas escalas de experiência Flow recorreu-se a Anova a um fator, com Post Hoc através do teste de Bonferrioni.

As correlações de Pearson permitiram determinar a associação entre a idade e as escalas da experiência Flow, as correlações parciais avaliaram as mesmas associações, no entanto com controlo da atividade realizada e sexo.

Todo o procedimento estatístico desenvolvido ocorreu no software SPSS versão 26.0. O nível de significância adotado foi de $5 \%$.

\section{Resultados}

A apresentação dos dados referentes a descrição da experiência Flow em espaços naturais pelos participantes foi realizada segundo: (i) análise da experiência Flow em espaços naturais nas três atividades (levadas, veredas e BTT); (ii) análise de diferenças entre sexos; (ii) uma associação com a idade e; (iii) uma análise das diferenças entre os participantes de três atividades (levadas, veredas e BTT).

Análise da experiência Flow em espaços naturais Das seis escalas analisadas a escala espaço natural, é o aspeto mais valorizado pelos praticantes e a escala motivação dos participantes o menos valorizado, considerando a amplitude de cada escala (tabela 1). Com exceção da motivação, os valores atribuídos às outras escalas somam todos uma percentagem acima dos $58 \%$ de respostas positivas relativamente à importância das diferentes escalas consideradas, o que denota uma valorização destas por parte dos praticantes.

Tabela 1. Caracterização da experiência Flow em espaços naturais (média \pm desvio padrão).

\begin{tabular}{lcc}
\hline Escala (amplitude) & $\begin{array}{c}\text { Total } \\
(\mathbf{n = 4 9 9 )}\end{array}$ & $\boldsymbol{p}$ \\
\hline 1. Informação (0-4) & $2.7 \pm 1.6$ & 0,381 \\
2. Exigência de inter. e atn. (0-5) & $2.9 \pm 1.6$ & 0,271 \\
3. Espaço Natural (0-7) & $6.6 \pm 1.0$ & 0,825 \\
4. Motivação dos Prts (0-12) & $5.4 \pm 2.4$ & 0,702 \\
5. Predisposição dos Prts (0-5) & $4.1 \pm 1.2$ & 0,242 \\
6. Experiência ideal dos Prts (0-11) & $6.9 \pm 2.7$ & 0,416 \\
\hline \multicolumn{3}{l}{ Legenda: Prts - Participantes; Exigência de inter. e atn. - } \\
Exigência de interação e atenção & &
\end{tabular}

\section{Análise entre sexos}

Entre os dois sexos, verifica-se que em média os homens apresentam valores superiores em todas as escalas analisada à exceção das escalas espaço natural e motivação dos participantes. Contudo, em nenhuma das escalas se verificam diferenças com significado estatístico $(\mathrm{p}>0,05)$ (tabela 2$)$.

\section{Associação com a idade}

Considerando as escalas avaliadas constata-se associações significativas negativas entre a idade e: (i) a exigência de interação e atenção $(r=-0,235$; $\mathrm{p}<0,001)$ e (ii) a experiência ideal dos praticantes ( $\mathrm{r}=$ $185 ; \mathrm{p}=0,018$ ). Controlando a atividade realizada e o sexo, as associações existências entre a idade e as escalas exigência de interação e atenção $(r=-0,320$; $<0,001)$ e a escala experiência ideal dos praticantes $(\mathrm{r}=-0,182 ; \mathrm{p}=0,018)$ mantiveram-se negativas $\mathrm{e}$ significativas, sendo que uma maior valorização destas escalas está associada aos participantes mais jovens. 
Tabela 2. Caracterização da experiência Flow em espaços naturais: uma análise por género (média \pm desvio padrão).

\begin{tabular}{lcccc}
\hline Escala (amplitude) & $\begin{array}{c}\text { Total } \\
(\mathbf{n = 4 9 9 )}\end{array}$ & $\begin{array}{c}\text { Sexo Masculino } \\
(\mathbf{n = 2 1 7})\end{array}$ & $\begin{array}{c}\text { Sexo Feminino } \\
(\mathbf{n = 2 3 2})\end{array}$ & $\boldsymbol{p}$ \\
\hline 1. Informação (0-4) & $2.7 \pm 1.6$ & $2.8 \pm 1.5$ & $2.6 \pm 1.6$ & 0,381 \\
2. Exigência de inter. e atn. (0-5) & $2.9 \pm 1.6$ & $3.0 \pm 1.6$ & $2.8 \pm 1.6$ & 0,271 \\
3. Espaço Natural (0-7) & $6.6 \pm 1.0$ & $6.5 \pm 1.0$ & $6.6 \pm 1.0$ & 0,825 \\
4. Motivação dos Prts (0-12) & $5.4 \pm 2.4$ & $5.3 \pm 2.4$ & $5.4 \pm 2.5$ & 0,702 \\
5. Predisposição dos Prts (0-5) & $4.1 \pm 1.2$ & $4.2 \pm 1.1$ & $4.0 \pm 1.3$ & 0,242 \\
6. Experiência ideal dos Prts (0-11) & $6.9 \pm 2.7$ & $7.0 \pm 2.8$ & $6.8 \pm 2.7$ & 0,416 \\
\hline
\end{tabular}

Legenda: Prts - Participantes; Exigência de inter. e atn. - Exigência de interação e atenção

Análise das diferenças entre os participantes nas "Levadas", veredas e BTT

Numa análise aos indicadores demográficos, constata-se diferenças no perfil dos participantes das três atividades $(\mathrm{p}<0,05)$. Os participantes da atividade de BTT, destacam-se dos participantes que realizaram as levadas e as veredas $(p<0,05)$, sendo em média mais novos e em maior proporção do sexo masculino (tabela 2).

A descrição da experiência Flow, foi reportada de modo distinto pelos participantes das três atividades $(\mathrm{p}<0,05)$, sendo que apenas na escala cenário natural, não se detetaram diferenças $(\mathrm{p}=0,110)$.

Nas escalas informação, predisposição dos praticantes e na experiência ideal dos praticantes, as diferenças entre os grupos registam-se nomeadamente entre os participantes que realizaram a atividade de BTT, com os que realizaram as atividades de levadas e de veredas. $\mathrm{Na}$ escala motivação, as diferenças ocorrem entre os participantes na atividade de levadas e de BTT. Na exigência de interação e atenção, as diferenças ocorram entre os 3 grupos. Em todas as escalas os participantes que realizaram a atividade de BTT, valorizaram mais a experiência Flow, comparativamente aos participantes que realizaram as levadas ou as veredas (tabela 3 ).

Tabela 3. Descrição da experiência Flow em espaços naturais: uma análise por atividade realizada (média \pm desvio padrão).

\begin{tabular}{|c|c|c|c|c|c|}
\hline Escala (amplitude) & $\begin{array}{c}\text { Levadas } \\
(\mathrm{n}=\mathbf{2 2 2})\end{array}$ & $\begin{array}{l}\text { Veredas } \\
(n=176)\end{array}$ & $\begin{array}{c}\text { BTT } \\
(n=51)\end{array}$ & $p$ & $\overline{\text { Contrast }}$ \\
\hline Idade (anos) & $41.5 \pm 16.1$ & $42.9 \pm 17.2$ & $36.73 \pm 9.0$ & 0,020 & 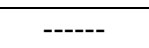 \\
\hline \multicolumn{6}{|l|}{ Sexo $(\%)$} \\
\hline Homens & $43.2 \%$ & $42.0 \%$ & $92.2 \%$ & $<0,001$ & ------ \\
\hline Mulheres & $56.8 \%$ & $58.0 \%$ & $7.8 \%$ & & \\
\hline 1. Informação (0-4) & $2.6 \pm 1.7$ & $2.5 \pm 1.6$ & $3.4 \pm 0.8$ & $<0,001$ & $\begin{array}{l}\mathrm{V}<\mathrm{BTT} \\
\mathrm{L}<\mathrm{BTT}\end{array}$ \\
\hline 2. Exg. inter. e atn. (0-5) & $2.5 \pm 1.7$ & $3.1 \pm 1.5$ & $3.8 \pm 1.3$ & $<0,001$ & $\mathrm{~L}<\mathrm{V}<\mathrm{BTT}$ \\
\hline 3. Espaço Natural (0-7) & $6.5 \pm 1.1$ & $6.6 \pm 0.8$ & $6.6 \pm 0.8$ & 0,110 & -------- \\
\hline 4. Motivação. dos Prts (0-12) & $5.1 \pm 2.5$ & $5.6 \pm 2.3$ & $6.1 \pm 2.2$ & 0,013 & $\mathrm{~L}<\mathrm{BTT}$ \\
\hline 5. Predisposição dos praticantes $(0-5)$ & $3.9 \pm 1.3$ & $4.0 \pm 1.2$ & $4.8 \pm 0.5$ & $<0,001$ & $\begin{array}{l}\mathrm{L}<\mathrm{BTT} \\
\mathrm{V}<\mathrm{BTT}\end{array}$ \\
\hline 6. Experiência ideal dos praticantes $(0-11)$ & $6.4 \pm 2.9$ & $6.8 \pm 2.6$ & $9.1 \pm 1.2$ & $<0,001$ & $\begin{array}{l}\mathrm{L}<\mathrm{BTT} \\
\mathrm{V}<\mathrm{BTT}\end{array}$ \\
\hline
\end{tabular}

\section{Discussão}

Relativamente ao perfil dos participantes nas três atividades deste estudo verifica-se uma diferença nos participantes de BTT, pelo facto de em média serem mais novos e por predominarem os indivíduos do sexo masculino. Alguns estudos de caracterização do perfil dos praticantes de BTT apontam para praticantes predominantemente do sexo masculino (Campelo, 2015, Santos, Morais, Souza, Mendes, \&
Oliveira, 2016). A faixa etária predominante nestes estudos são, respetivamente, 30-54 anos e 20-39 anos, intervalos coerentes com a média de idades do nosso estudo. Já nas levadas e veredas a diferença entre os participantes dos dois sexos é baixa o que coincide com outros dados relativos a estas atividade na Madeira (Almeida, Soares, \& Alves, 2013, Fernandes, 2013) e a faixa etária média encontrada é 41 anos no primeiro estudo, valor coerente com a média encontrada no nosso estudo, e entre 55-64 anos no segundo, contudo a amostra destes estudos é 
menos de metade da nossa o que pode explicar alguma variação de valores.

O espaço natural é a escala mais valorizada em todas as atividades analisadas apesar dos diferentes cenários naturais em que as atividades foram realizadas (montanha, floresta Laurissilva) parece ser unânime que os espaços não só são atrativos como esteticamente convidativos apresentando paisagens que os participantes valorizam.

Em relação aos dados evidenciarem uma diferença nos valores da informação recebida, entre as atividades de levadas e veredas e o BTT, julgamos que a explicação poderá estar no facto destas duas primeiras atividades serem predominantemente realizadas sem um enquadramento formal de uma empresa ou guia, enquanto a totalidade da amostra do BTT foi constituída por indivíduos que realizaram a atividade através de uma empresa de animação turística.

Sendo a informação, a comunicação e interação com os clientes aspetos bastante valorizados pelas empresas de Animação Turística na orientação de atividades, numa perspetiva associada à qualidade do serviço (Lopes, 2013, Otto \& Ritchie, 1996), é natural, que a orientação de atividades trespasse essa mesma ideia para os clientes.

Apesar disso, os valores apresentados para qualquer uma das atividades está acima dos 50\% de respostas positivas para a valorização da informação.

Já na escala da Exigência de Interação e Atenção a diferença entre o BTT e as outras atividades poderá eventualmente estar relacionada com o facto de esta atividade, ser mais exigente a nível técnico, ter sido sempre realizada em grupo, implicar o domínio do material (neste caso a bicicleta). Vários autores apontam a exigência da atividade como fator influenciador da atenção (Boucher, 1992, Dosil, 2008). Na classificação de Dosil (2008), modalidades semelhantes ao BTT, aparecem na categoria de Desportos de concentração alta-constante, caracterizadas pela necessidade de manter uma atenção constante na tarefa.

Por outro lado, o facto de o BTT ser a única atividade em que a totalidade da amostra foi orientada por profissionais leva-nos a deduzir que para além de existir uma personalização da atividade, foram existindo indicações dos profissionais relativamente ao desenrolar da atividade o que pode ter contribuído para a perceção dos praticantes na necessidade de atenção (Lopes, 2013, Otto \& Ritchie, 1996).

Relativamente às diferenças entre as levadas e as veredas, será legítimo colocar a hipótese da sua explicação poder estar relacionada com o facto de dos percursos das veredas serem de dificuldade superior (em média) aos das levadas o que pode ter levado à sensação de que não seria necessária uma interação tão elevada com os outros nem tanta atenção durante a atividade.

A escala motivação dos participantes foi das mais baixas entre as escalas do questionário quando analisadas em conjunto, com um valor médio de respostas afirmativas de cerca de $45 \%$, no entanto o BTT apresenta um valor superior às outras atividades (51\%). Em estudos anteriores (Fernando et al., 2020), com a utilização deste mesmo instrumento, verificámos que apesar do valor global da escala da motivação não ser elevado, quando discriminávamos os valores entre as diferentes categorias de motivação medidas no questionário (motivação extrínseca, motivação intrínseca, motivação instrumental e automotivação) foi percetível que eram os valores mais baixos na motivação extrínseca que levavam à diminuição do valor médio desta escala. Sendo a motivação intrínseca a mais associada ao tipo de experiência Flow (Seifert \& Hedderson, 2010), talvez seja necessário discriminar estes resultados para poder ter uma melhor interpretação da perceção da experiência dos indivíduos na realização das atividades.

Quanto à predisposição dos praticantes para a atividade, na análise das três atividades é o segundo valor mais alto $(82 \%$ do valor médio de respostas positivas), apesar de numa análise individual se verificar uma diferença significativa entre o BTT e as outras duas atividades (levadas e veredas). Referindose esta categoria ao ponto de partida dos participantes para a atividade em relação à sua autoconfiança, experiências e expectativas anteriores é natural que sendo o BTT uma atividade que requer skills mais específicos que os participantes estejam mais familiarizados com a atividade e conscientes das expetativas para a sua realização. Este pressuposto é coerente com a perspetiva que define os mercados do sector de Turismo de Natureza, segundo o Turismo de Portugal (THR, 2006), onde as levadas e veredas são enquadradas na categoria soft, isto é, experiências baseadas na prática de atividades ao ar livre de baixa intensidade. Enquanto o BTT é enquadrado na categoria hard onde a prática está associada a desportos de natureza e/ou atividades que requerem um grau elevado de concentração ou conhecimento.

Por último, na categoria experiência ideal dos participantes é também notória uma diferença significativa do BTT em relação às outras atividades. Sendo os parâmetros avaliados nesta categoria (i) manutenção da atenção e concentração durante a atividade (ii) desafio sustentável e (iii) consciência da integração no contexto e no grupo, julgamos que algumas das razões anteriormente mencionadas poderão contribuir para explicar esta diferença.

A atividade de BTT é apontada como mais exigente do que as caminhadas, relativamente à necessidade de atenção e concentração na atividade (Boucher, 1992, Dosil, 2008), mas também ao nível das categorias dos desportos de natureza (THR, 2006) onde é classificada como hard, enquanto as caminhadas são classificadas como soft, o que corrobora uma diferenciação em relação à exigência da tarefa. Esta diferenciação entre atividades, tem naturalmente repercussões ao nível dos desafios apresentados aos 
praticantes, que de acordo com o que caracteriza a experiência ótima são um equilíbrio entre os skills e objetivos (Nakamura \& Csikszentmihalyi, 2002).

Relativamente à integração no contexto, sendo a capacidade de adaptação ao contexto a principal característica do BTT, na relação com a necessidade de superação das imprevisibilidades (Lavoura, Schwartz, \& Machado, 2008) seria também expectável esta diferenciação nos dados. Quanto à integração no grupo, como referimos anteriormente, no BTT as atividades foram sempre realizadas em grupo enquanto nas caminhadas só pontualmente tal aconteceu.

\section{Conclusão}

De uma forma geral, através dos resultados apresentados e tendo em consideração o instrumento utilizado, julgamos poder concluir que este tipo de atividades pode proporcionar a vivência de experiências Flow e também que é possível caracterizá-las através deste questionário (QEFENRAM).

A discriminação das diferentes escalas utilizadas, permite-nos também identificar alguns pontos onde a qualidade das experiências poderá ser melhoradas de modo a elaborar diagnósticos que nos permitam elaborar estratégias de intervenção quer ao nível da organização, gestão de espaços, formação dos profissionais, quer ao nível da orientação das atividades no terreno.

Já em relação à análise das diferenças na descrição da experiência Flow no espaço natural, considerando as atividades vivenciadas pelos participantes, apesar de ser possível identificar algumas características especificas de cada uma das atividades, consideramos que o facto de existir uma diferença na faixa etária dos participantes poderá também ter tido alguma influência nos resultados obtidos. Em estudos futuros poderá ser interessante alargar a amostra de modo a poder trabalhar com intervalos de faixas etárias de modo a perceber até que ponto esta influência a perceção da vivência Flow e quais as escalas em que tal é mais relevante de modo a podermos isolar as diferenças decorrentes só das especificidades das atividades.

\section{Referências}

Almeida, A., Soares, J., \& Alves, A. (2013). As levadas da madeira no contexto da afirmação e da confluência do turismo de natureza com o turismo ativo. Revista Portuguesa de Estudos Regionais, (33), 27-42.

Bastien, G., Willems, P., Schepens, B., \& Heglund, N. (2005). Effect of load and speed on the energetic cost of human walking. European Journal Applied Physiology, 94, 76-83.

Boutcher, S. (1992). Attention and athletic performance: an integrated approach. In Horn, T. Advances in Sport
Psychology. (pp. 251-265). Champaign: Human Kinetics Publishers.

Campelo, M. (2015). Caraterização do BTT no Parque Natural de Sintra-Cascais. Um contributo para a revisão da Carta de Desporto de Natureza do PNSC. (Mestrado), Universidade de Lisboa.

Catley, D., \& Duda, J. (1997). Psychological antecedents of the frequency and intensity of Flow in golfers. International Journal of Sport Psychology, 28, 309322.

Cheng, T., Hung, S., \& Chen, M. (2015): The Influence of Leisure Involvement on Flow Experience During Hiking Activity: Using Psychological Commitment as a Mediate Variable, Asia Pacific Journal of Tourism Research, 21(1), 1-19.

Csikszentmihalyi, M. (1990) Flow: The psychology of optimal experience, Harper \& Row, New York, NY.

Davies, S., \& Mackinnon, S. (2017). The energetics of walking on sand and grass at various speeds. Ergonomics, 49(7), 651-660.

Dosil, J. (2008). Psicología de la actividad física y del deporte. Madrid: McGraw Hill.

Fernandes, F. (2013). Pelos Caminhos da Água. As levadas e veredas da ilha da Madeira como recurso turístico. (Doutoramento) Universidade de Évora.

Fernando, C., Lopes, H., Noite, J., Rodrigues, A., Vieira, S., Alves, R., \& Prudente, J. (2020). Mountain hikes and Levada Practitioner's motivation and experience - Characterization. European Journal of Tourism, Hospitality and Recreation. 10(1): 74-82.

Fernando, C., Prudente, J., Lopes, H., \& Vicente, A. (2018). Does Decision Making Affect Heart Rate in Trails? Heart Rate Response to Treadmill Walk with and without Adaptation. American International Journal Contemporary Research, 8(1), 24-28.

Florido, J. (2010). Turismo activo sostenible $y$ esperiencia óptima en espacios naturales protegidos de Andalucía. (Doutoramento) Universidad de Málaga.

Lavoura, T., Schwartz, G., \& Machado, A. (2008). Aspectos emocionais da prática de atividades de aventura na natureza: a (re) educação dos sentidos. Revista Brasileira de Educação Física e Esportes, São Paulo, 22(2), 119-27.

Lecoq, A. \& Francisco, D. (2006). Madeira Levadas e Veredas. Livros \& Livros.

Lopes, T. (2013). Contributos para a qualidade dos serviços de Animação turística nos Açores. (Mestrado), Escola Superior de Hotelaria e Turismo do Estoril.

Nakamura, J., \& Csikszentmihalyi, M. (2002). The concept of flow. In, C.R. Snyder, \& S.J. Lopez (Eds.). 
Handbook of positive psychology (pp.89-105). New York: Oxford University Press.

Nenad, Ž., Slobodan, A., Ćirić, M., Ranko, K., \& Nebojša, R. (2012). The difference between walking and hiking of students realized as a regular teaching ativity. Gymnasium, 2(xiii), 248-254.

O’Connor, S., Xu, H., \& Kuo, A. (2012). Energetic cost of walking with increase step variability. Gait Posture, 36, 102-107.

Otto, J., \& Ritchie, J. (1996). The service experience in tourism. Tourism Management, 17(3), 165-174.

Quintal, R. (2004). Levadas e Veredas da Madeira. Edições Francisco Ribeiro.

Santos, A., Morais, K., Souza, F., Mendes, C., \& Oliveira, V. (2016). Análise do Perfil dos Praticantes de Mountain Bike (MTB) da Cidade de Trindade (GO). Revista Vita et Sanitas, Trindade (GO), 10(1), 22-37.

Schiefele, U. (2013). Response to Engeser (2012): On the nature of the flow experience. Psychol Rep: Mental Phys Health, 112, 529-532.

Seifert, T. \& Hedderson, C. (2010). Intrinsic Motivation and Flow in Skateboarding: An Ethnographic Study. Journal Happiness Studies, 11, 277-292.

Stebbins, R. (2010). Flow in serious leisure: Nature and prevalence. Leisure Studies. Assoc Newsl, 87, 21-23.

Swann, C., Piggott, D., Schweickle, M., \& Vella, S. (2018). A Review of Scientific Progress in Flow in Sport and Exercise: Normal Science, Crisis, and a Progressive Shift. Journal of Applied Sport Psychology, 30(3), 249-271. 


\title{
Avaliação de Percursos Pedestres e de Btt. Adaptação do Método de Información De Excursiones (MIDE)
}

\author{
Carlos Mata $^{1,2}$, Luís Carvalhinho ${ }^{1,3}$, José Ferreira $^{1}$
}

\author{
${ }^{1}$ Escola Superior de Desporto de Rio Maior - Instituto Politécnico de Santarém (ESDRM-IPS) \\ ${ }^{2}$ Centro de Investigação em Qualidade de Vida (CIEQV) \\ ${ }^{3}$ Centro de Investigação, Desenvolvimento e Inovação em Turismo (CITUR)
}

\begin{abstract}
Palavras-chave Avaliação de Rotas; Percursos Pedestres; Bicicleta todo Terreno (BTT)

\section{RESUMO:}

O objetivo deste estudo foi, numa primeira fase, traduzir e adaptar o método de informação de percursos (MIDE), e numa segunda fase, verificar a fiabilidade e consistência dos instrumentos para as vertentes de Pedestrianismo e BTT. Efetuou-se a tradução e análise semântica do "MIDE" para a língua portuguesa, tendo ajustado também o constructo das questões e a necessária adaptação à realidade portuguesa (Validade Prática e Validade de Construção). Em seguida realizou-se uma reunião de peritagem (expertise), com o objetivo de validar a adequação e a clareza do conteúdo específico das modalidades (Validade de Conteúdo e Validade Aparente). Depois desta fase, testaram-se os instrumentos em condições reais, por Especialistas em BTT $(n=3)$ masculinos, com idade média de 50,33 $\pm 11,24$ anos e nível de experiência de 4,33 $\pm 0,57$, numa e Especialistas em Pedestrianismo $(n=5)$ masculinos, com idade média de 36,20 $\pm 12,07$ anos e com nível de experiência de 4,60 $\pm 0,54$ numa escala de Likert (1 a 5), efetuando um pequeno estudo exploratório, no "terreno". 0 campo de aplicação foi na "Grande Rota do Carso (Oeste)", composta por oito (8) etapas Pedestres e duas (2) de BTT. Os dados foram recolhidos e analisados de forma a obter a versão final do instrumento, para os PP e para o BTT. Assim, parece-nos razoável afirmar que este instrumento poderá ser utilizado, com confiança, na caracterização de percursos pedestres e de BTT, constituindo-se como uma importante ferramenta para apoiar os técnicos e os praticantes de Pedestrianismo e de BTT.

\footnotetext{
Keywords

Route Evaluation;

Hiking Trails;

Mountain Bike

\author{
Assessment of Hiking and Mountain Bike Trails. Adaptation of the "Método de \\ Información De Excursiones (MIDE)
}

ABSTRACT:

The objective of this study was, in a first step, to translate and adapt the "Método de Información De Excursiones (MIDE)", and in a second step, to verify the reliability and consistency of the instruments for the aspects of Hiking and Mountain Bike (MB). The semantic translation and analysis of the "MIDE" was carried out into the Portuguese language, having also adjusted the construct of the questions and the necessary adaptation to the Portuguese reality (Practical Validity and Construction Validity). Then, an expert meeting was held, in order to validate the adequacy and clarity of the specific content of the modalities (Content Validity and Apparent Validity). After this step, the instruments were tested in real conditions, by male MB specialists $(n=3)$, with an average age of $50.33 \pm 11.24$ years and an experience level of $4.33 \pm 0.57$, in a male and Hiking specialist $(n=5)$, aged average of $36.20 \pm 12.07$ years and with an experience level of $4.60 \pm 0.54$ on a Likert scale ( 1 to 5 ), carrying out a small exploratory study, in the "field". The field of application was in the "Carso Route (West)", composed of eight (8) Hiking Trails and two (2) of MB. The data were collected and analyzed in order to obtain the final version of the instrument, for Hiking and MB. Thus, it seems reasonable to say that this instrument can be used, with confidence, in the characterization of Hiking and MB Trails, constituting itself as an important tool to support the monitors and practitioners of these activities.
} 


\section{Avaliação de percursos pedestres e de btt. Adaptação do Método de Información De Excursiones (MIDE)}

Torna-se cada vez mais comum, a procura de atividades e desportos associados à natureza e aventura por parte dos turistas e visitantes (Carvalhinho, Sequeira, Fernandes \& Rodrigues, 2010).

O Pedestrianismo é uma modalidade que consiste em percorrer distâncias a pé, por trilhos sinalizados, permitindo uma maior envolvência e contacto próximo com a paisagem e com as características dos locais de passagem, como a sua cultura, as pessoas e tradições (Carvalho, 2009). A Federação de Campismo e Montanhismo de Portugal (FCMP), entidade que tutela, acrescenta ainda que o pedestrianismo é multifacetado e associado às áreas do turismo e do ambiente. Quando associada a percursos sinalizados, não carece de conhecimentos de cartografia nem de orientação especiais, sendo por isso, acessível a qualquer utilizador (Brandão, 2012). O BTT (Bicicleta Todo o Terreno) é uma modalidade tutelada pela Federação de Ciclismo de Portugal (FCP) e que, tal como o nome indica, consiste em percorrer trilhos e caminhos, de preferência em terra batida, com o auxílio de uma bicicleta adaptada para esse tipo de terrenos e condições. Esta é uma modalidade, assim como o pedestrianismo, bastante associada ao contacto com a natureza, e com o contexto do lazer, no entanto, também acarreta uma vertente associada ao desafio mental, exercício físico e divertimento (White, Waskey, Brodehl, \& Foti, 2006; Newsome \& Davies, 2009). No que refere ao desenvolvimento, e derivado às mudanças da sociedade, verifica-se uma procura pelas atividades recreacionais em contacto com a natureza (Bell, Tyrväinen, Sievänen, Pröbstl, \& Simpson 2007), sendo caracterizadas por possuírem um potencial de educação ambiental (Lee, 2011) e de promoção dos estilos de vida saudáveis (Rodrigues, Kastenholz, \& Rodrigues, 2010).

A classificação dos trilhos pode dar-se de acordo com a sua função, informações quanto à sua forma, grau de dificuldade, recursos usados na interpretação ambiental, e quanto à sua extensão (Braga, 2007). Para uma avaliação mais completa, podemos complementar esta caracterização inserindo informações sobre aptidão, segundo critérios de segurança e vulnerabilidade, intensidade de erosão, posição do relevo, grau de dificuldade e marcação do percurso (Ventura, Queiroz, Resendes, Marquet, \& Melo, 2010). Em vários locais de Portugal, já começam a ser utilizadas ferramentas como o sistema "Método de Información de Excursiones" (MIDE), em percursos homologados, de forma a obter alguma informação relativa ao tipo de terreno, ao esforço exigido, à adversidade do meio e à dificuldade do percurso. Noutra perspetiva, a monitorização e avaliação da manutenção da qualidade e segurança dos percursos, através da caracterização da sua utilização e de observação direta de situações anómalas, podem contribuir para melhorar a segurança e orientação dos praticantes (Brandão, 2012).

Os autores, Carvalhinho e Rosa (2013), referenciam a qualidade como um modo de obtenção do máximo potencial dos percursos, sendo que essa qualidade pode existir em formato de informação, sendo este instrumento um método de informar e avaliação em relação aos pormenores dos percursos, podendo resultar certamente no aumento da qualidade e potencial do pedestrianismo e BTT em Portugal.

A exposição a riscos nos percursos de pedestrianismo (PP) e BTT são reconhecidos e podem ocorrer de forma natural ou por falhas humanas, como nos atropelamentos, desorientação por ocultação de marcas e sinalização (Brandão, 2012). Por sua vez, Mata e Carvalhinho (2020) na sua revisão sistemática sobre segurança e gestão do risco no desporto natureza, realçaram que na investigação atual existe uma preocupação em analisar e compreender a segurança percecionada pelos seus praticantes e técnicos.

Surge assim a necessidade pelo conhecimento, informação e avaliação sistemática dos percursos no sentido de garantir a qualidade das condições de prática destes locais. Com a construção de um instrumento de informação e avaliação, procura-se caracterizar os percursos para apoiar os praticantes e técnicos nas suas opções e intervenções, na diminuição do risco e da probabilidade de acidentes. Assim, o objetivo deste estudo, foi numa primeira fase, traduzir e adaptar o MIDE, e numa segunda fase, verificar a fiabilidade e consistência do instrumento de medida para as vertentes de Pedestrianismo e BTT.

\section{Método}

O propósito deste estudo, consistiu em adaptar para a versão portuguesa, o "Método de Información De Excursiones" (MIDE), tornando-se importante nesta secção, descrever os passos utilizados para a adaptação e validação do instrumento original (versão espanhola). Assim, com base em Hill e Hill (2000), e Thomas e Nelson (1990), visando a sua aplicação na realidade portuguesa, procedeu-se do seguinte modo:

\section{Instrumento de pesquisa}

O MIDE (versão original), é um sistema de comunicação entre excursionistas, para avaliar e expressar as exigências técnicas dos percursos. $\mathrm{O}$ seu objetivo é uniformizar as apreciações sobre a

dificuldade dos percursos para permitir a cada participante uma melhor seleção. Este instrumento foi concebido como uma ferramenta para a prevenção de acidentes em percursos no meio natural, sendo recomendado por diversas entidades espanholas, nomeadamente, Federación Española de Deportes de Montaña y Escalada (FEDME), 
Federación Aragonesa de Montañismo (FAM), Protección Civil del Gobierno de Aragón, entre outras (Montaña Segura, 2020).

Tabela 1. Síntese de etapas de adaptação, tradução e aplicação do Instrumento.

\begin{tabular}{ll}
\hline & Etapas para a adaptação e tradução para a versão Portuguesa do instrumento (MIDE) \\
\hline Etapa 1 & Tradução para Português da versão Original (Espanhol) \\
Etapa 2 & Tradução e Análise semântica / $1^{\text {a }}$ Versão - PP \\
Etapa 3 & Validação prática e Validade de construção / $2^{\mathrm{a}}$ versão - PP \\
Etapa 4 & Validação de construção / $1^{\mathrm{a}}$ versão - BTT \\
Etapa 5 & Validação de Conteúdo / $2^{\mathrm{a}}$ versão - BTT \\
Etapa 6 & Validação Aparente / $3^{\mathrm{a}}$ versão - PP e $3^{\mathrm{o}}$ versão - BTT \\
Etapa 7 & Aplicação-piloto (Estudo exploratório) no contexto português \\
\hline
\end{tabular}

Assim, o primeiro passo consistiu em traduzir o instrumento (documento) para a língua portuguesa. Este trabalho foi efetuado pelo grupo de autores, com auxílio de dicionários e em discussão simultânea. Obteve-se aqui, a versão portuguesa, para a vertente dos Percursos Pedestres (PP), servindo esta de base para a vertente de BTT (Tradução e Análise Semântica / $1^{\mathrm{a}}$ versão - PP).

Em seguida, procedeu-se à pesquisa de alguns estudos efetuados com metodologias semelhantes (Carvalhinho, 2006; Carvalhinho, Rosa, \& Gomes, 2015; Carvalhinho, Rodrigues, \& Rosa, 2015), confrontando algumas das variáveis utilizadas, devido à proximidade dos respetivos contextos de prática. Permitiu-se ajustar o constructo das questões e a necessária adaptação à realidade portuguesa, uma vez que existem algumas diferenças ao nível desses contextos, nomeadamente, nas condições do meio natural (Validade Prática e Validade de Construção / $2^{\mathrm{a}}$ versão - PP).

Considerando o trabalho anterior, os autores adaptaram e construíram o instrumento para a vertente BTT, tendo em conta as características da prática desta modalidade (Validade de Construção / $1^{\mathrm{a}}$ versão BTT). O passo seguinte consistiu em realizar uma reunião de peritagem (expertise) de BTT, com o objetivo de validar a adequação e a clareza do conteúdo específico da modalidade, reunindo contributos para obter uma versão retificada (Validade de Conteúdo / 2 ${ }^{\mathrm{a}}$ versão - BTT). $\mathrm{O}$ processo de validação destes dois instrumentos (vertentes PP e BTT), para aplicação à realidade nacional, implicou recorrer ao contributo individualizado de cinco profissionais (Professores, Técnicos e Investigadores da área do Desporto), distribuídos pelas duas vertentes em estudo, de modo a perseguir os seguintes objetivos: i) adequar a sua aplicabilidade, clareza e objetividade; ii) Filtrar a terminologia utilizada; iii) Facilitar as respostas, evitando perguntas múltiplas e neutras; iv) Possibilitar respostas alternativas (gerais) suficientes. No fim desta fase obtiveram-se novas versões (Validade Aparente / $3^{\mathrm{a}}$ versão - PP e $3^{\mathrm{a}}$ versão BTT).

Despois desta fase, testaram-se os instrumentos em condições reais, i.e., efetuou-se um pequeno estudo exploratório, no "terreno", com o objetivo de verificar a fiabilidade e a consistência dos instrumentos. Apesar do instrumento original (em versão espanhola) ser criado no ano de 2002, colocou-se a necessidade de estabelecer o seu grau de confiança para a realidade portuguesa, ou seja, verificar a sua consistência. De acordo com Thomas e Nelson (1990) e Hill e Hill (2000), existem várias metodologias para estimar a fiabilidade de um instrumento, nomeadamente, a consistência em termos de estabilidade temporal. Neste caso, realizouse um estudo exploratório (aplicação-piloto) no contexto português, tendo em conta o seguinte: Os instrumentos "Método de Informação e Avaliação para Percursos Pedestres" (MIA PP) e "Método de Informação e Avaliação para BTT” (MIA_BTT).

$\mathrm{Na}$ tabela 1, verifica-se que a amostra selecionada respeitou o mesmo perfil pessoal e socioprofissional dos futuros destinatários, ou seja, os profissionais destas modalidades. 
Tabela 2. Caracterização dos participantes

\begin{tabular}{lcccc}
\hline Especialistas (Total=8) & Género & $\begin{array}{c}\text { Idade } \\
(\mathbf{M} \pm \mathbf{D P})\end{array}$ & $\begin{array}{c}\text { Nível de } \\
\text { Experiência }\end{array}$ & $\begin{array}{c}\text { Nível de Condição } \\
\text { Física }\end{array}$ \\
\hline BTT $(\mathrm{n}=3)$ & $100 \%$ Masc & $50.33 \pm 11.24$ & $4.33 \pm 0.57$ & $3.67 \pm 0.57$ \\
Pedestrianismo $(\mathrm{n}=5)$ & $100 \%$ Masc & $36.20 \pm 12.07$ & $4.60 \pm 0.54$ & $4.20 \pm 0.447$ \\
\hline
\end{tabular}

Legenda: a) Género (valor absoluto); b) Idade (Média e DP); c) Nível de Experiência e Nível de Condição Física (escala de Likert de 1 a 5)

O campo de aplicação deste estudo exploratório foi a "Grande Rota do Carso (Oeste)", composta por oito etapas Pedestres e duas de BTT. Os dados e os comentários foram recolhidos e analisados pela equipa de investigação, no sentido de poder ajustar, ainda, alguns detalhes e melhorias finais ( $\left(4^{\mathrm{a}}\right.$ versão PP e $4^{\mathrm{a}}$ versão - BTT).

A estrutura geral é idêntica nas duas modalidades, sendo composta pelas seguintes dimensões e variáveis: (i) Perfil Pessoal e Socioprofissional: Idade; Género; Nível de Experiência; Nível de Condição Física; Profíssão; (ii) Informação sobre o Percurso: Nome do Percurso; Data; Estações do ano; Tipo de Percurso; Distância; Desnível Acumulado Ascendente; Desnível Acumulado Descendente; Duração; Tipo de Piso; Painel Informativo; (iii) Meio: Fatores de Risco; (iv) Itinerário: Marcação e Sinalização; v) Percurso: Difículdade do Percurso; (vi) Esforço: Nível de Esforço; Carga Externa; (vii) Dificuldade Técnica: Vegetação (Densidade); Vertentes/Rampas; Progressão no Terreno; Obstáculos.

As escalas de resposta utilizadas foram variadas, desde respostas nominais, de ocorrências múltiplas, de apreciação, de opção em alternativa e de perceção. Para finalizar este capítulo, identificaramse algumas limitações nesta pesquisa, como por exemplo, a dimensão do grupo de participação (amostra) final, utilizada no estudo exploratório.
Seria interessante mobilizar um maior número de profissionais para testar os instrumentos e recolher um maior número de dados, permitindo dessa forma, analisar com outra profundidade, a fiabilidade e a consistência interna do instrumento (p.e. "TesteReteste", para verificar a estabilidade temporal do mesmo). A situação de Pandemia da COVID 19, nesta fase de produção do manuscrito, não permitiu implementar estes procedimentos, adiando para outro momento, a consecução deste objetivo.

Considerando a natureza qualitativa do estudo, foi utilizada a análise descritiva, utilizando valores absolutos, valores relativos, parâmetros de tendência central (média), e parâmetros de dispersão (DP, valores mínimos e máximos).

\section{Resultados}

Os resultados apresentados nesta seção, correspondem aos dados recolhidos no estudo exploratório efetuado nas vertentes pedestre e BTT e que correspondem às diversas variáveis que compõem as questões do instrumento de medida (questionário final) e que serão apresentadas nas tabelas 2 a 10. Assim, considerando as duas modalidades e o número elevado de variáveis, optou-se por analisar uma modalidade de cada vez através do "MIA_PP" e "MIA_BTT", organizando por sua vez, a apresentação dos dados em tabelas por grupos (dimensões) de variáveis. 
Tabela 3. MIA_PP - Informação do Percurso

\begin{tabular}{|c|c|c|c|c|c|c|c|c|}
\hline $\begin{array}{c}\text { Informação Percurso } \\
\text { (GRC - Etapas) }\end{array}$ & E1 & $\mathbf{E 2}$ & E3 & $\mathbf{E 4}$ & E5 & E6 & E7 & E8 \\
\hline Nome do Percurso & GRC E1 & GRC E2 & GRC E3 & GRC E4 & GRC E5 & GRC E6 & GRC E7 & GRC E8 \\
\hline Partida & Rio Maior & Chãos & Arrimal & Porto Mós & Pia Urso & Alvados & Alviela & Alcanede \\
\hline Chegada & Chãos & Arrimal & Porto Mós & Pia Urso & Alvados & Alviela & Alcanede & Rio Maior \\
\hline Tipo de Percurso & Travessia & Travessia & Travessia & Travessia & Travessia & Travessia & Travessia & Travessia \\
\hline Distância (m) & 12060 & 15120 & 21940 & 15183 & 13410 & 20400 & 18940 & 18110 \\
\hline Desn. Acum. Ascend. (m) & 323 & 423 & 347 & 530 & 125 & 380 & 319 & 349 \\
\hline Desn. Acum. Descenc. (m) & 105 & 385 & 549 & 210 & 316 & 576 & 304 & 351 \\
\hline Duração (h) & 3 a $5 \mathrm{~h}$ & 3 a $5 \mathrm{~h}$ & 5 a $7 \mathrm{~h}$ & 3 a $5 \mathrm{~h}$ & 3 a $5 \mathrm{~h}$ & 5 a $7 \mathrm{~h}$ & 3 a $5 \mathrm{~h}$ & 3 a $5 \mathrm{~h}$ \\
\hline Painel Informativo & Digital & Digital & Digital & Digital & Digital & Digital & Digital & Digital \\
\hline \multicolumn{9}{|l|}{ Estação do ano } \\
\hline Primavera & $\checkmark$ & $\checkmark$ & $\checkmark$ & $\checkmark$ & $\checkmark$ & $\checkmark$ & $\checkmark$ & $\checkmark$ \\
\hline Verão & $\checkmark$ & & $\checkmark$ & $\checkmark$ & $\checkmark$ & $\checkmark$ & $\checkmark$ & $\checkmark$ \\
\hline Outono & $\checkmark$ & $\checkmark$ & $\checkmark$ & $\checkmark$ & $\checkmark$ & $\checkmark$ & $\checkmark$ & $\checkmark$ \\
\hline Inverno & $\checkmark$ & $\checkmark$ & & $\checkmark$ & $\checkmark$ & $\checkmark$ & $\checkmark$ & $\checkmark$ \\
\hline \multicolumn{9}{|l|}{ Tipo de Piso } \\
\hline Estrada Asfaltada & $\checkmark$ & $\checkmark$ & $\checkmark$ & $\checkmark$ & $\checkmark$ & $\checkmark$ & $\checkmark$ & $\checkmark$ \\
\hline Estrada de Terra Batida & $\checkmark$ & $\checkmark$ & $\checkmark$ & $\checkmark$ & $\checkmark$ & $\checkmark$ & $\checkmark$ & $\checkmark$ \\
\hline Caminhos Irregulares & $\checkmark$ & $\checkmark$ & & $\checkmark$ & $\checkmark$ & $\checkmark$ & & $\checkmark$ \\
\hline Trilho (single track) & & $\checkmark$ & $\checkmark$ & $\checkmark$ & $\checkmark$ & $\checkmark$ & $\checkmark$ & \\
\hline
\end{tabular}

Na vertente pedestre, podemos verificar através da tabela 3, que o percurso da "Grande Rota do Carso" (GRC) é composto por 8 etapas entre os $12060 \mathrm{~m} \mathrm{e}$ os $21940 \mathrm{~m}$, totalizando cerca de $135000 \mathrm{~m}$ (aproximadamente). O desnível acumulado (positivo) varia entre os $125 \mathrm{~m}$ e os $530 \mathrm{~m}$, e a duração entre as $3 \mathrm{~h}$ e as $7 \mathrm{~h}$. Todas as etapas estão disponíveis em formato digital, sendo recomendado preferencialmente para as estações da primavera e outono. O tipo de piso apresenta-se com características mistas, ou seja, inclui troços de estrada asfaltada e de terra batida, caminhos irregulares e single tracks. A etapa 1 de "Rio Maior / Chãos" apresenta a menor distância (12060m) e duração (3h). Por outro lado, a etapa 3 de "Arrimal / Porto de Mós" apresenta a maior distância $(21940 \mathrm{~m})$ e a maior duração (7h). A etapa 4 de "Porto de Mós à Pia de Urso" é a que apresenta maior desnível acumulado positivo $(530 \mathrm{~m})$, sendo a etapa 5 de "Pia do Urso a Alvados", a etapa que apresenta menor desnível acumulado positivo $(125 \mathrm{~m})$.

Tabela 4. MIA_PP - Meio e Fatores de Risco

\begin{tabular}{|c|c|c|c|c|c|c|c|c|}
\hline Meio e Fatores de Risco (Etapas) & E1 & E2 & $\mathbf{E 3}$ & E4 & E5 & E6 & E7 & E8 \\
\hline Possibilidade de escorregar ou derrapar levando a uma queda & $\checkmark$ & $\checkmark$ & $\checkmark$ & $\checkmark$ & $\checkmark$ & $\checkmark$ & $\checkmark$ & $\checkmark$ \\
\hline (...) possiveis derrocadas causadas pela passagem de grupos ou outros & & & & & & $\checkmark$ & & \\
\hline Passagem de rios ou ribeiros sem ponte & & & & & & & & $\checkmark$ \\
\hline Passagem por locais isolados, até $30 \mathrm{~min}$. de um local habitado & $\checkmark$ & $\checkmark$ & $\checkmark$ & $\checkmark$ & $\checkmark$ & $\checkmark$ & $\checkmark$ & $\checkmark$ \\
\hline Passagem por locais isolados, até 30min. sem rede telemóvel & & $\checkmark$ & $\checkmark$ & $\checkmark$ & $\checkmark$ & $\checkmark$ & $\checkmark$ & $\checkmark$ \\
\hline $\begin{array}{l}\text { (...) temperatura desça dos } 5^{\circ} \mathrm{C} \text { e que a humidade relativa suba os } 90 \% \\
\text { Probabilidade de (...) terminar a menos de } 1 \text { hora antes do anoitecer }\end{array}$ & $\checkmark$ & & $\checkmark$ & & $\checkmark$ & $\checkmark$ & & \\
\hline
\end{tabular}

Através da tabela 4, verifica-se que no conjunto das oito etapas e considerando o meio e os fatores de risco, a possibilidade de escorregar levando a uma queda foi assinalada em todas as etapas, assim como a passagem por locais isolados, até 30 minutos de um local habitado. No caso da passagem por locais isolados, até 30 minutos sem rede telemóvel, apenas não foi selecionada na etapa 1 de "Rio Maior a Chãos". Salientamos que na etapa 6 de "Alvados ao Alviela" podem existir possíveis derrocadas 
causadas pela passagem de grupos ou outros, e que na etapa 8 de "Alcanede a Rio Maior" é mencionada a passagem de rios ou ribeiros sem ponte. $\mathrm{Na}$ etapa
6 de "Alvados ao Alviela" verifica-se a probabilidade de terminar a etapa a menos de 1 hora antes do anoitecer.

Tabela 5. MIA_PP - Itinerário, Marcação/Sinalética e Dificuldade do Percurso

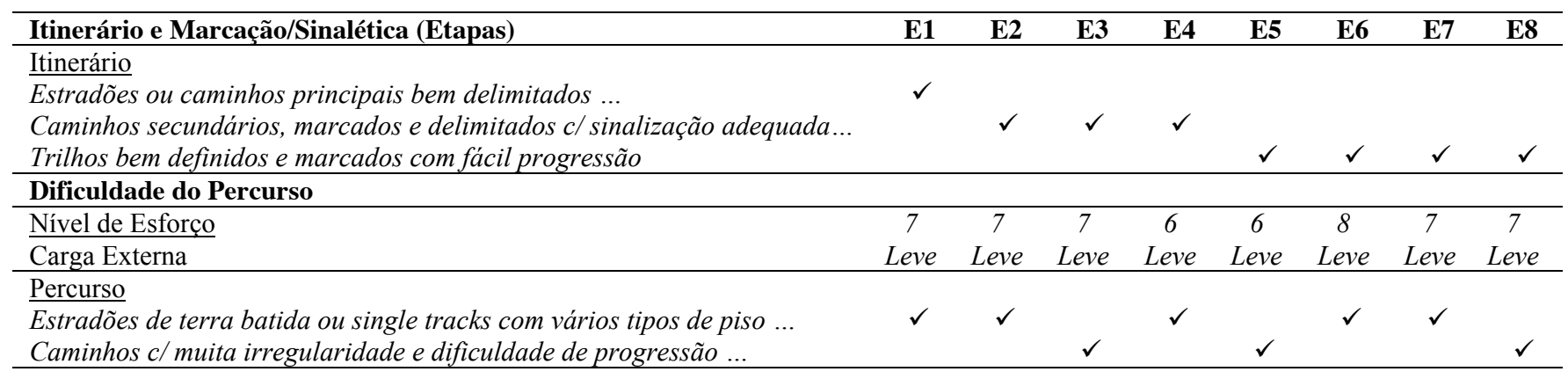

Considerando a tabela 5 , podemos verificar que o itinerário dominante vai progredindo ao longo das 8 etapas (GRC), passando de estradões ou caminhos principais bem delineados (etapa 1), para caminhos secundários (etapa 2, 3 e 4) terminando em trilhos bem definidos e marcados com fácil progressão.

No que refere a dificuldade do percurso, o nível de esforço referenciado através da "Escala de Borg" (Borg, 1998), obteve uma média que se situa na intensidade 7, com à exceção das etapas 4 de "Porto de Mós à Pia do Urso" e etapa 5 da "Pia do Urso a Alvados" com uma intensidade de 6 e a Etapa 6 de "Alvados ao Alviela" considerada a mais intensa com 8. No conjunto das etapas, a carga externa necessária é considerada leve num percurso dominante que varia entre os estradões de terra batida ou singles tracks com vários tipos de piso (etapas 1, 2, 4, 6 e 7) e os caminhos com muita irregularidade e dificuldade de progressão, nas restantes etapas.

$\mathrm{Na}$ tabela 6, considerando a dificuldade técnica, podemos verificar que a vegetação

é considerada pouco densa à exceção da etapa 2 de "Chãos ao Arrimal" que foi considerada vegetação moderada, com vertentes e rampas de inclinação assinalável e/ou dificuldade de aderência (10\%) que apenas não foi assinalada nas etapas 7 do "Alviela a Alcanede" e etapa 8 de "Alcanede a Rio Maior".

As etapas 1, 2, 4 e 7 têm uma progressão no terreno fácil, já as etapas $3,5,6$ e 8 são consideradas de progressão moderada relativamente aos obstáculos e transposições. As etapas caracterizam-se por transposição fácil com a exceção da etapa 5 da "Pia do Urso a Alvados" que se caracteriza por transposição moderada.

Tabela 6. MIA_PP - Dificuldade Técnica

\begin{tabular}{|c|c|c|c|c|c|c|c|c|}
\hline Dificuldade Técnica (Etapas) & E1 & E2 & $\mathbf{E 3}$ & E4 & E5 & E6 & E7 & E8 \\
\hline$\underline{\text { Vegetação }}$ & & & & & & & & \\
\hline $\begin{array}{l}\text { Vegetação Pouco Densa } \\
\text { Vegetação Moderada }\end{array}$ & $\checkmark$ & $\checkmark$ & $\checkmark$ & $\checkmark$ & $\checkmark$ & $\checkmark$ & $\checkmark$ & $\checkmark$ \\
\hline Vertentes e Rampas & & & & & & & & \\
\hline $\begin{array}{l}\text { Pouca Inclinação elou sem dificuldade de aderência (5\%) } \\
\text { Com inclinaçâo assinalável elou dificuldade de aderência (10\%) }\end{array}$ & $\checkmark$ & $\checkmark$ & $\checkmark$ & $\checkmark$ & $\checkmark$ & $\checkmark$ & $\checkmark$ & $\checkmark$ \\
\hline $\begin{array}{l}\text { Progressão no terreno } \\
\text { Progressão Fácil (ex.: terra Batida /piso firme) }\end{array}$ & $\checkmark$ & $\checkmark$ & & $\checkmark$ & & & $\checkmark$ & \\
\hline Progressão Moderada (ex.: single tracks fáceis) & & & $\checkmark$ & & $\checkmark$ & $\checkmark$ & & $\checkmark$ \\
\hline $\begin{array}{l}\text { Obstáculos/Transposições } \\
\text { Transposição Fácil (ex.: buracos, valas ou raízes de pequenas dimensões) } \\
\text { Transposição Moderada (ex.: buracos, valas ou raizes de média dimensão) }\end{array}$ & $\checkmark$ & $\checkmark$ & $\checkmark$ & $\checkmark$ & $\checkmark$ & $\checkmark$ & $\checkmark$ & $\checkmark$ \\
\hline
\end{tabular}

Na vertente de BTT, podemos verificar através da tabela 7, que o percurso da "Grande Rota do Carso" (GRC) é composto pelas etapas 1 e 2 com $60050 \mathrm{~m}$ e $66304 \mathrm{~m}$ respetivamente, resultando num total de $126354 \mathrm{~m}$. O desnível acumulado (positivo) é superior na etapa 1 de "Rio Maior à Pia do Urso", sendo o desnível acumulado (negativo) superior na etapa 2 da "Pia do Urso a Rio Maior". As duas etapas têm a duração entre as $3 \mathrm{~h}$ e as $5 \mathrm{~h}$. Todas as etapas estão disponíveis em formato digital, sendo recomendas, preferencialmente para as estações da primavera e outono. O tipo de piso apresenta-se com características mistas, ou seja, inclui troços de 
estrada asfaltada e de terra batida, caminhos irregulares e single tracks.

Tabela 7. MIA_BTT - Informação do Percurso

um local habitado. A Exposição do itinerário a possíveis derrocadas causadas pela passagem de

\begin{tabular}{lcc}
\hline Informação Percurso (Etapas) & E1 & E2 \\
\hline Nome do Percurso & GRC E1 & GRC E2 \\
Tipo de Percurso & Travessia & Travessia \\
Distância & 60050 & 66304 \\
Desnível Acumulado Ascendente & 1455 & 1089 \\
Desnível Acumulado Descendente & 1081 & 1462 \\
Duração & 3 a 5 h & 3 a $5 \mathrm{~h}$ \\
Painel Informativo & Digital & Digital \\
\hline Estação do ano & & \\
\hline Primavera & $\checkmark$ & $\checkmark$ \\
Outono & $\checkmark$ & $\checkmark$ \\
Inverno & & $\checkmark$ \\
\hline Tipo de Piso & & \\
\hline Estrada Asfaltada & $\checkmark$ & $\checkmark$ \\
Estrada de Terra Batida & $\checkmark$ & $\checkmark$ \\
Caminhos Irregulares & $\checkmark$ & $\checkmark$ \\
Trilho (single track) & & $\checkmark$ \\
\hline
\end{tabular}

Através da tabela 8, considerando o meio e os fatores de risco, a etapa 2 da "Pia do Urso a Rio Maior" regista o maior número de fatores de risco, incluindo a passagem por rios ou ribeiras sem ponte e passagem por locais isolados, até 30 minutos de grupos, a possibilidade de escorregar ou derrapar levando a uma queda e a existência de troços ou segmentos, onde é necessário levar a bicicleta à mão, foram fatores de risco assinalados nas duas etapas.

Tabela 8. MIA_BTT - Meio e Fatores de Risco

\begin{tabular}{lcc}
\hline Meio e Fatores de Risco & $\mathbf{1}$ & $\mathbf{2}$ \\
\hline Exposição do itinerário a possíveis derrocadas causadas pela passagem de grupos... & $\checkmark$ & $\checkmark$ \\
Possibilidade de escorregar ou derrapar levando a uma queda & $\checkmark$ & $\checkmark$ \\
Existência de troços ou segmentos, onde é necessário levar a bicicleta à mão & $\checkmark$ & $\checkmark$ \\
Passagem de rios ou ribeiros sem ponte & $\checkmark$ \\
Passagem por locais isolados, até 30minutos de um local habitado & $\checkmark$ \\
Passagem por locais isolados, até 30minutos sem rede telemóvel & $\checkmark$ \\
\hline
\end{tabular}

Considerando a tabela 9, podemos verificar que o itinerário dominante são caminhos secundários, com necessária atenção nos cruzamentos com outros caminhos.

Em relação à dificuldade do Percurso, a etapa 1 de "Rio Maior à Pia do Urso" apresenta uma intensidade de esforço de 7 e na etapa 2 da "Pia do Urso a Rio Maior", uma intensidade de 6, com uma carga externa (bagagem + bicicleta) considerada moderada nas duas etapas. Quanto ao percurso na etapa 1, foi referido como mais prevalente, os estradões de terra batida ou single tracks com vários pisos e pouca irregularidade. $\mathrm{Na}$ etapa 2 assinalaram-se os caminhos com muita irregularidade, com dificuldade de progressão e moderada inclinação. 
Tabela 9. MIA_BTT - Itinerário, Marcação/Sinalética e Dificuldade do Percurso

\begin{tabular}{|c|c|c|}
\hline Itinerário e Marcação/Sinalética & 1 & 2 \\
\hline Itinerário & & \\
\hline Caminhos secundários ... Necessária atenção nos cruzamentos com outros caminhos & $\checkmark$ & $\checkmark$ \\
\hline Dificuldade do Percurso & & \\
\hline $\begin{array}{l}\text { Nível de Esforço } \\
\text { Carga Externa }\end{array}$ & $\begin{array}{c}7 \\
\text { Moderada } \\
\end{array}$ & $\begin{array}{c}6 \\
\text { Moderada } \\
\end{array}$ \\
\hline $\begin{array}{l}\text { Percurso } \\
\text { Estradões de terra batida ou single tracks com vários tipos de piso, pouca irregularidade ... } \\
\text { Caminhos c/ muita irregularidade, com dificuldade de progressão e moderada inclinação }\end{array}$ & $\checkmark$ & $\checkmark$ \\
\hline
\end{tabular}

Através da tabela 10 , verifica-se que a dificuldade técnica, nomeadamente na progressão no terreno, difere entre a etapa 1 , com registo de progressão fácil e a etapa 2 , com uma progressão moderada. As duas etapas apresentam uma vegetação pouco densa, com vertentes e rampas de inclinação assinalável e/ou dificuldade de aderência (10\%).

Os obstáculos e transposições foram indicados como transposição fácil na etapa 1, passando para progressão moderada na etapa 2 .

Tabela 10. MIA_BTT - Dificuldade Técnica

\begin{tabular}{lc}
\hline Dificuldade Técnica & $\mathbf{1}$ \\
\hline Progressão no terreno & $\mathbf{2}$ \\
\hline $\begin{array}{l}\text { Progressão Fácil (ex.: terra Batida /piso firme) } \\
\text { Progressão Moderada (ex.: single tracks fáceis) }\end{array}$ & $\checkmark$ \\
\hline Vegetação & $\checkmark$ \\
\hline Vegetação Pouco Densa & $\checkmark$ \\
\hline Vertentes e Rampas & $\checkmark$ \\
\hline Com inclinação assinalável e/ou dificuldade de aderência (10\%) & $\checkmark$ \\
\hline Obstáculos/Transposições & $\checkmark$ \\
Transposição Fácil (ex.: buracos, valas ou raizes de pequenas dimensões) & $\checkmark$ \\
\hline Transposição Moderada (ex.: buracos, valas ou raizes de média dimensão) & $\checkmark$ \\
\hline
\end{tabular}

\section{Discussão}

Os objetivos propostos passaram por traduzir, adaptar e verificar a consistência do "Método de Informação e Avaliação de Percursos Pedestres" (MIA_PP) e do "Método de Informação e Avaliação de Percursos de BTT (MIA_BTT)". Através dos resultados verificouse que este instrumento serve o propósito como sistema de comunicação para praticantes e técnicos, não existindo dificuldade na sua interpretação e utilização, como podemos verificar através da caracterização realizada à "Grande Rota do Carso (Oeste)", nas versões Pedestre e BTT. Ao longo das dimensões e variáveis do instrumento, os nossos especialistas mantiveram a consistência entre si, reforçando a organização, clareza e objetividade do respetivo instrumento.

Também de acordo com Brandão (2012), a obtenção de informações e avaliações objetivas e reais, expressam a pertinência deste tipo de instrumentos, que segundo (Cessford, 1995), existem diversos perfis de praticantes de pedestrianismo e de BTT, havendo uma relação com os anos de prática, condição física, equipamento adequado $\mathrm{e}$ heterogeneidade dos grupos de praticantes. Desta forma e concordando com Symmonds, Hammitt, e Quisenberry (2000), existe a necessidade de saber selecionar percursos, tendo em conta as suas características, podendo este estudo apresentar uma resposta útil, através da informação e avaliação que é possível recolher. Esta informação reforça a relevância dos estudos de Rodrigues et al. (2010) e Dorwart, Moore e Leung (2009), quando se afirma que é necessário efetuar uma adequada caracterização e avaliação, a fim de informar os praticantes acerca do que poderão encontrar nos respetivos percursos. Este método de informação e avaliação poderá também potenciar a qualidade através de processos de gestão e monitorização, fundamentados, como sugerem Rosa, Almeida e Carvalhinho (2011a) e Rosa et al. (2011b). De acordo com Carvalhinho e Rosa (2013) e também Sales (2015), contributos deste género, podem permitir aos técnicos de desporto de 
natureza, melhorar e adequar o planeamento das suas atividades, evitando insatisfações e ocorrência de acidentes, assim como referido também por Melo (2003).

\section{Conclusões}

Tendo em consideração o objetivo deste estudo, o "Método de Información De Excursiones" (MIDE), foi adaptado para a versão portuguesa, nas vertentes de Pedestrianismo e de BTT, passando a designar-se "Método de Informação e Avaliação para Percursos Pedestres" (MIA_PP) e "Método de Informação e Avaliação para BTT" (MIA_BTT).

Conclui-se que, as suas qualidades de organização, clareza e objetividade comprovam a adequação da adaptação efetuada, demonstrando que a sua estrutura factorial possui índices bastante aceitáveis de validade e de fiabilidade. Assim, parece-nos razoável afirmar que o "MIA_PP" e "MIA_BTT" poderão ser utilizados, com a confiança necessária, para a caracterização de Percursos Pedestres e de BTT, constituindo-se comos instrumentos úteis de apoio aos técnicos e praticantes de Pedestrianismo e de BTT.

\section{Referências}

Bell, S., Tyrväinen, L., Sievänen, T., Pröbstl, U., \& Simpson, M. (2007). Outdoor recreation and nature tourism: A European perspective. Living Reviews in Landscape Research, 1(2), 1-46.

Borg G. (1998) Borg's perceived exertion and pain scales. Human Kinetics.

Braga, T. (2007). Pedestrianismo e percursos pedestres. Amigos dos Açores, Ribeira Grande.

Brandão, B. (2012). Avaliação da qualidade dos percursos pedestres homologados em Portugal ( $\mathrm{PhD})$. Escola Superior de Hotelaria e Turismo do Estoril.

Carvalhinho, L (2006). Os Técnicos e as actividades de desporto de natureza. Análise da formação, funções e competências profissionais (PhD). UTAD, Vila Real.

Carvalho, P. (2009). Pedestrianismo e percursos pedestres. Cadernos de Geografia (28/29).

Carvalhinho, L., Sequeira, P., Serôdio-Fernandes, A., \& Rodrigues, J. (2010). A emergência do sector de desporto de natureza e a importância da formação. Revista Digital-Buenos Aires, 140.

Carvalhinho, L., \& Rosa, P. (2013) Avaliação dos percursos pedestres do Parque Natural das Serras de Aire e Candeeiros. VI International Tourism Congress - ESTM/Peniche.

Carvalhinho, L., Rosa, P., \& Gomes, F. (2015). The hiking trails evaluation in the Natural Park of Serras de Aire e Candeeiros, Portugal. European Journal of Tourism, Hospitality and Recreation, 6(2), 139-156
Carvalhinho, L., Rodrigues, L., \& Rosa, P. (2015). Avaliação de espaços naturais para a prática da escalada - Estudo de caso no Parque Natural das Serras de Aire e Candeeiros (PNSAC). Journal of Sport Pedagogy \& Research, 1(3), 64-73.

Cessford, G. (1995). Off road mountain biking: A profile of participants and their recreation setting and experience preferences. www.mountainbike.co.nz/politics/doc/profile/.

Dorwart, C., Moore, R., \& Leung, Y. (2009). Visitors' perceptions of a trail environment and effects on experiences: A model for nature-based recreation experiences. Leisure Sciences, 32(1), 33-54. https://doi.org/10.1080/01490400903430863

Hill, M., \& Hill, A. (2000). Investigação por Questionário. Edições Sílabo.

Lee, T. H. (2011). How recreation involvement, place attachment and conservation commitment affect environmentally responsible behavior. Journal of Sustainable Tourism, 19(7), 895-915.

https://doi.org/10.1080/09669582.2011.570345

Marinho, A. (2008). Lazer, aventura e risco: Reflexões sobre atividades realizadas na natureza. Movimento, 14(2), 181-206. https://doi.org/10.22456/19828918.5756

Mata, C., \& Carvalhinho, L. (2020). Security and risk management in outdoor sports: An exploratory systematic review. SPORT TK-Revista EuroAmericana de Ciencias del Deporte, 8(2), 59-64.

Montaña Segura (2020). Métedo de Información De Excursionistas (MIDE). Gobierno de Aragón. http://mide.montanasegura.com/

Newsome, D., \& Davies, C. (2009). A case study in estimating the area of informal trail development and associated impacts caused by mountain bike activity in John Forrest National Park, Western Australia. Journal of Ecotourism, 8(3), 237-253. https://doi.org/10.1080/14724040802538308

Rodrigues, Á., Kastenholz, E. \& Rodrigues, A. (2010). Hiking as a relevant wellness activity: Results of an exploratory study of hiking tourists in Portugal applied to a rural tourism project. Journal of Vacation Marketing, 16(4), 331-343. https://doi.org/10.1177/1356766710380886

Rosa, P., Almeida, M., \& Carvalhinho, L. (2011a). Desporto de natureza em espaços naturais: contributo para o ordenamento em áreas protegidas (Mestrado). Instituto Politécnico de Santarém: Escola Superior de Desporto de Rio Maior, Rio Maior.

Rosa, P., Almeida, M., \& Carvalhinho, L. (2011b). Gestão da recreação em áreas protegidas: Relevância dos aspectos sociais. Paper presented at the Congresso Internacional de Montanha-CIM2011, Estoril. 
Sales, M. (2015). Percursos na paisagem (PhD). Universidade de Évora.

Symmonds, M. C., Hammitt, W. E., \& Quisenberry, V. L. (2000). Managing recreational trail environments for mountain bike user preferences. Environmental Management, 25(5), 549-564. https://doi.org/10.1007/s002679910043

Thomas, J., \& Nelson, J. (1990). Research methods in physical activity. Human Kinetics.

Ventura, M. A., Queiroz, R. E., Resendes, R., Marquet, N., \& Melo, J. A. (2010). Caracterização e avaliação dos percursos pedestres da ilha de Santa Maria. XIV Expedição Científica do Departamento de Biologia Santa Maria 2009 - Rel. Com. Dep. Biol.36: 168.

White, D.D., Waskey, M.T., Brodehl, G.P., \& Foti, P.E. (2006). A comparative study on impacts to mountain bike trails in five common biophysical regions of the Southwestern US. Journal of Park and Recreation Administration, 24(2), 21-41. 